UNIVERSIDADE DE SÃO PAULO

FACULDADE DE ARQUITETURA E URBANISMO

PAULO HENRIQUE BERNARDELLI MASSABKI

\title{
Centros e museus de ciência e tecnologia
}

São Paulo

2011 


\title{
Centros e museus de ciência e tecnologia
}

\author{
Dissertação apresentada à \\ Faculdade de Arquitetura e Urbanismo da \\ Universidade de São Paulo \\ para obtenção do título de \\ Mestre em Arquitetura
}

Área de Concentração:

História e Fundamentos da

Arquitetura e do Urbanismo

Orientador: Prof. Dr.

Paulo Júlio Valentino Bruna

São Paulo

2011 
Autorizo a reprodução e divulgação total ou parcial deste trabalho, por qualquer meio convencional ou eletrônico, para fins de estudo e pesquisa, desde que citada a fonte.

Email: arqpaulo@usp.br

Massabki, Paulo Henrique Bernardelli

M414c Centros e museus de ciência e tecnologia / Paulo Henrique Bernardelli Massabki. --São Paulo, 2011.

274 p. : il.

Dissertação (Mestrado - Área de Concentração: História e Fundamentos da Arquitetura e Urbanismo) - FAUUSP.

Orientador: Paulo Júlio Valentino Bruna

1.Museus (Arquitetura) 2.Museologia I.Título

CDU 727.7 


\section{DEDICATÓRIA}

Ao meu filho João Paulo, que foi o verdadeiro estímulo para a incursão nessa jornada. 
AGRADECIMENTOS

À minha esposa Vera, por cuidar do João Paulo enquanto eu desenvolvia a pesquisa - o que não é pouca coisa!

Aos meus pais, João e Celeste, pelo exemplo e apoio permanente.

Ao Prof. Dr. Paulo Júlio Valentino Bruna, pela orientação, estímulo e pelas disciplinas ministradas.

Ao Prof. Dr. Lucio Gomes Machado, pela disciplina ministrada, pela entrevista concedida e pelos comentários sobre o trabalho.

Às Profas. Dras. Marta Silvia Maria Mantovani e Raquel Glezer, pelo apoio e pela compreensão durante todo 0 período de desenvolvimento do mestrado, além da indicação e empréstimo de referências bibliográficas.

Ao Dr. David Ellis, do Boston's Museum of Science, pela consideração e pronta indicação de referências bibliográficas. 
MASSABKI, Paulo H. B. Centros e museus de ciência e tecnologia. 2011. 274f. Dissertação (Mestrado) - Faculdade de Arquitetura e Urbanismo, Universidade de São Paulo, São Paulo, 2011.

Os centros e museus de ciência e tecnologia foram pouco estudados sob o aspecto arquitetônico. É proposto o conceito de centro de ciência e tecnologia, cuja particularidade é ser focado na experiência e nos fenômenos, e não nos objetos. Existem instituições específicas relacionadas a esse tipo de instituições, em especial o CIMUSET / ICOM, ASTC, ECSITE e ABCMC. Os centros de ciência são protagonistas das mudanças museológicas desde seu surgimento, nos anos 1930. O equivalente da experiência estética dos museus de arte nos museus de ciência é a experiência do processo da ciência. Os objetivos dos centros de ciência são: educacional, divulgação científica, debate e participação, social, motivação, lazer, impacto urbano. Seus públicos alvos principais são famílias e escolas. A internet, a realidade virtual e outras novas tecnologias têm grande impacto nos museus. A interatividade com objetos não é condição suficiente para o aprendizado. São necessários níveis mais profundos de interatividade e interações sociais para o sucesso do aprendizado. Os modelos interativos dos centros de ciências são os equivalentes aos objetos originais nos acervos dos museus tradicionais. A mediação humana é a mais indicada forma de interlocução entre a instituição e o visitante, mas existem outras formas, impessoais, de mediação. Diversos são os recursos expográficos disponíveis para os centros de ciências. Os percursos numa exposição estão relacionados com duas organizações espaciais: linear e episódica. A idéia de museu nasceu há vários séculos, mas o museu moderno surgiu a partir do século XVIII, constituindo uma nova tipologia funcional arquitetônica. Os museus científicos podem ser divididos em três gerações. Suas origens estão associadas às exposições universais. Montaner apresenta uma classificação dos museus contemporâneos em oito posições tipológicas. Há várias visões com relação à essência da arquitetura. Para Zevi é o espaço interior. Para Frampton, é a estrutura. Lynch defende a importância da legibilidade e da imagibilidade da cidade. Os elementos marcantes contribuem para a legibilidade. Eles podem ser edifícios. Para 0 adequado dimensionamento de edifícios de centros de ciências é necessário o estudo de padrões de visitação. A dissertação incluiu o estudo de diversas instituições, especialmente sob o aspecto arquitetônico.

Palavras-chave: Museus de Ciência e Tecnologia. Museus (Arquitetura). Museologia. Science and Technology Centers. 
MASSABKI, Paulo H. B. Science and Technology Centers and Museums. 2011. 274f. Dissertação (Mestrado) - Faculdade de Arquitetura e Urbanismo, Universidade de São Paulo, São Paulo, 2011.

The science and technology centers and museums have been little studied under an architectural point of view. This kind of institution is focused on the experience and phenomena, rather than on objects. There are specific institutions related to such museums, especially the CIMUSET / ICOM, ASTC, ECSITE and ABCMC. Since they appeared in the 1930s, the science centers are important agents of change in the museum field. The equivalent, in science museums, of the aesthetic experience of art museums is the experience of the process of science. The aims of a science center are: educational, scientific dissemination, discussion and participation, social, motivation, leisure, urban impact. Their main public is schools and families. The Internet, virtual reality and other new technologies have great impact on museums. The interactivity with objects is not a sufficient condition for learning. It takes deeper levels of interactivity and social interactions for learning to take place. Interactive models in science centers are the equivalent to the original objects in the traditional museums collections. The human mediation is the most appropriate form of dialogue between the institution and the visitor, but there are other ways. There are several ways of exhibit the collection at science centers. The routes in a museum may be linear or episodic. The idea of the museum was born several centuries ago, but the modern museum appeared in the eighteenth century, and became a new functional architectural typology. Science museums can be divided into three generations. I ts origins are linked to universal expositions. Montaner presents a classification of contemporary museums in eight typologies. The essence of architecture may be the interior space, as for Zevi, or the structure, as for Frampton, or even other aspects. Lynch presents the important concepts of readability and imageability of the city. If they area considerably imageable, buildings may become landmarks. The study of patterns of visitation are required if one wants to design adequate science and technology centers and museums. The dissertation included the study of several institutions, mainly with an architectural view.

Keywords: Science and Technology Museums. Museums (Architecture). Museology. Science and Technology Centers. 


\section{SUMÁRIO}

1. Introdução 10

2. Objetivos e público-alvo 19

2.1. Objetivos 19

2.1.1. Educacional 21

2.1.2. Divulgação científica 27

2.1.3. Debate e participação 31

2.1.4. Social 33

2.1.5. Motivação 37

2.1.6. Lazer 39

2.1.7. Impacto urbano 42

2.2. Público-alvo 44

2.2.1. Famílias 46

2.2.2. Escolas 49

3. Conceitos complementares aos objetivos $\mathbf{5 1}$

3.1. Novas tecnologias e seu impacto nos museus 51

3.2. Interatividade 58

3.3. Mediação 66

4. Museologia e exposições $\quad \mathbf{7 0}$

4.1. Museologia e conceitos fundamentais 70

4.2. Recursos expográficos 76

4.3. Alguns temas museológicos 83

5. Origens e considerações diversas $\quad \mathbf{8 8}$

5.1. Origens e contexto histórico 88

5.1.1. Museu: o nome e a instituição 88

5.1.2. Contexto histórico internacional 89

5.1.3. Contexto brasileiro do Século XX 99

5.1.4. Cronologia 102

5.2. O museu enquanto novo tipo funcional 108

5.3. Considerações arquitetônicas 118

5.4. O programa funcional e observações pragmáticas 126

6. Exemplares estrangeiros e brasileiros 138

6.1. Centros e museus de ciências estrangeiros 138

6.1.1. Cité des Sciences et de l'Industrie 138

6.1.2. California Academy of Sciences 152

6.1.3. Nemo / newMetropolis 159

6.1.4. Rose Center for Earth and Space 167

6.1.5. Outros centros de ciências relevantes 173 
6.2. Centros e museus de ciências brasileiros

6.2.1. Parque de Ciência e Tecnologia (USP) 180

6.2.2. Estação Ciência (USP) 203

6.2.3. Espaço Ciência 217

6.2.4. Museu de Ciências e Tecnologia (PUCRS) 220

6.2.5. Outros centros de ciências relevantes 227

7. Discussões

232

7.1. Comparações

232

7.2. A Esfera: um tema recorrente

236

8. Conclusões

240

9. Referências

244 


\section{INTRODUÇÃO}

Segundo Bachelard, há uma real ruptura entre os conceitos de ciência e senso comum $^{1}$. O ser humano iniciou sua tentativa de compreender o mundo através do senso comum, mas continuou através da ciência ${ }^{2}$, que objetiva compreender a natureza para controlá-la ${ }^{3}$.

Episteme era o termo associado por Platão ao conhecimento científico ${ }^{4}$. Aristóteles $^{5}$ entendia conhecimento científico como a busca das relações de causa e efeito, o que foi questionado vigorosamente no século XVIII por David Hume ${ }^{6}$. Essa crítica foi absorvida pelos filósofos que o seguiram e, "contemporaneamente, admite-se que conhecimento próprio da ciência é aquele que busca investigar as relações de função existentes entre fenômenos" 7 .

A partir de Langlois, Seignobos e Lalande, pode-se definir ciência como o "conjunto de conhecimentos e de investigações com um suficiente grau de generalidade para resultar em convenções concordantes e relações objetivas baseadas em fatos comprováveis" 8.

Segundo Morais, atualmente não é clara a distinção entre ciência e tecnologia, entre o trabalho científico e o trabalho técnico ${ }^{9}$. Entretanto, a distinção teórica tradicional nos coloca scientia relacionada com aprender ou alcançar conhecimento, e téchné como arte no sentido de habilidade ou ofício que segue certas regras. Em termos vulgares poderíamos dizer que "a técnica nos dá o como (ou, o know-how) enquanto a ciência procura nos oferecer o porquê" ${ }^{10}$.

\footnotetext{
${ }^{1}$ MORAIS, 2009, p. 17.

${ }^{2}$ Ibidem, p. 44.

${ }^{3}$ Ibidem, p. 45.

${ }^{4}$ Ibidem, p. 27.

${ }^{5}$ Ibidem, p. 27.

${ }^{6}$ Ibidem, p. 28.

${ }^{7}$ Ibidem, p. 28.

${ }^{8}$ BITTENCOURT; BENCHETRIT; GRANATO, 2006, p. 11.

${ }^{9}$ MORAIS, 2009, p. 17 e 49.

${ }^{10}$ Ibidem, p. 50.
} 
Segundo Tostes, a UNESCO define tecnologia como "o conhecimento e o processo criativo que pode utilizar instrumentos, recursos e sistemas para resolver problemas capazes de estimular a criação e o controle sobre o ambiente natural num esforço para melhorar a condição humana" ${ }^{11}$.

Morais, entretanto, distingue técnica de tecnologia. A técnica estaria associada ao comportamento criativo do ser humano ao longo da história para o atendimento de suas necessidades reais ${ }^{12}$. A técnica se fez tecnologia no momento mais recente "em que foi subvertida pelos interesses econômicos industriais" 13, e no qual “tecnologia gera mais tecnologia em função de lucros e esquecida dos objetivos humanos de vida" ${ }^{14}$, favorecendo a criação de falsas necessidades de consumo ${ }^{15}$. Nessa situação a ciência e a técnica podem deixar de "cumprir sua verdadeira tarefa, qual seja, a de servir à sociedade humana" ${ }^{16}$.

Nada mais contrastante com a perspectiva otimista da virada do século XIX para o XX, quando a ciência se constituía em "um mito que resolveria todos os problemas, além de ser considerada o melhor instrumento para promover uma sociedade civilizada" ${ }^{17}$.

Entretanto, a ciência e a tecnologia têm impacto decisivo na nossa realidade atual e na própria organização de nosso cotidiano familiar ${ }^{18}$. Superada a visão da ciência como fonte de verdades ${ }^{19}$, é necessário buscar formas de disseminar a cultura científica de maneira humanizada e histórica, destacando os esforços em seu desenvolvimento e as relações entre a ciência, a tecnologia e a sociedade ${ }^{20}$. Um dos locais onde isso pode acontecer é o museu:

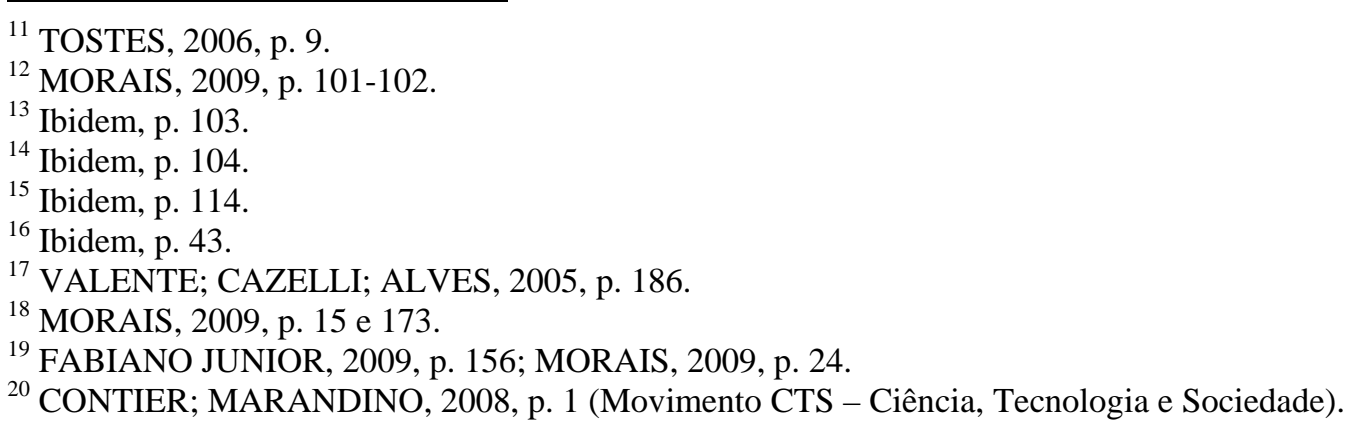


[...] o conhecimento científico, ao ser a chave de interpretação do novo mundo, foi, também, o motor dos museus. Mais além, e sem temer qualquer imprecisão, podemos dizer que a ciência e os museus em sua conotação moderna nasceram juntos. Assim, a ciência não é uma incógnita para os museus, e sim parte integrante de sua constituição ${ }^{21}$.

A divulgação e apreciação do conhecimento humano têm sido feitas não somente nas salas de aula - espaços tradicionais de ensino - mas também nas praças, nos museus de arte, nos museus de história natural e em centros de ciência e tecnologia, entre outros. Esta forma de divulgação pode suprir eventuais carências no ensino convencional, além de ter a evidente vantagem de não atingir somente jovens estudantes, mas, potencialmente, a totalidade da sociedade.

Se o tema museu, ou, especificamente, o museu de arte, foi bastante estudado em dissertações e teses nas faculdades de arquitetura, o mesmo não se pode dizer dos centros ou museus de ciência e tecnologia. A literatura sobre esse tema existe e é até bastante extensa, principalmente na área de educação e divulgação científica, mas não com foco na arquitetura, no espaço e no entorno urbanístico. Por esse motivo se deu a escolha do tema da dissertação.

Serão estudados principalmente os espaços voltados para a divulgação de ciência e tecnologia com abrangência geral, ou seja, não são foco específico da dissertação instituições como museus de história natural, zoológicos, aquários, jardins botânicos, planetários, museus de astronomia, geologia, etc. - ainda que essas instituições sejam abordadas para configurar o surgimento e a consolidação dos espaços supracitados. As instituições estudadas serão aquelas que abordam mais de uma - normalmente várias - áreas da ciência e tecnologia, como física, biologia, matemática, química, geologia, meio-ambiente, etc.

Existem diversas associações ou organizações ao redor do mundo que congregam museus e centros de ciências: a americana ASTC (Association of Science-

\footnotetext{
${ }^{21}$ TOSTES, 2006, p. 8.
} 
Technology Centers), a européia ECSITE (European Network of Science Centres and Museums), a latino-americana REDPOP (Red de Popularización de La Ciencia y La Tecnologia en America Latina y El Caribe). No Brasil temos a ABCMC (Associação Brasileira de Centros e Museus de Ciências), além do IBRAM (Instituto Brasileiro de Museus), que não é específico de museus de ciência, mas trata dos museus em geral.

O órgão internacional mais importante que trata da questão dos museus é o ICOM (International Council of Museums), formalmente relacionado com a UNESCO. Na esfera do ICOM existe o CIMUSET (Comité International des Musées de Sciences Et des Techniques), um comitê internacional específico para os museus de ciência e tecnologia. O CIMUSET agrega tanto os "museus tradicionais de ciência e tecnologia, predominantemente históricos e baseados em coleções" 22 quanto os "centros de ciência contemporâneos, que trabalham principalmente para popularizar e promover a ciência e a tecnologia entre crianças e jovens ao redor do mundo" ${ }^{23}$. É justamente esse segundo tipo de instituição que receberá especial atenção na dissertação.

Segundo Danilov ${ }^{24}$, os Centros de Ciência e Tecnologia - ou Science and Technology Centers - se desenvolveram a partir de outras instituições mais antigas, como os museus de ciência, os da técnica, da indústria, os ligados à área da saúde e os museus de ciência e tecnologia.

A característica fundamental dos centros de ciência e tecnologia - ou simplesmente centros de ciências - é que eles "Iidam com o imaterial - os conceitos e processos da ciência e da tecnologia" ${ }^{25}$. Um reflexo disso é que eles não são focados nos objetos, mas na experiência ${ }^{26}$. Costumam se apoiar na interatividade, seja manual,

\footnotetext{
${ }^{22}$ CIMUSET, 2010.

${ }^{23}$ Ibidem.

${ }^{24}$ DANILOV, 1982, p. 2; CURY, 2000, p. 3.

${ }^{25}$ DANILOV, 1982, p. 4. Tradução nossa, grifo nosso.

${ }^{26}$ Ibidem.
} 
intelectual ou emocional (ou, citando os termos consagrados em inglês, hands-on, minds-on e heart-on) ${ }^{27}$. Eles visam a "compreensão da ciência pelo público, [...] atrair os jovens para o estudo formal de assuntos científicos, o divertimento, o entusiasmo [...]" 28, e focam também as implicações sociais dos princípios científicos e das aplicações tecnológicas ${ }^{29}$. As áreas do conhecimento abordadas costumam ser a física, a química, a biologia, a geologia, a astronomia, a matemática, a engenharia e a medicina ${ }^{30}$.

Os tradicionalistas não considerariam os centros de ciências museus por não terem necessariamente coleções de objetos históricos ${ }^{31}$. Diversos autores apresentam a questão como controversa. Cury afirma que "há defesas e ataques a essa posição" 32. Segundo ela, Bragança Gil e Lourenço ${ }^{33}$ defendem a caracterização dos centros de ciências como museus, mas distinguem os que possuem coleções históricas daqueles compostos por modelos interativos. É semelhante à posição de Guarnieri ${ }^{34}$, que "separa os museus da história da ciência dos museus de ciência" 35, associando os últimos à exposição de fenômenos científicos. Os museus de ciência de Guarnieri são as instituições que a maioria dos autores nomeia centros de ciências.

Apesar de não basear sua expografia em objetos históricos, os centros de ciências também expõem objetos - são os "modelos científicos", normalmente interativos:

O modelo científico surge para atender às necessidades de contextualização e participação: é desenvolvido para a demonstração de princípios ou fenômenos (o que nem sempre é possível com coleções) e para ser manipulado (como

\footnotetext{
${ }^{27}$ DANILOV, 1982, p. 5.

${ }^{28}$ MCMANUS, 2009, p. 56.

${ }^{29}$ DANILOV, 1982, p. 4.

${ }^{30}$ Ibidem, p. 4.

${ }^{31}$ Ibidem, p. viii.

${ }^{32}$ CURY, 2000, p. 2.

${ }^{33}$ BRAGANÇA GIL; LOURENÇO, 1999, apud CURY, 2000, p. 2.

${ }^{34}$ GUARNIERI, 1986, apud CURY, 2000, p. 3.

${ }^{35}$ CURY, 2000, p. 3.
} 
estratégia educacional). Em centros de ciência os modelos são os correspondentes materiais das coleções museológicas ${ }^{36}$.

Danilov afirma que nos museus históricos ou artísticos, de forma geral, os objetos apresentados são belos, únicos e de valor inestimável. Ocorre o contrário nos centros de ciências, onde a beleza ou o valor estético dos modelos científicos são secundários, eles não têm valor intrínseco significativo e não há obstáculos para a sua reprodução. As sucessivas cópias construídas pela mesma ou por outras instituições podem, inclusive, apresentar melhorias que as tornem mais eficazes no cumprimento das suas funções de demonstração. As questões de autenticidade ${ }^{37}$, aura $^{38}$ e valor de culto ${ }^{39}$ não se aplicam.

O sistema ICOM/CIMUSET, ao englobar os centros de ciência contemporâneos, conforme citado anteriormente, claramente considera os centros de ciências como museus $^{40}$.

Segundo Valente, Cazelli e Alves ${ }^{41}$, iniciou-se nos anos 1960 um movimento internacional de mudança na prática e no papel social dos museus, no qual os de ciência e tecnologia tiveram importante atuação, pois seus objetivos não se restringiam à preservação de objetos históricos, mas se concentravam na divulgação científica e no estímulo às carreiras da área científica.

A assinalar ainda mais tal mudança surge, principalmente nos Estados Unidos, um tipo de museu de ciência de contorno multidisciplinar integrando ciência, tecnologia e arte e recorrendo amplamente às técnicas interativas de caráter experimental. São os denominados science centers, espaços que provocam, atraem, seduzem e motivam o visitante a entrar em contato com alguns

\footnotetext{
${ }^{36}$ CURY, 2000, p. 2.

${ }^{37}$ BENJAMIN, 1936, p. 167.

${ }^{38}$ Ibidem, p. 170.

${ }^{39}$ Ibidem, p. 173.

${ }^{40}$ CIMUSET, 2010.

${ }^{41}$ VALENTE; CAZELLI; ALVES, 2005, p. 189.
} 
fundamentos da ciência e da tecnologia por meio de experimentos do tipo 'faça você mesmo'42.

Danilov entende que as novas características abraçadas pelos centros de ciências eram, em parte, respostas à “mudança de atitudes, necessidades e expectativas do público visitante" ${ }^{43}$.

Antes do surgimento dos centros de ciência e tecnologia, a expressão "museu de ciências" estava relacionada principalmente à história natural e às coleções históricas. Com o crescimento do número e popularidade desses centros eles passaram mesmo a absorver o nome "museus de ciências", sendo chamados quase indistintamente de centros ou museus de ciência e tecnologia ${ }^{44}$.

Há que se destacar que a expressão "museus de ciências de tecnologia" é mais abrangente, pois inclui "os convencionais museus de ciências, os museus de indústria, os ecomuseus, mas também aqueles 'exploratoria' e centros interativos [...]" ${ }^{45}$. Ou seja, os centros de ciências nada mais são do que um tipo de museu de ciências.

Eles surgiram nos Estados Unidos a partir de 1930 aproximadamente ${ }^{46}$. Ao longo do seu processo de consolidação, predominaram por parte dos autores que trataram do assunto as ênfases nas suas características específicas, que os diferenciariam dos museus tradicionais: objetivam a promoção do entendimento e da apreciação pública das ciências através do esclarecimento e do divertimento e enfatizam as perspectivas contemporâneas ao invés das históricas e as técnicas participativas ao invés das passivas focadas nos objetos ${ }^{47}$. Cury considera que “museus e centros de ciência possuem diferenças e dinâmicas distintas, traçadas,

\footnotetext{
${ }^{42}$ VALENTE; CAZELLI; ALVES, 2005, p. 189.

43 DANILOV, 1982, p. 3.

${ }^{44}$ Ibidem, 1982, p. 5-6.

${ }^{45}$ LOPES, M. M., 2009, p. 199.

${ }^{46}$ DANILOV, 1982, p. viii.

${ }^{47}$ Ibidem, p. 2; HENSLEY, 1991; GASPAR, 1993.
} 
entre outras coisas, pelo uso ou não de coleções e/ou modelos" ${ }^{48}$. Mas apresentam várias afinidades, como o compromisso com a divulgação do conhecimento científico e tecnológico, a comunicação e o ensino da ciência, e atuação no campo da educação informal ${ }^{49}$.

Em textos mais recentes, outros autores minimizam as diferenças e reforçam as similaridades entre os centros de ciências e os museus em geral, incluindo os de ciências. Rodari e Merzagora consideram as diferenças entre os centros de ciências e museus "atualmente cada vez menos claras" ${ }^{50}$, enquanto Chagas não vê sentido na diferenciação "entre museus de ciências naturais, museus de ciências sociais e museus de arte" ${ }^{51}$, pois "todos os museus estão na ordem da cultura e são fenômenos sociais complexos [...]" ${ }^{52}$, e as funções artística, estética, científica e tecnológica estão presentes em maior ou menor grau tanto nos museus de ciência quanto nos de arte.

No Capítulo 2 será apresentada a definição de museus do ICOM (International Council of Museums), os conceitos de fruição, experiência estética, experiência de fluência e experiência do processo da ciência. Serão relacionados e discutidos os objetivos dos centros de ciência e tecnologia, notadamente: educacional, divulgação científica, debate e participação, social, motivação, lazer, e impacto urbano. Questões relacionadas à caracterização dos públicos alvos principais famílias e escolas - serão abordadas.

No capítulo seguinte se discutirá como as novas tecnologias estão impactando nos museus, a questão da virtualidade, da interatividade, dos tipos de interação e da mediação entre a instituição e o visitante.

\footnotetext{
${ }^{48}$ CURY, 2000, p. 4.

${ }^{49}$ Ibidem, p. 4.

${ }^{50}$ RODARI; MERZAGORA, 2007, p. 1. Tradução nossa.

${ }^{51}$ CHAGAS, 2007, p. 29.

${ }^{52}$ Ibidem, p. 29.
} 
Para um bom entendimento das pesquisas realizadas sobre o assunto, no Capítulo 4 serão discutidos conceitos relacionados à museologia e às exposições. Serão discutidos temas museológicos contemporâneos e com grande influência no tema da dissertação.

No Capítulo 5 serão tratados conceitos fundamentais para a discussão arquitetônica, como as origens dos museus, a caracterização dos museus científicos em gerações, o surgimento dos museus no contexto brasileiro, a discussão sobre tipologia, conceituações arquitetônicas e urbanísticas, as posições tipológicas de Montaner e considerações práticas sobre o programa dos centros e museus de ciências.

O Capítulo 6 tratará da apresentação de diversos centros e museus de ciências, tanto estrangeiros quanto brasileiros, sendo dado destaque para a Cité des Sciences et de I'Industrie, a California Academy of Sciences, o Nemo / newMetropolis, o Rose Center for Earth and Space, o Parque de Ciência e Tecnologia (USP), a Estação Ciência (USP), o Espaço Ciência, e o Museu de Ciências e Tecnologia (PUCRS).

No Capítulo 7 serão feitas comparações entre as diversas obras estudadas, e será discutido um tema recorrente: a esfera arquitetônica.

O capítulo final é o de Conclusões, no qual serão retomadas as questões que se tiverem mostrado mais significativas no estudo do tema, tanto as mais consensuais quanto aquelas mais polêmicas e que deverão ter grande relevância nos próximos anos.

Ao final da dissertação devemos conseguir ter uma visão bastante abrangente dos centros e museus de ciência e tecnologia, sob os aspectos institucionais, museológicos, arquitetônicos e urbanísticos. 


\section{OBJETIVOS E PÚBLICO ALVO}

\subsection{Objetivos}

Os diversos estatutos que o ICOM (International Council of Museums) teve ao longo do tempo continham definições da instituição Museu e de suas funções ${ }^{1}$. Desde 1951 a instrução e a fruição ${ }^{2}$ estão incluídas em seus objetivos. Em 1961 surge na definição a palavra educação, talvez mais significativa do que simplesmente instrução. Em 1974 os centros de ciências passam a estar explicitamente citados como museus, e o termo comunicação aparece pela primeira vez. Em 1989 a alteração foi a troca da expressão "homem" por "pessoas". A definição se manteve inalterada até 2007, quando o termo evidência foi substituído por patrimônio (ou herança) e a palavra imaterial foi acrescentada em adição ao material. O estatuto mais recente, de 2007, assim define museu:

A museum is a non-profit, permanent institution in the service of society and its development, open to the public, which acquires, conserves, researches, communicates and exhibits the tangible and intangible heritage of humanity and its environment for the purposes of education, study and enjoyment. ${ }^{3}$

Vários objetivos estão aqui relacionados, implícita ou explicitamente. O museu está "a serviço da sociedade e de seu desenvolvimento", e tem, portanto, função e responsabilidade social. Ele "adquire, conserva, pesquisa, comunica e expõe". Ele trata do patrimônio (ou "herança") material e imaterial.

A definição contém um outro aspecto importante. Declara explicitamente os objetivos de "educação, estudo e fruição".

Quase todos esses objetivos estão presentes nos centros de ciência e tecnologia. Particularmente, são voltados para a educação e a comunicação, e expõem

\footnotetext{
${ }^{1}$ ICOM, 2010.

${ }^{2}$ No original, “delectation”.

${ }^{3}$ ICOM, 2007.

${ }^{4}$ No original, "enjoyment".
} 
patrimônio imaterial: "science centers often are dealing with the intangible - the concepts and processes of science and technology" 5 . Mesmo dentro de uma definição geral de museu, essas instituições estariam plenamente inseridas - são museus.

O termo "fruição" significa "desfrute", “gozo", "deleite”, “ato de aproveitar satisfatória e prazerosamente alguma coisa" ${ }^{6}$, e está diretamente relacionado com a "experiência estética". Esta consiste numa forma de relação com o mundo em que vivemos que dá destaque "à consciência perceptiva ou intuitiva direta" desse entorno, e que "vale a pena por si mesmo e pela consciência intensificada do mundo que proporciona" ${ }^{7}$. Embora

possamos assumir uma atitude estética em relação a qualquer coisa, nem todas as coisas são igualmente capazes de sustentar a contemplação estética num ponto elevado. [...] os objetos de arte estão mais adaptados à expansão e à sustentação da sensibilidade madura.

Outro aspecto da experiência estética, pela definição citada supracitada, é que ela é uma atividade auto-recompensadora. "Para Aristóteles, atividade autorecompensadora era aquela que não servia a nenhum propósito ulterior ou utilitário, mas podia ser adequadamente exercida por um homem livre na ocupação de seu lazer" 8.

Chambers considera as experiências em museus como variedades da chamada “experiência de fluência" ${ }^{9}$, que é um conceito do psicólogo comportamental Mihalyi Csikszentmihalyi, assim definido por ela:

um termo frequentemente usado [...] para descrever 'o profundo envolvimento e a evolução espontânea' que se sente quando uma atividade

\footnotetext{
${ }^{5}$ DANILOV, 1982, p. 4.

${ }^{6}$ HOUAISS, 2001a. Verbete fruição.

${ }^{7}$ OSBORNE, 1968, p. 24.

${ }^{8}$ Ibidem, p. 270. Grifo nosso.

${ }^{9}$ CHAMBERS, 1990, p. 10. Tradução nossa. No original, “experience of 'flow'”.
} 
vai bem - é o que dá motivação para gastar tempo fazendo algo que não tem recompensa além do próprio ato em $\mathrm{si}^{10}$.

Portanto, a experiência estética em um museu de arte é uma experiência de fluência, que guarda relação e semelhança com o que Chambers define como "experiência do processo da ciência" ${ }^{11}$, possível de acontecer com um visitante num museu de ciências. Entretanto, essa experiência de fluência só poderá ocorrer se for dada maior ênfase à experiência em si do que no ensino de fatos ou princípios objetivos $^{12}$.

Os diversos autores que tem tratado dos centros de ciência e tecnologia e museus discutem alguns dos objetivos descritos acima, os desenvolvem, acrescentam novos pontos de vista e interpretações, assim como novas ênfases. Diversos foram os temas abordados, que podem ser entendidos às vezes como objetivos específicos, e às vezes como diferentes aspectos de objetivos mais gerais. Não são estanques, e muitas vezes se completam e até se confundem nos textos dos diversos autores. São eles: Educacional; Divulgação Científica; Debate e Participação; Social; Motivação; Lazer; Impacto Urbano.

\subsubsection{Educacional}

Vasta literatura indica a educação como o mais importante objetivo a ser alcançado pelos centros de ciências. Conceitos relacionando o aprendizado à interatividade serão discutidos no Capítulo 3.

\footnotetext{
${ }^{10}$ CHAMBERS, 1990, p. 10. Tradução nossa.

${ }^{11}$ Ibidem, p. 10. Tradução nossa.

${ }^{12}$ Ibidem, p. 11.
} 
Certamente o ensino desenvolvido nessas instituições, na maior parte das situações, não é formal. Entretanto, alguns autores o definem como informal ${ }^{13}$, enquanto outros o descrevem como não-formal ${ }^{14}$.

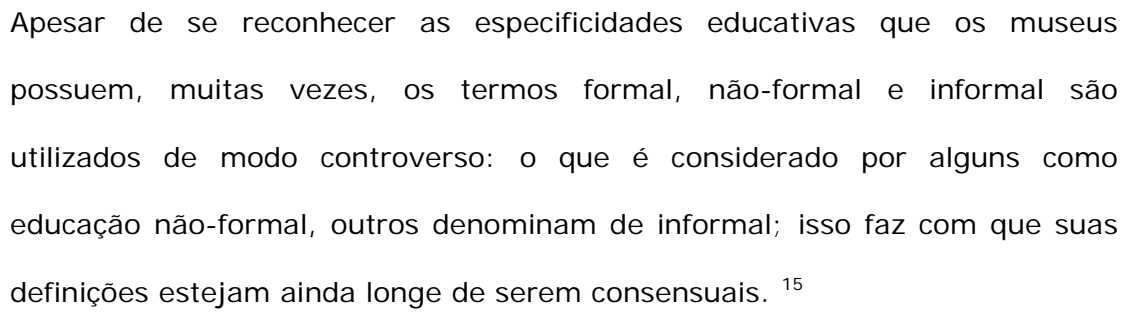

A literatura anglofônica, por exemplo, engloba ambas em torno do termo “informal", enquanto a literatura lusofônica as diferencia ${ }^{16}$.

Considerando a subdivisão em três categorias, entretanto, há alguma convergência nas definições ${ }^{17}$ :

a) Educação formal: ligada à escola, à estrutura oficial de ensino, hierarquicamente estruturada e cronologicamente graduada, com currículos relativamente rígidos;

b) Educação não-formal: com currículos e metodologias flexíveis, fora da estrutura formal oficial, mas que tem objetivos de aprendizagem. Esse conceito englobaria cursos de capacitação profissional, de idiomas, de alfabetização de adultos etc.;

c) Educação informal: pode se dar ao longo de toda a vida e decorre das relações cotidianas familiares, de trabalho, de lazer, e das influências provenientes das diversas mídias de massa.

\footnotetext{
${ }^{13}$ GASPAR, 1993; WELLINGTON, 1990; VAN PRAET; DAVALLON; JACOBI, 2005; GARCÍA BLANCO, 1999, apud MARANDINO et al, 2004; CURY, 2000.

${ }^{14}$ MARANDINO, 2008; CHAGAS, 1993, apud MARANDINO et al, 2004.

${ }^{15}$ MARANDINO, 2008, p. 12.

${ }^{16}$ Ibidem, p. 12.

${ }^{17}$ GASPAR, 1993; COMBS; PROSSER; AHMED, 1973, apud MARANDINO, 2008; GARCÍA

BLANCO, 1999, apud MARANDINO et al, 2004.
} 
Se considerarmos as três categorias de educação "como um continuum e não como categorias estanques" ${ }^{18}$ podemos, dependendo da situação, encaixar o museu em cada uma delas. Ele pode ser visto como não-formal ${ }^{19}$, ou até como formal ${ }^{20}$, quando o visitante utiliza-se repetidamente de atividades sistemáticas do museu ${ }^{21}$, ou "quando alunos o visitam com uma atividade totalmente estruturada por sua escola" 22. E pode ser considerado educação informal "ao pensarmos em um visitante que procura um museu para se divertir em um final de semana com seus amigos e familiares" ${ }^{23}$, em visitas "não muito estruturadas, em grande medida espontâneas e muito personalizadas" 24 .

Alguns autores enfatizam a alfabetização científica, outros discutem a questão do apoio e da complementação ao ensino escolar, no qual se inclui a formação de professores.

A alfabetização científica envolve o entendimento das normas da ciência, o conhecimento de suas teorias, conceitos e princípios mais importantes, a consciência do impacto da ciência e da tecnologia na sociedade, a habilidade de aplicar o conhecimento científico no cotidiano, e a compreensão crítica de um artigo de jornal ou revista sobre um assunto científico e tecnológico ${ }^{25}$. Ela é importante por que contribui para a criação de uma força de trabalho tecnologicamente qualificada e para a promoção do engajamento do público na ciência ${ }^{26}$.

Gaspar defende que a alfabetização científica não pode se dar apenas na esfera da educação formal (escola), por que esta

\footnotetext{
${ }^{18}$ ROGERS, 2004, apud MARANDINO, 2008, p. 14.

${ }^{19}$ PADILLA, 2001, p. 119.

${ }^{20}$ MARANDINO, 2008, p. 15.

${ }^{21}$ PADILLA, 2001, p. 119.

${ }^{22}$ MARANDINO, 2008, p. 15.

${ }^{23}$ Ibidem, p. 15.

${ }^{24}$ PADILLA, 2001, p. 119.

${ }^{25}$ HENSLEY, 1991.

${ }^{26}$ Ibidem.
} 
tem como matéria prima o conhecimento organizado, sistematizado, o que forçosamente retarda a sua atualização, já que as conquistas da ciência e da tecnologia obviamente não acompanham a seqüência curricular ${ }^{27}$.

Além disso, "muitos já não a freqüentam" ${ }^{28}$, o que limita a sua atuação a um público alvo específico.

Os centros de ciências, por outro lado, são abertos a qualquer público, de diferentes faixas etárias e níveis sócio-culturais. São os locais ideais para a promoção da alfabetização científica, pois

\footnotetext{
a influência das atividades dos museus e centros de ciências não se limita aos seus visitantes; ela tem ação indireta também sobre os próprios meios de comunicação, que neles podem encontrar o material necessário para desenvolver sua função e, reciprocamente, divulgar essas atividades ${ }^{29}$.
}

Eles podem proporcionar "uma educação continuada em ciências após o término da educação formal" ${ }^{30}$, considerando, inclusive, que "o conhecimento dos adultos sobre os temas científicos mais atuais e relevantes não advém das experiências escolares, mas da interação com as diversas mídias e os museus de ciência" ${ }^{31}$. E também contribuem para a reformulação das concepções anteriores dos visitantes ${ }^{32}$.

Os museus e centros de ciências são às vezes vistos como apoio ou complemento da educação formal, atuando como "laboratórios" das escolas e auxiliando na formação e reciclagem de professores. Nessa situação, eles se aproximam da categoria de educação não-formal ou até formal (ver página anterior). Maurício ${ }^{33}$ afirmava em 1992 que, à época, no Brasil, os centros de ciências estavam mais

\footnotetext{
${ }^{27}$ GASPAR, 1993, Capítulo IV - Item 2.2 - O papel da escola.

${ }^{28}$ Ibidem.

${ }^{29}$ Ibidem, Item 2.4 - O papel dos museus e centros de ciências.

${ }^{30}$ VALENTE; CAZELLI; ALVES, 2005, p. 190.

${ }^{31}$ Ibidem, p. 200.

${ }^{32}$ MARANDINO, 2005, p. 179.

${ }^{33}$ MAURÍCIO, 1992, p. 50.
} 
focados na reciclagem de professores, "normalmente mal formados", e davam pouca atenção aos estudantes.

Duas questões são constantemente discutidas pelos autores que abordam o centro de ciências como apoio à escola: é desejável que eles assim se posicionem? E eles são efetivos atuando dessa forma?

Studart afirma que
Apesar de muitos profissionais atualmente discordarem da idéia do uso do museu como complemento da educação escolar, os estudantes são um público alvo importante dos museus. Muitos professores (e também pais) procuram museus para ilustrar conteúdos da escola para a criança, ou para melhor entender esses conteúdos ${ }^{34}$.

Ela ressalta, entretanto, que outros defendem a ação do museu com objetivo bastante diferente, de "informar e sensibilizar o público sobre questões relacionadas ao campo temático do museu e a sua influência na sociedade" ${ }^{35}$.

Wagensberg $^{36}$, por exemplo, defende que “A prioridade do museu é o estímulo, não a educação, embora ela não esteja proibida. Uma visita dura três horas, não há tempo de educar mas, sim, para mudar a atitude diante da educação". Em outra entrevista, justifica: "Quando um museu de ciências tiver que oferecer ensino básico, significa que a educação como um todo está com deficiências graves" 37. Essa visão reforça a visão do museu como instrumento de educação informal.

McManus ${ }^{38}$ aponta para “[...] um perigo de redução na qualidade e no caráter dos recursos culturais comunitários, caso os Museus e Centros de Ciências passem a ser vistos [...] como prolongamentos ou acessórios do sistema escolar". Essa visão é compartilhada por Chagas, que destaca a importância do museu "no

\footnotetext{
${ }^{34}$ STUDART, 2009, p. 115.

${ }^{35}$ Ibid., p. 115.

${ }^{36}$ WAGENSBERG, 2003, p. 16.

${ }^{37}$ Idem, 2005b.

${ }^{38}$ MCMANUS, 2009, p. 56.
} 
desenvolvimento de práticas educativas independentes da rede formal de ensino" 39.

Esse perigo não deve ser desprezado. Guisasola, Morentin e Zuza ${ }^{40}$ descrevem um processo no qual a visita ao museu de ciências é totalmente programada, com um material didático preparado pelos professores. Ele consiste em algo como um guia escrito, composto por exemplos da vida real, apresentação dos conceitos a serem estudados, descrição das exibições a serem visitadas, algumas perguntas sobre o assunto. Há alguns textos relativamente extensos para serem lidos antes e depois da visita, e um texto mais curto para ser lido durante a visita. Os autores defendem esse processo dizendo que sem um planejamento rigoroso - como o que eles propõem - a visita, do ponto de vista didático, é uma "perda de tempo e dinheiro" 41. Por outro lado, parece-nos que, apesar de provavelmente ser didático de um ponto de vista tradicional, o método proposto pode tirar muito da graça e do "deslumbramento" da visita, e tornar as exibições meros equipamentos de laboratório da escola, reduzindo, de fato, o papel do museu.

Mas esse modelo de visita altamente disciplinado reflete uma preocupação com a eficácia dos museus em ensinar conteúdos, o que nos remete à nossa segunda questão. Em um estudo sobre público de famílias do Museu de Astronomia e Ciências Afins (MAST), no Rio de Janeiro, desenvolvido entre 2001 e 2002, Studart ${ }^{42}$ verificou que as crianças fizeram relações entre conteúdos da escola e do museu apenas quando o assunto estava sendo estudado na escola naquele momento. A partir disso, ela concluiu que

[...] os museus certamente podem estimular conexões entre os conteúdos vistos na escola e aqueles vistos no museu, favorecendo um maior

\footnotetext{
${ }^{39}$ CHAGAS, 2002, p. 56.

${ }^{40}$ GUISASOLA; MORENTIN; ZUZA, 2005.

${ }^{41}$ Ibidem, p. 549. Tradução nossa.

${ }^{42}$ STUDART, 2009.
} 
entendimento de temas comuns [...]. O grande desafio dos museus é, todavia, apresentar esses conteúdos de uma maneira não escolarizada ${ }^{43}$.

Essa parece ser a chave do problema. Se o museu for entendido com suas particularidades, e forem respeitadas suas características próprias, parece possível que ele funcione tanto como um grande estimulador quanto como uma ferramenta de apoio à escola, considerando as deficiências de ensino do Brasil. Frank Oppenheimer, fundador do Exploratorium de São Francisco, afirma que "O Exploratorium [...] é um acréscimo [à escola] e é concebido para alcançar objetivos educacionais e culturais que são difíceis de alcançar na escola" ${ }^{44}$.

\subsubsection{Divulgação Científica}

Qual seria a diferença entre a educação que ocorre nos museus e centros de ciência e a divulgação científica?

Barros enfatiza que "divulgar não é ensinar" ${ }^{45}$ :

A divulgação tem outro objetivo. Pode servir tanto como instrumento motivador quanto como instrumento pedagógico, mas, em nenhum dos casos, espera-se que vá substituir o aprendizado sistemático ${ }^{46}$.

Entretanto, quando utiliza a expressão "aprendizado sistemático" está claramente se referindo à educação formal. Como visto no item anterior, para a maioria dos autores, e na maior parte das situações, a educação que ocorre nos museus e centros de ciências não é formal.

Mas quando se fala em ensino informal e não-formal os limites que os diferenciam da divulgação não são tão claros. "Entre os autores que discutem a divulgação

\footnotetext{
${ }^{43}$ STUDART, 2009, p. 113.

${ }^{44}$ OPPENHEIMER, 1975, apud GASPAR, 1993, Capítulo V - Item 3 - Implicações da teoria de Vygotsky ao processo ensino-aprendizagem em museus e centros de ciências.

${ }^{45}$ MARANDINO et al, 2004, p. 5.

${ }^{46}$ BARROS, 1992, p. 65, apud MARANDINO et al, 2004, p. 5.
} 
científica não existe um consenso relativo à definição dos termos ensinar e divulgar" 47. José Reis, por exemplo, defende que as funções da divulgação científica são ensinar e fomentar o ensino ${ }^{48}$.

Há no Brasil atualmente "uma hegemonia no uso da expressão divulgação científica" 49 sobre outros termos considerados seus sinônimos (vulgarização, popularização e comunicação pública) ${ }^{50}$. Alguns autores utilizam as expressões divulgação científica e difusão científica indistintamente, enquanto outros as diferenciam ${ }^{51}$. Bueno, em particular, caracteriza a divulgação científica como "a transposição de uma linguagem especializada para uma linguagem não especializada, com o objetivo de tornar o conteúdo acessível a uma vasta audiência" ${ }^{52}$, o que nos parece uma definição bastante boa.

Outra questão a ser considerada é a do chamado "modelo de déficit de divulgação científica" ${ }^{53}$, no qual o visitante é visto como leigo ${ }^{54}$ cuja ignorância deve ser superada através da ação direta e unidirecional do museu, com ênfase nos conteúdos $^{55}$. Essa postura estaria por vezes sendo substituída por uma comunicação bidirecional, na qual "as experiências e informações prévias do público começaram a ser consideradas como elementos chave para favorecer a compreensão de assuntos específicos" ${ }^{56}$. Entretanto, Cury destaca que "Colocar a questão sob o viés do público não significa retirar a responsabilidade do emissor [...]" 57. Mas quem define a informação e os conteúdos em nossos museus de

\footnotetext{
${ }^{47}$ MARANDINO et al, 2004, p. 5.

${ }^{48}$ Ibidem, p. 5.

${ }^{49}$ MASSARANI, 1998, apud MARANDINO et al, 2004, p. 4.

${ }^{50}$ Ibidem, p. 4. VAN PRAET; DAVALLON; JACOBI, 2005, p. 360.

${ }^{51}$ MASSARANI, 1998; BUENO, 1985, apud MARANDINO et al, 2004, p. 4.

${ }^{52}$ BUENO, 1985, apud MARANDINO et al, 2004, p. 4.

${ }^{53}$ LEWENSTEIN, 2003, apud MARANDINO, 2008, p. 16.

${ }^{54}$ MARANDINO, 2008, p. 16.

${ }^{55}$ FAYARD, 1999, apud MARANDINO et al, 2004, p. 2.

${ }^{56}$ MARANDINO, 2008, p. 16.

${ }^{57}$ CURY, 2006, 43.
} 
ciência e tecnologia? Blache afirma que "o conhecimento vem das pessoas que o possui: os cientistas" ${ }^{58}$.

Segundo Wagensberg, "a ciência está exercendo uma influência cada vez maior na vida diária das pessoas comuns e que o conhecimento científico é uma prioridade para o progresso e a independência das pessoas" ${ }^{59}$. Assim, a divulgação científica é importante para que o povo consiga influenciar nas decisões dos políticos: “Em um sistema democrático, eles são pressionados pela opinião pública, pelo voto. Por isso, os cientistas devem transferir seus conhecimentos ao eleitor, e o eleitor aos políticos" ${ }^{60}$. "Um museu [...] é, em minha opinião, uma exigência democrática e um excelente centro no qual podemos desenvolver a identificação coletiva" ${ }^{61}$.

Studart caminha na mesma direção quando afirma que há

[...] necessidade de uma rede de educação e divulgação científica [...] para a construção de uma sociedade mais atuante, onde os museus possam ser, cada vez mais, espaços de descoberta e instrumentos de diálogo, comunicação, reflexão e formação de atitudes [... ${ }^{62}$.

Dentro dessa rede estão incluídos o jornalismo científico, a televisão e a internet. 0 jornalismo científico teve papel precursor na divulgação no Brasil, com o Dr. José Reis escrevendo durante décadas no jornal Folha de S. Paulo ${ }^{63}$. A televisão tem dado atenção à ciência, mas "a maior parte dos programas atuais deixa a ciência moderna de lado e tem como objeto grandes espetáculos" ${ }^{64}$, ou seja, tem como foco não a importância dos temas para a alfabetização científica do telespectador, mas o poder de atração do assunto e sua perenidade, objetivando que o programa produzido não fique desatualizado e possa ser reapresentado diversas vezes, cobrindo os custos de produção e maximizando os lucros.

\footnotetext{
${ }^{58}$ BLACHE, 2007, p. 118.

${ }^{59}$ WAGENSBERG, 2005a, p.19.

${ }^{60}$ Idem, 2003, p. 16.

${ }^{61}$ Idem, 2005a, p. 19.

${ }^{62}$ STUDART, 2009, p. 115.

${ }^{63}$ HAMBURGER, 2001, p. 36.

${ }^{64}$ VALENTE, L., 2008, p. 1. Numeração nossa.
} 
Entretanto, a TV tem um grande potencial de penetração na população em geral ${ }^{65}$, e é particularmente importante para atingir as classes sociais mais baixas, o que indica a relevância de buscar soluções para os problemas apontados no sentido de melhorar sua influência na alfabetização científica da população.

O centro de ciências é um dos agentes importantes da divulgação científica, estando essa sua função já bastante consolidada.

McManus argumenta que "uma premência quanto à compreensão da ciência pelo público" ${ }^{66}$ é uma das características que definem os centros de ciências.

Valente, Cazelli e Alves apontam os museus de ciências contribuindo para o “entendimento público da ciência" ${ }^{67}$, a "difusão de princípios científicos e tecnológicos" ${ }^{68}$, tendo "como principal missão comunicar e socializar o conhecimento" 69 visando "promover a formação de cidadãos capazes de interferir criticamente na realidade para transformá-la" 70 .

Uma boa divulgação científica, segundo Wagensberg, deve ser feita por "aqueles que estão aptos e acostumados a falar com todos" ${ }^{71}$. E exemplifica: "Na Espanha, os cientistas quando precisam divulgar seus resultados vão até o Museu e pedem sua intermediação junto à comunidade e à imprensa" ${ }^{72}$. Esse divulgador que atua como mediador entre o cientista e o público é chamado de "terceiro homem" ${ }^{73}$ por alguns autores: pode ser jornalista, especialista de mídias, pessoal dos museus ou docente de ciências.

\footnotetext{
${ }^{65}$ HAMBURGER, 2001, p. 31; SIQUEIRA, 2008, p. 1. Numeração nossa.

${ }^{66}$ MCMANUS, 2009, p. 56.

${ }^{67}$ VALENTE; CAZELLI; ALVES, 2005, p. 184.

${ }^{68}$ Ibidem.

${ }^{69}$ Ibidem.

${ }^{70}$ MACEDO, 2002, p.137, apud VALENTE; CAZELLI; ALVES, 2005, p. 194.

${ }^{71}$ WAGENSBERG, 2005b.

${ }^{72}$ Ibidem.

${ }^{73}$ VAN PRAET; DAVALLON; JACOBI, 2005, p. 362.
} 


\subsubsection{Debate e participação}

Associado à divulgação científica, e talvez como um estágio evolutivo posterior, está a questão do debate e da participação mais ativa do público em questões científicas e tecnológicas contemporâneas.

Em texto de 1991 Hensley $^{74}$ defende que a missão do centro de ciência é exatamente abordar essas questões sob os pontos de vistas social, cultural, ético, factual, conceitual e interpretativo, de forma a que o público possa "formular opiniões razoáveis, assumir riscos, e ajudar a tomar decisões difíceis através da ação política" ${ }^{75}$. Segundo ele, à época, os centros não eram bem-sucedidos nessa missão, e privilegiavam apenas fatos e conceitos.

Textos mais recentes de outros autores parecem apontar para uma mudança nessa situação: os museus estariam cada vez mais cumprindo efetivamente essa função.

Rodari e Merzagora ${ }^{76}$ defendem que os centros de ciência estão assumindo novos papéis. Se antes eram locais de produção, conservação, melhoria e representação do conhecimento científico, passaram também a estabelecer a mediação entre a comunidade científica e a sociedade em geral, e, mais recentemente, a promover a negociação do conhecimento científico - o que se pode entender como uma postura mais aberta entre esses dois grupos. Eles afirmam que no mundo atual os cidadãos são chamados a expressar suas opiniões, e mesmo a contribuir com sua visão de "usuário final" para a tomada de decisões ${ }^{77}$.

Se no mundo contemporâneo não é mais possível falar em "fatos" e "verdades" gerais, Cameron ${ }^{78}$ aponta para uma conseqüente redefinição dos papéis do museu, que passa a apresentar assuntos polêmicos com os diversos pontos de vista, de

\footnotetext{
${ }^{74}$ HENSLEY, 1991.

${ }^{75}$ Ibidem, p. 79.

${ }^{76}$ RODARI; MERZAGORA, 2007.

${ }^{77}$ Ver também SCHAUBLE; BARTLETT, 1997.

${ }^{78}$ CAMERON, 2005.
} 
forma a que o visitante possa, bem informado, se posicionar. Essas questões são normalmente controversas, e o museu deve agir como mediador, permitindo que o visitante chegue a suas próprias conclusões sobre os assuntos e encorajando a “auto-expressão" 79. Wagensberg parece concordar, quando defende a "exibição de alternativas plausíveis diferentes" ${ }^{80}$. Embora a TV venha dando espaço para temas científicos controversos em sua programação - porque naturalmente atraem bastante audiência - ela normalmente não apresenta a "complexidade do fazer científico" nem as "diferentes vozes da ciência" ${ }^{81}$.

Segundo Cameron ${ }^{82}$, vários são os papéis que o museu deve desempenhar, quando associado a esses assuntos polêmicos. Ele pode ser fonte de informações, pois tem altíssima credibilidade; pode propiciar experiências de interação social - inclusive exibições - nas quais os temas são debatidos e o visitante consegue absorvê- $\operatorname{los}^{83}$; pode questionar pontos de vista ao apresentar outras visões; pode propiciar às pessoas chegar às suas próprias conclusões; pode transformar o visitante ao gerar empatia por outros pontos de vista. O museu de ciências é "um dos poucos lugares onde estes debates podem acontecer" ${ }^{84}$. Essa visão da relação entre o museu e o público no qual este é mais atuante e participativo é chamada por Cameron de “autoridade compartilhada" 85.

Bell $^{86}$ defende ponto de vista bastante semelhante. Os museus de ciências devem ajudar os adultos a pensar sobre questões contemporâneas complexas e decisões a serem tomadas pelos indivíduos, comunidades e sociedades, pois são talvez os únicos agentes que possam realizar essa função, promovendo um encontro natural

\footnotetext{
${ }^{79}$ Ibidem, p. 215. Tradução nossa.

${ }^{80}$ WAGENSBERG, 2005a, p. 5.

${ }^{81}$ VALENTE, L., 2008, p. 1. Numeração nossa.

${ }^{82}$ CAMERON, Op. Cit.

83 Ibidem, p. 225. Tradução nossa. No original, come to terms with.

${ }^{84}$ Ibidem, p. 228. Tradução nossa. Ver também CURY, 2005.

${ }^{85}$ Ibidem, p. 229-230. Tradução nossa. No original, shared authority.

${ }^{86}$ BELL, 2008.
} 
entre diversos grupos sociais: cientistas, empresários, políticos, imprensa, professores, estudantes e público em geral.

Sob uma óptica mais filosófica, Chagas e Storino definem os museus como "elos políticos [...] entre o indivíduo e a sociedade" ${ }^{87}$, com aptidão para "exercitar pensamentos, tocar afetos, estimular ações, inspirações e intuições" ${ }^{88}$.

Sandell ${ }^{89}$ aponta para uma participação ativa do público inclusive na definição das ações do próprio museu, desenvolvendo mecanismos através dos quais ele possa participar da tomada de decisões da instituição:

To be more effective as agents of social inclusion, museums must seek to renegotiate the basis of their relationship with communities. Rather than developing aims and objectives internally, based on the organization's agenda and priorities, museums must learn to develop mechanisms through which communities can be empowered to take part in the decision-making process.

O incentivo para a participação da opinião pública na ciência pode ser conseguido, segundo Wagensberg, "não [...] com exposições, mas sim com atividades [...] organizadas em torno delas: conversas, palestras, seminários, cursos, debates, congressos, reuniões, discussões, mesas redondas, teatro, música, cinema..." 90 .

\subsubsection{Social}

O aspecto social dos centros de ciências inclui sua responsabilidade social, seu papel como promotor de inclusão social e as relações que se estabelecem entre os diversos grupos envolvidos.

\footnotetext{
${ }^{87}$ CHAGAS; STORINO, 2007, p. 6.

${ }^{88}$ Ibidem, p. 6.

${ }^{89}$ SANDELL, 2003.

${ }^{90}$ WAGENSBERG, 2005a, p. 5.
} 
Vamos buscar definir primeiramente exclusão social. Sandell cita diversas fontes ${ }^{91}$ ao abordar o conceito. A partir delas, podemos afirmar que exclusão social é um processo de desintegração social, que implica no isolamento, total ou parcial, de determinado indivíduo ou grupo em relação aos sistemas sociais, econômicos, políticos e culturais, e que pode acontecer em virtude de uma combinação de fatores interligados, como desemprego, baixa qualificação, baixo rendimento, condições habitacionais ruins, entorno com alta criminalidade, saúde precária, pobreza e desintegração familiar. A inclusão social é o combate à exclusão, seu oposto.

Valente, Cazelli e Alves afirmam que os museus de ciências "passaram a ter como principal missão comunicar e socializar o conhecimento" 92 , ou seja, fazer divulgação científica. Sob esse aspecto, vão abordar a questão da inclusão social. 0 mundo atual é caracterizado por mudanças constantes e rápidas, e nesse cenário, o conhecimento científico - alfabetismo científico - é muito importante para a inclusão ou inserção social. Como já vimos, os museus de ciências são importantes agentes de educação informal e divulgação científica. “Um público mais culto cientificamente estará em melhor posição para discutir, acompanhar e reivindicar políticas públicas referentes a questões atuais e controversas da ciência" ${ }^{93}$. Cazelli comenta ainda sobre a importância, para a promoção da cultura, da constituição de uma "rede de instâncias culturais", na qual os museus "vêm ocupando lugar de destaque" 94 .

Studart aponta na mesma direção quando afirma que, atualmente, "entende-se que é fundamental para a política educativa, cultural e social dos museus buscar atingir diferentes segmentos da sociedade, visando a uma maior inclusão social" 95 .

\footnotetext{
${ }^{91}$ SILVER, 1995; WALKER, 1997; DCMS, 2000, apud SANDELL, 2003.

${ }^{92}$ VALENTE; CAZELLI; ALVES, 2005, p. 194.

93 Ibidem, p. 201.

${ }^{94}$ CAZELLI, 2006, p. 1.

${ }^{95}$ STUDART, 2009, p. 95.
} 
Sandell acredita que o museu tem a possibilidade e o dever de auxiliar no combate à exclusão social / promoção da inclusão social:

It is argued here that museums and other cultural organizations have the potential to empower individuals and communities and to contribute towards combating the multiple forms of disadvantage experienced by individuals and communities described as 'at risk of social exclusion' 96 .

Segundo ele, os museus podem contribuir para a inclusão social em três níveis: individual, estimulando a auto-estima, confiança e criatividade; comunitário, agindo como catalisadores da regeneração social; e social, promovendo a tolerância e o respeito entre comunidades e desafiando estereótipos. Na Inglaterra, a política oficial para museus atribui a eles "responsabilidade social" 97 como "importantes agentes do combate à exclusão social" ${ }^{98}$. Sandell defende que, para serem mais eficazes nesse papel, os museus devem democratizar sua relação com as comunidades, desenvolvendo mecanismos através dos quais elas possam participar da tomada de decisões da instituição.

Embora as iniciativas dos museus no sentido de promover a inclusão social sejam louvadas pela maioria dos autores e por parte dos profissionais de museus, há vozes contrárias. Alguns vêm nesse papel um desvio - inadequado - das missões tradicionais do museu ${ }^{99}$. E há outras posições, bastante críticas, como a de Lopes, que apresenta a ação de inclusão social dos museus como algo

[...] não a ser afirmado, mas a ser problematizado, pois somente evidencia que mecanismos sociais de controle do saber estão agindo, no sentido de permitir ou não, a grupos sociais específicos, a incorporação desses elementos da cultura ao seu universo cognitivo ${ }^{100}$.

\footnotetext{
${ }^{96}$ SANDELL, 2003, p. 45.

${ }^{97}$ DCMS, 2000, apud SANDELL, 2003, p. 46.

98 Ibidem, p. 46.

99 SANDELL, 2003.

${ }^{100}$ LOPES, M. M., 2009, p. 206.
} 
Ela questiona também se essas instituições seriam capazes de efetivamente permitir a inclusão.

Marandino, parecendo quase responder a Lopes, comenta que "há quem postule que a divulgação científica teria o papel de manter o status quo daqueles envolvidos na produção do conhecimento" ${ }^{101}$. E complementa:

[...] para além da discussão sobre as reais intenções da divulgação da ciência, é fundamental que se promova a apropriação desses conhecimentos pela população como forma de inclusão social ${ }^{102}$.

Sob uma óptica que nos parece ainda mais ampla, Cury, defende que "A postura democrática propôs o museu como instrumento de transformação social [...]" 103 . Essa posição é compartilhada por Chagas, que afirma que os museus na atualidade são "ferramentas de intervenção social" ${ }^{104}$, devendo estar sua dimensão educativa comprometida com a "transformação social" 105.

Segundo Rodari e Merzagora ${ }^{106}$, o papel social dos centros de ciências tem ganhado cada vez mais importância como elo entre a comunidade científica e a sociedade em geral, envolvendo diversos atores sociais: sistema escolar, instituições de pesquisa, autoridades governamentais, indústria do turismo, comunidades empresariais, mercado de trabalho, associações de consumidores, agências ambientais, imprensa, etc.

Um exemplo brasileiro, que se constitui numa iniciativa prática de inclusão social é o Projeto Clicar da Estação Ciência (USP), localizada em São Paulo, no bairro da Lapa. O bairro, por sua condição geográfica estratégica e pelos serviços associados (estação de trem, linhas de ônibus, Mercado da Lapa, etc.) é um caminho usual de ligação entre a Zona Norte e o restante da cidade. Provavelmente como

\footnotetext{
${ }^{101}$ MARANDINO, 2005, p. 162.

${ }^{102}$ Ibidem, p. 162.

${ }^{103}$ CURY, 2005, p. 37.

${ }^{104}$ CHAGAS, 2002, 51.

${ }^{105}$ Ibidem, p. 52.

${ }^{106}$ RODARI; MERZAGORA, 2007.
} 
conseqüência, um grande número de crianças e jovens, percebidos como em situação de risco, visita espontaneamente a Estação. A partir dessa constatação, e não como um objetivo preestabelecido da instituição, surgiu o Clicar, "baseado na interação educador-criança e na utilização de ferramentas - computador, livros, jogos, papel, lápis, tintas - que integram ou intermedeiam essa relação" 107.

\subsubsection{Motivação}

Os centros de ciência podem também contribuir para modificar a noção de que a ciência seja difícil e pouco interessante, e que seja uma área pouco atraente para o jovem desenvolver sua atuação profissional.

“É um mal-entendido se pensar que a ciência é uma forma de conhecimento especialmente difícil. [...] A ciência é objetiva, inteligível e dialética. A ciência que não se pode transmitir não é ciência" ${ }^{108}$. Wagensberg entende que a motivação, ou o "incentivo", é que constituem o real objetivo do centro de ciências. "Mas qual é a verdadeira função do museu? Qual a sua função ideal, o que é que ele faz melhor do que qualquer outro sistema? A resposta para essa pergunta [...] [é] estímulo" 109. Essa idéia é tão forte em Wagensberg, que é central na sua definição de museu de ciências: “[...] é um espaço dedicado a fornecer um estímulo para o conhecimento científico, o método científico e a opinião científica"110.

Outros autores parecem concordar com essa idéia de Wagensberg. Maurício afirma que o museu de ciências "pode propiciar experiências enriquecedoras para as crianças, aumentando o contingente dos potencialmente estimulados" 111 e Raw, ao mesmo tempo em que dá pouco crédito ao aspecto diretamente educativo dos

\footnotetext{
${ }^{107}$ PRANZETTI; COSTA, 2001, p. 186.

${ }^{108}$ WAGENSBERG, 2003.

${ }^{109}$ Idem, 2005a, p. 3.

110 Ibidem, p. 1.

${ }^{111}$ MAURÍCIO, 1992, p. 26.
} 
centros de ciências, destaca que "Essas instituições entusiasmam o público que as freqüenta, conferem dinamismo ao aprendizado da ciência" ${ }^{112}$.

McManus destaca como características dos centros de ciências "um desejo de atrair os jovens para o estudo formal de assuntos científicos, o divertimento, o entusiasmo $[\ldots]^{\prime 113}$.

Conforme comentado anteriormente, a partir da década de 1960 os museus passaram a se concentrar na "difusão de princípios científicos e tecnológicos, a fim de induzir os jovens às carreiras pertinentes a essas áreas" ${ }^{114}$.

Wellington defende a tese de que os centros de ciência normalmente contribuem apenas para o conhecimento dos fatos ou fenômenos, mas não do seu funcionamento ou de suas causas. Por outro lado, indiretamente eles compensam essa deficiência, desencadeando processos que vão gerar frutos mais tarde, pois contribuem para o desenvolvimento de "entusiasmo, motivação, vontade de aprender, consciência" 115 - fatores que podem mesmo acabar por proporcionar o entendimento dos fenômenos.

Wagensberg afirma que “Um bom museu está baseado em emoções, e as emoções são iguais para os jovens, para qualquer pessoa" ${ }^{116}$.

Esse papel do museu como motivador está mais próximo da fruição, das experiências de fluência e do processo da ciência, conforme definidas anteriormente no capítulo.

\footnotetext{
112 RAW, 1998, p. 75.

113 MCMANUS, 2009, p. 56.

${ }^{114}$ Ibidem, p. 189.

${ }^{115}$ WELLINGTON, 1990, p. 250. Tradução nossa.

${ }^{116}$ WAGENSBERG, 2003.
} 


\subsubsection{Lazer}

O lazer, o divertimento, também faz parte dos objetivos do museu, sendo citado nos textos de diversos autores ${ }^{117}$.

Studart se refere aos centros de ciências como "uma valiosa opção de lazer" 118 enquanto Dierking afirma que várias pesquisas sugerem que "muitas famílias consideram museus e centros de ciências como lugares onde elas podem aproveitar bem seu tempo" ${ }^{119}$. Chagas se refere à "ampliação de ofertas de lazer qualificado" 120. Marandino, com relação às exposições dos museus de ciências, afirma que elas devem "proporcionar momentos de prazer e deleite, ludicidade e contemplação" ${ }^{121}$. Segundo Chelini e Lopes, "Georges Henri Rivière estabelece que o museu é um meio de comunicação e que, independente do tipo de exposição, a museografia deve proporcionar um aporte de prazer e conhecimento" 122.

Guisasola, Morentin e Zuza ${ }^{123}$ dão ênfase ao aspecto educacional do museu, e vêm no divertimento ${ }^{124}$ não um colaborador, mas um competidor da educação museal. Conforme visto anteriormente (tópico 2.1.1), eles defendem um processo mais regrado para a visita aos museus de ciência, que garantiria melhor eficácia ao aprendizado desenvolvido no local. Os autores citam algumas características negativas geralmente atribuídas aos centros de ciências, que parecem refletir seu próprio pensamento: banalização da ciência ao priorizar o divertimento; ênfase em idéias "espetaculares" em detrimento de objetivos educacionais; maior sucesso no aspecto de lazer do que no educacional. Por outro lado, os autores admitem que os

\footnotetext{
${ }^{117}$ MCMANUS, 2009; STUDART, 2009; DIERKING, 2009; CHAGAS, 2002; MARANDINO, 2005; SCHAUBLE; BARTLETT, 1997; PADILLA, 2001; BALDACCI, 2001; CRESTANA, 2001; CHELINI; LOPES, 2008.

${ }^{118}$ STUDART, 2009, p. 115.

${ }^{119}$ DIERKING, 2009, p. 79.

${ }^{120}$ CHAGAS, 2002, p. 56.

${ }^{121}$ MARANDINO, 2005, p. 163.

${ }^{122}$ CHELINI; LOPES, 2008, p. 207.

${ }^{123}$ GUISASOLA; MORENTIN; ZUZA, 2005.

${ }^{124}$ No original, "fun" e "entertainment".
} 
objetivos dos museus de ciências não são exclusivamente educacionais, mas abrangem também cultura, desenvolvimento pessoal, atitudes e socialização.

A espetacularização das exposições é um perigo ao qual devemos estar atentos. Na segunda metade do século $X X$, num momento em que a cultura de massa está se consolidando e o cinema hollywoodiano invade a Europa, Debórd define o conceito de espetáculo. Nele "estão contidas as idéias fundamentais de Debórd sobre a sociedade contemporânea: a separação, o afastamento do mundo vivido em imagens que o representam [...]" ${ }^{125}$. O essencial nesse conceito é a transformação do indivíduo em espectador, passivo, alienado, com “a substituição das vivências diretas $[\ldots]$ pelo consumo passivo de imagens" ${ }^{126}$. O espetáculo é o meio através do qual isso acontece. Posteriormente, Jean Baudrillard desenvolveu a "[...] teoria do simulacro [...], que é ancorada na idéia de que o real é substituído por imagens $[\ldots]^{\prime \prime} 127$.

Além do estudo geral de fenômenos científicos e instrumentos tecnológicos, alguns outros temas têm sido apresentados nos centros de ciências. Trata-se de exposições fortemente relacionadas à cultura de massa, chamadas de blockbuster exhibition, ou exposição arrasa-quarteirão. Ela é definida por Fleming ${ }^{128}$ como “uma exposição espetacular que atrai grandes multidões e provavelmente custa muito dinheiro para ser produzida e para ser visitada". Ainda que o termo "espetacular" possa ter sido empregado pelo autor no seu sentido vulgar, nãodebordiano, ele nos dá uma pista de que essas exposições são particularmente suscetíveis à espetacularização e a promover a alienação a ela associada.

Segundo Menezes, “[...] os museus podem ter um lugar certo [...] na cultura como espetáculo [...]" ${ }^{129}$, e as exposições arrasa-quarteirão "só podem guiar-se pelas

\footnotetext{
${ }^{125}$ BELLONI, 2003, p. 131.

${ }^{126}$ FRIDMAN, 1998, p. 2. Numeração nossa.

${ }^{127}$ Ibidem, p. 4. Numeração nossa.

${ }^{128}$ FLEMING, 2004, p. 1. Numeração e tradução nossa.

${ }^{129}$ MENEZES, 2006, p. 60.
} 
regras e finalidades do mercado" ${ }^{130}$, o que significa, essencialmente, a maximização do lucro, e não necessariamente a conscientização do público visitante sobre assuntos científicos ou culturais.

Filmes de grande sucesso comercial ao redor do mundo, como as trilogias de $\mathrm{O}$ Senhor dos Anéis e Guerra nas Estrelas estão normalmente vinculados às exposições blockbusters e à questão do divertimento. Louise Jury ${ }^{131}$, em artigo de jornal de 2003, dá voz a pontos de vista diversos sobre o assunto, considerando o contexto britânico. O antigo diretor do museu de Glasgow, Julian Spalding, não acredita ser legítimo uma instituição pública hospedar uma exposição apenas para aumentar sua visitação. David Barrie, do National Art Collections Fund afirma que os museus estão sendo pressionados por dinheiro, tendo de demonstrar ao governo que estão recebendo grandes públicos, correndo o risco de "distorcer o planejamento normal de exibições". I van Massow, antigo presidente do Institute of Contemporary Arts defende que o problema é que o governo não investe adequadamente em cultura, arte e museus, o que força as instituições a se tornarem mais "comerciais".

Fleming ${ }^{132}$ aponta a superficialidade e a falta de relevância de algumas exposições, assim como a fraca experiência do visitante em razão da superlotação decorrente da grande atração de público.

J on Tucker era o diretor do South Kensington Science Museum, em 2003, quando o museu abrigou uma exposição sobre a trilogia de O Senhor dos Anéis. No artigo de Louise Jury ${ }^{133}$ ele defende sua exposição argumentando que ela estaria totalmente relacionada com "as várias tecnologias da indústria cinematográfica e parte da tecnologia é absolutamente revolucionária". A exposição seria também uma forma de atrair um público que normalmente não iria a um museu de ciências, e que, uma

\footnotetext{
${ }^{130}$ MENEZES, 2006, p. 59.

${ }^{131}$ JURY, 2003.

${ }^{132}$ FLEMING, 2004, p. 2-4. Numeração nossa.

${ }^{133}$ JURY, 2003.
} 
vez conhecendo o espaço, normalmente o acha muito mais interessante do que esperava. Jill Nelson, do British Association for the Advancement of Science, entende que a atração de um novo público é legítima, mas destaca que os cientistas estão divididos sobre o equilíbrio entre a popularização e a banalização da ciência.

Fleming ${ }^{134}$ aponta alguns aspectos positivos das exposições arrasa-quarteirão. Elas atraem cobertura dos meios de comunicação, patrocinadores e, em sendo lucrativas, podem financiar outras atividades ou exposições importantes mas que apresentam menor poder de atração de recursos. Em particular esse último aspecto, segundo ele, justificaria a realização desse tipo de exposição.

\subsubsection{Impacto Urbano}

Os centros de ciências são equipamentos urbanos relevantes, com impacto no seu entorno. Rodari e Merzagora ${ }^{135}$ destacam a presença física do museu, que inclui os visitantes, como uma característica única dentre as mídias relacionadas à ciência, e que favorece que se tornem "agentes territoriais" ${ }^{136}$, associados a projetos de transformação urbana e atuando como pólos de agregação.

O Centro Georges Pompidou constituiu-se no marco de uma "nova estratégia de implantação de equipamentos culturais como âncoras nos processos de requalificação urbana" ${ }^{137}$. Foi inaugurado em 1977 com papel central na intervenção sobre Les Halles, na área central de Paris. Diversos são os exemplos de ações desse tipo consideradas bem-sucedidas: o Museu Guggenhein, em Bilbao,

\footnotetext{
${ }^{134}$ FLEMING, 2004, p. 1-2. Numeração nossa.

${ }^{135}$ RODARI; MERZAGORA, 2007, p. 1.

${ }^{136}$ No original, "territorial agencies".

${ }^{137}$ MOTTA, 2009, p. 26.
} 
Espanha ${ }^{138}$, o newMetropolis / Nemo em Amsterdã, Holanda, a Cité des Sciences et de l'Industrie / Parc de la Villette em Paris, França, entre outros.

Atualmente há grande ênfase nas formas como o museu interage com outros agentes sociais, sendo um desses agentes a indústria do turismo ${ }^{139}$.

Menezes, entretanto, destaca um fato potencialmente negativo da utilização do museu como agente de transformação urbana. A introdução de "critérios e objetivos do mercado", que já se dá, por exemplo, através das exposições arrasaquarteirão, pode ter como seqüência a “mobilização dos museus para estratégias de city selling, como se fosse em si, sempre e em qualquer circunstância, um recurso válido de requalificação urbana" ${ }^{140}$.

Os diversos objetivos dos centros de ciências listados no capítulo não são categorias isoladas. A educação e a divulgação científica estão intimamente ligadas. Vários são os artigos cujos títulos contêm ambas as expressões, e que em nenhum momento ao longo do texto as diferenciam, sendo a definição dessas expressões algo não consensual. O debate e a participação são possíveis quando associados à divulgação e à educação: não é possível debater sobre o que não se conhece. $\mathrm{A}$ inclusão social pode acontecer associada aos diversos outros objetivos, incluindo a motivação.

\footnotetext{
${ }^{138}$ FABIANO JUNIOR, 2009, p. 161 e 164.

${ }^{139}$ RODARI; MERZAGORA, 2007, p. 1.

${ }^{140}$ MENEZES, 2006, p. 59.
} 


\subsection{Público-alvo}

A tendência contemporânea é de priorizar o público em sua relação com o museu, assumindo-o “como ator central no processo de comunicação" ${ }^{141}$, o que inclui a preocupação de entender melhor esse público - eventualmente através de pesquisas -, de forma a poder produzir exposições e atividades melhor adaptadas a ele ${ }^{142}$. Os indivíduos e os grupos coletivos apresentam particularidades como, por exemplo, os diferentes estilos de aprendizado que utilizam ${ }^{143}$. A heterogeneidade do público implica na responsabilidade do museu em lidar o tempo todo com "múltiplas audiências para suas comunicações" 144.

Considerando-se essa heterogeneidade, pode-se colocar a questão mais específica do público-alvo dos museus:

Os museus têm potencial para oferecer oportunidades educacionais para pessoas de todas as idades, formações, habilidades, classes sociais e etnias. No entanto, será necessário decidir qual (ais) público(s)-alvo(s) se deseja atingir a curto- prazo $^{145}$.

Enquanto a visão acima prioriza a escolha de um grupo específico no curto prazo, a ênfase de Wagensberg é na generalização. “Uma das nossas hipóteses de trabalho é que a audiência de um museu é universal, não depende da idade, da formação cultural ou do nível econômico de seus visitantes, nem do lugar onde está situado" 146. Entretanto, acrescenta em outro texto que "é exatamente por isso que precisamos conhecer o nosso público profundamente, para que possamos saber, em particular, quem está faltando e qual o setor social está ficando de fora" ${ }^{147}$.

\footnotetext{
${ }^{141}$ MARANDINO, 2008, p. 16.

142 Ibidem; CURY, 2005; WITSCHEY, 2006.

${ }^{143}$ SERREL, 1990.

${ }^{144}$ MCMANUS, 2009, p. 55.

${ }^{145}$ MUSEUMS, 2001b, p. 18.

${ }^{146}$ WAGENSBERG, 2003.

${ }^{147}$ Idem, 2005a, p. 18.
} 
Conhecer o público significa também entender como ele usa a tecnologia no seu dia a dia, e como ele utiliza o museu - o que pode ser feito através de pesquisas ${ }^{148}$. As inovações tecnológicas das últimas décadas e sua influência nos museus serão discutidas no Capítulo 3.

As atividades dos museus contemporâneos são escolhidas de forma a permitir uma participação muito mais ativa do público. São espaços para debates; apresentação de posturas discordantes de forma a que o público possa refletir e se posicionar; oficinas sobre os temas da exposição; expedições, viagens e fóruns; "conferências de consenso" ${ }^{149}$. Essas tendências são reações ao modelo tradicional, passivo, no qual o museu seleciona, recorta e apresenta conteúdos a um público visto como indistinto e meramente receptor de informações. Marandino ${ }^{150}$ defende a importância de se mesclar os processos tradicionais, passivos, com os novos processos participativos.

Ocorreu também, nas últimas décadas, uma ampliação do conceito de público nos museus, que passou de visitante a usuário ${ }^{151}$. O público não se restringe àquele que entra fisicamente no museu (o visitante), mas inclui todos aqueles usuários que utilizam algum serviço do museu, como, por exemplo, encomenda de livros ou outros materiais, visitas a exposições itinerantes e participação em ações pedagógicas nas escolas. Essa diferença se dá no espaço. Outra distinção se dá no tempo: entre o público real ou efetivo (que já visitou ou utilizou o museu) e o público potencial (que possui características que o possibilita vir a se tornar público efetivo).

A esse novo conceito de público está associada também uma nova postura com relação à avaliação do museu, na qual:

\footnotetext{
${ }^{148}$ WITSCHEY, 2006.

${ }^{149}$ MARANDINO, 2008, p. 17.

150 Ibidem.

${ }^{151}$ MOREIRA, 2007.
} 
[...] é necessário adicionar, não só o número de pessoas que, de alguma maneira, interagiram diretamente com o museu e os resultados que daí retiraram, mas também todas aquelas que se beneficiaram, de alguma forma, da sua ação (mesmo indiretamente) e o tipo de benefícios produzido ${ }^{152}$.

Como vimos, pode-se enfatizar a abordagem de um público alvo focado ou generalizado. Qualquer que seja a ênfase, é necessário conhecer melhor esses públicos. Eles não são homogêneos, e podemos dizer "que existem diferentes tipos de público que se tornam um grupo apenas se possuírem características que os agrupem de alguma maneira" ${ }^{153}$. Marandino ${ }^{154}$ propõe a classificação nos seguintes grupos: a) Escolares (estudantes e professores); b) Famílias; c) Público especializado ("artistas, críticos, cientistas, acadêmicos e estudantes de graduação"); d) Grupos organizados de terceira idade; e) Portadores de necessidades especiais; f) Grupos oriundos de ONG, associações, sindicatos e clubes diversos.

A maioria dos autores dá especial atenção aos dois primeiros grupos, que serão tratados a seguir: os grupos de famílias e os grupos escolares.

\subsubsection{Famílias}

White ${ }^{155}$, em texto de 1990, afirma que o público mais comum em "Salas de descoberta" ${ }^{156}$ são as famílias - adultos com crianças. É necessário ressalvar que ela escreve a partir do contexto norte-americano, o que pode não corresponder à realidade brasileira. Esses grupos de famílias prefeririam atividades interativas

\footnotetext{
${ }^{152}$ MOREIRA, 2007, p. 107.

153 MARANDINO, 2008, p. 24.

154 Ibidem.

${ }^{155}$ WHITE, 1990.

${ }^{156}$ Ibidem. Salas de descoberta (no original, “discovery rooms”) podem ser definidas como salas com caixas de atividades para exploração manual ("hands-on”), interativa, planejadas para propiciar “aprendizado informal”.
} 
hands- on ${ }^{157}$, sendo fundamental também a interação social entre os seus membros $^{158}$.

Os adultos escolhem o museu para a visita com o intuito de proporcionar às crianças um lazer com qualidade cultural. Os pais tentam facilitar o aprendizado dos filhos, mas podem, nesse processo, acabar também aprendendo com eles ${ }^{159}$.

Ou seja, os adultos também são beneficiados. Ab'Sáber afirma que, apesar de os museus de ciências normalmente terem os jovens como público alvo, eles podem ser importantes "para a educação ou reeducação de adultos" ${ }^{160}$. E Gaspar constata que "muitos adultos são vistos em museus de ciências envolvidos animadamente com experimentos concebidos para crianças" ${ }^{161}$.

Segundo Studart ${ }^{162}$, as visitas de grupos familiares aos museus são importantes fatores para a formação do público futuro dessas instituições, visto que elas são talvez a principal influência para o hábito de visita das crianças quando em idade adulta. Essa postura é praticamente idêntica à de Dierking ${ }^{163}$.

Em outro texto, Studart chama a atenção para a peculiaridade do grupo familiar:

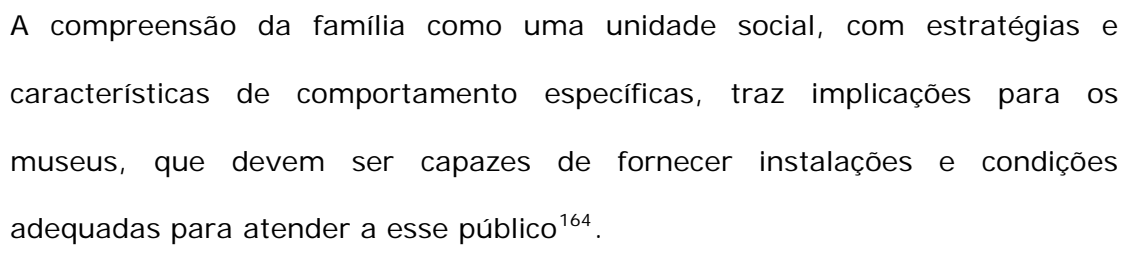

Os espaços devem propiciar um entorno social onde os membros da família possam estar juntos e compartilhar as atividades ${ }^{165}$.

\footnotetext{
${ }^{157}$ De manipulação com as mãos.

${ }^{158}$ O tema Interatividade será discutido no Capítulo 3.

159 STUDART, 2009.

160 AB’SÁBER, 1998, p. 27.

${ }^{161}$ GASPAR, 1993, Capítulo IV - Item 3.5 - Os centros de ciências e as teorias de aprendizagem.

162 Ibidem.

${ }^{163}$ DIERKING, 2009.

${ }^{164}$ STUDART, 2003, p. 34.

165 Idem, 2009.
} 
Segundo Dierking, "o primeiro grupo de aprendizagem com o qual uma pessoa colabora é a sua própria família" ${ }^{166}$. As famílias têm estilos de aprendizagem diferentes nos museus. Algumas funcionam de forma mais independente, com os indivíduos se encontrando de vez em quando para dividir as experiências. Mas, de forma geral, "os tipos mais eficazes de experiências para famílias nos centros de ciências [...] são aqueles que promovem e facilitam a interação e a colaboração social" 167 .

Essa aprendizagem pode ser bem sucedida:

As pesquisas sugerem que os museus aumentam a disposição e o interesse das famílias e têm a capacidade de facilitar-lhes o entendimento de ampla gama de conceitos complexos, inclusive tópicos científicos ${ }^{168}$.

O público de famílias está associado à chamada "aprendizagem de livre escolha" 169, que é definida como "auto-dirigida, voluntária e guiada pelas necessidades e interesses de quem aprende $[\ldots]$ ao longo de toda a vida" ${ }^{170}$. Essa aprendizagem é considerada por Dierking também como uma atividade de lazer, turismo cultural com valor agregado - uma atividade econômica cada vez mais relevante ${ }^{171}$. Essa visão é reforçada, se levarmos em conta que

[...] as crianças indicaram que, muitas vezes, preferem visitar os museus com suas famílias e não com sua escola, porque conseguem olhar mais as coisas que pessoalmente Ihes interessam e conversar, com seus pais e irmãos, sobre o que estão fazendo e observando ${ }^{172}$.

Pesquisas brasileiras e estrangeiras indicam que a maioria dos adultos das famílias que visitam museus tem nível superior ${ }^{173}$. Entretanto, é importante atingir

\footnotetext{
${ }^{166}$ DIERKING, 2009, p. 79.

${ }^{167}$ Ibidem, p. 80.

168 Ibidem, p. 83.

${ }^{169}$ Ibidem, p. 77. A expressão é a tradução do autor para free-choice learning.

${ }^{170}$ Ibidem, p. 77.

${ }^{171}$ Ibidem.

172 JENSEN, 1994, apud DIERKING, 2009, p. 80.

173 STUDART, 2009.
} 
diferentes públicos, de diferentes segmentos da sociedade, como forma de favorecer a inclusão social ${ }^{174}$. Nesse sentido, alguns museus têm mantido programas cujo objetivo é "a construção [...] [de] relacionamentos de longo tempo com famílias, especialmente aquelas de novas comunidades" ${ }^{175}$.

\subsubsection{Escolas}

A visita ao museu através da escola é também muito importante, principalmente para as camadas sociais mais baixas. "No Brasil, pesquisas mostram que, na maioria das vezes, é somente por meio da escola que crianças e jovens das classes em desvantagens econômicas visitam as instituições culturais" ${ }^{176}$.

É importante estabelecer uma parceria entre as instituições - museu e escola - que favoreça, por parte dos alunos, uma atitude positiva com relação aos museus e uma "prática autônoma de visita" 177. Para isso, é fundamental a adequada formação dos educadores de ambas as instituições. Os professores das escolas devem receber formação "nas linguagens e práticas específicas do espaço museal" 178 enquanto os educadores dos museus devem entender os "objetivos e necessidades das escolas ao visitarem o espaço museal" ${ }^{179}$.

Em termos de visitação, os grupos escolares apresentam participação percentual diferente no Brasil e no exterior, tomando-se dados da década de 1990. Correspondem a cerca de um terço do total no Brasil ${ }^{180}$ e estão na faixa de $10 \%$ e $20 \%$ do total nos Estados Unidos ${ }^{181}$.

\footnotetext{
${ }^{174}$ STUDART, 2009.

175 ADELMAN, DIERKING, ADAMS; LUKE, DIERKING, 2000 apud DIERKING, 2009, p. 85.

${ }^{176}$ MARANDINO, 2008, p. 24.

${ }^{177}$ Ibidem, p. 25.

178 Ibidem, p. 25.

${ }^{179}$ Ibidem, p. 25.

${ }^{180}$ CURY, 2000.

${ }^{181}$ ANDERSON, 1991,
} 
Também a partir do contexto norte-americano, Hensley ${ }^{182}$ afirma que os programas de centros de ciências focalizam prioritariamente os alunos da faixa correspondente ao Ensino Fundamental I, e quase não oferecem atividades para os estudantes do Ensino Médio ${ }^{183}$, considerando que focando os mais novos obter-se-á melhores resultados, pois eles ainda estão decidindo o que pensam de ciência:

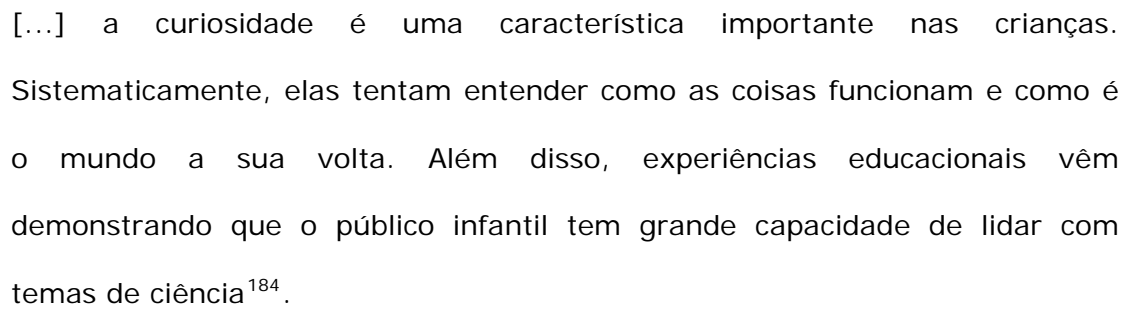

Os grupos familiares vão aos centros de ciências buscando lazer e aprendizado. As visitas escolares têm objetivos educacionais e podem ter impacto muito relevante para os alunos de classes sociais mais baixas, que dificilmente vão a essas instituições com suas famílias. Em ambos os casos, as idas ao museu podem contribuir para a formação do público futuro das instituições, favorecendo o hábito de visita das crianças quando em idade adulta. A inclusão social pode ser o foco em situações especiais, como, por exemplo, através de programas de incentivo à visitação de famílias de novas comunidades.

\footnotetext{
${ }^{182}$ HENSLEY, 1991.

${ }^{183}$ Comparando as estruturas de ensino brasileira e americana, consideramos o Ensino Fundamental I correspondendo às elementary school classes, e o Ensino Médio ao high school.

${ }^{184}$ MASSARANI, 2005, p. 7.
} 


\section{CONCEITOS COMPLEMENTARES}

3.1 Novas tecnologias e seu impacto nos museus

Em 1994, Pierre Lévy já preconizava a constituição do ciberespaço como ‘o
novo espaço de funcionamento da Humanidade' - uma nova instância de
comunicação e de pensamento, que faria emergir um espaço dinâmico de
subjetividade coletiva [...]. Hoje vivenciamos plenamente esta realidade [...]
1 .

Enquanto Lévy vê no ciberespaço "novas [...] formas de sociabilidade, prenunciadoras de um futuro de sonhos" 2, Jean Baudrillard, por outro lado, entende o virtual como a eliminação do social.

De qualquer forma, é impossível negar o impacto do surgimento da internet. Ela transformou o modo como as pessoas lidam com a informação, que atualmente esperam sempre contar com acesso instantâneo à mesma ${ }^{3}$. Mas a rede mundial de computadores não foi a única inovação tecnológica dos últimos tempos. Os telefones celulares foram inventados e popularizados, surgiram notebooks e computadores de mão, que mais tarde se fundiram com os celulares, gerando os smartphones, com acesso integral à internet. Mais recentemente surgiram os tablets.

Essas novas tecnologias foram sendo absorvidas pelos museus, que passaram a utilizá-las para interagir com o visitante ${ }^{4}$, tanto oferecendo informações complementares (textos, imagens, links) como coletando informações do público ${ }^{5}$, o que possibilitou também a criação de websites personalizados que o visitante pode acessar fora do ambiente do museu.

\footnotetext{
${ }^{1}$ SCHEINER, 2007, p. 34.

${ }^{2}$ MENEZES, 2007, p. 63-64.

${ }^{3}$ WITSCHEY, 2006, Capítulo II - Trend 1: Instant Information Access.

${ }^{4}$ Ibidem, Capítulo II - Trend 1: Instant Information Access.

${ }^{5}$ Ibidem, Capítulos III - Trend 2: Customization e VIII - Trend 7: Learning About Learning.
} 
Se, num primeiro momento, a tendência dos museus era de fornecer equipamentos próprios aos visitantes (como os reprodutores de áudio com fones de ouvido, que funcionam como guias eletrônicos), com a popularização das novas tecnologias, cada vez mais o usuário utiliza seu próprio equipamento, aliviando o museu de custos logísticos e de manutenção ${ }^{6}$.

A utilização da internet pelos museus pode se dar de maneiras diferentes, em menor ou maior plenitude. A forma mais simples é a do '“folheto eletrônico', que [...] funciona como um espaço de publicidade, apresentando a instituição e informando sobre seus horários e sua programação" 7 . Em seguida vem a disponibilização de acervos e reservas técnicas de museus ou exposições existentes no "mundo real" no meio digital ${ }^{8}$. A terceira categoria é a das exposições ou museus no ciberespaço que não são reproduções de outros existentes no mundo físico ${ }^{9}$, e nas quais os visitantes podem "interagir com as imagens para além da observação" ${ }^{10}$.

Nos anos 2000, com o surgimento e disseminação dos blogs e redes sociais, também esses recursos passaram a ser explorados pelos museus, que os utilizam como forma de conquistar o seu público para ações mais participativas e de forma continuada, em atividades ligadas à ciência num nível mais elevado ${ }^{11}$.

Segundo Scheiner, "o que efetivamente importa no universo virtual $[\ldots]$ é $[\ldots]$ buscar compreender de que modos e formas este novo aparato interfere nas relações entre as pessoas, ou entre humanos e o mundo", destacando seu viés comunicacional, sua "capacidade de interligar as pessoas" ${ }^{12}$.

\footnotetext{
${ }^{6}$ WITSCHEY, 2006, Capítulo IV - Trend 3: New Communication Networks.

${ }^{7}$ GOUVEIA; DODEBEI, 2007, p. 96.

${ }^{8}$ SCHEINER, 2007, p. 45; e GOUVEIA; DODEBEI, 2007, p. 96-97.

${ }^{9}$ Ibidem, p. 45; e GOUVEIA; DODEBEI, 2007, p. 97.

${ }^{10}$ GOUVEIA; DODEBEI, 2007, p. 97.

${ }^{11}$ WITSCHEY, 2006, Capítulos V - Trend 4: Participation and Personal Expression e VI - Trend 5:

Making Science Accessible.

${ }^{12}$ SCHEINER, 2007, p. 34.
} 
Um outro aspecto a se considerar é a maneira através da qual as crianças e os jovens da atual geração podem ser envolvidos nas atividades dos museus, visto que estão já habituados com recursos tecnológicos inimagináveis para as gerações anteriores ${ }^{13}$. Ou seja, os encaram com naturalidade, e tem um padrão elevado de exigência para se envolver nessas atividades, que deve ser atendido ou pode comprometer sua efetiva participação.

Uma das formas que tem sido utilizada para fomentar esse envolvimento da geração atual de crianças e jovens é a realidade virtual, "verdadeiros universos simulados, inspirados no real" ${ }^{14}$, mundos gerados "a partir de uma relação homem-máquina, um mundo criado artificialmente, que o usuário pode 'habitar'. No início, 'apenas' mentalmente... e visualmente; mas a meta é envolver todos os sentidos" 15 .

Menezes descreve a realidade virtual como

$$
\begin{aligned}
& \text { uma técnica de apresentação e produção da imagem que privilegia a } \\
& \text { tridimensionalidade [...]. Um capacete (por enquanto) produz o efeito } \\
& \text { estereoscópico semelhante ao que nossos dois olhos fazem com a imagem de } \\
& \text { retina dos objetos reais. [...] Produz-se um espaço não atual, ilusório, } \\
& \text { potencial (é o que quer dizer virtual: o que existe não em ato, mas como } \\
& \text { possibilidade) }{ }^{16} \text {. }
\end{aligned}
$$

É interessante que essa imagem da realidade virtual associada a um capacete especial que se relaciona com aos primeiros momentos dessa técnica parece não ter prevalecido. A esse sistema individual se sobrepôs o sistema coletivo: as salas imersivas onde o efeito estereoscópico se dá nas telas de projeção ou nas mais recentes TVs digitais 3D, com a substituição do capacete por um par de óculos especial. O cinema 3D, que surgiu em meados do século $X X$, mas foi sendo abandonado e visto como moda passageira, renasceu com força total e qualidade

\footnotetext{
${ }^{13}$ BALDACCI, 2001, p. 333.

${ }^{14}$ SCHEINER, 2007, p. 35.

${ }^{15}$ MENEZES, 2007, p. 60.

${ }^{16}$ Ibidem, p. 60.
} 
técnica excepcional no início do século XXI, prevalecendo nas produções de desenhos animados do circuito comercial, e marcando presença também nos filmes "blockbuster" com personagens de carne e osso.

Nesse momento é importante discutir alguns conceitos que estão diretamente associados a essas novas tecnologias, como a própria idéia de virtual, de museu virtual, e o imaterial.

Segundo Deleuze, "o virtual seria uma parte do real" ${ }^{17}$, e o "possível" seria a outra parte. “O virtual representa a problemática, a porção que carece de uma resolução ou, segundo Deleuze, de uma 'atualização'. [...] Em contrapartida, o possível é a porção pronta, acabada, predeterminada" ${ }^{18}$. Menezes afirma que virtual é "o que existe não em ato, mas como possibilidade" ${ }^{19}$, concepção coerente com a de Lévy $^{20}$, mais direta e que parece servir melhor à definição de museu virtual.

Para se falar em museu virtual não basta digitalizar o acervo. Nem mesmo disponibilizar esse acervo digitalizado no website do museu, o que constitui apenas uma virtualização, um processo. “[...] o virtual diz mais respeito à própria tipologia do museu, da composição física de seu acervo e da especificidade das suas exposições" ${ }^{21}$. O museu ou a exposição efetivamente virtual seria aquela "que jamais poderia ser feita fora do contexto da simulação virtual" ${ }^{22}$, e que, portanto, tende a explorar as possibilidades específicas da virtualidade. Corresponde à terceira categoria de utilização da internet, conforme citado anteriormente. Segundo Gouveia e Dodebei, "essa nova categoria não se opõe ao museu formalmente constituído, mas pode representar uma ampliação espacial desse tipo

\footnotetext{
${ }^{17}$ GOUVEIA; DODEBEI, 2007, p. 94.

${ }^{18}$ Ibidem, , p. 94.

${ }^{19}$ MENEZES, 2007, p. 60.

${ }^{20}$ LÉVY, 2005, p. 47, apud GOUVEIA; DODEBEI, 2007, p. 94.

${ }^{21}$ GOUVEIA; DODEBEI, 2007, p. 96.

${ }^{22}$ Ibidem, p. 99.
} 
de instituição" ${ }^{23}$. A grande questão ainda por ser debatida é se "museu virtual deve operar com a mesma lógica de salvaguarda dos museus concretos" 24.

Menezes tem uma visão menos otimista:

\begin{abstract}
Falar de museu virtual não significa apenas referir-se ao uso de recursos de informática, suplementando, enriquecendo ou diversificando seus procedimentos tradicionais, mas está em causa a própria substituição ou, no mínimo, a dependência desses procedimentos com relação à imagem virtual ${ }^{25}$.
\end{abstract}

Ele cita vários exemplos de museus virtuais existentes, com diversas características: recriação do contexto espacial do museu, exibição de memórias como artefatos, jogos interativos, visitas virtuais, preservação virtual de ambientes históricos (como os campos de concentração nazistas de Birkenau e Auschwitz), coleta de informações dos visitantes para produção de exposições virtuais ${ }^{26}$.

Segundo ele, na "cultura do espetáculo" a imagem virtual "não mais procura representar o real, mas modelizá-lo" ${ }^{27}$. A desmaterialização "favorece os mecanismos de dominação" ${ }^{28}$ e, por isso mesmo, "o capitalismo passa a privilegiar o imaterial e o simbólico" 29. Entretanto, Menezes ressalta que o oposto da desmaterialização, a fetichização, "que desloca os significados das coisas de sua produção para as coisas elas próprias, como se fossem atributos imanentes" ${ }^{30}$, também é indesejável - e é prática comum nos museus tradicionais.

Scheiner, entretanto, vê a relação entre o imaterial e as novas tecnologias de forma bem mais positiva, quando afirma que o "universo digital e patrimônio imaterial representam, hoje, uma poderosa instância de convergência" ${ }^{31}$, com as novas

\footnotetext{
${ }^{23}$ GOUVEIA; DODEBEI, 2007, p. 95.

${ }^{24}$ Ibidem, p. 99.

${ }^{25}$ MENEZES, 2007, p. 60.

${ }^{26}$ Ibidem, p. 61.

${ }^{27}$ Ibidem, p. 53.

${ }^{28}$ Ibidem, p. 58.

${ }^{29}$ Ibidem, p. 58.

${ }^{30}$ Ibidem, p. 58.

${ }^{31}$ SCHEINER, 2007, p. 47.
} 
tecnologias servindo para documentar o patrimônio imaterial ${ }^{32}$. Ela vê a informação como "o verdadeiro patrimônio na contemporaneidade" 33 , pois é "ela que influencia os mecanismos de memória e, de certa forma, dirige o esquecimento" ${ }^{34}$. Também a UNESCO reconhece a importância das "referências culturais imateriais" 35.

Entretanto, o excesso de informação tende a se tornar ruído ${ }^{36}$, e o conhecimento não é conseqüência natural do acúmulo de "quantidades infinitas de informação" ${ }^{37}$. "Ainda que as redes digitais permitam a criação de ambientes comunicacionais mais democráticos, permitem também a geração de uma enorme quantidade de produtos triviais e de baixa qualidade" ${ }^{38}$.

Menezes afirma que

a cibernética se introduziu no museu não como recurso para caucionar e reforçar sua especificidade (que é a de operar com segmentos do universo material em que estamos profundamente imersos), não como instrumento alternativo de ação, mas como geradores de uma nova personalidade, chave que tornaria obsoleto tudo o que até então constituíra um referencial para nossa percepção ${ }^{39}$.

Mesmo os maiores benefícios normalmente apontados pelos defensores do virtual a ampliação do acesso e a interatividade - são questionados por Menezes. Com relação à primeira ele afirma que nas atuais condições sociais não se pode falar em "democratização cibernética do museu" nem em "inclusão digital" - ambas condições necessárias para a ampliação do acesso ${ }^{40}$.

\footnotetext{
${ }^{32}$ SCHEINER, 2007, p. 46.

33 Ibidem, p. 40.

${ }^{34}$ Ibidem, p. 40.

${ }^{35}$ Ibidem, p. 47.

${ }^{36}$ BITTENCOURT, 2006, p. 20.

${ }^{37}$ Ibidem, p. 20.

${ }^{38}$ SCHEINER, 2007, p. 37.

${ }^{39}$ MENEZES, 2007, p. 61.

${ }^{40}$ Ibidem, p. 61-62.
} 
Já a interatividade necessita ser abordada sob dois aspectos: o da "comunicação inovada pela eletrônica" e o da "realidade virtual". Menezes entende que "é quase sempre impróprio falar de interação" ${ }^{41}$ na comunicação eletrônica. E na realidade virtual "o que ocorre é, antes, uma passividade gestualmente ativa" ${ }^{42}$, pois se trata de um ambiente limitado, onde "fora do previsto, não há interação, tal como num videogame" ${ }^{43}$.

Segundo ele,

\begin{abstract}
os museus estão transferindo-se para o 'imaterial' por comodismo e inércia, sem mesmo terem explorado suficientemente as dimensões de materialidade da vida humana expressa nos acervos 'tradicionais'. Sequer levaram em conta outros componentes da percepção sensorial, além do visual ${ }^{44}$.
\end{abstract}

É necessário evitar maniqueísmos. Deve-se colocar o virtual "a serviço do museu", fazendo dele um "território de exploração" onde se consideram tanto suas potencialidades quanto seus aspectos negativos ${ }^{45}$. Menezes conclui afirmando que “a idéia de um museu virtual julgo problemática em relação à especificidade que justifica o museu" ${ }^{46}$, que é, conforme citado na página anterior "operar com segmentos do universo material" ${ }^{47}$. Na seqüência dos últimos parágrafos percebese a ênfase que Menezes dá ao material sobre o imaterial no ambiente museal ${ }^{48}$.

O "partido virtual assumido pelo Museu da Língua Portuguesa" ${ }^{49}$, entretanto, é totalmente legítimo enquanto "plataforma apta a nos dar ou aprofundar a consciência (em todas as suas dimensões) do universo físico, sensorial” 50, ainda

\footnotetext{
${ }^{41}$ MENEZES, 2007, p. 62.

${ }^{42}$ Ibidem, p. 62.

43 Ibidem, p. 62.

${ }^{44}$ Ibidem, p. 65. Wagensberg fala da importância da multissensorialidade em WAGENSBERG, 2008, p. 70.

${ }^{45}$ MENEZES, 2007, p. 63-64.

46 Ibidem, p. 70.

${ }^{47}$ Ibidem, p. 61. Grifo nosso.

${ }^{48}$ No mesmo ano do texto de Menezes, 2007, o ICOM incluiu o patrimônio imaterial como matéria prima do museu.

${ }^{49}$ MENEZES, 2007, p. 65.

${ }^{50}$ Ibidem, p. 65.
} 
que com ressalvas. A real preocupação de Menezes é que esse tipo de museu se constitua em "modelo desejável do museu do futuro, destinado a substituir o museu 'tradicional'" 51.

Pelo menos com relação à importância da materialidade, o virtual num science center nos parece plenamente compatível, até porque a ênfase nos fenômenos e não nos objetos é uma das características distintivas desse tipo de museu (ver Capítulo 1).

É importante, entretanto, em qualquer que seja a visão do uso da tecnologia no ambiente museal, tomar o cuidado de não superestimá-la, até por que os melhores resultados poderiam, provavelmente, ser alcançados também pela interação com membros do staff altamente qualificados e treinados ${ }^{52}$, ou seja, mediadores.

\subsection{Interatividade}

"Segundo Piaget, a aprendizagem é fruto da interação ativa entre o aprendiz e os objetos" 53 , o que se constituiu na base teórica inicial para os experimentos interativos. Entretanto, “a interação com objetos [...] está sempre acompanhada ou até mesmo incluída em interações sociais" ${ }^{54}$.

Gaspar $^{55}$ discorre longamente sobre as teorias de Vygotsky - intrinsecamente relacionadas com as interações sociais - para fundamentar sua tese de doutorado. Vamos abordar apenas os conceitos mais pertinentes para a dissertação.

Para que possa ocorrer a aprendizagem num ambiente informal de ensino, como um museu ou centro de ciências, é necessário que "entre seus visitantes ou entre

\footnotetext{
${ }^{51}$ MENEZES, 2007, p. 65. Grifos nossos.

${ }^{52}$ WITSCHEY, 2006, Capítulo IX - Technological Downsides.

${ }^{53}$ GASPAR, 1993, Capítulo IV - Item 3.5 - Os centros de ciências e as teorias de aprendizagem. Grifo nosso.

${ }^{54}$ Ibidem, p. 152. Grifo nosso.

${ }^{55}$ Ibidem.
} 
monitores e visitantes, haja interações sociais" 56, e, além disso, que "essas interações se dirijam à zona de desenvolvimento proximal de seus participantes" ${ }^{57}$. Zona de desenvolvimento proximal - um conceito original de Vygotsky - é definida como

a distância entre o nível de desenvolvimento atual, determinado pela resolução independente de problemas, e o nível de desenvolvimento potencial, determinado através da resolução de problemas sob a orientação de adultos ou em colaboração com seus pares mais capazes $^{58}$.

Os adultos ou pares mais capazes tem função semelhante à de "mestres" para seus "aprendizes", e o tipo de interação social mais efetivo para a aprendizagem é justamente aquele no qual "os parceiros desempenham diferentes papéis sociais" 59, como nos casos de "professores e alunos, pais e filhos, adultos e jovens" ${ }^{60}$, e no qual ocorra a "verbalização de idéias, conceitos, dúvidas e inquietações" ${ }^{61}$.

A importância das interações sociais é defendida também por outros autores, como Schauble e Bartlett ${ }^{62}$, Diamond ${ }^{63}$, e Van Praet ${ }^{64}$. Perry ${ }^{65}$ relaciona a interação social como um dos seis componentes das exposições motivadoras, sendo a curiosidade, a segurança, o desafio, o controle e a diversão as outras cinco. É interessante notar que até aqui falamos sempre na eficácia das interações para o aprendizado: Perry introduz a motivação, um tema central em Wagensberg (ver Capítulo 2.1.5), que ele considera um fim em si mesmo, não necessariamente associado ao aprendizado, e muito mais importante do que ele.

\footnotetext{
${ }^{56}$ GASPAR, 1993, Capítulo V - Item 3 - Implicações da teoria de Vygotsky ao processo ensinoaprendizagem em museus e centros de ciências.

${ }^{57}$ Ibidem, Capítulo V - Item 3 - Implicações da teoria de Vygotsky ao processo ensino-aprendizagem em museus e centros de ciências. Grifo nosso.

${ }^{58}$ Ibidem, Capítulo V - Item 2.4 - O conceito de zona de desenvolvimento proximal.

${ }^{59}$ Ibidem, Capítulo V - Item 3 - Implicações da teoria de Vygotsky ao processo ensino-aprendizagem em museus e centros de ciências.

${ }^{60}$ Ibidem, Capítulo V - Item 3 - Implicações da teoria de Vygotsky ao processo ensino-aprendizagem em museus e centros de ciências.

${ }^{61}$ MARANDINO, 2008, p. 23.

${ }^{62}$ SCHAUBLE; BARTLETT, 1997, p. 786-787, 789-790.

63 DIAMOND, 1986, p. 152, apud STUDART, 2003, p. 34.

${ }^{64}$ VAN PRAET, 2005, p. 351.

${ }^{65}$ STUDART, 2003, p. 37.
} 
sob o ponto de vista sociointeracionista, não é essencial a interação com o experimento, no sentido de que o visitante o manipule, efetue montagens, verificações, etc., uma vez que não é [...] esse tipo de interação que promove a aprendizagem, sobretudo se esta manipulação for realizada individualmente $e^{66}$.

A interação fundamental seria a social, que poderia ser conseguida através de diversos meios, não apenas da manipulação.

O conjunto de dispositivos de uma exposição gera uma “idéia inicial prévia do objetivo dessa demonstração, ou seja, uma definição de situação. É fundamental que essa definição de situação seja até certo ponto esperada, previsível" ${ }^{67}$, coerente com os seus objetivos, "para que as interações sociais [...] sejam produtivas no sentido de atingir a zona de desenvolvimento proximal de seus participantes" ${ }^{68}$. Em outras palavras, deve-se obter uma "definição de situação facilmente detectável para que o monitor ou parceiro mais capaz possa conduzir a interação de forma adequada e produtiva" ${ }^{69}$. Os textos podem contribuir para essa clareza, na medida em que "os visitantes, na sua maioria, lêem os textos apresentados pelo menos até que tenham uma idéia do objetivo ou proposta da demonstração" ${ }^{70}$. Não deve haver desvios, distrações ou focos de dispersão do objetivo principal.

Pesquisas sobre a visitação de famílias em centros e museus de ciências parecem confirmar a importância das interações sociais para a própria satisfação desse público:

\footnotetext{
${ }^{66}$ GASPAR, 1993, p. 144.

${ }^{67}$ Ibidem, p. 146. Grifo nosso. Podemos fazer um paralelo entre a “definição de situação” e a importância de deixar o visitante bem informado sobre questões práticas da visita, de forma a que se sinta seguro e relaxado, podendo voltar sua atenção para a exposição em si. MARANDINO, 2008, p. 21-22;

STUDART, 2009, p. 114-115.

${ }^{68}$ GASPAR, 1993, p. 146.

69 Ibidem, p. 146.

${ }^{70}$ Ibidem, p. 148.
} 
A interação entre os membros de um grupo familiar é um aspecto importante da visita. Quando crianças se dedicam a atividades com os pais ou amigos, elas gastam mais tempo do que quando estão por sua conta, e ainda que as crianças costumem iniciar a exploração de objetos, a interação com um membro da família produz uma 'inspeção mais demorada'71.

Se a interação social e a ausência de distrações contribuem para o aprendizado, é natural que a "criação de espaços de exposição que permitam a pequenos grupos trabalhar juntos e interagir fora do fluxo geral do museu" ${ }^{72}$ seja considerada uma estratégia positiva. “[...] um aparato interativo que só possa ser usado por uma única pessoa não encoraja interações sociais" 73. Os diversos elementos que compõe as exposições devem ser pensados de forma a facilitar essas interações, incluindo os textos e ilustrações ${ }^{74}$, a disposição dos objetos no espaço, os percursos possíveis para o visitante ${ }^{75}$.

\begin{abstract}
Quando a arquitetura e a ambientação de um centro de ciências culminam em um conjunto integrado por elementos que formam um todo belo, congruente e funcional, resulta não apenas um espaço estimulante para aprender; também para estar e para conviver com os outros ${ }^{76}$.
\end{abstract}

Por outro lado, Studart descreve uma pesquisa de Blud ${ }^{77}$ com cinqüenta grupos familiares em três exposições diferentes - uma completamente interativa, uma do tipo "aperta-botão" e uma estática, na qual não houve diferença significativa de aprendizado de conteúdos específicos entre os freqüentadores de cada uma das três exposições, ainda que as interativas tenham provocado mais discussões entre os participantes. Studart apresenta também pesquisa de Hilke ${ }^{78}$, onde se verificou que " $72 \%$ de todos os comportamentos que funcionavam na aquisição de

\footnotetext{
${ }^{71}$ WHITE, 1990, p. 8. Afirmação semelhante se faz em DIERKING, 2009, p. 78,

${ }^{72}$ DIERKING, 2009, p. 82.

73 STUDART, 2003, p. 35.

${ }^{74}$ GASPAR, 1993, p. 148.

${ }^{75}$ CURY, 2006, p. 47.

${ }^{76}$ PADILLA, 2001. p. 123.

77 STUDART, 2003, p. 35.

${ }^{78}$ Ibidem, p. 36.
} 
informações relacionavam-se com estratégias pessoais [e não com as estratégias cooperativas]".

Existe uma categorização de interatividade, baseada em Wagensberg ${ }^{79}$, mais ou menos consagrada. Segundo ela, à interatividade hands-on corresponde o toque e manipulação física; ao minds-on corresponde o engajamento intelectual; e a interatividade heart-on se relaciona com a emoção e a cultura ${ }^{80}$. A forma embrionária, entretanto, foi a de "apertar o botão", ou "push-button", que é um tipo de interatividade manipulativa ${ }^{81}$ de simples toque ${ }^{82}$. A essas categorias, Pavão e Leitão ${ }^{83}$ sugerem acrescentar a interatividade social-on, termo criado por analogia com os outros três, que implica na interação social, na conversação ${ }^{84}$ entre os diversos participantes das atividades desenvolvidas.

Uma possibilidade negativa em exposições supostamente interativas, particularmente nas do tipo "push-button", é que o apertar do botão se dê como "compulsão psicomotora", sem que o visitante ao menos espere a conclusão do efeito produzido nem se permita alargar sua percepção e cognição ${ }^{85}$. Nesse tipo de experimento, a resposta é única, e "não é possível fazê-lo funcionar diferentemente a fim de se testar uma hipótese" ${ }^{86}$.

Entretanto, Gaspar cita estudos de Eason e Linn nos quais não foi verificada diferença significativa no grau de aprendizado a partir dos processos "push-button" e "hands-on" (manipulação direta) ${ }^{87}$.

\footnotetext{
${ }^{79}$ WAGENSBERG, 2005a, p. 4 e 2003, p. 16.

${ }^{80}$ Ibidem, p. 4 e 2003, p. 16; MARANDINO, 2008, p. 22; CHELINI; LOPES, 2008, p. 231.

${ }^{81}$ PADILLA, 2001, p. 123.

82 CHELINI; LOPES, 2008, p. 232.

${ }^{83}$ PAVÃO; LEITÃO, 2007, p. 40.

${ }^{84}$ WAGENSBERG, 2008, p. 69.

${ }^{85}$ MENEZES, 2006, p. 63.

${ }^{86}$ FALCÃO, 2007, p. 126.

${ }^{87}$ GASPAR, 1993, p. 145.
} 
Segundo Pavão e Leitão, “A influência da proposta hands-on nos museus 'tradicionais' tem sido visível. Eles têm se reformulado, a partir de abordagens inovadoras, e em geral incorporado a interatividade" ${ }^{88}$.

“Às vezes os termos interativo e hands-on (manipulação) se usam indistintamente; entretanto, não são a mesma coisa" ${ }^{89}$. "As exibições manipuláveis (hands-on) implicam simplesmente na ação física do usuário sobre a exibição [...]" 90 . O termo hands-on, entretanto, se difundiu e é até mesmo utilizado para denominar os museus de ciências interativos ${ }^{91}$.

Associados à interatividade hands-on estão os módulos ou modelos interativos ${ }^{92}$. Eles são "construções tridimensionais projetadas para que o visitante possa manipulá-las de algum modo, ou explorar o que se possa fazer fisicamente, com o objetivo de compartilhar algum entendimento com o [seu] projetista desconhecido [...]" 93. Eles "podem ser projetados para uso individual ou em grupo" 94.

Muitas vezes esses modelos são reproduções de instrumentos científicos originais, que os representam a partir de características específicas escolhidas criteriosamente em consonância com os objetivos pretendidos ${ }^{95}$. São diferentes de réplicas, que tentam ser cópias fiéis do original. Por motivos de preservação, os originais normalmente não podem ser manipulados. Os modelos didáticos, por outro lado, visam exatamente à manipulação e à interatividade ${ }^{96}$, propiciando que “o público visitante explore o funcionamento e os conceitos relativos aos instrumentos $[\ldots]]^{97}$, e que possa compreender um princípio ou um fenômeno ${ }^{98}$.

\footnotetext{
${ }^{88}$ PAVÃO; LEITÃO, 2007, p. 40.

${ }^{89}$ PADILLA, 2001, p. 123.

${ }^{90}$ Ibidem, p. 123.

${ }^{91}$ PAVÃO; LEITÃO, 2007, p. 40.

${ }^{92}$ McManus utiliza o termo módulo, mas a expressão modelo interativo, utilizado pela maioria dos autores, nos parece mais adequado.

${ }^{93}$ MCMANUS, 2009, p. 60.

${ }^{94}$ Ibidem, p. 61.

${ }^{95}$ FALCÃO, 2007, p. 129; CURY, 2000, p. 2.

${ }^{96}$ FALCÃO, 2007, p. 126; CURY, 2000, p. 2.

${ }^{97}$ FALCÃO, 2007, p. 129.

${ }^{98}$ MCMANUS, 2009, p. 60; CURY, 2000, p. 3.
} 
Um outro tipo de atividade que pode ser utilizada num centro de ciências são os jogos interativos. Na Nanoaventura, do Museu de Ciências da UNICAMP, foram desenvolvidos jogos eletrônicos interativos para até 12 pessoas, "uma proposta educativa fortemente lúdica" ${ }^{99}$ e que visa favorecer as interações sociais.

“[...] a interatividade do tipo hands-on não necessariamente conduz a experiências significativas, pois apesar de realizar a ação que se espera, o visitante pode não construir um sentido daquilo que acontece a posteriori" ${ }^{100}$. Outro aspecto potencialmente negativo é a padronização de experimentos com final fechado baseados na utilização inadequada da interatividade hands-on, os quais não propiciam a reflexão ${ }^{101}$.

Oppenheimer, do Exploratorium de São Francisco, entende que o hands-on, "sempre deveria estar ligado ao conceito minds-on" ${ }^{102}$, ou seja, a manipulação deveria objetivar o envolvimento intelectual. E Wagensberg afirma que "Tem que haver também uma interatividade mental, mais importante que a manual" ${ }^{103}$.

A interatividade minds-on implica no engajamento intelectual, numa postura crítica, que deve possibilitar a "compreensão científica: distinguir o essencial do acessório, ver o que há de comum entre o que é aparentemente distinto, estabelecer relações entre o que se vê no museu e no cotidiano" ${ }^{104}$. E se há o engajamento intelectual, é possível incluir atividades e/ou exposições que lidem com questões controversas $^{105}$ (ver Capítulo 2, tópico 2.1.3).

Segundo Falcão, o desejado engajamento intelectual não está necessariamente associado a estratégias interativas, e pode mesmo ser conseguido com exposições contemplativas, visto que ele é decorrente de variados fatores, "como o ambiente,

\footnotetext{
${ }^{99}$ KNOBEL; MURRIELLO, 2008, p. 80.

${ }^{100}$ FALCÃO, 2007, p. 126-127. Ver também GUISASOLA; MORENTIN; ZUZA, 2005, p. 544-545.

${ }^{101}$ PAVÃO; LEITÃO, 2007, p. 41.

102 Ibidem, p. 40.

${ }^{103}$ WAGENSBERG, 2003, p. 16.

${ }^{104}$ CHELINI; LOPES, 2008, p. 232

${ }^{105}$ Ibidem, p. 232
} 
a forma de apresentação, as características físicas do exhibit, a complexidade do tema e o paradigma educacional adotado na exposição" ${ }^{106}$. Danilov afirma que, embora aparatos interativos sejam comumente utilizados, a participação emocional ou intelectual pode ser conseguida sem esses recursos ${ }^{107}$.

A terceira categoria de interatividade é a heart-on. "A palavra [chave] 'museística' é a emoção. [...] Um bom museu está baseado em emoções [...]" ${ }^{108}$. Essa é a ênfase geralmente dada por Wagensberg. Chelini e Lopes, entretanto, destacam o aspecto cultural do heart-on:

embora a ciência seja universal, a realidade na qual ela se desenvolve não o é. Assim, para promover a interatividade cultural, uma exposição deve tentar priorizar as identidades presentes no entorno do museu, promovendo a identificação, com o acervo, do visitante da comunidade local; e um despertar para uma nova cultura, quando o visitante é de outras localidades ${ }^{109}$.

Afirmam ainda que a exposição pode "criar um impacto emocional que estimula o interesse do visitante e favorece a memorização" ${ }^{110}$, o que poderia estar associado à interatividade heart-on.

Para que as pessoas se interessem pela ciência, Wagensberg defende a importância da utilização de objetos reais, e que sejam, preferencialmente, interativos nas três categorias: hands-on, minds-on e heart-on ${ }^{111}$. "Nem sempre, no entanto, os três níveis de interatividade [...] podem ser encontrados juntos em uma mesma exposição" ${ }^{112}$.

\footnotetext{
${ }^{106}$ FALCÃO, 2007, p. 127.

${ }^{107}$ DANILOV, 1982, p. 5.

${ }^{108}$ WAGENSBERG, 2003, p. 16.

${ }^{109}$ CHELINI; LOPES, 2008, p. 232.

${ }^{110}$ Ibidem, p. 233.

${ }^{111}$ WAGENSBERG, 2005a, p. 4.

${ }^{112}$ CHELINI; LOPES, 2008, p. 233.
} 
Alguns autores defendem que as exposições realmente interativas são aquelas que permitem múltiplas ações e reações entre o equipamento e o visitante ${ }^{113}$. Padilla indicava, em texto de 2001, como tendência para o ano de 2015 os experimentos de final aberto, que oferecessem "múltiplas variantes - às vezes inclusive de uma maneira não prevista pelos projetistas" ${ }^{114}$, e que "não supõe uma só resposta ‘correta' ou um resultado final predeterminado" ${ }^{115}$, o que é coerente com as preocupações de Menezes, como citado no tópico 3.1.

Conforme visto no decorrer do capítulo, apesar de haverem pesquisas que indiquem indiferença, a maioria dos autores entende que a interatividade, particularmente a social e com envolvimento intelectual, é mais indicada para o aprendizado e a motivação.

\subsection{Mediação}

Segundo Pavão e Leitão, o monitor - mediador humano - “é o elemento interativo por excelência e natureza" ${ }^{116}$. "Por sua intervenção competente, os visitantes são estimulados a interagirem uns com os outros (social-on) e com o objeto do conhecimento (hands-on/minds-on/hearts-on)" ${ }^{117}$, sem necessariamente oferecer respostas, mas fomentando "a crítica, a curiosidade e a indagação" ${ }^{118}$.

Existem também suportes físicos que compõe a mediação entre a instituição e o visitante: "a sinalização, o layout das galerias, os instrumentos, e os textos que transmitem significados" 119 , além do próprio projeto museológico ${ }^{120}$. Segundo

\footnotetext{
${ }^{113}$ PADILLA, 2001, p. 123; FALCÃO, 2007, p. 126.

${ }^{114}$ PADILLA, 2001, p. 136. Tradução nossa.

115 Ibidem, p. 136. Tradução nossa.

${ }^{116}$ PAVÃO; LEITÃO, 2007, p. 41 e 45.

117 Ibidem, p. 41.

118 Ibidem, p. 41.

${ }^{119}$ SCHAUBLE; BARTLETT, 1997, p. 790. Tradução nossa.

${ }^{120}$ VAN PRAET, 2005, p. 352.
} 
Schauble e Bartlett ${ }^{121}$ a mediação - instrumental ou humana - é fundamental nos museus.

Marandino entende que, embora não seja a única, “a mediação humana é a melhor forma de garantir que a mensagem proposta pelos idealizadores [da exposição] seja compreendida" ${ }^{122}$. Ela vê no mediador "a 'voz' da instituição, o elemento de ligação entre o museu e o público" ${ }^{123}$. Para Gaspar, "o monitor deve exercer sempre que possível o papel de parceiro mais capaz numa interação social; caso essa interação não ocorra espontaneamente, ele deve tentar provocá-la" ${ }^{124}$. Segundo Wagensberg, “Bons guias são estudantes universitários, entre 18 e 25 anos [e que] [...] não devem permanecer na função por mais de quatro anos, para não se acomodarem [...]" ${ }^{125}$.

Uma das estratégias onde a participação de um mediador humano habilidoso é indispensável é a "demonstração ao vivo" ("live demonstrations"), na qual princípios científicos e aplicações tecnológicas são apresentados nas próprias áreas de exposições ou em auditórios ou teatros ${ }^{126}$. O Palais de la Découverte, em Paris, tem um dos mais completos programas de demonstrações ao vivo de centros de ciências ${ }^{127}$.

Uma outra forma de mediação ocorre não entre a instituição e o visitante, mas entre o cientista e o público, e seu agente é o divulgador mediador, que pode ser jornalista, especialista de mídias, integrante da equipe dos museus ou docente de ciências ${ }^{128}$ (ver Capítulo 2, tópico 2.1.2).

\footnotetext{
${ }^{121}$ SCHAUBLE; BARTLETT, 1997, p. 791.

${ }^{122}$ MARANDINO, 2008, p. 12. Grifo nosso.

${ }^{123}$ Ibidem, p. 12.

${ }^{124}$ GASPAR, 1993, p. 150

${ }^{125}$ WAGENSBERG, 2008, p. 69.

${ }^{126}$ GASPAR, 1993, p. 208 e 249.

${ }^{127}$ Ibidem, p. 249.

${ }^{128}$ JACOBI, 2005, p. 362.
} 
As novas abordagens museológicas com foco no público (ver Capítulo 2, tópico 2.1.2) levaram as exposições a serem preparadas "sob a óptica do público" ${ }^{129}$, levando em conta "o conhecimento prévio do visitante" ${ }^{130}$, tanto na sua concepção quanto na sua apresentação pelo mediador. Para isso, ele precisa "obter informações sobre o visitante, buscando estabelecer pontes entre os conhecimentos que trazem - conceitos, vivências, idéias - e aqueles apresentados nesses locais" 131, com o objetivo de alcançar interações humanas de qualidade ${ }^{132}$.

Apesar da importância da mediação humana retratada acima, Danilov, em seu livro de 1982, afirmava que as visitas monitoradas estavam diminuindo em número em razão "dos custos de pessoal e da dificuldade em manter grupos coesos em ambientes participativos" ${ }^{133}$. Esse tipo de monitoramento foi opcionalmente sendo substituído por mediadores fixos em diversos pontos do museu, além de uma maior participação dos próprios professores das escolas visitantes.

Uma outra estratégia para minimizar a mediação humana parece ser através da utilização dos novos recursos tecnológicos citados anteriormente neste capítulo (no tópico 3.1) como novas formas de mediação, buscando possibilitar que o público se torne "better self-directed learners" ${ }^{134}$.

Dá-se o exemplo do programa Pathways to Learning, do University of Arizona Science Center, em Tucson, no qual são utilizados transponders ${ }^{135}$ para monitorar o percurso e as atividades desenvolvidas pelo visitante, de forma a que se possa guiá-lo eletronicamente no espaço físico do museu e em seu website ${ }^{136}$. Ela tende a

\footnotetext{
${ }^{129}$ CURY, 2006, p. 38.

${ }^{130}$ FALCÃO, 2007, p. 127.

131 MARANDINO, 2008, p. 20.

132 Ibidem, p. 22.

133 DANILOV, 1982, p. 249. Tradução nossa.

${ }^{134}$ WITSCHEY, 2006, p. 11. A expressão poderia ser traduzida como: “que consegue melhorar sua capacidade de auto-aprendizado”.

${ }^{135}$ Transponder é um "aparelho emissor-receptor que responde automaticamente a uma mensagem de identificação, ao sinal de um radar”. HOUAISS, 2001b. Verbete transponder.

${ }^{136}$ WITSCHEY, 2006, p. 11.
} 
eliminar ou minimizar a interação humana, e, nesse sentido está em desacordo com os referenciais teóricos expostos no tópico 3.2 do presente capítulo.

Coloca-se então uma questão: pode esse tipo de tecnologia aplicada em museus fomentar as interações humanas entre os visitantes? 


\section{MUSEOLOGIA E EXPOSIÇÕES}

\subsection{Conceitos fundamentais da museologia}

O objetivo desse item é apresentar os conceitos fundamentais relacionados com as exposições, de forma a poder utilizá-los com clareza no restante da dissertação.

A definição de museologia sofreu alterações no tempo. Segundo Chagas, Gustavo Barroso a teria definido em 1945 como "o estudo científico de tudo o que se refere aos museus" ${ }^{1}$. Passadas algumas décadas, uma das abordagens de Mensch sobre a museologia a coloca "como o estudo da relação específica do homem com a realidade" ${ }^{2}$. Essa abordagem prevaleceu na definição internacional de museologia e impôs-se aos museólogos brasileiros. Assim, na década de 1990 Waldisa Russio Camargo Guarnieri definiu museologia como "a relação profunda entre o Homem, sujeito que conhece, e o Objeto, parte da Realidade à qual o Homem também pertence e sobre a qual tem o poder de agir" ${ }^{3}$. Segundo Cury, esta relação se dá no museu, um "cenário institucionalizado"4.

Refletindo essa evolução, torna-se necessário fazer a distinção entre os termos museal e museológico. Nas palavras de Chagas: "Considero museal como aquilo que se refere ao museu e o museológico como aquilo que se refere à museologia" 5 .

A expologia é uma parte da museologia, que "estuda a teoria da exposição [...] e envolve os princípios museológicos, comunicacionais e educacionais de uma exposição $[\ldots] "{ }^{6}$. Alguns paradigmas foram sendo superados ao longo dos últimos séculos, como as “coleções exaustivas, a exposição por categorias tipológicas, a

\footnotetext{
${ }^{1}$ CHAGAS, 2001, p. 55.

${ }^{2}$ CURY, 2006, p. 29.

${ }^{3}$ Ibidem, p. 30.

${ }^{4}$ Ibidem, p. 30.

${ }^{5}$ CHAGAS, 2001, p. 48 (nota de rodapé 1).

${ }^{6}$ CURY, 2006, p. 27.
} 
perspectiva do domínio sobre a verdade e a interatividade como eixo norteador das exposições" ${ }^{7}$. Com relação ao último item, fica claro que a interatividade em si não garante uma boa exposição - ela não pode ser considerada como um fim em si mesmo.

A museografia "engloba todas as ações práticas de um museu: planejamento, arquitetura e acessibilidade, documentação, conservação, exposição e educação" 8 .

A expografia é uma parte da museografia que "visa à pesquisa de uma linguagem e de uma expressão fiel na tradução de programas científicos de uma exposição" 9 e que deve estar de acordo com os princípios expológicos ${ }^{10}$. Ela é a "museografia da exposição [...] e consiste em um conjunto de ações no sentido da sua concretização" ${ }^{11}$, envolve o design de exposições, os elementos de identidade visual, textos, legendas, ilustrações, fotografias, cenários, mobiliário, sons, texturas, cheiros, temperatura, etc. ${ }^{12}$

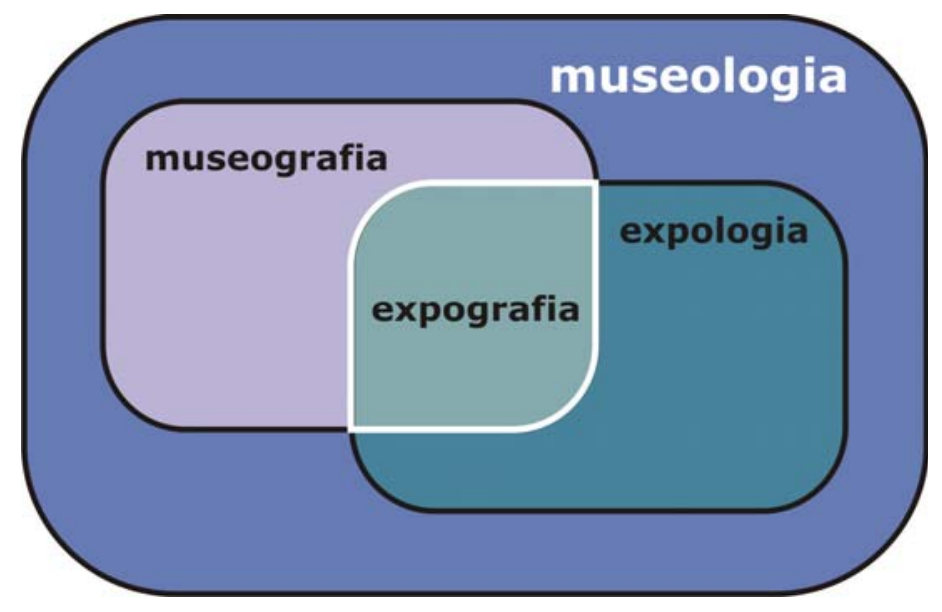

Fig. 01 - Esquema relacionando museologia, museografia, expologia e expografia. Original do autor, 2011.

A museografia está para a museologia assim como a expografia está para a expologia. A museologia engloba a museografia e a expologia; a expografia se subordina tanto à museografia quanto à expologia.

\footnotetext{
${ }^{7}$ BRUNO, 2001, p. 268.

${ }^{8}$ CURY, 2006, p. 27.

${ }^{9}$ Ibidem, p. 27. Grifo nosso.

${ }^{10}$ Ibidem, p. 27.

${ }^{11}$ Ibidem, p. 113. Ver também CHELINI; LOPES, 2008, p. 207.

${ }^{12}$ CURY, 2006, p. 13 e 46.
} 
A musealização visa atender ao próprio critério da museologia, de "provocar o confronto do Homem com sua Realidade" ${ }^{13}$. É um processo seletivo de valorização dos objetos, que consiste nas ações de "aquisição, pesquisa, conservação, documentação e comunicação" ${ }^{14}$. "Esta valorização poderá ocorrer com a transferência do objeto de seu contexto para o contexto dos museus ou, ainda, a sua valorização in situ, como ocorre nos ecomuseus" ${ }^{15}$.

Em qualquer dos casos se dá, segundo Pomian, "sua retirada da esfera econômica e a liberação de seus usos anteriores" ${ }^{16}$. Por outro lado, Chagas afirma que há "a atribuição de novas funções e novos significados para esses objetos, sem que haja obrigatoriamente perda dos significados e funções anteriores" ${ }^{17}$, o que flexibiliza a questão do uso de Pomian.

Cecília Lourenço associa a coleção (privada) a termos como lazer, capricho, amuleto, vaidade, indivíduo, gosto pessoal, enquanto o acervo “Pressupõe o debate e a eleição de critérios, o estabelecimento de plano de metas, dentro de padrões especialmente formulados segundo a realidade existente" ${ }^{18}$. Ela enfatiza essa diferenciação movida pela "idéia de [que o] museu público gerado a partir de coleções privadas" 19 trazia consigo embutido um problema: o de que essas coleções vinham imbuídas dos desejos também privados e individuais de quem as formou. Segundo Cury, a superação desse problema "ocorre quando os objetos de

\footnotetext{
${ }^{13}$ CURY, 2006, p. 30.

${ }^{14}$ Ibidem, p. 26.

${ }^{15}$ Ibidem, p. 24. Em DAVALLON, 2005, p. 358, as entrevistadoras Luciana Sepúlveda Koptcke e Luisa Massarani discorrem sobre os ecomuseus: "O Movimento de Ecomuseu foi desenvolvido da década de 1970, inicialmente na França, por Georges Henri Rivières e Hugues de Varines. Os ecomuseus se fundamentam na idéia de territorialidade, considerando que a construção identitária a partir de uma comunidade ou território parte do reconhecimento ativo, pelos grupos envolvidos, de seu passado, sem a exclusão dos conflitos existentes, gerando uma atitude de apropriação ativa, reflexiva e incorporando as tradições, as mudanças e a reflexividade como contribuição para decidir o futuro."

${ }^{16}$ PANESE, 2007, p. 33. Ver também FALCÃO, 2007, p. 125.

${ }^{17}$ CHAGAS, 2007, p. 29. Grifo nosso.

${ }^{18}$ CURY, 2006, p. 35-36.

${ }^{19}$ Ibidem, p. 35.
} 
uma coleção, e portanto inseridos em um determinado universo de relações, interagem com outros de forma a alterar as intenções de seu formador inicial" 20 .

A maioria dos autores, entretanto, enfoca outros aspectos da coleção. Pomian, por exemplo, a descreve como

qualquer conjunto de objetos naturais ou artificiais, mantidos temporária ou definitivamente fora do circuito das atividades econômicas, sujeitos a uma proteção especial num local fechado preparado para esse fim, e expostos ao olhar do público. [...] essas condições são satisfeitas não só pelos museus e pelas coleções particulares, mas também pela maior parte das bibliotecas e dos $\operatorname{arquivos}^{21}$

De qualquer forma, os acervos e coleções são utilizados para se atingir os objetivos gerais da instituição museu, e os objetivos específicos de cada museu em particular. Para alcançar esses objetivos é necessário fazer escolhas, e ter uma política clara de forma a otimizar o uso dos espaços e recursos disponíveis ${ }^{22}$.

A teoria museológica de Moebius ${ }^{23}$ determina que a coleção científica deva ser tão completa quanto possível pois objetiva a investigação, a pesquisa. Já a parcela disponibilizada à fruição do público, baseada na totalidade da coleção, deve ser criteriosamente organizada e apresentada apenas com os exemplares mais representativos de acordo com a abordagem desejada ${ }^{24}$.

Conforme visto no Capítulo 1, normalmente os centros e museus de ciências não possuem objetos históricos originais, ou não se fundamentam nesse tipo de objetos $^{25}$. Portanto, enquanto os museus tradicionais - e os museus de história natural - realizam pesquisas sobre os objetos de suas coleções, os centros de ciência e tecnologia costumam pesquisar temas como "preparação de exposições,

\footnotetext{
${ }^{20}$ CURY, 2006, p. 35.

${ }^{21}$ POMIAN, 1997, p. 53.

${ }^{22}$ DANILOV, 1982, p. 183 e 191.

${ }^{23}$ GIL, 1988, p. 75. Essa teoria foi implementada em 1891 no museu de história natural de Berlim.

${ }^{24}$ Ibidem, p. 75-76.

${ }^{25}$ DANILOV, 1982, p. 4, 60 e 181.
} 
avaliação de exposições e programas, perfil de visitação, e programas educacionais" ${ }^{26}$, e baseiam suas atividades em modelos (ver Capítulo 3, tópico 3.2), que, no caso dessas instituições "são os correspondentes materiais das coleções museológicas" ${ }^{27}$. Isso não constitui nenhuma aberração, visto que Rivière afirma que "a comunicação em museus pode se dar por originais de coleções ou por modelos" 28 .

O uso de modelos também se expandiu, pela liberdade que permite à equipe dos museus de eleger um tema para uma exposição - pois pode partir de uma idéia e essa idéia não precisa estar conectada à coleção museológica - e por permitir uma grande flexibilidade às experimentações educacionais $[\ldots] .{ }^{29}$

Chelini e Lopes fazem a importante observação de que "embora os modelos guardem uma relação com a realidade, eles não são a realidade" ${ }^{30}$, e isso deveria estar sempre explícito nas exposições.

O termo salvaguarda está associado à “documentação e [à] conservação de coleções museológicas" ${ }^{31}$, enquanto a comunicação se relaciona com "ações públicas em geral, especialmente exposições e estratégias educativas" ${ }^{32}$. Assim, é natural que os centros de ciência, sem coleções museológicas de valor intrínseco, concentrem suas ações no aspecto comunicacional.

A comunicação museológica inclui, além das exposições, "artigos científicos [...], catálogos, material didático [...], vídeos e filmes, palestras, oficinas e material de divulgação e/ou difusão diversos" 33 .

A concepção museológica pressupõe as discussões expológica, conceitual e temática. Inclui a concepção espacial (planta conceitual, planta arquitetônica e

\footnotetext{
${ }^{26}$ DANILOV, 1982, p. 191-192.

${ }^{27}$ CURY, 2000, p. 3.

${ }^{28}$ Ibidem, p. 3.

${ }^{29}$ Ibidem, p. 3. Ver também DANILOV, 1982, p. 212.

${ }^{30}$ CHELINI; LOPES, 2008, p. 226.

${ }^{31}$ CURY, 2000, p. 5.

32 Ibidem, p. 5. Ver também BRUNO, 2001, p. 268.

${ }^{33}$ CURY, 2006, p. 34.
} 
circuito) e a concepção formal (padrão de composição visual, visualidade tridimensional da exposição e padrão expográfico) ${ }^{34}$. Na concepção museológica podem estar envolvidos diversos profissionais, como pesquisadores das áreas básicas, historiadores, educadores, museólogos, documentalistas, artistas plásticos e $\operatorname{arquitetos}^{35}$.

A concepção expográfica implica nas discussões espacial e formal e na concretização da exposição ${ }^{36}$. Estabelece "as bases para o design da exposição, ou seja, as bases para a composição visual do todo e das partes, em um espaço físico" 37, e inclui a concepção das vitrinas, do mobiliário, dos sistemas de iluminação e outros recursos sensoriais, dos sistemas de segurança e do controle ambiental ${ }^{38}$. A concepção expográfica pode ser vista como um projeto de arquitetura de interiores embasado na museologia e na expologia, e, como tal, deve ser o resultado da parceria entre o museólogo e o arquiteto. “É ele [o arquiteto] que materializa os valores embutidos no enunciado central e no seu desenvolvimento conceitual. É ele também que dá valor ao espaço e torna a experiência do público possível, a experiência sensorial, interativa e criativa" 39.

O museólogo e o arquiteto, entretanto, não são os únicos profissionais envolvidos: fazem parte de uma equipe de concepção expográfica, além daqueles que elaboram a concepção museológica, o programador visual, o light designer, o cenógrafo, o cenotécnico e o aderecista ${ }^{40}$.

\footnotetext{
${ }^{34}$ CURY, 2006, p. 102-104.

35 Ibidem, p. 108.

${ }^{36}$ Ibidem, p. 102.

${ }^{37}$ Ibidem, p. 104-105.

${ }^{38}$ Ibidem, p. 104-105.

${ }^{39}$ Ibidem, p. 113.

${ }^{40}$ Ibidem, p. 108.
} 


\subsection{Recursos expográficos}

Chelini e Lopes definem exposição como "um meio de comunicação que permite ao público aprender e vivenciar experiências não somente intelectuais, mas também emocionais" 41. Ela deve usar estratégias de comunicação "simples e acessíveis" ${ }^{42}$, contribuindo para a divulgação científica. Cury afirma que o "elemento estruturador da exposição é o objeto museológico" ${ }^{43}$ e a subdivide didaticamente em conteúdo e forma. Ao conteúdo corresponde a informação científica e o entendimento da comunicação como interação. A forma é constituída pelas estratégias que vão dar à exposição suas qualidades sensoriais: organização, enfoque temático, seleção dos objetos, concepção espacial e visual, entre outros ${ }^{44}$.

Ainda que o conteúdo possa ser considerado mais importante do que o desenho da exposição, este é crucial para atrair o visitante, comunicar o conteúdo ${ }^{45}$, além de influenciar na experiência geral do público ${ }^{46}$. Forma e conteúdo devem estar em sincronia, reforçando uma ao outro, para o sucesso da exposição ${ }^{47}$. Segundo texto de Danilov de 1982, o desenho das exposições recebia muito mais cuidado nos centros de ciência e tecnologia do que em outros tipos de museus ${ }^{48}$.

As exposições museológicas "constituem-se na interface entre a instituição e o público" ${ }^{49}$. O processo de concretização da exposição é uma experiência da equipe do museu, e pode ser visto como seu produto final. Entretanto, o processo só é concluído com a experiência do visitante, sua fruição da exposição ${ }^{50}$. Essa experiência inclui:

\footnotetext{
${ }^{41}$ CHELINI; LOPES, 2008, p. 207.

${ }^{42}$ Ibidem, p. 208.

${ }^{43}$ CURY, 2006, p. 46.

${ }^{44}$ Ibidem, p. 42.

${ }^{45}$ DANILOV, 1982, p. 200.

${ }^{46}$ CURY, 2006, p. 47.

${ }^{47}$ DANILOV, 1982, p. 193.

${ }^{48}$ Ibidem, p. 200.

${ }^{49}$ CURY, 2006, p. 115.

${ }^{50}$ Ibidem, p. 45.
} 
Estar na exposição, caminhar por seu espaço, observar os objetos, aprender o seu conteúdo temático, apreciar os efeitos expográficos e sensoriais, observar, analisar, julgar, criticar, comparar, relacionar, lembrar, rejeitar, concordar, discordar, emocionar-se ${ }^{51}$.

Cor, luz e movimento são fatores que influenciam bastante a experiência do visitante $^{52}$. O uso da luz, em particular, deve ser cuidadoso para evitar danos a documentos em papel, melhorar o desempenho energético do ambiente e favorecer a legibilidade das informações ${ }^{53}$.

Os percursos possíveis do público são definidos a partir do conceito da exposição "frente ao que se acredita ser a melhor forma de interação entre a proposta do museu e seu público por meio do espaço" ${ }^{54}$ :

[...] uma exposição pode ter uma organização espacial linear (seqüencial, passo a passo e com começo, meio e fim), quando a compreensão de um momento depende do anterior, ou episódica, quando o público faz suas escolhas e constrói criativamente seu caminho [...] ${ }^{55}$.

É recorrente nos textos dos museólogos e educadores de museus que valorizam as interações sociais a indicação de tornar possível a participação de diversas pessoas em colaboração num mesmo experimento ao mesmo tempo. Um dos aspectos dessa estratégia seria tornar a área ao redor de um experimento ampla o suficiente para acomodar diversas pessoas ${ }^{56}$.

No que se referem à sua continuidade no tempo e no espaço as exposições podem ser classificadas em permanentes, temporárias e itinerantes.

\footnotetext{
${ }^{51}$ CURY, 2006, p. 44.

${ }^{52}$ DANILOV, 1982, p. 204-205.

${ }^{53}$ Ibidem, p. 204. Ver também CANAS, 2004, p. 16.

${ }^{54}$ CURY, 2006, p. 47.

${ }^{55}$ Ibidem, p. 47. Grifo nosso. Ver também MARANDINO, 2008, p. 20.

${ }^{56}$ BLACK, 1990, p. 24; DIERKING, 2009, p. 83; STUDART, 2003, p. 37-38.
} 
Para ser considerada permanente uma exposição deve durar pelo menos dois ou três anos ${ }^{57}$, podendo esse período ser na verdade muito maior.

Surgidas nos anos $1970^{58}$, as exposições temporárias e itinerantes apresentam essencialmente uma única diferença. Quando se diz que uma exposição é temporária, não há nenhum compromisso com sua instalação em mais do que um local ou instituição, o que, por outro lado, está implícito no próprio termo itinerante. Ambas são idealizadas para serem apresentadas por um período limitado, normalmente na faixa de semanas ou meses, têm foco em temas mais específicos, são - geralmente - menores e mais baratas do que as exposições permanentes ${ }^{59}$, utilizando inclusive materiais menos duráveis ${ }^{60}$.

O fato de uma exposição não ser permanente permite o "uso de técnicas [museográficas / expográficas] mais teatrais, para passar sua mensagem mais rapidamente, já que provavelmente será vista uma única vez pelo público" ${ }^{61}$ e não compromete a instituição com sua linha de concepção específica ${ }^{62}$. Por outro lado, elas estimulam o retorno de visitantes que já conhecem a instituição ${ }^{63}$.

Como a exposição itinerante será constantemente desmontada, transportada e remontada, em sua confecção devem ser utilizados materiais leves, de fácil portabilidade ${ }^{64}$. Alguns centros de ciência e tecnologia desenvolvem exposições itinerantes para seu próprio uso e o de outras instituições, além de absorver exposições produzidas fora. Outros centros de ciência, com menor quantidade de recursos, se constituem apenas em beneficiários das exposições produzidas pelos outros $^{65}$.

\footnotetext{
${ }^{57}$ DANILOV, 1982, p. 199.

58 JACOMY, 2007, p. 22.

${ }^{59}$ DANILOV, 1982, p. 225.

${ }^{60}$ Ibidem, p. 228.

${ }^{61}$ CHELINI; LOPES, 2008, p. 211. Ver também DANILOV, 1982, p. 228.

${ }^{62}$ DANILOV, 1982, p. 228.

${ }^{63}$ Ibidem, p. 225.

${ }^{64}$ Ibidem, p. 228.

${ }^{65}$ Ibidem, p. 228.
} 
Um tipo específico de exposição itinerante é a do tipo furgão ou caminhonete que vai apresentar exibições do museu fora de sua sede. O veículo pode se constituir ele mesmo em sala de exposição onde o público adentra e faz sua visita, ou servir apenas como transporte para dispositivos móveis que vão ser apresentados em área preparada para tal ${ }^{66}$.

Rivière, em seu "La museologie selon Georges Henri Rivière", comenta sobre o surgimento de diversos recursos expográficos e decisões museológicas ao longo do tempo: as vitrinas, a substituição das coleções exaustivas de objetos repetidos (panóplias) pela apresentação de exemplares selecionados, os dioramas, e a interatividade ${ }^{67}$.

O diorama é uma representação expográfica de uma cena ou ambiente com a inclusão de personagens para compor a ambientação e facilitar a compreensão de um momento da história humana ou natural ${ }^{68}$. I nicialmente eles eram compostos apenas por imagens, mas passaram a receber objetos "a fim de aumentar a sensação de realismo" ${ }^{69}$. Segundo Miles, o diorama tem a vantagem de "permitir a apresentação de objetos tridimensionais em um dado contexto, combinados em eventos que não ocorreriam simultaneamente no mundo real" 70 .

Pesquisa de Asensio e Pol no Milwaukee Public Museum indica que os dioramas, em especial os de maior tamanho, são equipamentos com grande poder de atração e retenção da atenção dos visitantes, proporcionando “maiores níveis de interação e envolvimento intelectual" ${ }^{71}$, e que, segundo Jacomy, "fornecem um tipo de informação que nenhuma outra mídia pode substituir" 72 .

\footnotetext{
${ }^{66}$ DANILOV, 1982, p. 236.

${ }^{67}$ CHELINI; LOPES, 2008, p. 209.

${ }^{68}$ JACOMY, 2007, p. 19.

${ }^{69}$ CHELINI; LOPES, 2008, p. 226.

${ }^{70}$ Ibidem, p. 226. Grifo nosso.

${ }^{71}$ Ibidem, p. 226.

72 JACOMY, 2007, p. 19.
} 
Quando o objeto "é inacessível para a percepção humana" 73 em virtude de seu tamanho, utiliza-se modelos com considerável alteração de escala: são as miniaturas e as ampliações. Elas são "recursos para promover uma aproximação do objeto muito grande, do muito pequeno, do tangível e do intangível [...]" 74 . Costumam ser construídas miniaturas de locomotivas e maquinário e ampliações de moléculas de DNA e de órgãos humanos, entre outros ${ }^{75}$. Nessas relações de escala, a ampliação do objeto "reduz" o observador, enquanto a miniaturização faz com que ele "cresça". Segundo Wagensberg, isso torna apenas a miniaturização bemsucedida na museologia, pois "Aceitamos tudo que nos coloca mais próximos da divindade, mas nos sentimos humilhados por uma tentativa de fazer o oposto" ${ }^{76}$.

Eventualmente essas miniaturas e ampliações, e também modelos de tamanho real, podem apresentar movimentos, ilustrando de forma mais efetiva o funcionamento de um sistema ou equipamento ${ }^{77}$.

Recursos audiovisuais têm sido utilizados há muito tempo para favorecer o entendimento dos conteúdos: gravações de som, slides, filmes comuns e em formatos especiais, apresentações de planetários, apresentações multimídia, etc. ${ }^{78}$

Os museus utilizam diversas mídias para comunicar suas mensagens, como "simulações de ambientes, fotografias, diagramas, legendas e textos", que são comuns a outros meios de divulgação. Entretanto, segundo Chelini e Lopes, “o objeto é o maior diferencial do museu" ${ }^{79}$ :

O objeto, segundo Van-Praët, é um trunfo didático essencial para maravilhar, espantar, questionar, e é o que dá à exposição sua especificidade frente a outras mídias de divulgação. Cury acrescenta, ainda, que o objeto

\footnotetext{
${ }^{73}$ WAGENSBERG, 2005a, p. 7.

${ }^{74}$ VALENTE, M. E. A., 2007, p. 12.

${ }^{75}$ DANILOV, 1982, p. 213.

${ }^{76}$ WAGENSBERG, 2005a, p. 7.

${ }^{77}$ DANILOV, 1982, p. 213.

${ }^{78}$ Ibidem, p. 215 e 241

${ }^{79}$ CHELINI; LOPES, 2008, p. 220. Grifo nosso.
} 
museológico é o elemento estruturador de uma exposição, [...] e, portanto, deve ser enfatizado, em detrimento de outros recursos museográficos. ${ }^{80}$

Jacomy acrescenta que:

[...] o objeto é tridimensional - uma dimensão a mais que a televisão, mas que faz uma grande diferença. Enquanto as exposições tendem a se tornar livros verticais ou televisões horizontais, o público se torna mais reticente e irá procurar outras mídias $[\ldots]^{81}$.

Wagensberg defende que "quanto mais alto o nível de realidade, melhor o item é para um museu". Um objeto original teria cem por cento de nível de realidade. Uma exposição com baixo nível de realidade poderia ser substituída “por vantagem e sem deixar a casa, por um bom livro, um bom filme, um bom som ou uma boa conexão de internet" ${ }^{82}$. Ela não explora as especificidades do ambiente do museu.

Segundo Van-Praet e Poucet, a linguagem é um dos elementos importantes da educação museal, e consiste em "informações que aparecem na forma de textos, imagens, aparatos interativos, objetos contemplativos, entre outros, [e] [...] têm a função de cativar o público, ensinar e divulgar conhecimentos" ${ }^{83}$. Os textos explicativos, em particular, devem ser "sintéticos, interessantes, claros e legíveis" 84.

Para atividades que visem crianças de 0 a 6 anos, entretanto, não podem ser utilizados textos, pois elas ainda não sabem $\operatorname{ler}^{85}$. Podem, sim, serem incluídas atividades lúdicas envolvendo simultaneamente letras, palavras, objetos e figuras para aquelas que já iniciaram seu processo de alfabetização.

\footnotetext{
${ }^{80}$ CHELINI; LOPES, 2008, p. 220.

${ }^{81}$ JACOMY, 2007, p. 24.

${ }^{82}$ WAGENSBERG, 2005a, p. 7.

${ }^{83}$ MARANDINO, 2008, p. 20.

${ }^{84}$ DANILOV, 1982, p. 204. A apresentação extensiva de conceitos em textos longos privilegia técnicas unidirecionais de comunicação, já superadas no ambiente museal e substituídas pela valorização das “experiências e informações prévias do público”. MARANDINO, 2008, p. 16-17.

${ }^{85}$ WAGENSBERG, 2008, p. 69.
} 
Na organização do museu de Wagensberg, ele produziu espaços especiais para duas faixas etárias: a das crianças entre zero e seis anos e entre seis e 10 anos, entendendo que eles têm características próprias que merecem uma abordagem específica ${ }^{86}$. Para os mais novos, o principal é o design. A água, por exemplo, é utilizada como um elemento que atrai fortemente os menores. Prevalecem as interatividades manual e mental, e a cooperação entre as crianças é estimulada. Nada é explicado se não for perguntado ${ }^{87}$.

Para as crianças de 6 a 10 anos as atividades são mais sofisticadas, funcionando como "uma preparação para a visita ao museu" ${ }^{88}$. A conversação e a compreensão são estimuladas com "atividades mais concretas, nas quais é preciso raciocinar mais" ${ }^{89}$. A estética para essa faixa etária já deve se aproximar mais daquela encontrada no restante do museu ${ }^{90}$. Apesar de criar espaços especiais para os mais novos, Wagensberg defende que "os espaços das crianças e dos adultos deveriam ser mais próximos, em todos os aspectos [...] [pois] é bom que crianças e adultos interajam em um mesmo espaço" ${ }^{91}$.

Com relação a esse mesmo público infantil, Marandino destaca a importância de apresentar

as informações centradas nos interesses da criança (como alguns aspectos práticos da visita: o que será mostrado, o que e onde comer, localização dos sanitários e bebedouros, etc.) [...] [de forma a] deixá-las muito mais relaxadas para voltarem sua atenção à exposição e aos seus mediadores (FALK e BALLING, 1982) ${ }^{92}$

\footnotetext{
${ }^{86}$ WAGENSBERG, 2008, p. 67.

${ }^{87}$ Ibidem, p. 68.

${ }^{88}$ Ibidem, p. 68.

${ }^{89}$ Ibidem, p. 68.

${ }^{90}$ Ibidem, p. 69.

${ }^{91}$ Ibidem, p. 71.

${ }^{92}$ MARANDINO, 2008, p. 21-22.
} 


\title{
4.3 Alguns temas museológicos
}

O desafio contemporâneo da museologia, e em especial da museologia das ciências e da tecnologia, é

\begin{abstract}
assegurar a função tradicional dos museus de preservar e estudar um patrimônio, material e imaterial, ao mesmo tempo em que enfrenta questões e relações criadas na atualidade pela ciência e tecnologia, que transformam em ritmo acelerado o ambiente da sociedade ${ }^{93}$.
\end{abstract}

Os Museus de História Natural e os de Ciência e Técnica - incluindo os Science Centers - parecem estar respondendo bem ao desafio, visto que têm sido, "em muitos aspectos, pioneiros na renovação da Museologia a que se tem assistido nas últimas décadas" ${ }^{94}$.

Diversos autores e novas idéias estão contribuindo para a formação das tendências atuais da museologia. Van Praet, por exemplo, apresenta a “museografia de sociabilidade", na qual um tema é repetido em diversos suportes diferentes de forma a favorecer a "cada membro do grupo a encontrar o suporte de sua escolha e, então, retornar ao grupo para dividir a experiência que acabou de viver e descobrir, assim, que os outros membros encontraram outros ângulos do mesmo assunto" 95 .

Em consonância com Van Praet, Chelini e Lopes, em virtude da heterogeneidade de público, defendem a existência de

\footnotetext{
um leque de opções, mesmo que todas referentes ao mesmo tema, que incluam interatividades, manipulações, contemplações, leituras, entre outras, [...] para promover acessibilidade e eficácia comunicacional de uma exposição. ${ }^{96}$
}

\footnotetext{
${ }^{93}$ VALENTE, M. E. A., 2007, p. 11. Ver também BRUNO, 2001, p. 267.

${ }^{94}$ GIL, 1988, p. 76. Ver também MONTANER, 1995, p. 125.

${ }^{95}$ VAN PRAET, 2005, p. 351-352.

${ }^{96}$ CHELINI; LOPES, 2008, p. 234.
} 
Na "museologia da idéia", defendida, entre outros, por Davallon ${ }^{97}$, a importância do visitante é enfatizada e, em conseqüência, busca-se facilitar a apreensão e interpretação dos conteúdos das exposições, em especial por meio da interatividade ${ }^{98}$.

Cury afirma que as
exposições de última geração [...] são aquelas cuja concepção enfatiza a participação criativa do visitante. Possuem caráter pentadimensional - a tridimensionalidade do espaço físico e dos objetos, a interatividade e 'a possibilidade que tem o usuário de redefinir a própria exibição' (Padilla, 1998:
3). 99

Para Danilov, uma boa exposição em um centro de ciências é aquela que "estimule e mantenha o interesse; envolva o público física e intelectualmente; apresente idéias e conceitos de forma inteligível; resulte numa experiência prazerosa; comunique a mensagem a que se propôs" ${ }^{100}$.

É comum dar-se grande destaque aos êxitos científicos, sem mostrar, entretanto, os inúmeros fracassos que os precederam ${ }^{101}$. Nesse sentido, Gil apresenta uma questão que nos pareceu bastante importante:

\footnotetext{
Sempre que possível, na apresentação de um conceito científico ou realização tecnológica, dever-se-á mostrar a evolução - por vezes lenta e penosa porque eles passaram até às suas formas atuais que, frequentemente, nos surgem hoje como evidentes, não o tendo sido, de modo algum, para os ossos antepassados, mesmo os mais inteligentes e esclarecidos ${ }^{102}$.
}

Outra questão fundamental é a da suposta neutralidade do museu, idéia que "é um resquício do modelo revolucionário francês que acreditava ser o museu o espaço

\footnotetext{
${ }^{97}$ DAVALLON, 2005, p. 358.

${ }^{98}$ VALENTE; CAZELLI; ALVES, 2005, p. 198-199.

${ }^{99}$ CURY, 2006, p. 47.

${ }^{100}$ DANILOV, 1982, p. 198. Tradução nossa.

${ }^{101}$ MORAIS, 2009, p. 21.

102 GIL, 1988, p. 88.
} 
neutro de concentração de objetos" ${ }^{103}$. Cury ${ }^{104}$ discorre sobre o tema a partir do estudo de diversos autores. O museu jamais é neutro, é uma instituição ideológica que procede à seleção de certos conceitos em detrimento de outros, e cuja visão apresentada é apenas uma das possíveis. Embora usualmente o público não seja alertado quanto a esta parcialidade do museu, seria importantíssimo que o fosse, pois, "quando adotam um discurso autoritário e distante, não revelando seus procedimentos, opções e dúvidas" ${ }^{105}$, os museus podem se tornar "instrumentos de dominação" ${ }^{106}$, tanto de ideologias de direita quanto de esquerda.

Outra questão importante a ser discutida é a relação entre o espaço arquitetônico e a exposição. "O tamanho, forma, altura, aberturas, e outros aspectos do ambiente proposto para uma exposição podem ter considerável influência em seu desenho. A maioria das exposições é projetada para um espaço específico" ${ }^{107}$. O contrário também ocorre: no projeto do edifício do museu um ambiente é projetado especialmente para uma dada exposição. Montaner afirma que, em um de seus modelos de museu - "O que se volta para si mesmo", há grande especificidade nos espaços de exposições:

\footnotetext{
Entende-se que a essência real do museu consiste em reconhecer as peças da própria coleção, conferindo-Ihes espaços à sua medida, conformes às suas características, como uma luva ou uma capa, ao mesmo tempo em que se aceita e reconhece o ambiente circundante ${ }^{108}$.
}

A classificação dos modelos de museus de Montaner será tratada no Capítulo 5, tópico 5.2 .

Essa abordagem pode ser muito bem-sucedida quando aplicada a coleções consolidadas - predominantemente artísticas ou históricas. Ela se afirmou com os

\footnotetext{
${ }^{103}$ CURY, 2006, p. 28.

${ }^{104}$ Ibidem, p. 28-30.

105 Ibidem, p. 30.

106 Ibidem, p. 30.

${ }^{107}$ DANILOV, 1982, p. 203. Tradução nossa.

${ }^{108}$ MONTANER, 2003, p. 76.
} 
museus italianos do pós-guerra, geralmente instalados em edifícios históricos e "com museografias dedicadas a coleções muito específicas, geralmente terminadas" 109. É preciso, entretanto, tomar cuidado em situações como a da maioria dos museus de ciências, nos quais as obras, não-originais, muitas vezes são trocadas, atualizadas, substituídas por outras de características diferentes, às vezes devido a avanços tecnológicos ou revisões de conceitos científicos. “É possível haver excesso de integração entre as exibições e a arquitetura. Nem todas as idéias de exibições são boas, e é realmente negativo concretizar uma má idéia de exibição em pedra" 110

Em pesquisa de Howarth e Medrano de $1997^{111}$, os representantes do California Science Center apontaram como o maior problema de seu museu o grande comprometimento com uma exposição que consiste numa mulher animatrônica de $15,25 \mathrm{~m}$ de altura, em virtude de se localizar em um nicho especificamente construído para ela no edifício do museu.

Por outro lado, o Cosmic Pathway, do Rose Center for Earth and Space do American Museum of Natural History, é uma bem-sucedida exposição que está intrinsecamente relacionada com o espaço arquitetônico: é um caminho helicoidal com 110 metros de comprimento em forma de tubo de aço de 9 metros de diâmetro que, ao mesmo tempo em que dá acesso à esfera no interior da qual estão o Space Theater e o Big Bang Theater, representa uma viagem de 13 bilhões de anos pela história do universo ${ }^{112}$. Na semi-esfera superior fica o primeiro, um planetário para 432 pessoas. Na semi-esfera inferior se localiza o segundo, “onde os espectadores ficam numa plataforma circular para ver os primeiros momentos de formação do universo em uma tela abaixo"113.

\footnotetext{
${ }^{109}$ MONTANER, 2003, p. 82.

${ }^{110}$ ANDERSON, 1991, p. 20 e 48. Tradução nossa.

${ }^{111}$ HOWARTH; MEDRANO, 1997, p. 20.

112 SIREFMAN, 2000, p. 42; LARSON, 1999, p. 105; FUTAGAWA, 2000, p. 48.

${ }^{113}$ LARSON, 1999, p. 105.
} 
A Cosmic Pathway, mesmo tendo sido concebida com base num saber científico consolidado, poderia até mesmo vir a assimilar novas descobertas e alterações de conceitos, bastando para isso alterar a posição de um display ao longo do percurso de $110 \mathrm{~m}$, acrescentar novos displays ou alterar o conteúdo dos existentes. Talvez essa inteligência de sua abordagem explique, em parte, o seu sucesso.

A questão da virtualidade, do material e do imaterial, abordada no Capítulo 3, tópico 3.1, se constitui numa questão a ser discutida. Segundo Montaner, a tendência à desmaterialização

tem suas raízes na arte contemporânea em obras de Malevich, Moholy-Nagy ou Duchamp. O objetivo é a dissolução do espaço, seja desmaterializando-se o contentor e realizando uma museografia que prescinda dos originais e se fundamente em dioramas e projeções, transparência e translucidez, réplicas e reproduções, seja recusando-se a colecionar objetos, mas apenas obras de arte audiovisual ou que escapem a qualquer suporte tradicional, ou ainda criando um museu virtual como base de dados ${ }^{114}$.

Várias dessas características são encontradas nos centros de ciência. Entretanto, neles, muitas vezes essa desmaterialização não é uma opção artística, mas prática, em vista da necessidade de apresentar conceitos que não se traduzem em peças originais, ou ainda pela inexistência de acervo desse tipo de objetos.

${ }^{114}$ MONTANER, 2003, p. 130. 


\section{ORIGENS E CONSIDERAÇÕES DIVERSAS}

\subsection{Origens e contexto histórico}

\subsubsection{O nome e a instituição museu}

Considera-se que a palavra "museu" tenha origem no termo grego mouseion, que significa "templo ou santuário das musas" ${ }^{1}$, e que se constituía num "lugar de inspiração onde a mente podia se desligar da realidade cotidiana". A primeira instituição com esta conceituação foi o Museu de Alexandria, que era uma instituição de ensino e pesquisa, na qual se encontrava a histórica Biblioteca². Entre outros, Euclides e Arquimedes foram pesquisadores nessa instituição, e o último participou do desenvolvimento de artefatos mecânicos. Alguns desses artefatos possuíam funções práticas evidentes enquanto outros podem ser considerados simples brinquedos, ou, como defende Ronan, podem ter sido criados para demonstrar princípios físicos ${ }^{3}$.

Pomian destaca a semelhança entre os museus da era moderna e contemporânea e os antigos templos gregos e romanos: eram os templos que recebiam as oferendas, que se tornavam objetos sagrados ${ }^{4}$. "Uma vez oferecidos aos deuses, em teoria, os objetos deviam ficar para sempre no templo que os tinha acolhido" 5 .

Uma outra associação ao nome museu é feita por Cury $^{6}$, com a figura mitológica de Museu, filho de Orfeu. Orfeu é o poeta, e Museu é aquele que recolhe "a poesia de Orfeu espalhada nas coisas", ato que se constitui no "olhar museológico".

\footnotetext{
${ }^{1}$ GASPAR, 1993, Capítulo II - Museus de Ciências. Breve Relato Histórico. Ver também POMIAN, 1997, p. 56.

${ }^{2}$ POMIAN, 1997, p. 56; GASPAR, 1993, Capítulo II - Museus de Ciências. Breve Relato Histórico.

${ }^{3}$ GASPAR, 1993, Capítulo II - Museus de Ciências. Breve Relato Histórico.

${ }^{4}$ POMIAN, 1997, p. 56.

${ }^{5}$ Ibidem, p. 57.

${ }^{6}$ CURY, 2006, p. 30.
} 


\subsubsection{Contexto histórico internacional}

[...] a partir do Paleolítico superior, o invisível encontra-se, por assim dizer, projetado no visível, pois desde então ele está representado no próprio interior deste por uma categoria específica de objetos: as curiosidades naturais e também tudo aquilo que se produz de pintado, esculpido, talhado, modelado, bordado, decorado... Por outras palavras, surge uma divisão no próprio interior do visível. De um lado estão as coisas, os objetos úteis [...]. De um outro lado estão os semióforos, objetos que não têm utilidade [prática] $[\ldots]$, mas que representam o invisível, são dotados de um significado $[\ldots]{ }^{7}$

E são, portanto, os semióforos, que apresentam interesse para a formação de coleções. "Na Idade Média as coleções acumulavam-se nas igrejas e nos tesouros dos príncipes" 8 , pois eram esses dois grupos, detentores do poder, que, segundo Pomian, monopolizavam os semióforos. É a partir de fins do século $X V^{9}$, com a consolidação de novos grupos sociais - humanistas, antiquários, artistas e cientistas $^{10}$ - que as "coleções de antiguidades formam-se e propagam-se" ${ }^{11}$.

Pomian descreve quatro categorias de semióforos. A primeira é a das antiguidades, citada acima, e que "Adquirem um significado a partir do momento em que são relacionados com textos provenientes da Antiguidade, dos quais devem tornar possível a compreensão" ${ }^{12}$. A segunda é a dos objetos exóticos à Europa, que passam a ser conhecidos a partir das viagens que se multiplicam no século XV: “tecidos, ourivesarias, porcelanas, fatos de plumas, 'ídolos', 'fetiches', exemplares de fauna e flora, conchas, pedras" tornam-se semióforos porque são "recolhidos não pelo seu valor de uso mas por causa do seu significado, como representantes do invisível: países exóticos, sociedades diferentes, outros climas" 13. A terceira categoria não é na realidade nova, mas passa a ter uma "dignidade que não tinha

\footnotetext{
${ }^{8}$ Ibidem, p. 78.

${ }^{9}$ Ibidem, p. 76.

${ }^{10}$ Ibidem, p. 78.

${ }^{11}$ Ibidem, p. 76.

12 Ibidem, p. 76.

${ }^{13}$ Ibidem, p. 77.
}

${ }^{7}$ POMIAN, 1997, p. 71. 
antes" a partir do século XV: quadros e obras de arte modernas. "Apenas a arte permite transformar o transitório em durável. Noutros termos: o que se representa tornar-se-á mais cedo ou mais tarde invisível, enquanto que a imagem, essa, permanecerá" ${ }^{14}$.

A quarta categoria de semióforos é a dos instrumentos científicos, que, a partir do século XVII, passarão também a se constituir em peças de coleção. Esses objetos, a partir da teoria matemática, devem permitir chegar a "conclusões infalíveis" sobre o invisível ${ }^{15}$, ou "adquirir conhecimentos históricos ou científicos" ${ }^{16}$. Essas peças comporão as coleções dos primeiros museus de ciência e tecnologia, tradicionais, com ênfase na história e em peças originais.

Durante os séculos XVII e XVIII, de forma geral as coleções eram particulares, não abertas à visitação popular ${ }^{17}$. "As únicas coleções acessíveis a todos são as das igrejas" ${ }^{18}$. Essa situação só vem a mudar com o surgimento e popularização dos museus, a partir de finais do século XVIII e especialmente nos séculos seguintes ${ }^{19}$.

Segundo Montaner, "A idéia de museu foi chave na definição dos conceitos de cultura e arte na sociedade ocidental" 20.

Paulette McManus procede a uma classificação histórica dos museus em três gerações, citada por diversos outros autores ${ }^{21}$. A essas três Padilla acrescentou uma quarta geração ${ }^{22}$. Uma classificação com diversos pontos comuns à de

\footnotetext{
${ }^{14}$ POMIAN, 1997, p. 76.

${ }^{15}$ Ibidem, p. 78.

${ }^{16}$ Ibidem, p. 54.

${ }^{17}$ Ibidem, p. 81.

${ }^{18}$ Ibidem, p. 82.

${ }^{19}$ Ibidem, p. 84.

${ }^{20}$ MONTANER, 2003, p. 9.

${ }^{21}$ MARANDINO, 2008, p. 15-16. PADILLA, 2001, p. 115-116. CHELINI; LOPES, 2008, p. 210; GIL, 1988. Van Praet faz restrições a essa classificação, considerando-a "às vezes redutora". VAN PRAET, 2005, p. 352.

${ }^{22}$ PADILLA, 2001, p. 116.
} 
McManus é a proposta por Allard e Boucher, separando em três etapas sucessivas os museus com foco em sua função educativa ${ }^{23}$.

Segundo McManus, a primeira geração de museus tem suas origens nos séculos XVII e XVIII, associadas às coleções particulares e aos Gabinetes de Curiosidades. Apresentam vínculos com a Academia e a Universidade, visam à conservação e exposição de objetos de valor intrínseco, normalmente apresentados exaustivamente, com a saturação típica dos Gabinetes. O enfoque é passivo, sem a possibilidade de manipular ou tocar os objetos. Integram a primeira geração os museus de história natural e aqueles voltados para coleções de instrumentos científicos ${ }^{24}$. As características dessa geração são bastante convergentes com as da primeira etapa da classificação de Allard e Boucher ${ }^{25}$.

Esses primeiros museus estavam associados à idéia da enciclopédia ${ }^{26}$, e à formação dos Estados modernos ${ }^{27}$. Segundo Jacomy, a origem dos museus também se relaciona com o "teatro das maquinas" da Renascença, que eram livros ilustrados com desenhos das técnicas descritas, incluindo "seções, esboços e modelagens" 28.

Sobre os Gabinetes de Curiosidades, Jacomy afirma que tinham três objetivos: experimentação (realização de experimentos), formação (educação pela demonstração) e recreação (espetáculo, entretenimento) e os três se faziam

\footnotetext{
${ }^{23}$ MARANDINO, 2008, p. 8-9. A primeira etapa tem início marcado pela fundação do primeiro museu público, o Ashmolean Museum, da Universidade de Oxford, em 1683. Os museus estavam inseridos em instituições formais de ensino, como as universidades. Na segunda etapa o público era mais amplo e de classes sociais diversificadas. Teve início nos finais do século XVIII e se desenvolveu ao longo do século XIX. Os "ideais democratizantes, inspirados na Revolução Francesa, fomentaram, por um lado, a abertura de mais museus [...] e por outro, a preocupação com o viés educativo das instituições”. A visita aos museus passou a ser considerada um complemento natural da educação formal. A terceira etapa foi de consolidação do papel educativo dos museus, ao longo do século XX, com ampliação e diversificação ainda maior de seu público. As exposições passaram a ter seus objetos criteriosamente selecionados para compor uma temática específica. Eram utilizados recursos típicos dos museus norte-americanos, como por exemplo, aparatos midiáticos e reconstituições de ambientes (dioramas), com o objetivo de facilitar a comunicação com o público e seu entendimento das temáticas apresentadas.

${ }^{24}$ Ibidem, p. 15; PADILLA, 2001, p. 115-116; CHELINI; LOPES, 2008, p. 210.

${ }^{25}$ MARANDINO, 2008, p. 8.

${ }^{26}$ GASPAR, 1993, Capítulo II - Museus de Ciências. Breve Relato Histórico; MONTANER, 1995, p. 124.

${ }^{27}$ MONTANER, 1995, p. 9.

${ }^{28}$ JACOMY, 2007, p. 16.
} 
presentes "na maioria dos museus fundados ao longo do século XIX" e a posteriori, nos centros de ciência da segunda metade do século $X X^{29}$.

Segundo Bittencourt, Benchetrit e Granato:

\begin{abstract}
Os primeiros museus surgiram como centros voltados para observar e estudar a natureza a partir de um olhar sistemático e racional. Coletavam objetos e organizavam suas coleções de modo a possibilitar, por meio de um exame metódico de exemplares recolhidos na natureza e na sociedade, um melhor entendimento do mundo. É esta, ainda em nossos dias, sua função básica como instituição ${ }^{30}$.
\end{abstract}

Gaspar acrescenta que "A Revolução Industrial e o progresso científico deram origem aos museus de ciências e tecnologia, enquanto que o impacto da teoria de Darwin influiu fortemente na proliferação de museus de história natural por todo o mundo" ${ }^{31}$. Gil também destaca o impacto da obra de Darwin na evolução dos Museus de História Natural ${ }^{32}$. Estes foram e continuam sendo instituições destinadas à aquisição, conservação, estudo e exposição de espécimes naturais, ainda que atualmente utilizem técnicas museográficas contemporâneas ${ }^{33}$.

Gil afirma que, apesar de terem existido “antigas coleções de máquinas e instrumentos científicos, nomeadamente [...] [de] propriedade dos Médicis" ${ }^{34}$, os antecedentes dos Museus de Ciência e Técnica, entretanto, "não foram coleções de 'curiosidades' de grandes senhores, tendo, pelo contrário, sido criados com fins essencialmente utilitários" ${ }^{35}$, em momentos mais recentes, durante a segunda geração.

Segundo Wittlin, entretanto, pequeno foi o sucesso dos primeiros museus ocidentais com relação à divulgação do patrimônio cultural apresentado, não

\footnotetext{
${ }^{29}$ JACOMY, 2007, p. 16-17.

${ }^{30}$ BITTENCOURT; BENCHETRIT; GRANATO, 2006, p. 12.

${ }^{31}$ GASPAR, 1993, Capítulo II - Museus de Ciências. Breve Relato Histórico.

${ }^{32}$ GIL, 1988, p. 75.

33 Ibidem, p. 73.

${ }^{34}$ Ibidem, p. 76.

${ }^{35}$ Ibidem, p. 76-77. Grifo nosso.
} 
conseguindo conquistar o público. Ao mesmo tempo em que o público não estava ainda preparado para a fruição daquele patrimônio, as instituições também não estavam maduras para apresentar suas coleções de forma organizada e interessante $e^{36}$

A segunda geração surgiu na virada do século XVIII para o XIX, "para atender às necessidades das indústrias [...] [pois] suas exposições, com caráter de demonstração, eram usadas na formação técnica daqueles trabalhadores que iriam operar as máquinas" ${ }^{37}$, ainda que pudessem atender também o público geral. Nessa geração foi inserida uma interatividade limitada ${ }^{38}$, do tipo "aperte o botão" 39.

Cronologicamente coincidente com a esta geração está a segunda etapa da classificação educativa de Allard e Boucher. Neste caso, o destaque é dado à maior "preocupação com o viés educativo das instituições" 40, constituindo-se em complemento natural da educação formal. Gaspar afirma que já no século XIX “A educação passou a ser entendida como a principal função dos museus públicos" ${ }^{41}$.

Segundo Valente, Cazelli e Alves, entretanto, foi nas três primeiras décadas do século $X X$ que se deu um processo real de escolarização dos museus, no qual eles abdicam de seu papel de centros de comunicação e cultura e se reduzem a complemento da educação formal ${ }^{42}$.

Segundo Valente, surgem na segunda metade do século XIX - em parte devido ao grande interesse despertado pelas exposições universais - museus com objetivo de

\footnotetext{
${ }^{36}$ GASPAR, 1993, Capítulo II - Museus de Ciências. Breve Relato Histórico.

${ }^{37}$ CHELINI; LOPES, 2008, p. 210.

${ }^{38}$ MARANDINO, 2008, p. 15; PADILLA, 2001, p. 116.

${ }^{39}$ PADILLA, 2001, p. 116.

${ }^{40}$ MARANDINO, 2008, p. 9.

${ }^{41}$ GASPAR, 1993, Capítulo II - Museus de Ciências. Breve Relato Histórico.

${ }^{42}$ VALENTE; CAZELLI; ALVES, 2005, p. 186.
} 
divulgação de conhecimento e de suas coleções ao grande público, tendência que se manteve e consolidou nos museus de ciência e tecnologia do século seguinte ${ }^{43}$.

No século XIX a Europa detinha a hegemonia mundial de conhecimento, recursos e poder, e, assim, procedia à conquista de territórios de países fora daquele continente. As exposições universais nasceram naquele século, apresentando matérias primas, novidades tecnológicas, produtos industriais e artísticos que refletiam seu desenvolvimento e a pujança da sua indústria ${ }^{44}$. Aquela foi uma época de "descobertas científicas e técnicas sem precedentes" ${ }^{45}$, que incluíam "as novas estradas de ferro, os teares mecânicos e as mais engenhosas invenções, que facilitavam a produção de praticamente todos os objetos que antigamente davam tanto trabalho aos artesãos [...]" ${ }^{46}$. Pevsner destaca, entretanto, a má qualidade do design da maioria desses objetos ${ }^{47}$.

As exposições universais terão importante impacto nos museus científicos, fornecendo objetos para suas coleções, e até mesmo pavilhões para sediá-los ${ }^{48}$.

A Exposição Universal de Londres, em 1851, no Hyde Park, foi a precursora, talvez porque o país fosse a primeira potência em escala mundial, com a Revolução Industrial ali já bastante consolidada ${ }^{49}$. The Great Exhibition of the Works of Industry of all Nations ${ }^{50}$, no original, marcou "o início da cultura dos grandes museus técnicos, do espetáculo dos objetos e do prestígio das ciências e artes aplicadas" ${ }^{51}$, tendo recebido seis milhões de visitantes em 120 dias $^{52}$.

Tem interessante relação com a história da arquitetura, por ter sido instalada num pavilhão especialmente construído que é um símbolo da nova arquitetura de ferro e

\footnotetext{
${ }^{43}$ CHELINI; LOPES, 2008, p. 207-208.

${ }^{44}$ PEVSNER, 1995, p. 27; VALENTE; CAZELLI; ALVES, 2005, p. 185.

45 PEVSNER, 1995, p. 27-28.

${ }^{46}$ Ibidem, p. 28.

${ }^{47}$ Ibidem, p. 33.

${ }^{48}$ MONTANER, 1995, p. 125.

${ }^{49}$ GIL, 1988, p. 77-78.

${ }^{50}$ GÖSSEL; LEUTHÄUSER, 1996, p. 21.

${ }^{51}$ MONTANER, 1995, p. 125.

${ }^{52}$ GASPAR, 1993, Capítulo II - Museus de Ciências. Breve Relato Histórico.
} 
vidro que vinha se consolidando desde os anos 183053: o Palácio de Cristal, de Joseph Paxton. Na época, era considerada apenas uma grande façanha de engenharia, sem valor artístico ${ }^{54}$, cujos objetivos técnicos eram a rapidez de construção e custo baixo ${ }^{55}$, além da possibilidade de ser desmontada e ter seus elementos reutilizados. Esses objetivos foram conseguidos através de uma préfabricação racional com montagem simples em um módulo ortogonal de $7,32 \mathrm{~m} x$ $7,32 \mathrm{~m}^{56}$. A estrutura foi, de fato, desmontada, mas reconstruída em Sydenham, em 1854, com algumas alterações significativas, como por exemplo, a introdução de uma abóbada cilíndrica na nave ${ }^{57}$.

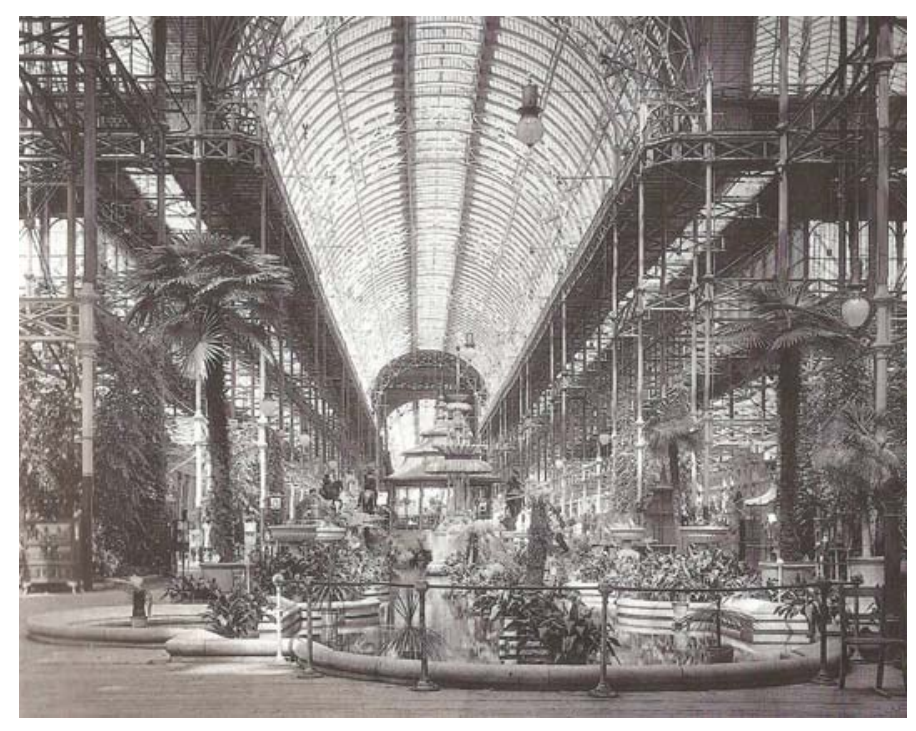

Fig. 02. Palácio de Cristal, de Joseph Paxton, depois de sua reconstrução em Sydenham, 1854. GÖSSEL; LEUTHÄUSER, 1996, p. 21.

Parte do conteúdo da Exposição de 1851 veio a compor o acervo do South Kensington Museum, origem comum do Science Museum e do Victoria and Albert Museum, em Londres ${ }^{58}$. Mas a influência da exposição foi muito mais significativa do que isso, tendo vindo a originar "uma onda de museus técnicos e industriais" ${ }^{59}$, que incorporaram diversas de suas características, que permanecem na museografia atual:

\footnotetext{
53 GÖSSEL; LEUTHÄUSER, 1996, p. 17.

${ }^{54}$ Ibidem, p. 17.

55 Ibidem, p. 18.

${ }^{56}$ Ibidem, p. 19.

${ }^{57}$ Ibidem, p. 21.

${ }^{58}$ MONTANER, 1995, p. 125; JACOMY, 2007, p. 18; GIL, 1988, p. 77.

59 JACOMY, 2007, p. 17.
} 
[...] no espaço, destinado ao atendimento de uma freqüência maciça, arquitetura e exposições formavam um todo a ser contemplado; o uso de publicações explicativas para orientação dos visitantes; a articulação de passado, presente e futuro; a preocupação com o aspecto visual do conjunto da exposição e com a adoção de diferentes recursos e meios técnicos para criar um ambiente agradável à visitação ${ }^{60}$.

Houve diversas outras exposições universais no século XIX, que vieram a "abastecer as coleções do Conservatoire des arts et métiers" ${ }^{61}$.

No que se refere aos museus de ciências que vieram a ser sediados em pavilhões construídos originalmente para feiras mundiais, relacionamos: a) The Museum of Science and Industry, em Chicago, sediado no Palace of Fine Arts da 1893 World's Columbian Exposition; b) The New York Hall of Science, em Nova Iorque, originado na World's Fair of 1964-65; e c) The Exploratorium em São Francisco, sediado no pavilhão da 1915 Panama-Pacific International Exhibition ${ }^{62}$.

A partir da 3ạ . Exposição Universal, realizada em Londres em 1862, o Brasil passou a participar desses eventos ${ }^{63}$.

A terceira geração de museus de ciências, originada na década de 1930, é aquela típica da segunda metade do século XX. De forma geral não há objetos de valor histórico intrínseco, mas aparatos interativos, visto que sua matéria prima não são mais a história ou a contemplação de objetos, mas as idéias, fenômenos e princípios científicos. Pressupõe-se a participação ativa do visitante, interagindo plenamente com as exposições, as quais priorizam a ciência e a tecnologia contemporâneas $^{64}$. O século $X X$ trouxe novos processos de trabalho, que acentuaram a modernização da sociedade. Somente através da educação, “um

\footnotetext{
${ }^{60}$ VALENTE; CAZELLI; ALVES, 2005, p. 185.

61 JACOMY, 2007, p. 17.

${ }^{62}$ DANILOV, 1982, p. 139.

${ }^{63}$ VALENTE; CAZELLI; ALVES, 2005, p. 185.

${ }^{64}$ MARANDINO, 2008, p. 16; PADILLA, 2001, p. 116; CHELINI; LOPES, 2008, p. 210.
} 
direito social de todos", o homem poderia se adaptar às novas exigências que lhe eram impostas ${ }^{65}$.

O tipo de museu descrito no parágrafo anterior é exatamente o que no Capítulo I chamamos de Centros de Ciência e Tecnologia, ou Science and Technology Centers.

Segundo Gaspar, a tendência à utilização de experimentos interativos de manipulação tem sua base teórica nas teorias de Piaget, as quais indicam que "a aprendizagem é fruto da interação ativa entre o aprendiz e os objetos", e o aumento da quantidade de centros de ciências interativos americanos está diretamente relacionado à difusão das teorias piagetianas naquele país ${ }^{66}$.

Gil afirma que o interesse americano pelos centros de ciências recebeu grande estímulo depois do lançamento do primeiro Sputnik, da União Soviética, em 1957. Ao mesmo tempo em que essa primeira derrota na chamada corrida espacial abateu o americano médio, levantou também a questão de seu baixo nível de conhecimento científico e tecnológico, além da sua falta de motivação para o engajamento em carreiras nessas áreas. Em resposta a essa situação, mais de $60 \%$ dos museus científicos e técnicos americanos foram criados após 1960, visando o cumprimento de alguns de seus objetivos típicos: divulgação científica e motivação ${ }^{67}$.

Segundo Valente, Cazelli e Alves, o surgimento dos Science Centers reforçou a tendência internacional de aumento de importância do papel de divulgação, motivação para carreiras e interatividade nos museus ${ }^{68}$. Gil afirma ainda que os museus de ciência e técnica, assim como os museus de história natural, "foram, em

\footnotetext{
${ }^{65}$ VALENTE; CAZELLI; ALVES, 2005, p. 186.

${ }^{66}$ GASPAR, 1993, Capítulo IV - Item 3.5 - Os centros de ciências e as teorias de aprendizagem.

${ }^{67}$ GIL, 1988, p. 81.

${ }^{68}$ VALENTE; CAZELLI; ALVES, 2005, p. 189.
} 
muitos aspectos, pioneiros na renovação da Museologia a que se tem assistido nas últimas décadas" ${ }^{69}$.

O surgimento no Brasil dos primeiros museus de ciência e tecnologia com caráter dinâmico na década de 1980 se deu como resultado do processo internacional citado no parágrafo anterior ${ }^{70}$. Nessa época, através de estudos e pesquisas podese verificar que ao mesmo tempo em que havia uma parcela da população interessada em assuntos científicos, baixa era a compreensão sobre ciência e tecnologia ("analfabetismo científico") ${ }^{71}$.

Os Science and Technology Centers são o resultado das experimentações de diversas outras instituições que se desenvolveram principalmente na Europa a partir da virada do século XIX para o XX: “museus de ciências, museus da técnica, museus industriais, museus da área de saúde, e museus de ciência e tecnologia" 72 . Os Science Centers se difundiram primeiro nos Estados Unidos, depois na Ásia $\mathrm{Gil}^{73}$ cita o Japão e a Índia-, e somente num terceiro momento, na Europa. “[...] neste como em muitos outros domínios as idéias e realizações do Velho Continente foram absorvidas e 'metabolizadas' além-Atlântico para, posteriormente, virem realimentar o pensamento e as realizações da Europa" ${ }^{74}$.

Muitos dos aparatos interativos produzidos originalmente por uma instituição foram reproduzidos por outras, "efetivando uma verdadeira indústria de museus interativos de ciência (Beetlestone et alii, 1998)" 75 .

Um aspecto a ser considerado é que, se nos primeiros museus de ciência e tecnologias o que predominava eram aparatos mecânicos - máquinas e equipamentos, no início do século $X X$ se difundiram a eletricidade $\mathrm{e}$ as

\footnotetext{
${ }^{69}$ GIL, 1988, p. 76.

${ }^{70}$ VALENTE; CAZELLI; ALVES, 2005, p. 189.

${ }^{71}$ Ibidem, p. 189-190.

${ }^{72}$ DANILOV, 1982, p. 2. Tradução nossa.

${ }^{73}$ GIL, 1988, p. 81.

${ }^{74}$ Ibidem, p. 81.

${ }^{75}$ VALENTE; CAZELLI; ALVES, 2005, p. 193.
} 
comunicações, o que transferiu a ênfase da materialidade da Mecânica para a imaterialidade, com grande influência nos "métodos de apresentação e de transmissão dos conhecimentos científicos e técnicos" ${ }^{76}$. Segundo Jacomy, essa nova situação teve impacto nos museus, transferindo o interesse maior "das técnicas para as ciências" 77.

A suposta falta de atenção aos contextos históricos e a difusão de uma falsa noção de que o progresso automaticamente seguiria a tecnologia são duas características negativas atribuídas aos Science Centers por autores como George Basalla ${ }^{78}$ e Edward P. Alexander ${ }^{79}$.

Padilla propõe ainda uma quarta geração, ainda por vir, na qual se dê não somente a participação ativa, mas criativa do visitante, com ênfase em "exibições de final aberto" ${ }^{80}$, e que se constituiria no museu de ciências do século XXI .

\subsubsection{Contexto Brasileiro do Século XX}

Na década de 1950 é criado no Brasil o Instituto Brasileiro de Educação, Ciência e Cultura (IBECC), por sugestão da UNESCO. O IBECC atuou inovando o ensino de ciências, promovendo a renovação do currículo escolar nas áreas científicas, fortalecendo o ensino experimental, inclusive com a montagem de kits portáteis ${ }^{81}$.

Mais ou menos ao mesmo tempo, a partir de 1956, o governo dos Estados Unidos passou a investir recursos e esforços no desenvolvimento de novos currículos, com

\footnotetext{
${ }^{76}$ JACOMY, 2007, p. 18.

77 Ibidem, p. 18.

${ }^{78}$ DANILOV, 1982, p. 10.

${ }^{79}$ Ibidem, p. 11.

${ }^{80}$ PADILLA, 2001, p. 116 e 131.

${ }^{81}$ GASPAR, 1993, Capítulo III - Museus e Centros de Ciências no Brasil. HAMBURGER, 2001, p. 33.

VALENTE; CAZELLI; ALVES, 2005, p. 187.
} 
o objetivo de melhorar a sua educação científica, a partir de críticas "surpreendentemente semelhantes às que se faziam no Brasil" ${ }^{82}$.

A UNESCO também atuou em outra iniciativa ligada ao desenvolvimento da Ciência no Brasil: patrocinou o "Projeto Piloto de Ensino de Física", em São Paulo, nos anos de 1963 e 1964, com a participação de diversos professores estrangeiros. Segundo Hamburger, essa ação levou à fundação dos primeiros Centros de Ciências do Brasil “dedicados principalmente ao treinamento de professores em serviço, e a encorajar atividades de observação e laboratório nas escolas" ${ }^{83}$. Essas instituições eram, portanto, bastante diferentes dos Science Centers americanos. Foram criadas seis unidades desses centros (CECl's) pelo Ministério da Educação e Cultura entre 1963 e 1965: Rio Grande do Sul, São Paulo, Rio de Janeiro, Minas Gerais, Bahia e Nordeste ${ }^{84}$.

Em 1966 foi criada a Fundação para o Desenvolvimento do Ensino de Ciências (FUNBEC), que atuou junto ao IBECC em projetos para o ensino de 1 ㅇ e $2 \stackrel{0}{\text { graus }}{ }^{85}$.

Segundo Gaspar, o projeto "Os Cientistas", de 1972, foi "a mais importante iniciativa voltada à divulgação científica desenvolvida no Brasil até os nossos dias". Invertendo o conceito dos CECl's, que visavam agir diretamente sobre os professores, a idéia era atrair crianças e adolescentes para a ciência e possibilitar que seu entusiasmo contagiasse colegas e professores. Isso seria conseguido através de uma "coleção de 50 kits contendo cada um a biografia de um cientista, um manual de instrução e material para a realização de experimentos" ${ }^{86}$.

Uma associação entre a FUNBEC e a Editora Abril viabilizou o projeto que, sob o ponto de vista editorial, foi um grande sucesso: sua primeira edição, Newton, vendeu 200.000 kits, as outras edições

\footnotetext{
${ }^{82}$ HAMBURGER, 2001, p. 34.

${ }^{83}$ Ibidem, p. 34.

${ }^{84}$ GASPAR, 1993, Capítulo III - Museus e Centros de Ciências no Brasil. VALENTE; CAZELLI; ALVES, 2005, p. 187.

${ }^{85}$ Ibidem, Capítulo III - Museus e Centros de Ciências no Brasil.

${ }^{86}$ Ibidem, Capítulo III - Museus e Centros de Ciências no Brasil.
} 
Na década de 1970 a ênfase se deu sobre a questão da consciência ecológica. “O ensino de ciências incorporou então um novo elemento, fundamental para atender a esse cenário: a educação ambiental e suas implicações sociais" ${ }^{88}$.

Na década de 1980 o IBECC e a FUNBEC perderam força em suas ações ${ }^{89}$. Por outro lado, em 1985 (governo José Sarney) foi criado o Ministério de Ciência e Tecnologia (MCT), fortalecendo a política dessas duas áreas no Brasil ${ }^{90}$ e “Em 1989 a Fundação Vitae passa a apoiar o ensino e os centros de ciências, dando uma contribuição importante" 91.

Em 2004 foi criada a "Semana Nacional da Ciência e Tecnologia" 92. Marandino cita o nascimento recente de diversas outras iniciativas, como a Política Nacional de Museus, o Sistema Brasileiro de Museus, o Cadastro Nacional de Museus, e o Observatório Nacional de Museus e Centros Culturais. Algumas dessas ações foram de caráter de sistematização de dados, enquanto outras envolveram destinação de recursos, eventualmente na forma de editais. São citados, especificamente, editais do MCT financiando, entre outras coisas, "a revitalização e o aprimoramento de espaços existentes" 93 (museus e centros de ciências).

\footnotetext{
${ }^{87}$ GASPAR, 1993, Capítulo III - Museus e Centros de Ciências no Brasil.

${ }^{88}$ VALENTE; CAZELLI; ALVES, 2005, p. 187.

${ }^{89}$ GASPAR, 1993, Capítulo III - Museus e Centros de Ciências no Brasil.

${ }^{90}$ CRESTANA, 2001, p. 626-627.

${ }^{91}$ HAMBURGER, 2001, p. 36.

${ }^{92}$ MASSARANI, 2008, p. 1.

${ }^{93}$ MARANDINO, 2008, p. 11.
} 


\subsubsection{Cronologia}

Nesse tópico apresentamos uma cronologia, com ênfase na criação de museus, tanto nacionais quanto estrangeiros. São feitos comentários adicionais, quando pertinentes, de forma a contextualizar os museus ou acontecimentos citados.

1635 - são criados, por Luís XIII, na França, o Jardin des Plantes e o Cabinet d'Histoire Naturelle. Estão associados à origem dos museus de história natural. Em 1794, passam a se chamar Jardin du Roi ${ }^{94}$.

1683 - é criado o primeiro museu público do mundo, o Museu Ashmoleano, da Universidade de Oxford, Inglaterra. Seu acervo tinha fins educativos. Hoje se chama Museu da História da Ciência ${ }^{95}$.

1734 - é aberto ao público o Museu Capitolino, em Roma, Itália - uma fundação papal $^{96}$.

1753 - é criado o Museu Britânico (British Museum), a partir da coleção de Sir Hans Sloane, e que incluía uma secção de história natural ${ }^{97}$.

1764 - instalação da coleção Ermitage em São Petersburgo, Rússia ${ }^{98}$.

1773 - é criado o Museu Clementino do Vaticano ${ }^{99}$.

1785 - é criado o Prado, em Madri, Espanha ${ }^{100}$.

Segundo Le Goff, as três situações anteriores não constituíam ainda museus públicos, mas "grandes coleções instaladas em edifícios especiais" ${ }^{101}$. A "era dos museus públicos e nacionais" 102 começaria com as primeiras realizações francesas da revolução, citadas a seguir.

\footnotetext{
94 GIL, 1988, p. 75.

95 GASPAR, 1993, Capítulo II - Museus de Ciências. Breve Relato Histórico; JACOMY, 2007, p. 16.

${ }^{96}$ POMIAN, 1997, p. 82.

${ }^{97}$ GASPAR, 1993, Capítulo II - Museus de Ciências. Breve Relato Histórico; GIL, 1988, p. 75;

POMIAN, 1997, p. 82.

${ }^{98}$ LE GOFF, 1997, p. 39.

99 Ibidem, p. 39.

${ }^{100}$ Ibidem, p. 39.

101 Ibidem, p. 39.

102 Ibidem, p. 39.
} 
1789 (Revolução Francesa) - a Convenção transforma os estabelecimentos criados por Luís XIII no Museum National d'Histoire Naturelle ${ }^{103}$.

1793 - é aberto o Louvre (Músee du Louvre), na França, com “pouca repercussão popular" ${ }^{104}$, após "tímidas" tentativas anteriores de abri-lo ao público entre 1750 e $1773^{105}$.

1794 - é criado em Paris, França, "como conseqüência da Revolução Francesa e por influência dos Enciclopedistas" ${ }^{106}$, o Conservatoire des arts et métiers, considerado o primeiro museu tradicional de ciência e técnica ${ }^{107}$. Visava, segundo Jacomy, "dotar a França de seus próprios recursos técnicos e pedagógicos de modo a competir no mercado industrial com outros países europeus" ${ }^{108}$, além de estimular a inovação ${ }^{109}$. Segundo Gil, tinha

\footnotetext{
dois objetivos principais: preservar a herança científica e tecnológica da civilização ocidental e, como função imediatamente utilitária, explicar a construção, uso e modo de operação das máquinas e outros instrumentos, não propriamente para o público em geral, mas para os artífices e outros trabalhadores mecânicos que delas necessitassem ${ }^{110}$.
}

O objetivo original do governo francês revolucionário, sob a influência do conceito da enciclopédia de Diderot, era criar um grande museu que concentrasse o conhecimento das artes e das ciências: seria o Muséum des arts et des sciences. Ao invés disso, entretanto, o que acabou se concretizando foi a criação dos três museus supracitados, entre 1789 e $1794^{111}$.

1818 - é criado por D. J oão VI o Museu Real - posteriormente renomeado Museu Nacional - como conseqüência da instalação da família real portuguesa no Brasil e inserindo-se no processo de modernização do país ${ }^{112}$. Foi o primeiro museu brasileiro. Tinha temática científica, voltado primordialmente para a história natural ${ }^{113}$. Segundo Gaspar, era uma "espécie de depositário de coleções e curiosidades, expostas sem qualquer classificação ou delimitação científica" ${ }^{114}$.

\footnotetext{
103 GIL, 1988, p. 75.

${ }^{104}$ GASPAR, 1993, Capítulo II - Museus de Ciências. Breve Relato Histórico.

${ }^{105}$ LE GOFF, 1997, p. 39.

${ }^{106}$ GIL, 1988, p. 75.

107 PADILLA, 2001, p. 114.

108 JACOMY, 2007, p. 16-17.

${ }^{109}$ Ibidem, p. 17.

110 GIL, 1988, p. 77.

111 JACOMY, 2007, p. 21.

${ }^{112}$ VALENTE; CAZELLI; ALVES, 2005, p. 185.

113 Ibidem, p. 184.

${ }^{114}$ GASPAR, 1993, Capítulo III - Museus e Centros de Ciências no Brasil.
} 
1824 - é criado o Franklin Institute, nos EUA ${ }^{115}$.

1830 - é criado o Museu das Antiguidades Nacionais em Berlim, Alemanha ${ }^{116}$.

1833 - é criado o Museu de Versailles ${ }^{117}$.

1846 - é criado o Instituto Smithsoniano, também nos EUA ${ }^{118}$.

1851 - The Great Exhibition of the Works of Industry of all Nations, primeira exposição universal, no Hyde Park, em Londres, Inglaterra.

1852 - é criado o Museu Germânico de Nuremberg, Alemanha ${ }^{119}$.

1852 - é criado o Museu das Manufaturas em Marborough House, Londres, Inglaterra ${ }^{120}$.

1857 - abertura do South Kensington Museum of Industrial Arts, na Inglaterra, que veio a originar em 1909, com a separação de sua coleção, o Science Museum e o Victoria and Albert Museum. Ao primeiro coube o acervo industrial, enquanto o segundo concentrou as belas artes ${ }^{121}$.

1859 - é criado o Museu Nacional do Bargello, em Florença, Itália ${ }^{122}$.

1862 - é criado o Museu de Saint-Germain por Napoleão ${ }^{123}$.

1866 - é fundado o Museu Paraense Emílio Goeldi, em Belém, Brasil, dedicado às ciências naturais ${ }^{124}$. A partir da década de 1920 entrou em decadência, em virtude da mudança de foco científico no país, que passou a priorizar as ciências aplicadas $^{125}$.

1869 - é criado o American Museum of Natural History, em Nova Iorque, EUA ${ }^{126}$.

\footnotetext{
115 PADILLA, 2001, p. 115.

${ }^{116}$ LE GOFF, 1997, p. 39.

117 Ibidem, p. 39.

${ }^{118}$ GASPAR, 1993, Capítulo II - Museus de Ciências. Breve Relato Histórico.

${ }^{119}$ LE GOFF, 1997, p. 39.

${ }^{120}$ Ibidem, p. 39.

121 JACOMY, 2007, p. 18; GASPAR, 1993, Capítulo II - Museus de Ciências. Breve Relato Histórico.

${ }^{122}$ LE GOFF, 1997, p. 39.

123 Ibidem, p. 39.

${ }^{124}$ VALENTE; CAZELLI; ALVES, 2005, p. 184-185.

${ }^{125}$ GASPAR, 1993, Capítulo III - Museus e Centros de Ciências no Brasil.

${ }^{126}$ AMERICAN, 2010.
} 
1881-1885 - a coleção de história natural do British Museum passa a constituir um novo Natural History Museum, permanecendo, entretanto, subordinado àquele museu $^{127}$.

1889 - é criado o Museu Austríaco de História Natural, em Viena ${ }^{128}$.

1891 - é criado o Museu de História Natural de Berlim, Alemanha, baseado na teoria de Moebius, que determinava uma separação entre a coleção científica (completa) e a exposição com vista ao público geral, parcial, pois criteriosamente selecionada a partir da primeira ${ }^{129}$.

1894 - é inaugurado o Museu Paulista (conhecido popularmente como “Museu do Ipiranga"), em São Paulo, Brasil, inicialmente voltado para as ciências naturais ${ }^{130}$. Também como o Museu Emilio Goeldi, passou por transformações a partir da década de 1920, tendo sua seção de biologia sido transferida para o Instituto Biológico e a de zoologia sido transferida para a Secretaria da Agricultura, vindo a originar, posteriormente, o Museu de Zoologia da USP. O próprio Museu Paulista foi integrado à USP em $1935^{131}$.

1903 - é criado por Oskar von Miller o Deutsches Museum em Munique, Alemanha, apresentando pela primeira vez a possibilidade de manipulação de parte dos objetos pelo visitante ${ }^{132}$, e constituindo-se também no primeiro museu dedicado exclusivamente à técnica ${ }^{133}$. Teve sua sede moderna projetada entre 1957 e 1961 por Paolo Nestler ${ }^{134}$.

1933 - é criado o Museum of Science and Industry, em Chicago, EUA, com quase 50 mil metros quadrados de área, "dando destaque à forma lúdica na apresentação de seus conteúdos", incluindo observação e experimentação ${ }^{135}$.

1937 - é aberto o Palais de la Découverte, em Paris, França, constituindo-se no pavilhão de ciência contemporânea da Exposição Universal de 1937, posteriormente integrado à Universidade de Paris.

\footnotetext{
127 GIL, 1988, p. 75.

${ }^{128}$ Ibidem, p. 75.

129 Ibidem, p. 75-76.

${ }^{130}$ VALENTE; CAZELLI; ALVES, 2005, p. 185.

${ }^{131}$ GASPAR, 1993, Capítulo III - Museus e Centros de Ciências no Brasil.

132 VALENTE; CAZELLI; ALVES, 2005, p. 193.

133 JACOMY, 2007, p. 18.

${ }^{134}$ MONTANER, 2003, p. 28.

135 GIL, 1988, p. 80; VALENTE; CAZELLI; ALVES, 2005, p. 193; GASPAR, 1993, Capítulo II Museus de Ciências. Breve Relato Histórico.
} 
O Museum of Science and Industry e o Palais de la Découverte "podem ser considerados como os pioneiros de um novo tipo de Museu nos domínios de que estamos tratando, designados, na nomenclatura de língua inglesa, sobretudo nos Estados Unidos, por 'Science Center'" ${ }^{136}$.

1947 - é fundado o Museo Nazionale della Scienza e della Tecnica Leonardo da Vinci, em Milão, Itália, com origens "na grande exposição científica e industrial, realizada naquela cidade em 1906". Como no caso do Deutsches Museum, mesmo numa época de carências do pós-guerra, considerou-se importante a criação de tal instituição, voltada para a conservação de patrimônio, a divulgação cultural e o estudo de métodos didáticos para a melhoria do ensino científico ${ }^{137}$.

1948 - é fundado o International Council of Museums (ICOM), tendo como seu primeiro presidente Georges-Henri Rivière ${ }^{138}$.

1957 - é criado o Museu do Instituto Butantã, em São Paulo, Brasil, com grande preocupação com sua função educativa ${ }^{139}$.

1969 - é criado o Ontario Science Centre, em Toronto, Canadá ${ }^{140}$.

1969 - é criado o Exploratorium de São Francisco, nos EUA, considerado o primeiro museu de ciências a utilizar maciçamente os experimentos interativos ${ }^{141}$. Suas exposições se baseavam "nos fundamentos das teorias cognitivas de aprendizagem e na perspectiva do 'aprender fazendo'" 142, com resultados positivos já bastante comprovados. Esse tipo de museu foi reproduzido em vários lugares do mundo ${ }^{143}$.

1973 - é criada, nos EUA, a Associação de Centros de Ciência e Tecnologia (ASTC) 144

1977 - é criado o Museo de la Ciência, da Fundação La Caja, em Barcelona, Espanha. É um centro de ciências “aberto ao público, a título experimental, no fim de 1980 e oficialmente inaugurado no ano seguinte" ${ }^{145}$.

\footnotetext{
${ }^{136}$ GIL, 1988, p. 80.

${ }^{137}$ Ibidem, p. 80.

${ }^{138}$ MARANDINO, 2008, p. 10.

139 GASPAR, 1993, Capítulo III - Museus e Centros de Ciências no Brasil.

${ }^{140}$ GIL, 1988, p. 81; PADILLA, 2001; p. 115.

${ }^{141}$ GASPAR, 1993, Capítulo IV - Item 3.2 - Objetos e experimentos - formas de expor e apresentar. Ver também QUIN, 1990, p. 243.

${ }^{142}$ MARANDINO, 2008, p. 11.

143 Ibidem, p. 11.

${ }^{144}$ DANILOV, 1982, p. 8; GASPAR, 1993, Capítulo II - Museus de Ciências. Breve Relato Histórico.

${ }^{145}$ GIL, 1988, p. 86.
} 
1981 - é criada a Coordenadoria de Divulgação Científica e Cultural (CDCC), da USP, em São Carlos, Brasil ${ }^{146}$.

1985 - é criado pelo CNPq o Museu de Astronomia e Ciências Afins do Observatório Nacional (MAST), no Rio de Janeiro, Brasil ${ }^{147}$.

1986 - é inaugurado o Cité des sciences et de l'industrie, no La Villette, em Paris, França, o maior centro de ciências do mundo.

1987 - é criada pelo CNPq / Ministério de Ciência e Tecnologia a Estação Ciência, em São Paulo, Brasil, e incorporada à USP poucos anos depois, em $1990^{148}$.

1987 - é criado o Museu Dinâmico de Ciências, em Campinas, Brasil ${ }^{149}$.

Os museus brasileiros criados na década de 1980 citados acima surgiram "no contexto dos processos de democratização do país" ${ }^{150}$, e são "os primeiros museus de ciência e tecnologia com caráter dinâmico, buscando se projetar como instituições de comunicação, educação e difusão cultural voltadas para um público amplo e diversificado" ${ }^{151}$, adotando "princípios pedagógicos construtivistas" ${ }^{152}$.

1991 - é inaugurado o Carnegie Science Center, em Pittsburg, EUA. Entretanto, originou-se da fusão entre o Carnegie Institute, cujos Museus de História Natural e de Arte remontam a 1895, e o Buhl Planetarium and Institute of Popular Science, criado em 1939, do qual herdou o equipamento ${ }^{153}$.

A década de 1990 trouxe novos centros de ciências brasileiros, especialmente o Museu de Ciência e Tecnologia (PUCRS), em Porto Alegre; o Espaço Ciência, em Recife; o Espaço Museu da Vida (FIOCRUZ), no Rio de Janeiro ${ }^{154}$.

Entre as novas instituições brasileiras dos anos 2000 podemos citar, de 2001 o Parque de Ciência e Tecnologia (USP), em São Paulo; de 2007, o Sabina, em Santo André (projeto do arquiteto Paulo Mendes da Rocha), e o Catavento Cultural, em

\footnotetext{
${ }^{146}$ GASPAR, 1993, Capítulo III - Museus e Centros de Ciências no Brasil.

${ }^{147}$ MARANDINO, 2008, p. 11; GASPAR, 1993, Capítulo III - Museus e Centros de Ciências no Brasil; HAMBURGER, 2001. p. 35.

${ }^{148}$ MARANDINO, 2008, p. 11; GASPAR, 1993, Capítulo III - Museus e Centros de Ciências no Brasil; HAMBURGER, 2001; p. 35.

${ }_{149}$ MARANDINO, 2008, p. 11.

${ }^{150}$ LOPES, M. M., 2009, p. 206.

${ }^{151}$ VALENTE; CAZELLI; ALVES, 2005, p. 189.

${ }^{152}$ MARANDINO, 2008, p. 11.

${ }^{153}$ CARNEGIE, 2010.

${ }^{154}$ VALENTE; CAZELLI; ALVES, 2005, p. 190.
} 
São Paulo. Em 2008 foi criada a Estação Cabo Branco, em João Pessoa, Paraíba, com projeto de Oscar Niemeyer.

5.20 museu enquanto novo tipo funcional ou programa arquitetônico

Introdução. Discussão sobre de tipo e tipologia.

Segundo Pereira,

a partir do século XVIII, tornaram-se bastante comuns os levantamentos de monumentos históricos, agrupando-os por tipologias, que tanto podiam ser ditadas pela função comum, quanto pela recorrência a um mesmo padrão formal. Certamente esse procedimento era sugerido pelos novos métodos científicos da época, em que a exposição conjunta dos espécimes era fundamental para a identificação de semelhanças e diferenças levando à sua classificação ${ }^{155}$.

Relacionam-se, portanto, com as idéias iluministas e enciclopedistas, assim como com o colecionismo e os gabinetes de curiosidades.

Por outro lado, a partir do final do século XVIII e durante todo o século XIX, deu-se a "aparição ou redefinição de numerosas tipologias funcionais, conseqüência das profundas transformações sociais, produtivas e tecnológicas", o que também é um fator a favorecer a difusão de abordagens tipológicas da arquitetura ${ }^{156}$. O Museu é uma dessas novas tipologias funcionais.

Entretanto, o conceito de tipo era impreciso até que J. N. L. Durand e Quatremère de Quincy, mais ou menos ao mesmo tempo, no início do século XIX, propuseram suas definições ${ }^{157}$. Ao longo do século $X I X$ as idéias de tipo e tipologia tiveram

${ }^{155}$ PEREIRA, 2005, p. 150. Grifos nossos.

${ }^{156}$ WAISMAN, 1990, p. 82.

${ }^{157}$ PEREIRA, 2005, p. 154. 
grande relevância, mas foram deixadas de lado durante o Movimento Moderno ${ }^{158}$, só voltando ao foco a partir do artigo de Argan de 1963 sobre tipologia ${ }^{159}$, tendo grande impacto em arquitetos como Aldo Rossi e Rafael Moneo ${ }^{160}$.

J. N. L. Durand ${ }^{161}$ procedia a uma abordagem tipológica sistematizada e didática ${ }^{162}$, coerente com o pensamento iluminista de sua época, e entendia tipo tanto como "a estrutura interna da forma arquitetônica quanto [como] o processo metodológico do projeto baseado na articulação de elementos e partes em planta e em fachada" 163. Pereira afirma que, "sua tipologia apoiava-se no levantamento histórico e concretizava-se em catálogos de prédios com funções ou partidos similares, em que ficavam evidenciados os padrões comuns" ${ }^{164}$. Se no segundo livro (que continha as tabelas tipológicas), ele "pretendia satisfazer as necessidades de sistematização do arquiteto projetista" 165 , no primeiro "pretendia tornar a história da arquitetura disponível para ele" ${ }^{166}$.

É o enfoque e o artigo de Quatremère de Quincy, no entanto, que terão maior influência na retomada do conceito de tipo, a partir da interpretação feita por Argan. A conceituação de tipo feita por Quincy é um pouco posterior à de Durand. Encontra-se em seu verbete Type, de 1825:

O modelo, entendido como parte integrante da validação prática de uma arte, é um objeto a ser imitado pelo que é; o tipo, por outro lado, é uma coisa com relação à qual pessoas diferentes podem imaginar obras que não têm uma semelhança óbvia entre si. Tudo é perfeito no modelo; no 'tipo' tudo é mais ou

\footnotetext{
${ }^{158}$ WAISMAN, 1990, p. 75.

${ }^{159}$ NESBITT, 2006, p. 267 e 273. . “On the Tipology of Architecture”, publicado originalmente em Architectural Design n. 33, dez. 1963, p. 564-565.

${ }^{160}$ OESCHLIN, 1986, p. 40; NESBITT, 2006, p. 267.

${ }^{161}$ Durand escreveu dois livros: Recueil et parallèle des tous les édifices anciens et modernes em 1800 um livro sobre história da arquitetura, e Précis des leçons em 1802, que continha tabelas de tipos edilícios.

162 OESCHLIN, 1986, p. 50.

${ }^{163}$ MONTANER, 2001b, p. 110.

${ }^{164}$ PEREIRA, 2005, p. 151

165 OESCHLIN, 1986, p. 50. Tradução nossa.

${ }^{166}$ Ibidem, p. 50. Tradução nossa.
} 
menos vago. Portanto, não existe nada na imitação de 'tipos' que desafie a influência do sentimento e da inteligência [...]. ${ }^{167}$

Montaner afirma que essa diferenciação proposta por Quatremère de Quincy pode ser considerada válida ainda hoje. “'Tipo' é a idéia genérica, platônica, arquetípica, é a forma básica comum da arquitetura; 'modelo' é aquilo que é possível ir repetindo tal qual, como um carimbo que possui uma série de caracteres recorrentes" ${ }^{168}$. E exemplifica:

\footnotetext{
um 'tipo' seria a arquitetura organizada ao redor de um pátio e, outro a casa de vizinhos separada por uma parede. E 'modelos', dentro do 'tipo' organizado ao redor de um pátio, seriam os pátios sevilhanos ou as agrupações agrárias francesas; dentro do 'tipo' de casa de vizinhos separada por uma parede, os modelos seriam os imóveis parisienses ou os blocos dos bairros Ensanche de Barcelona $^{169}$.
}

Argan defende que o tipo sintetiza as "soluções do passado", sendo resultado da “redução de um complexo de variantes formais à forma básica comum" ${ }^{170}$.

Nesbitt afirma que “A tipologia também pode ser considerada como um catálogo de soluções gerais para problemas de composição arquitetônica [...]. O tipo talvez constitua o que Derrida chamou de 'a arquitetura da arquitetura', ou o equivalente da estrutura profunda na linguagem" 171.

Aldo Rossi entende que "o tipo é a idéia mesma da arquitetura, o que mais se aproxima da sua essência", mas sempre enfatizando o urbano, a cidade, que a arquitetura ajuda a compor ${ }^{172}$.

I mpossibilitada de criar leis como as das ciências naturais, as ciências humanas ${ }^{173}$ constroem conceitos gerais para garantir certa ordem e estabilidade. $\mathrm{Na}$

\footnotetext{
${ }^{167}$ ARGAN, 2006, p. 269. Grifos nossos.

${ }^{168}$ MONTANER, 2001b, p. 110.

${ }^{169}$ Ibidem, p. 110.

${ }^{170}$ ARGAN, 2006, p. 270.

${ }^{171}$ NESBITT, 2006, p. 51. Grifo nosso.

${ }^{172}$ WAISMAN, 1990, p. 78; MONTANER, 2007, p. 104.
} 
arquitetura, o tipo é um desses conceitos gerais, que, para se conseguir uma análise profunda, deve levar em conta não somente os aspectos formais e funcionais, mas também os estruturais, de relação com o entorno, de emprego de técnicas ambientais; e abordá-los como uma rede de relações ${ }^{174}$.

Criação de novos tipos arquitetônicos

Tipos novos surgem associados a grandes mudanças ou inovações. Argan os associa à superação de soluções anteriores em novas situações históricas, socioculturais e tecnológicas, assim como demandas inteiramente novas ${ }^{175}$. Rafael Moneo, de forma similar, relaciona o surgimento de tipos aos momentos "quando ocorrem inovações estruturais e técnicas, mudanças funcionais e de escala, quando se solapam diversos tipos para se produzir outros novos [...]" ${ }^{176}$, ou, ainda, "quando o gênio do arquiteto é capaz de inventar, como ocorreu a Filippo Brunelleschi na intervenção da cúpula de Santa Maria del Fiore em Florença" ${ }^{177 .}$

Segundo Argan, o tipo não é, entretanto, criado intencionalmente, mas é resultado da verificação "da existência de uma série de construções que tenham entre si uma evidente analogia formal e funcional" ${ }^{178}$. Sua visão dos tipos históricos enfatiza as questões simbólicas, negando requisitos ou objetivos práticos, como a imitação dos tipos preexistentes, que constituiria uma suspensão do juízo histórico ${ }^{179}$. Não é consistente tentar associar tipologias formais às funções físicas da construção, ou seja, sob o aspecto tipológico, a forma não segue a função ${ }^{180}$. Fica clara a ênfase de Argan no aspecto formal - que se presta às associações simbólicas - inclusive

\footnotetext{
173 No original, “ciencias de la cultura”.

${ }^{174}$ WAISMAN, 1990, p. 75.

${ }^{175}$ ARGAN, 2006, p. 272.

${ }^{176}$ MONTANER, 2007, p. 105.

${ }^{177}$ Idem, 2001b, p. 124.

${ }^{178}$ ARGAN, 2006, p. 269.

179 Ibidem, p. 269 e 271.

${ }^{180}$ Ibidem, p. 270.
} 
quando ele define três categorias principais para os tipos formais arquitetônicos: configuração completa da construção; elementos estruturais básicos; e elementos decorativos. Essas categorias correspondem exatamente "à seqüência do processo de trabalho dos arquitetos (planta, sistema estrutural, tratamento da superfície)" 181

No século XVIII o museu é uma demanda funcional e programática nova. A partir da elaboração e execução de projetos para atender a essa nova demanda, soluções formais, estruturais, decorativas e simbólicas vão se apresentando e se afirmando, passando a constituir um novo tipo funcional ou institucional, relacionado ao museu.

\section{Tipo Funcional}

A partir de Morris é possível definir os "tipos funcionais" como associados "à tradição histórica e em particular aos predecessores funcionais de cada categoria institucional respectiva" ${ }^{182}$. Ela apresenta uma questão interessante para nossa discussão, que é a diferença do significado das palavras inglesas program e programme. O termo program, inventado por volta de meados do século XVIII, é o programa arquitetônico de necessidades, enquanto o programme, por outro lado, “representa requisitos implícitos. É a 'bagagem ideológica' por trás de qualquer edifício e, no que se refere à arquitetura institucional, representa as expectativas culturais gerais de tal edifício: [...] o que ele deveria representar em termos simbólicos principalmente" 183 - está relacionado ao conceito, ao partido arquitetônico, ou ainda à ideologia do arquiteto $^{184}$.

\footnotetext{
${ }^{181}$ ARGAN, 2006, p. 270.

${ }^{182}$ MORRIS, E.K., 1982, p. 17.

${ }^{183}$ Ibidem, p. 17.

${ }^{184}$ Ibidem, p. 17. 
Classificações tipológicas de museus: Montaner

Montaner afirma que

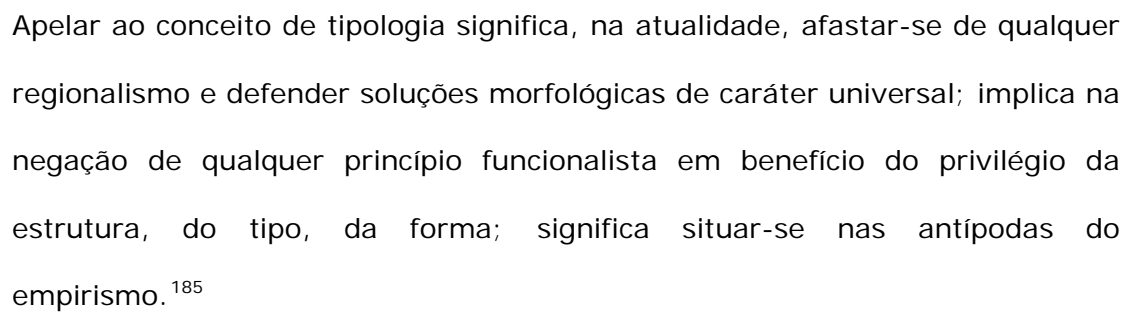

Entretanto, faz essa afirmação considerando mais a idéia de tipo ideal de Max Weber, que predominou durante o Modernismo ${ }^{186}$, do que o conceito geral de tipo e tipologia. O "tipo ideal" está mais próximo do conceito de modelo segundo Argan do que propriamente do conceito de tipo: "modelo implica [...] o reconhecimento de que determinada obra de arte é perfeita e deve ser imitada" ${ }^{187}$.

Essa relação entre "tipo ideal", modelo e o modernismo pode ser ilustrada considerando o surgimento, no período modernista, de quatro modelos de museu moderno: em 1939 o museu de crescimento ilimitado de Le Corbusier (forma retilínea que se enrosca); em 1942 o museu para uma pequena povoação de Mies Van der Rohe (museu platônico de planta livre); entre 1936 e 1941 o boîte em valise de Marcel Duchamp (um minúsculo museu portátil ou a idéia da total dissolução do museu); e finalmente, entre 1943 e 1959 o Museu Guggenhein de Nova Iorque, de Frank Lloyd Wright (forma orgânica e singular gerada por seu percurso helicoidal) ${ }^{188}$.

O próprio Montaner, em texto mais recente, propõe uma classificação dos museus contemporâneos em oito posições tipológicas, caracterizadas por "determinados mecanismos e estratégias formais", e por concepções distintas

\footnotetext{
${ }^{185}$ MONTANER, 2001b, p. 120.

${ }^{186}$ Ibidem, p. 111.

${ }^{187}$ ARGAN, 1963, p. 271.

${ }^{188}$ MONTANER, 2003, p. 10. 
no que se refere à organização do espaço interno, aos critérios museográficos de apresentação da coleção, à maneira de atribuir um valor emblemático e simbólico ao museu, à relação com o contexto urbano e com a paisagem ou ainda no que diz respeito aos materiais e às tecnologias ${ }^{189}$.

O Museu como Organismo Extraordinário. Esse tipo de museu "extraordinário", “irrepetível", “excepcional", "costuma acontecer em contextos urbanos consolidados, nos quais a obra sobressai como contraponto radical que pretende criar um efeito de choque" ${ }^{190}$. A arquitetura se torna escultura, o edifício se transforma em "espetáculo arquitetônico" ${ }^{191}$.

A Evolução da Caixa. Oposto ao "extraordinário", está associado a uma idéia moderna de museu, "que começa como armário ou caixa, como gabinete de colecionador ou câmara das maravilhas, como recinto ou continente básico" e depois chega a um "volume neutro, no qual a flexibilidade e os avançados serviços tecnológicos do espaço interior [...] facilitavam a resolução dos problemas" e facilitavam também os rearranjos ditados pelo crescimento das coleções ou pela evolução dos critérios museológicos. Este modelo atingiu bastante sucesso no programa dos museus da ciência e da técnica ${ }^{192}$. Os modelos de museu de Le Corbusier e Mies Van der Rohe, citados acima nesse mesmo tópico se inserem nesse tipo de museu ${ }^{193}$. "O momento crucial da evolução do museu como contêiner foi quando esta tradição da caixa eclodiu no edifício-massa do Centro Pompidou em Paris (1972-1977), de Renzo Piano e Richard Rogers [...]", que Montaner considera um grande "salto qualitativo", incluindo elementos de movimento (escadas, elevadores e passarelas) ${ }^{194}$ nos exteriores.

O objeto minimalista. "Os museus minimalistas [...] adotam formas bastante definidas de caixa. [...] são obras que recriam as formas mais essenciais e

\footnotetext{
${ }^{190}$ Ibidem, p. 12.

${ }^{191}$ Ibidem, p. 26.

192 Ibidem, p. 28.

${ }^{193}$ Ibidem, p. 29.

${ }^{194}$ Ibidem, p. 40.
}

${ }^{189}$ MONTANER, 2003, p. 10-11. 
estruturais e tentam ir mais além da evolução do tempo e dos recursos tecnológicos" ${ }^{195}$, que tem como exemplo famoso a pirâmide de vidro do Louvre ${ }^{196}$. Na estética minimalista "se incorporam obras de arte, museografia, contentor e entorno em uma mesma lógica de austeridade e de contundência [...]" 197, tendo atingido sucesso na reconversão de edifícios obsoletos e na organização de coleções complexas $^{198}$.

O "Museu-Museu". Essa posição tipológica está relacionada com a "eclosão da crítica tipológica, ou seja, de concepções baseadas nos valores históricos de cada disciplina" que se deu nos anos 1970. Nela se dá "uma maneira de projetar e intervir na qual toda a ênfase é colocada na essência da própria disciplina arquitetônica, na estrutura espacial do edifício, na tradição tipológica do museu, entendido como um arquétipo que vem se definindo e deve ter continuidade" ${ }^{199}$. Esse tipo de abordagem é o que mais se aplica em reconversões de edifícios préexistentes ${ }^{200}$.

O Museu que se volta para si mesmo. É o museu que enfatiza a especificidade dos espaços em relação aos seus acervos - um tema que foi discutido no Capítulo 4, tópico 4.3. A instituição reconhece as peças de sua coleção, conferindo-lhes espaços à sua medida ${ }^{201}$. Um exemplo dessa posição é a Fundação Iberê Camargo, em Porto Alegre, Brasil (projeto de 1998) 202.

O Museu Colagem. "O museu como colagem de fragmentos é expressão do triunfo da cultura de massas e é emblemático da implosão do museu". Ele passa a se constituir em edifício hedonista, popular, divertido, comunicativo, elemento-chave

\footnotetext{
195 MONTANER, 2003, p. 44.

196 Ibidem, p. 50.

${ }^{197}$ Ibidem, p. 60.

198 Ibidem, p. 60.

199 Ibidem, p. 62.

${ }^{200}$ Ibidem, p. 73.

${ }^{201}$ Ibidem, p. 76.

202 Ibidem, p. 77.
} 
da cidade, por vezes reforçando sua imagem urbana e turística ${ }^{203}$. "A condição contemporânea do museu, que deve ser continuamente ampliado, fomenta este caráter fragmentário e aditivo" ${ }^{204}$.

O Anti-Museu. Está relacionado com o modelo de museu de Marcel Duchamp, conforme citado anteriormente, e também com a idéia de um museu sem originais, somente com reproduções, sem sede física, que André Malraux propôs em 1951: um "Museu Imaginário". Essa posição está associada com a utilização de espaços não caracterizados como museus, ou mesmo com o recurso de instalações artísticas espalhadas pela cidade, por exemplo ${ }^{205}$.

Formas de Desmaterialização. Duchamp também influencia essa posição tipológica. A desmaterialização pode se dar através da "caixa transparente e leve até as formas que se espalham pelo espaço urbano ou que se camuflam por trás de outros edifícios", ou pela exploração de uma "museografia que prescinda dos originais", ou ainda da criação de museus virtuais ${ }^{206}$.

O objetivo da apresentação das posições tipológicas de Montaner não é tentar, no próximo Capítulo, encaixar cada uma das instituições estudadas nos diversas posições, mas levantar ou reforçar questões para discussão: o edifício como elemento extraordinário, marcante; a neutralidade da caixa; a relação específica entre arquitetura e museologia; a ampliação dos espaços físicos dos museus; a transparência; a desmaterialização; a virtualização.

\footnotetext{
${ }^{203}$ MONTANER, 2003, p. 94.

${ }^{204}$ Ibidem, p. 97.

${ }^{205}$ Ibidem, p. 110-128.

${ }^{206}$ Ibidem, p. 130. 
Os museólogos e a tipologia

Os museólogos também discutem a questão da tipologia, sob outro aspecto, particularmente dentro do campo dos museus. "Geralmente, as tipologias dos museus são definidas de acordo com a especificidade de seu acervo" 207 e das disciplinas às quais estão relacionados: Arte, História, Etnologia, Ciência e Técnica, etc. $^{208}$

\footnotetext{
Waldisa Russio, rompendo com essa classificação tipológica, sugere que as instituições museais sejam divididas em duas categorias: arte e ciência. Na categoria ciência, estariam incluídos os museus de ciências humanas e sociais e também os de ciências naturais e exatas; na categoria arte estariam os museus de belas artes, de arte moderna, de arte contemporânea e aqueles que se ofertam ao público pelo prisma estético. ${ }^{209}$
}

Chagas, entretanto, critica todo tipo de classificação tipológica de museus quando afirma que "seja ela qual for, além de ser fruto do arbítrio, não organiza a vida museal; quando muito, organiza o nosso pensamento sobre ela" 210.

Por outro lado, muitos outros autores utilizam diversos aspectos da tipologia para desenvolverem suas idéias e escreverem seus artigos. Moreira, por exemplo, propõe uma tipologia de museus locais divididos em quatro tipos ${ }^{211}$; Gouveia e Dodebei apresentam três tipologias de museus no ciberespaço ${ }^{212}$; e Montaner classifica os museus contemporâneos em oito modelos ou posições tipológicas ${ }^{213}$.

\footnotetext{
${ }^{207}$ GOUVEIA; DODEBEI, 2007, p. 94. Grifo nosso.

${ }^{208}$ CHAGAS, 2001, p. 52.

209 Ibidem, p. 53.

${ }^{210}$ Ibidem, p. 57.

${ }^{211}$ MOREIRA, 2007, p. 103-104.

212 GOUVEIA; DODEBEI, 2007, p. 96-97.

${ }^{213}$ MONTANER, 2003, p. 10-11.
} 


\section{3 Considerações arquitetônicas}

Segundo Lúcio Costa, "A mais tolhida das artes, a arquitetura é, antes de mais nada, construção". Mas é também, “igualmente arte plástica”, em virtude da sempre presente "margem final de opção entre os limites", que revela a "intenção plástica que [...] é precisamente o que distingue a arquitetura da simples construção" 214 . Assim, ele define arquitetura como

construção concebida com o propósito de organizar e ordenar plasticamente o espaço e os volumes decorrentes, em função de uma determinada época, de um determinado meio, de uma determinada técnica, de um determinado programa e de uma determinada intenção. ${ }^{215}$

Zevi, sem desconsiderar os demais aspectos da arquitetura, considera o espaço interior a sua essência. Esse vazio, onde "os homens andam e vivem" ${ }^{216}$, é "um fenômeno que se concretiza apenas em arquitetura e que desta constitui por isso a característica específica" ${ }^{217}$. Em concordância a Zevi, Reidy afirma que "o que realmente melhor a define [a arquitetura] e a caracteriza é a sua concepção espacial" ${ }^{218}$. E Tschumi afirma que "arquitetura é está relacionada com o espaço e com os eventos que ocorrem dentro dele" ${ }^{219}$, e que "o espaço é o que nós construímos" 220 .

Mas a obra arquitetônica não define apenas o espaço interior, mas compõem, segundo Zevi, juntamente com os demais edifícios contíguos, os espaços “exteriores ou urbanísticos” 221.

Montaner defende que, "Se a essência da arquitetura radica em suas qualidades espaciais, a análise arquitetônica deve tender a desvelar as estruturas ocultas que

${ }^{214}$ COSTA, 2005, p. 19-20.

${ }^{215}$ Ibidem, p. 21.

${ }^{216}$ ZEVI, 1992, p. 18.

${ }^{217}$ Ibidem, p. 23. Grifo nosso.

${ }^{218}$ CANAS, 2004, p. 103.

${ }^{219}$ TSCHUMI, 2000, p. 12. Tradução nossa.

${ }^{220}$ Ibidem, p. 13. Tradução nossa.

${ }^{221}$ ZEVI, 1992, p. 25. 
configuram e articulam cada edifício" ${ }^{222}$. Ele está falando da "estrutura espacial" ou “sistema compositivo" ${ }^{223}$, que tem um sentido "conceitual de lei formal básica" ${ }^{224}$. “É evidente que neste terreno existe uma relação entre estrutura espacial e sociedade" ${ }^{225}$. Um "espaço linear único" como o da biblioteca proposta por EtienneLouis Boullée em 1784 indica uma "visão unitária do mundo" ${ }^{226}$, enquanto numa "sociedade contemporânea fragmentada e diversificada" ${ }^{227}$ a arquitetura passará a “enfatizar o valor plástico dos elementos, a composição que articula dinamicamente fragmentos" 228 :

Esta relação entre estrutura espacial e sociedade foi muito evidente nos manifestos da arquitetura moderna. A planta livre e flexível, a fachada transparente, a estrutura aparente, a indiferenciação, a uniformidade e a igualdade características do antiespaço do movimento moderno queria ser o equivalente de uma sociedade moderna, igualitária, baseada na ética da sinceridade, da justiça e da economia, expressão da imagem científica de uma natureza livre. ${ }^{229}$

Zevi aborda a arquitetura moderna a partir das questões de espaço, volume e decorativismo:

[...] o movimento moderno, em sua magnífica tentativa de levar a arquitetura para o campo que Ihe é próprio, baniu a decoração dos edifícios, insistindo na tese de que os únicos valores arquitetônicos legítimos são os volumétricos e os espaciais. A arquitetura racionalista voltou-se para os valores volumétricos, enquanto o movimento orgânico se fixou nos espaciais. ${ }^{230}$

Considerando sua visão de arquitetura essencialmente como espaço, fica clara sua preferência pelo organicismo.

${ }^{222}$ MONTANER, 2001b, p. 114. Grifo nosso.

${ }^{223}$ Ibidem, p. 113.

${ }^{224}$ Ibidem, p. 113.

${ }^{225}$ Ibidem, p. 114.

${ }^{226}$ Ibidem, p. 114.

${ }^{227}$ Ibidem, p. 115.

${ }^{228}$ Ibidem, p. 115.

${ }^{229}$ Ibidem, p. 115. Grifo nosso.

${ }^{230}$ ZEVI, 1992, p. 26-27. 
Uma outra tese fundamental de Zevi é que o espaço não pode ser adequadamente representado por nenhum método de sua época ${ }^{231}$ (plantas, cortes, elevações, perspectivas, fotografias, filmes), e, portanto, só podem ser conhecidos e vividos "por experiência direta" 232.

Na busca da essência da arquitetura, Frampton, por outro lado, afirma que "a arquitetura deve necessariamente expressar-se na forma estrutural e construtiva" 233, considerando a “manifestação de uma estrutura potencialmente poética, no sentido original da palavra grega poiésis, como ato de criar e revelar" ${ }^{234}$. Ele declara explicitamente seu desacordo com a "tendência atual de reduzir a arquitetura à cenografia" 235 , como resultado do "triunfo generalizado do galpão decorado de Robert Venturi" ${ }^{236}$, e também com a "invenção do espaço como um fim em si mesmo" 237. Para Frampton, o "edifício é ontológico, uma presença ou uma 'coisa', e se distingue de um signo" ${ }^{238}$.

Nesbitt retoma a tríade vitruviana, e a associa a três elementos que "são frequentemente considerados indissociáveis da arquitetura: o tipo, a função e a tectônica" 239: Prazer (beleza ou forma ideal) - tipo; Comodidade (utilidade ou adequação) - função; e Firmeza (durabilidade) - tectônica ${ }^{240}$, ou estrutura física. Ela considera o tipo formal.

Diversos são os autores que fazem a associação direta entre forma e tipo, tipo e forma ${ }^{241}$. Em nosso entendimento, entretanto, conforme discutido anteriormente neste capítulo, no tópico 5.2, existem diversas abordagens relativas aos tipos: formal, funcional, estrutural, de relação com o entorno, de emprego de técnicas

${ }^{231}$ Zevi escreveu "Saber ver a arquitetura” em 1950.

232 ZEVI, 1992, p. 18.

233 FRAMPTON, 2006, p. 558.

234 Ibidem, p. 559.

235 Ibidem, p. 557.

236 Ibidem, p. 557.

237 Ibidem, p. 559.

238 NESBITT, 2006, p. 556.

239 Ibidem, p. 51.

240 Ibidem, p. 51.

${ }^{241}$ EISENMAN, 2006, p. 97. 
ambientais, etc. Portanto, a menção ao tipo não deve remeter diretamente à forma. O próprio edifício museu, por exemplo, é um tipo funcional, ao qual podem estar associadas tipologias formais e estruturais, e todas as demais existentes ou concebidas pelos teóricos da arquitetura.

Tschumi e Eisenman relacionam praticamente como sinônimos os termos programa, função e uso ${ }^{242}$. Tschumi acrescenta um quarto termo: conteúdo ${ }^{243}$. Em nossa visão, o programa está ainda mais diretamente associado não à função, mas à tipologia funcional, ou seja, o edifício museu, por exemplo caracteriza um programa ou uma tipologia ou tipo funcional.

De qualquer forma, programa “'é a descrição das dimensões espaciais, das relações espaciais, e de outras condições físicas necessárias para o desempenho adequado de funções específicas'" ${ }^{244}$, ou "um determinado grupo de acontecimentos esperados, uma lista de utilidades necessárias, freqüentemente baseadas no comportamento social, no hábito, ou nos usos e costumes" ${ }^{245}$, ou ainda, "uma lista das necessidades dos usuários descrevendo o propósito previsto para o edifício" ${ }^{246}$.

Discussão sobre forma e função

“A máxima arquitetônica de que 'a forma deve seguir a função' é a mais importante consideração no planejamento de um edifício de museu" ${ }^{247}$, segundo G. Ellis Burcaw. Danilov complementa:

Muitos edifícios de centros de ciência e tecnologia [...] foram construídos antes de serem determinadas quais exibições seriam neles colocadas. 0

\footnotetext{
${ }^{242}$ EISENMAN, 2006, p. 97; TSCHUMI, 2005, p. 11.

243 TSCHUMI, 2005, p. 11. No original, “content”.

${ }^{244}$ VIDLER, 2003, p. 63.

245 TSCHUMI, 2000, p. 13. Tradução nossa. Grifo nosso.

${ }^{246}$ Idem, 2005, p. 11.

${ }^{247}$ DANILOV, 1982, p. 141. G. Ellis Burcaw foi diretor e curador de museus.
} 
resultado foi uma perda de eficiência na utilização do espaço e efetividade na preservação das exibições ${ }^{248}$.

Mas a discussão sobre forma e função em arquitetura não é tão simples, nem consensual. Segundo Eisenman, nas teorias arquitetônicas "humanistas" mantémse "uma oposição dialética" entre a função ("distribuição interna" e "programa") e a forma ("articulação formal de temas ideais") ${ }^{249}$.

Reidy afirma que a arquitetura não pode ser dissociada de seu aspecto utilitário, mas que, por outro lado, "o simples fato de uma construção atender finalidades puramente funcionais não é condição suficiente para que mereça a designação de obra de arquitetura" 250 .

A afirmação de que "A forma segue a função" quer dizer que a função (ou programa) pode gerar a forma. Tschumi propõe uma colocação diferente: “concept follows content", ou "o conceito segue o conteúdo", sendo conteúdo sinônimo de função ou programa. A substituição de "forma" por "conceito" está em acordo com seu pensamento de que o que define a arquitetura é o conceito, e não a forma. ${ }^{251}$

O conceito de um edifício, entretanto, pode preceder a inserção de um programa ou conteúdo, desde que um contenedor neutro pode abrigar qualquer tipo de atividades. Inversamente, um dado elemento programático pode ser exacerbado ou tematizado de tal forma que ele se torna o conceito do edifício ${ }^{252}$.

Segundo Montaner, contemporaneamente, há, ao contrário, um “predomínio da forma sobre a função", denotada, por exemplo, pela reutilização de edifícios antigos com mudanças de uso ${ }^{253}$.

\footnotetext{
${ }^{248}$ DANILOV, 1982, p. 141.

249 EISENMAN, 2006, p. 97.

${ }^{250}$ CANAS, 2004, p. 103.

251 TSCHUMI, 2005, p. 12.

252 Ibidem, p. 12. Tradução nossa.

${ }^{253}$ MONTANER, 2001b, p. 112.
} 
Vidler vê também a "a possibilidade de repensar a noção de programa de um modo que feche o importante vazio modernista entre forma e função e incorpore preocupações ambientais, tecnologia, e invenção formal como importantes partes para um discurso único" ${ }^{254}$.

A arquitetura, o entorno e a cidade

Vidler dá destaque à questão da cidade, "pensada como um todo, seu passado e seu presente revelados em sua estrutura física. A cidade é em si e por si uma nova tipologia" ${ }^{255}$. Os "heróis" dessa nova tipologia são os

servidores profissionais da vida urbana, [que] dirigem suas habilidades de arquitetos para solucionar os problemas da avenida, arcada, rua e praça, parque e casa, instituição e serviço numa permanente tipologia de elementos que, juntos, se combinam com o tecido do passado e a intervenção do presente para criar uma experiência inteligível de cidade. ${ }^{256}$

Ele entende que a cidade e a tipologia (relacionada à cidade) são "as únicas bases possíveis para a restituição de um papel crítico a uma arquitetura que, de outra forma, acabaria sucumbindo ao ciclo aparentemente interminável de produção e consumo" 257.

Segundo Waisman, também Rossi enfatiza a cidade. “Rossi 'não se ocupa da arquitetura em si, mas da arquitetura como componente do fato urbano'" 258 , pois acredita que ela é construtora mesmo da cidade e dos espaços urbanos ${ }^{259}$. Waisman faz a ressalva de que, no caso, por exemplo, da maioria das cidades da América espanhola, isso não faria sentido em vista de elas terem sido planejadas a

\footnotetext{
${ }^{254}$ VIDLER, 2003, p. 74.

${ }^{255}$ Idem, 2006, p. 286-287.

${ }^{256}$ Ibidem, p. 288. Grifo nosso.

${ }^{257}$ Ibidem, p. 289.

${ }^{258}$ WAISMAN, 1990, p. 78. Tradução nossa. "Fato urbano” consta no original como "hecho urbano".

259 Ibidem, p. 78.
} 
partir de "um rígido esquema ortogonal" ${ }^{260}$. Mesmo nesses casos, entretanto, a arquitetura "pôde construir a imagem da cidade" ${ }^{261}$.

Lynch, em "A Imagem da Cidade" ${ }^{262}$, estuda-a com foco na sua percepção pelo cidadão, sua legibilidade. Defende que "legibilidade é crucial na estrutura citadina" ${ }^{263}$. Ela é uma qualidade visual da paisagem da cidade, sua “aparente clareza" ${ }^{264}$, ou seja, "a facilidade com a qual as partes podem ser reconhecidas e organizadas numa estrutura coerente” 265 . Ela “desempenha também um papel social [pois] pode fornecer a matéria-prima para os símbolos e memórias coletivas da comunicação entre grupos" 266 .

Outro conceito importante em Lynch é o de imagibilidade, "aquela qualidade de um objeto físico que Ihe dá grande probabilidade de evocar uma imagem forte num dado observador" 267.

Os elementos que vão ajudar a compor a legibilidade de uma cidade são cinco: "vias, limites, bairros, cruzamentos e elementos marcantes" ${ }^{268}$. Um elemento marcante pode ser "edifício, sinal, loja ou montanha" ${ }^{269}$, mas, para sê-lo, é necessário que tenha grande imagibilidade, que seja original, “memorável ou único num contexto" 270 , dintinguindo-se de uma "quantidade enorme de outros elementos" 271 e com "função constante de símbolo de direção" 272.

\footnotetext{
${ }^{260}$ WAISMAN, 1990, p. 78.

${ }^{261}$ Ibidem, p. 78. Grifo nosso.

${ }^{262}$ LYNCH, 1996.

263 Ibidem, p. 13.

264 Ibidem, p. 12.

265 Ibidem, p. 13.

${ }^{266}$ Ibidem, p. 14.

${ }^{267}$ Ibidem, p. 20.

${ }^{268}$ Ibidem, p. 57.

${ }^{269}$ Ibidem, p. 59. Grifo nosso.

${ }^{270}$ Ibidem, p. 59.

${ }^{271}$ Ibidem, p. 59.

272 Ibidem, p. 59.
} 
No caso de terem uma forma clara, os elementos marcantes tornam-se, ainda, mais fáceis de identificar; isto verifica-se, igualmente, quando contrastam com o cenário de fundo ou se localizam espacialmente num local predominante. ${ }^{273}$

O edifício se relacionada com a cidade a partir de um contexto. Esse contexto é indissociável da arquitetura real - ela está num terreno, dentro de um entorno com características históricas, geográficas, culturais, políticas e econômicas. Segundo Tschumi, sua visão de contexto é diferente daquela do "contextualismo" dos anos 1980 e 1990, que teria um "conservadorismo estético" associado à questão da “dimensão visual" 274 e da similaridade. Ele entende que, ao contrário,

arquitetura se conecta com seu contexto de múltiplas formas, e indiferença, reciprocidade, e conflito são todas relações válidas entre um edifício e seu entorno. [...] Uma estratégia de reciprocidade [...] pode significar que um edifício recebe indicações materiais de seu entorno sem mimetizar-se a ele. Alternativamente, materiais podem ser usados para fazer o edifício se destacar do seu contexto, para anunciar uma presença exótica ${ }^{275}$.

Tschumi acrescenta ainda que 0
contexto é algo definido pelo observador, da mesma forma que o fato científico é influenciado pela observação do cientista. [...] Contexto não é fato; é sempre uma questão de interpretação. [...] Contexto é freqüentemente ideológico e, em conseqüência, pode ser qualificado ou desqualificado pelos conceitos $^{276}$.

\footnotetext{
${ }^{273}$ LYNCH, 1996, p. 59-60.

${ }^{274}$ TSCHUMI, 2005, p. 11.

${ }^{275}$ Ibidem, p. 114.

${ }^{276}$ Ibidem, p. 12.
} 


\subsection{O programa funcional e observações pragmáticas}

Introdução

A arquitetura de um centro de ciências terá grande influência para o seu sucesso ${ }^{277}$

- ainda que, obviamente, não possa garanti-lo. Danilov destaca que:

$$
\begin{aligned}
& \text { Um edifício mal planejado ou sujo pode facilmente invalidar as melhores } \\
& \text { exposições e programas. Inversamente, um edifício bem projetado e } \\
& \text { conservado pode ter um impacto favorável no público, independentemente da } \\
& \text { qualidade das atividades do centro de ciências. }{ }^{278}
\end{aligned}
$$

Para que o edifício seja bem-sucedido do ponto de vista funcional - contribuindo para o sucesso da instituição que abriga - é necessário o estabelecimento de uma comunicação clara entre o arquiteto e a equipe do museu, em seus diversos níveis. O projeto será, em parte, resultado das informações apresentadas pela equipe: caracterização geral da instituição, público-alvo, objetivos, tipo de acervo, abordagem pedagógica, necessidades diversas. Quanto mais fiéis à realidade forem essas informações, melhor deverá ser o resultado concretizado no edifício ${ }^{279}$.

A exposição se caracteriza "pela transformação (organizada) do discurso elaborado pelos cientistas em saber a ser exposto e sua instalação espacial por arquitetos, designers e realizadores, podendo dessa forma caracterizar fortemente o produto final" ${ }^{280}$. Também sob o aspecto educacional a importância do espaço arquitetônico é ressaltada, pois “a aprendizagem pode ocorrer num diálogo constante entre o indivíduo e o ambiente" ${ }^{281}$, no qual se insere o "prédio" e os espaços onde se dão as atividades do museu ${ }^{282}$.

\footnotetext{
${ }^{277}$ HOWARTH, JR.; MEDRANO, 1997, p. 1; DANILOV, 1982, p. 57 e 143; ANDERSON, 1991.

${ }^{278}$ DANILOV, 1982, p. 143. Tradução nossa.

${ }^{279}$ HOWARTH, JR.; MEDRANO, 1997, p. 1, 40-43; DANILOV, 1982, p. 138.

${ }^{280}$ MARANDINO, 2005, p. 173.

${ }^{281}$ Idem, 2008, p. 21-22.

${ }^{282}$ PADILLA, 2001, p. 122.
} 
Padilla vai mais além, afirmando que os espaços "também podem ser elementos educativos por si mesmos, ao propiciar que o público valorize conscientemente ou inconscientemente a beleza, a ordem, a limpeza e a funcionalidade [...]" ${ }^{283}$.

Localização

A adequada caracterização da instituição deverá impactar tanto na conceituação do edifício quanto na definição de sua localização - igualmente importante. Genericamente uma localização central seria mais apropriada, devido às condições de acesso. Entretanto, os terrenos podem ser muito caros ou até inexistentes, dificultando sua implantação e possível expansão posterior. Centros de ciências com enfoques ambientais ou naturais podem necessitar de áreas verdes e espaços abertos que são mais prováveis de serem encontrados em locais periféricos ${ }^{284}$. Por outro lado, a implantação de um "centro de ciências em um terreno ecologicamente frágil seria difícil de defender a menos que ele pudesse agir na preservação e proteção da área, ou incorporar a ecologia local em seus programas" 285.

Tschumi coloca ainda outra questão sobre o assunto:

A construção de um aeroporto dentro de uma reserva natural ou um shopping center em um distrito histórico são exemplos familiares de justaposições polêmicas de contexto e conteúdo [programa, função]. Ainda assim, tais oposições podem levar a conceitos arquitetônicos ou sociais desafiadores ${ }^{286}$.

Além disso, é necessário pensar no público que se deseja atender, o que pode indicar a escolha de áreas não centrais como forma de responder às suas carências de infra-estrutura cultural.

\footnotetext{
${ }^{283}$ PADILLA, 2001, p. 122.

${ }^{284}$ DANILOV, 1982, p. 56-57 e 138.

${ }^{285}$ ANDERSON, 1991, p. 73.

${ }^{286}$ TSCHUMI, 2005, p. 12. Tradução nossa.
} 
A maior parte das pessoas que visitam centros de ciência o faz como resultado de uma decisão consciente, e não em virtude de um passeio pelas redondezas ou de uma visita a algum estabelecimento ou instituição vizinha. “Visitantes potenciais precisam saber da existência do centro, querer vir, e ter condições de fazê-lo. O local deve, em conseqüência, ser tão atraente, acessível e seguro quanto possível" 287. Essa segurança deve ser não só real quanto aparente, explícita, de forma a não afugentar o visitante, especialmente à noite, quando costumam se dar parte das atividades de um centro de ciências: shows, eventos, festas, jantares ${ }^{288}$.

No que tange à localização e ao entorno, um outro aspecto a se considerar são as eventuais instituições vizinhas. Parques e jardins botânicos são "bons vizinhos", pois ao mesmo tempo em que atraem público, não competem diretamente com um centro de ciências. Essa influência positiva é mais significativa em centros de ciência menores ${ }^{289}$.

Anderson, considerando o contexto norte-americano, afirma que a maior parte dos visitantes chega por automóveis particulares, ônibus escolares ou ônibus de turismo. O transporte público seria importante especialmente em cidades de maior porte. Em vista disso, destaca a necessidade de vagas de estacionamento suficientes para atender ao pico de quantidade de veículos, considerando ainda a possibilidade do entorno de absorver veículos excedentes, em caso de necessidade ${ }^{290}$.

\footnotetext{
${ }^{287}$ ANDERSON, 1991, p. 23.

288 Ibidem, p. 24.

289 Ibidem, p. 24.

290 Ibidem, p. 23. 
Ordem de grandeza do centro de ciências

Daniel Traverso classifica os centros de ciências em pequenos, médios e grandes, a partir da metragem de seus edifícios. Um centro de ciências pequeno teria entre $2.000 \mathrm{~m}^{2}$ e $4.500 \mathrm{~m}^{2}$; o médio entre $4.500 \mathrm{~m}^{2}$ e $9.500 \mathrm{~m}^{2}$; e o grande entre 9.500 $\mathrm{m}^{2}$ e $55.000 \mathrm{~m}^{2}$. Considera, entretanto, a possibilidade de um centro com 1.000 $\mathrm{m}^{2}$ ser bem-sucedido ${ }^{291}$. Anderson, entretanto, ressalta que um centro realmente pequeno só se torna viável economicamente a partir de fatores como a doação do edifício e de recursos financeiros e a participação maciça de voluntários ${ }^{292}$.

Por esse motivo, a implantação de um centro de ciências em fases, ainda que possível, requer algo como um "tamanho mínimo" inicial ${ }^{293}$.

O edifício

\begin{abstract}
Ter um edifício novo pode ser uma grande vantagem, pois ele pode ser desenhado especificamente para se adequar aos objetivos e à situação [da instituição]. Frequentemente, entretanto, a própria idéia do centro de ciências surge em conexão com um edifício ou uma área existente. Não há nada de errado com isso, desde que sua localização seja satisfatória, e as funções essenciais possam ser acomodadas no edifício existente ${ }^{294}$.
\end{abstract}

O edifício deve ser "flexível, eficiente, e relativamente fácil e barato para conservar" 295. Danilov enfatiza o aspecto funcional sobre o estético. Anderson, por outro lado, destaca que um edifício marcante ${ }^{296}$, seja novo ou reconvertido, atrai “propaganda gratuita", patrocínios e eventos geradores de renda como recepções, casamentos,

\footnotetext{
${ }^{291}$ DANILOV, 1982, p. 142.

292 ANDERSON, 1991, p. 14.

293 Ibidem, p. 14.

${ }^{294}$ Ibidem, p. 17-18. Ver também DANILOV, 1982, p. 57 e 137.

${ }^{295}$ DANILOV, 1982, p. 137. Tradução nossa. Ver também HOWARTH, JR.; MEDRANO, 1997, p. 3.

${ }^{296}$ No original, “grand and distinctive building”. Ver também a p. 111 da presente dissertação: Lynch, elemento marcante.
} 
entre outros ${ }^{297}$. Howarth, Jr. e Medrano ${ }^{298}$ apresentam, nas priorizações de projeto, uma oposição entre o edifício marcante ${ }^{299}$ e o edifício eficiente $e^{300}$.

Nem sempre a reciclagem ou reconversão de um edifício existente é mais barata do que a construção de um novo ${ }^{301}$. Além disso, o custo de manutenção e operação desses edifícios também deve ser considerado e comparado com o de um novo.

Algumas vezes é um processo de duas fases, com o centro de ciências sendo aberto num edifício convertido enquanto se busca fundos para [a construção de] uma nova estrutura. Mas essa tática pode ter resultado inverso se a operação inicial for um desapontamento para os doadores potenciais ${ }^{302}$.

\section{Programa}

Para o dimensionamento dos espaços, é preciso considerar alguns indicadores pesquisados: a) nos dias de pico a visitação é aproximadamente 10 vezes maior que a dos dias com menos visitantes; b) dez por cento dos visitantes anuais vêm nos 15 ou 20 dias de pico; c) durante um dia, até a metade dos visitantes estão no local no horário diário de pico, por volta de 13 h30 $\mathrm{min}^{303}$. "A maioria dos visitantes está presente quando o centro está cheio. É para essa situação que se projeta, e não para a média" 304 .

As áreas de entrada têm como funções a entrada geral, embarque e desembarque de visitantes provenientes de automóveis e ônibus, ponto de encontro, descanso e espera, informação, possível local para exibição promocional. O acesso da parada de ônibus até o edifício deve ser coberta, assim como os locais das filas para

\footnotetext{
${ }^{297}$ ANDERSON, 1991, p. 26.

${ }^{298}$ HOWARTH, JR.; MEDRANO, 1997, p. 3.

${ }^{299}$ No original, "landmark building”, um edifício que se torna um marco de referência.

300 Ou funcional.

${ }^{301}$ ANDERSON, 1991, p. 17-18.

${ }^{302}$ DANILOV, 1982, p. 57. Tradução nossa.

303 ANDERSON, 1991, p. 28-29.

${ }^{304}$ Ibidem, p. 28-29.
} 
embarque nos ônibus. Os fluxos de entrada e saída devem ser separados. Anderson ${ }^{305}$ sugere a existência de uma cabine móvel para vendas de tíquetes em dias de pico e de um espaço bastante visível com ponto de energia para apresentar um elemento que funcione como publicidade para uma exposição temporária.

Considerando a importância e peculiaridades dos grupos escolares, Anderson ${ }^{306}$ levanta a possibilidade da existência - como de fato ocorre em alguns centros de ciências - de uma entrada separada para esses grupos. Entretanto, ele mesmo comenta que a mesma não é indispensável, visto que "as visitas de escolas ocorrem normalmente quando a visitação geral é mínima" e que a entrada separada privaria os grupos da "experiência da entrada monumental". De qualquer forma, há alguns procedimentos especiais para o atendimento de grupos escolares que devem ser considerados: local para o registro da turma pelo professor ("check in"), sanitários, local para lanches, e eventualmente serviços complementares como salas de aula ${ }^{307}$. Para a concepção dos espaços envolvidos é necessário considerar que os grupos costumam ter até 40 pessoas, e suas visitas levam em torno de 3 horas $^{308}$.

O saguão de recepção e orientação - o foyer - é extremamente importante para a impressão geral do visitante. Considerando que todo o visitante passa por ele, é natural que em horários de pico de entrada e saída o mesmo apresente grande número de pessoas, motivo pelo qual especial atenção deve ser dada quanto à sua absorção sonora. Os grupos - escolares e outros - precisam de numerosos sanitários ao chegar e de espaços para guardar seus casacos e lanches ${ }^{309}$.

Anderson sugere uma solução de "pré-show" para os casos em que os visitantes vão enfrentar filas para assistir a alguma atração: o visitante aguarda numa sala

\footnotetext{
${ }^{305}$ ANDERSON, 1991, p. 41-42.

${ }^{306}$ Ibidem, p. 41-42, 50-51.

${ }^{307}$ DANILOV, 1982, p. 270.

${ }^{308}$ ANDERSON, 1991, p. 50-51; DANILOV, 1982, p. 273.

${ }^{309}$ ANDERSON, 1991, p. 43-44.
} 
que comporte a mesma lotação da sala principal, na qual acontece o "pré-show", para depois entrar em um cinema, teatro ou sala de apresentação. O "pré-show" tem que ser pensado de forma a que possa ser interessante mesmo para quem chegar após o seu início 310 .

As áreas de exposição representam a essência arquitetônica de um museu ou centro de ciências ${ }^{311}$. Suas dimensões influem em seu custo de manutenção, no controle de luz, som e odores, na criação de diferentes ambientes e na versatilidade. Áreas grandes são mais versáteis, enquanto espaços menores são melhores para os demais itens citados $^{312}$.

Uma reclamação comum dos visitantes de centros de ciência é o barulho, que "reduz a [sua] satisfação [...] e abrevia sua visita" ${ }^{313}$. Por isso, uma das preocupações centrais do projeto arquitetônico deve ser buscar o conforto sonoro, através da diminuição do tempo de reverberação ${ }^{314}$. Um dos requisitos para uma "experiência compensadora e motivadora", segundo Csikzentmihalyl, é a "possibilidade de concentrar-se na tarefa a ser realizada" ${ }^{315}$.

Durante a segunda metade do século XX os projetos de edifícios de museus têm bloqueado a luz natural numa tentativa de reduzir o ofuscamento, o aquecimento excessivo, as distrações e os seus efeitos nocivos para a conservação de alguns tipos de objetos originais ${ }^{316}$. Entretanto, novas abordagens de projeto incluem iluminações zenitais com vidros especiais que bloqueiam parte do espectro da luz, permitindo iluminação natural sem ofuscamento ou calor excessivo ${ }^{317}$. Howarth, Jr. e Medrano indicam a tendência contemporânea da substituição das "caixas pretas" por espaços onde a iluminação natural controlada possa proporcionar maior

\footnotetext{
${ }^{310}$ ANDERSON, 1991, p. 43-44.

${ }^{311}$ Ibidem, p. 47.

${ }^{312}$ Ibidem, p. 47-48. DANILOV, 1982, p. 142.

${ }^{313}$ HOWARTH, JR.; MEDRANO, 1997, p. 14. Tradução nossa.

${ }^{314}$ Ibidem, p. 14.

${ }^{315}$ STUDART, 2003, p. 36-37.

${ }^{316}$ ANDERSON, 1991, p. 78-84; CANAS, 2004, p. 116.

${ }^{317}$ Ibidem, p. 78-84.
} 
satisfação e conforto ao visitante ${ }^{318}$. Há também a questão do uso racional de energia, que não é só econômica, mas atualmente ganha status de afirmação ecológica.

As cores das paredes também têm impacto significativo no efeito geral da luz. $O$ uso de cores claras, por exemplo, melhora o rendimento energético da iluminação. Efeito semelhante tem o uso de novas tecnologias como "sun-tracking collectors", fibras ópticas e "light pipes" 319

Anderson destaca, entretanto, que o aumento do número de janelas, ou de suas dimensões, é um "tremendo problema energético", pois o "vidro simplesmente não isola tão bem quanto as paredes podem isolar". O autor cita a utilização de filmes aplicados nos vidros - que devem variar de acordo com a latitude do local - como forma de minimizar esses problemas, propiciando a reflexão de calor e de radiação ultravioleta ${ }^{320}$.

A dimensão vertical da sala de exposição - seu pé direito - pode também possibilitar arranjos múltiplos para as exposições. Pés direitos altos (acima de $7 \mathrm{~m}$ ) podem possibilitar a execução de mezaninos, a colocação de grandes objetos pendurados no teto e provocar uma sensação de amplitude. Por outro lado, exigem maior potência de equipamentos de condicionamento de ar - cuja necessidade é comum em salas de exposição ${ }^{321}$. Entretanto, para o controle natural de temperatura em climas quentes, nos casos em que ele é possível, o alto pé-direito poderá ser um facilitador. Pés direitos baixos - não muito menores do que $4 \mathrm{~m}$-, além de mais econômicos para o condicionamento de ar podem ser até mais adequados para alguns tipos de exposição, como, por exemplo, mesas interativas ${ }^{322}$.

\footnotetext{
${ }^{318}$ HOWARTH, JR.; MEDRANO, 1997, p. 12.

${ }^{319}$ ANDERSON, 1991, p. 78-84.

${ }^{320}$ Ibidem, p. 86.

${ }^{321}$ Ibidem, p. 48.

${ }^{322}$ HOWARTH, JR.; MEDRANO, 1997, p. 7-8.
} 
As salas destinadas às exposições temporárias devem ser flexíveis para atender às necessidades variáveis das exposições que vão se sucedendo ao longo do tempo ${ }^{323}$. É conveniente localiza-las próximas à entrada, de forma a que o público possa acessá-las mesmo com as demais partes do centro fechadas ${ }^{324}$. Isso tem também o efeito de mostrar a instituição sempre renovada.

Anderson ${ }^{325}$ relaciona as exposições temporárias essencialmente como "fontes suplementares de renda", ainda que também tenham a função de contribuir para a variedade das exposições do museu. É interessante como o que é visto pela maioria dos autores ligados à museologia, à história e à filosofia como uma grande "blasfêmia", é abordado com naturalidade por um autor americano, que, à época em que escreveu seu livro, em 1991, era vice-presidente de programas do Museu de Ciência e Indústria de Chicago.

As áreas de circulação - quando largas o suficiente para não prejudicar a passagem dos visitantes - podem ser utilizadas para exposição de elementos planos como fotos e pinturas ${ }^{326}$ e para a acomodação de serviços complementares quando necessários. Elas devem ter dimensões suficientes para a passagem de itens de grande tamanho ${ }^{327}$, comuns nos centros de ciências, e desenho que as tornem fluidas, sem estrangulamentos ${ }^{328}$.

Os elevadores de carga, como as áreas de circulação, devem apresentar dimensões volumétricas e portas suficientes para a fácil entrada e saída de objetos de grandes dimensões. Além disso, devem apresentar fácil acesso tanto às salas de exposição quanto às oficinas e à doca de carga ${ }^{329}$.

\footnotetext{
${ }^{323}$ HOWARTH, JR.; MEDRANO, 1997, p. 15.

${ }^{324}$ ANDERSON, 1991, p. 47.

${ }^{325}$ Ibidem, p. 30-31.

326 Ibidem, p. 47.

${ }^{327}$ Ibidem, p. 47.

${ }^{328}$ DANILOV, 1982, p. 142.

${ }^{329}$ HOWARTH, JR.; MEDRANO, 1997, p. 8. DANILOV, 1982, p. 142.
} 
Muitas exposições são extraordinariamente pesadas, necessitando de um dimensionamento estrutural muito mais robusto do que o de um edifício de escritórios. Isso deve ser levado em conta para todos os espaços que vão eventualmente recebê-las: os elevadores de carga, as áreas de circulação de serviço e as áreas de exposição ${ }^{330}$.

Para evitar que haja fila nos sanitários ${ }^{331}$, Anderson sugere que se disponibilizem mais vasos e lavatórios para as mulheres do que para os homens, que se coloquem sanitários adicionais nos locais onde se restringe o acesso (chegada de ônibus ou locais de apresentações com horário de entrada), que se evite a utilização de secadores elétricos de mãos (porque eles aumentam o tempo de permanência das pessoas no sanitário) e vasos com caixa de descarga (pois demoram mais para permitir a descarga subseqüente) ${ }^{332}$. Além disso, devem ser previstos locais para trocas de bebês e depósitos de material de limpeza dentro dos sanitários ou como anexos, e serem disponibilizados serviços como bebedouros e telefones públicos nas suas imediações.

Os serviços de alimentação são considerados "essenciais", sendo também a principal fonte de reclamação em um centro de ciências. A demanda maior costuma ser por lanches e serviços de auto-atendimento ${ }^{333}$. Assim como a loja, constitui-se também em uma fonte de recursos para a instituição.

Também os "Iarge screen theaters" são considerados fundamentalmente como fontes de recursos, ainda que esforços venham sendo feitos para aprimorar o seu conteúdo educacional. São as salas de projeção do tipo I max, usualmente com lotação em torno de 300 lugares $^{334}$.

\footnotetext{
${ }^{330}$ HOWARTH, JR.; MEDRANO, 1997, p. 6. DANILOV, 1982, p. 142.

${ }^{331}$ ANDERSON, 1991, p. 28-29.

${ }^{332}$ Ibidem, p. 45-46.

${ }^{333}$ Ibidem, p. 30-31. No original, "cafeteria”, que significa "auto-serviço”, e "very light service”, que é o equivalente ao nosso "café”, com café, refrigerante, sanduíches, doces, salgados.

${ }^{334}$ Ibidem, p. 30-31, 51-52. Podemos traduzir "large screen theaters" como "cinemas com tela de grande dimensão".
} 
Os teatros ou auditórios em centros de ciências de tamanho médio podem apresentar lotação em torno de 250 lugares. Para a situação típica de um centro de ciências - sem o uso para peças sofisticadas - os "backstages" (áreas técnicas) podem ser bastante simples ${ }^{335}$.

Áreas externas e jardins "podem ser uma importante ajuda para lidar com multidões de pico no verão" ${ }^{336}$.

Infra-estrutura técnica

Em virtude das altas taxas de energia cobradas dos grandes consumidores, uma das alternativas para os centros de ciências é a operação de geradores próprios ("sistemas de co-geração de energia"), o que, entretanto, exige serviços especializados e pessoal treinado ${ }^{337}$.

A maioria dos museus pesquisados por Howarth, Jr. e Medrano utiliza um sistema flexível de pontos de elétrica, normalmente uma grelha no piso e/ou no forro, a cada três metros ${ }^{338}$. No que se refere ao abastecimento de água, gás e ar comprimido, apresentaram duas estratégias possíveis: suprir apenas os locais das exposições iniciais que necessitem deles ou executar um sistema flexível que possa acomodar alterações posteriores ${ }^{339}$.

Outra necessidade fundamental é a existência de um sistema de prevenção, detecção e combate aos incêndios, evitando pôr vidas em perigo e sofrer danos materiais. O sistema de detecção é indispensável, pois a maioria dos incêndios se inicia em locais onde não há a presença constante de pessoas que possam dar o

\footnotetext{
335 ANDERSON, 1991, p. 51-52.

${ }^{336}$ Ibidem, p. 53.

${ }^{337}$ Ibidem, p. 88.

${ }^{338}$ HOWARTH, JR.; MEDRANO, 1997, p. 10-11.

339 Ibidem, p. 11.
} 
alarme. O plano de ação contra incêndios deve incluir procedimentos de evacuação e combate ao fogo ${ }^{340}$.

${ }^{340}$ DANILOV, 1982, p. 152. 


\section{EXEMPLARES ESTRANGEIROS E BRASILEIROS}

6.1 Centros e museus de ciências estrangeiros

6.1.1 Cité des Sciences et de I'Industrie - Parc de la Villette, Paris, França

A Cité des Sciences et l'Industrie foi criada na época da comemoração do bicentenário da Revolução Francesa, motivo pelo qual vamos, antes de discuti-la especificamente, comentar sobre esse momento em Paris e a criação do Parc de la Villette, onde a Cité está inserida.

\section{Contexto de Paris}

O aniversário de duzentos anos da Revolução Francesa - em 1989 - foi marcado em Paris pela construção de diversos monumentos, os Grands Projets, imbuídos do "espírito da Revolução: uma tentativa de tornar a alta cultura acessível à pessoa comum" 1, por vezes buscando uma integração mais discreta, em outras se destacando em locais "cuidadosamente escolhidos" 2.

Quando Giscard d'Estaing foi derrotado por François Mitterrand, tinha já encaminhado dois dos Grands Projets: o Parc de la Villette - que incluía a Cité des Sciences et I'Industrie (com escopo definido pelo físico Maurice Lévy ${ }^{3}$ ) - e o museu do século dezenove. Mitterrand manteve ambos e adicionou outros: a reestruturação do Louvre (com a pirâmide de vidro), o Instituto do Mundo Árabe, a Opera House na Bastille, um rock concert hall em Bagnolet e uma exposição universal - os dois últimos não se concretizaram ${ }^{4}$.

Mitterrand teve que iniciar os projetos apressadamente, de forma a que uma eventual derrota nas eleições de 1986 pegasse as obras já tão adiantadas que o

\footnotetext{
${ }^{1}$ DAVEY, 1989, p. 27.

${ }^{2}$ Ibidem, p. 29.

${ }^{3}$ CITÉ, 2010.

${ }^{4}$ DAVEY, 1989, p. 28.
} 
governo subseqüente não teria como paralisá-las ${ }^{5}$ - um problema, aparentemente, comum no mundo todo...

Davey considera a maioria dos Grands Projets "vazios de significado e de relação criativa com o uso humano" ${ }^{6}$.

Parc de la Villette. Paris

Foi organizado em 1982 o concurso para o Parc de la Villette, com o objetivo de vir a ser um parque modelo para o século $21^{7}$, "marcar a visão de uma era" e revitalizar $^{8}$ e "desenvolver uma área importante de Paris" 9 . Segundo Tschumi, esse modelo seria o do "parque urbano", um novo programa ${ }^{10}$. Sob esse aspecto, a idéia poderia ser questionada a partir de Argan (ver Capítulo 5, tópico 5.2): criar intencionalmente um novo tipo não seria possível; ao passo que criar um modelo repetível não seria desejável.

O local era uma das últimas grandes áreas disponíveis em Paris, com aproximadamente quinhentos mil metros quadrados em um terreno com mil metros de comprimento e setecentos metros de largura ${ }^{11}$. A área era permeada por edifícios industriais e rodeada por bairros de trabalhadores imigrantes ${ }^{12}$. 0 assentamento de La Villette é mencionado pela primeira vez em $1198^{13}$.

O concurso determinava que se considerasse o projeto anterior do edifício da Cité des Sciences et I'Industrie (concurso de 1980), assim como a Cidade da Música, o Grand Halle (para exibições), e o rock concert hall ${ }^{14}$ :

\footnotetext{
${ }^{5}$ DAVEY, 1989, p. 28.

${ }^{6}$ Ibidem, p. 29.

${ }^{7}$ MONTANER, 2001a, p. 236; GARCIAS, 1989, p. 159.

${ }^{8}$ TSCHUMI, 2000, p. 12.

${ }^{9}$ Ibidem, p. 53.

${ }^{10}$ Ibidem, p. 55.

${ }^{11}$ Ibidem, p. 53.

${ }^{12}$ MONTANER, 2001a, p. 236.

${ }^{13}$ CITÉ, 2010.

${ }^{14}$ TSCHUMI, 2000, p. 53.
} 
O objeto do concurso era selecionar um arquiteto chefe que coordenasse o master plan e também construísse os elementos estruturantes do parque. Artistas, arquitetos paisagistas, e outros arquitetos deveriam contribuir com uma variedade de jardins e edifícios ${ }^{15}$.

A Cidade da Música, por exemplo, foi projetada por Christian de Portzamparc.

De um grupo inicial de 470 candidatos, nove foram selecionados para a (nãoprevista) segunda fase, entre eles Rem Koolhaas e Bernard Tschumi, cujos projetos se destacavam como propostas menos bucólicas e mais programáticas ${ }^{16}$.

Tschumi acabou se sagrando o vencedor. A partir de sua inserção no grupo de arquitetos da nova abstração formal, projetou o La Villette como

um novo universo autônomo baseado nas leis da geometria, a partir da superposição de três tipos de tramas formais: pontos (convertidos em follies de cor vermelha, forma cúbica, expressividade neoconstrutivista e diferentes usos possíveis), linhas (um continuum de corredores lineares e curvos que ao se sobrepor e cruzar cria pontos de tensão formal) e superfícies (uma série de plataformas verdes e volumes de diversos usos culturais e lúdicos) ${ }^{17}$.

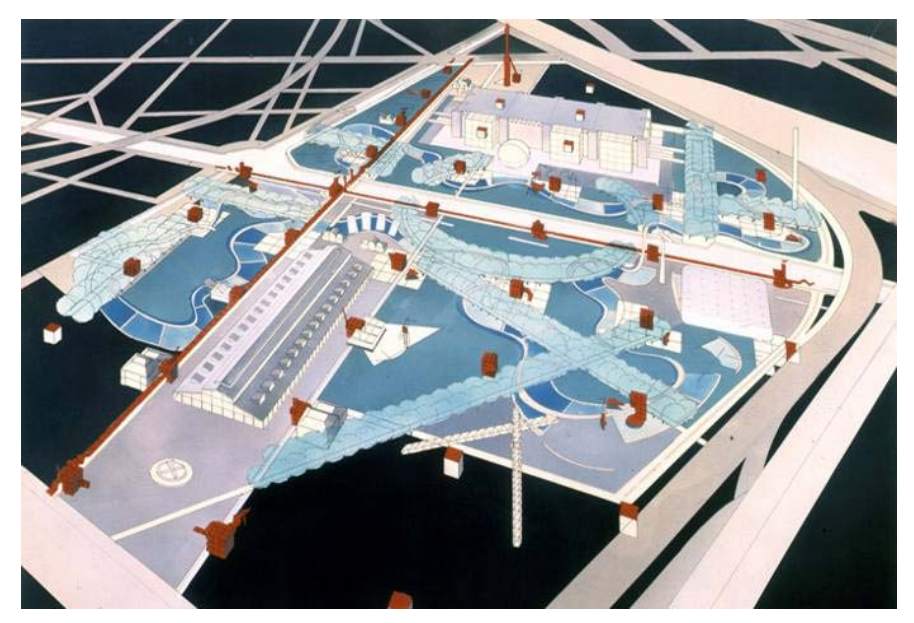

Fig. 03. Parc de la Villette. Projeto de Bernard Tschumi. Na parte superior pode-se ver o edifício da Cité e a Géode (projetos de Fainsilber). Homepage de Tschumi, 2010.

\footnotetext{
15 TSCHUMI, 2000, p. 53. Tradução nossa.

${ }^{16}$ LORIERS, 1983, p. 26.

${ }^{17}$ MONTANER, 2001a, p. 236.
} 
Montaner, entretanto, questiona a recriação das tensões metropolitanas no interior de um parque popular ${ }^{18}$. E Balmori - arquiteta paisagista - afirma que falta integração entre a arquitetura e o paisagismo no La Villette ${ }^{19}$. Ela lamenta a supremacia da arquitetura sobre a natureza no La Villette, entendendo que, já que a natureza está cada vez mais ausente da cidade, ao menos num parque ela deveria ter presença marcante, como um ato de resistência ${ }^{20}$. Se essa consideração foi feita em 1989, atualmente as preocupações ecológicas a tornam ainda mais pertinente.

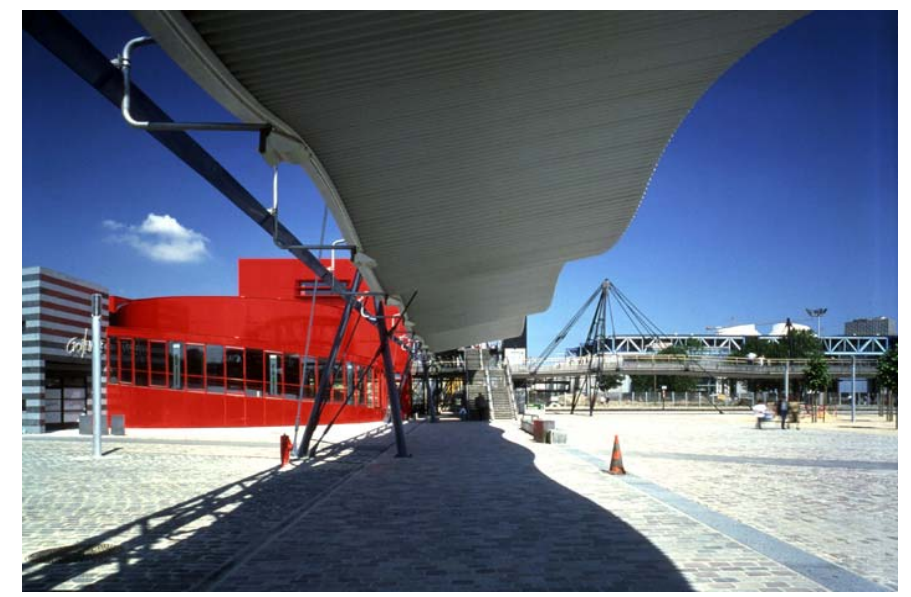

Fig. 04. Parc de la Villette. Uma das follies, à esquerda. Bernard Tschumi. Homepage do arquiteto, 2010.

Outra crítica vem de Jones. Ele vê incoerência no discurso de Tschumi, que enfatiza somente as colisões e disjunções do La Villette, ignorando o tanto de ordem que existe no parque, representada pelos dois eixos principais - "quase decumanus e cardo" -, pela malha ortogonal e pelas follies cúbicas, com modulação de $120 \mathrm{~m}$ e $10 \mathrm{~m}$, respectivamente. ${ }^{21}$

O resultado final, após as contribuições de diversos arquitetos, foi, segundo Montaner, desvirtuado, convertendo o La Villette num "mostruário de diversas propostas formais" 22 .

\section{Cité des Sciences et de I'Industrie}

\footnotetext{
${ }^{18}$ MONTANER, 2001a, p. 236.

${ }^{19}$ BALMORI, 1989, p. 37.

${ }^{20}$ Ibidem, p. 36.

21 JONES, 1989.

${ }^{22}$ MONTANER, 2001a, p. 238.
} 
Introdução. Origens e contexto histórico. Localização.

Em 1867 Haussman determinou que em La Villette se concentrassem os matadouros e o mercado de carne de Paris. A partir dos anos 1950 considerou-se que as estruturas estavam ultrapassadas e necessitavam ser modernizadas. Investiram-se grandes recursos para tornar os matadouros de Paris os mais modernos do mundo, iniciando-se nos anos 1960 a construção de um edifício para ser um enorme mercado de carne - entretanto, com a criação dos caminhões frigoríficos, os matadouros passaram a se localizar próximos aos locais de criação, tornando a sua existência em centros urbanos desnecessária. Em 1974 eles foram totalmente desativados no La Villette ${ }^{23}$. Banham também cita esse grande erro de se pensar em criar um moderno matadouro, quando a própria idéia de matadouro numa região metropolitana já não podia ser moderna ${ }^{24}$.

Em 1980 houve um concurso para transformar o edifício do mercado de carne em um museu de ciência e tecnologia, que incluía também “um novo parque público com alamedas arborizadas". Adrien Fainsilber foi o ganhador e veio a se tornar o autor do projeto arquitetônico e paisagístico do Cité des Sciences et de I'Industrie. Mas a parte do parque ${ }^{25}$ foi engavetada e novo concurso foi organizado, cujo resultado saiu em 1983: Bernard Tschumi foi o vencedor da remodelação completa do Parc de la Villette ${ }^{26}$.

Essa nova situação "deixou Fainsilber no comando apenas da área noroeste do canal, e em conseqüência o eixo monumental que ele havia pretendido que cortasse o Cité des Sciences chega apenas até a géode" ${ }^{27}$. Segundo Banham, “o

\footnotetext{
${ }^{23}$ CITÉ, 2010; ELLIS, 1987, p. 86.

${ }^{24}$ BANHAM, 1986, p. 32.

${ }^{25}$ O parque de Fainsilber seria “essencialmente Beaux-Arts”, nas palavras de BANHAM, 1986, p. 33.

${ }^{26}$ ELLIS, 1987, p. 86; BANHAM, 1986, p. 33.

${ }^{27}$ BANHAM, 1986, p. 32-33. Tradução nossa.
} 
edifício deve ser agora considerado mais ou menos em isolamento, como um objeto solto" 28 .

Segundo Banham, a Cité foi o "único dos Grands Projets remanescentes de sua geração que saiu da onda [...] de restrições financeiras mais ou menos completo" 29.

A Cité é tipicamente um science center, da terceira geração de museus de ciência ${ }^{30}$, com três milhões de visitantes anuais ${ }^{31}$.

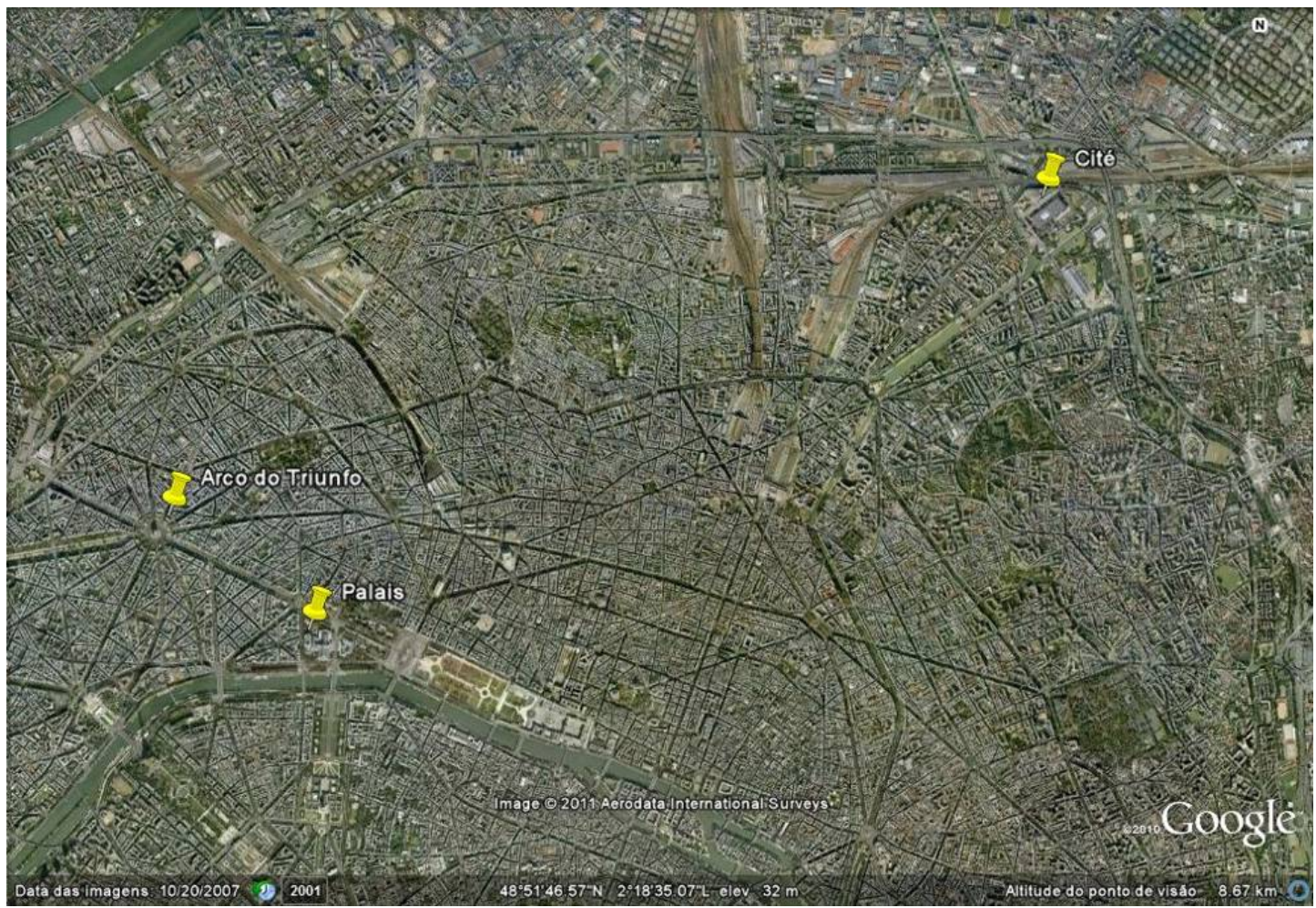

Fig. 05. Malha urbana de Paris, mostrando a posição central do Palais de la Découverte e a Cité relativamente afastada, a cerca de sete quilômetros do Arco do Triunfo. Google, 2007.

Quando a Cité foi inaugurada em 1986 faltava muito para estar de fato terminada. Um ano após ainda havia pelo menos um quarto das áreas de exposição permanente vazias. A inauguração se deu por imposição de François Mitterrand enquanto ainda tinha maioria no Parlamento - as eleições se deram poucas horas

\footnotetext{
${ }^{28}$ BANHAM, 1986, p. 32-33. Tradução nossa.

${ }^{29}$ Ibidem, p. 33.

${ }^{30}$ GIL, 1988, p. 82.

${ }^{31}$ CITÉ, 2010.
} 
depois da abertura em 13 de março. Segundo Ellis, a decisão, entretanto, se mostrou bem-sucedida, pois o edifício se tornou uma espécie de exposição em si mesmo enquanto estava sendo finalizado, e "era difícil não voltar, de novo e mais uma vez, para ver o que havia mudado" ${ }^{32}$.

Em dezembro de 2007 o governo francês decidiu juntar o Palais de la Decouvérte e o Cité em uma mesma instituição, o Universcience. ${ }^{33}$

O Palais teve origem na Exposição Universal de 1937 em Paris, e foi posteriormente integrado à Universidade de Paris. Quem concebeu e promoveu o Palais foi Jean Pérrin, com objetivo de desmistificar a Ciência, divulgar os "fundamentos básicos das Ciências Exatas e, sobretudo, atrair a atenção dos jovens para a prática científica" ${ }^{34}$. Em vista desses objetivos, Gil vê no Palais um embrião dos science centers americanos ${ }^{35}$, fazendo parte da segunda geração de museus de ciências ${ }^{36}$. Além disso, o Palais já apresentava exibições interativas e demonstrações ao vivo de princípios científicos ${ }^{37}$. Atualmente tem área de exposições de $2.000 \mathrm{~m}^{2}$ e média de visitação de 500 mil visitantes por ano, dos quais cerca de $20 \%$ são escolares, com o restante sendo prioritariamente de famílias ${ }^{38}$. A visitação média anual da Cité, por outro lado, é superior a três milhões de pessoas ${ }^{39}$. Se compararmos ambos os museus, o Palais tem visitação por metro quadrado muito superior à da Cité.

O edifício.

É essencialmente um paralelepípedo cuja lateral maior mede $270 \mathrm{~m}$, e apresenta 165 mil metros quadrados construídos, ao lado do qual se encontra uma grande

\footnotetext{
${ }^{32}$ ELLIS, 1987, p. 85. Tradução nossa.

${ }^{33}$ CITÉ, 2010.

${ }^{34}$ GIL, 1988, p. 80.

${ }^{35}$ Ibidem, p. 80.

${ }^{36}$ Ibidem, p. 82.

${ }^{37}$ GASPAR, 1993, Capítulo IV - Item 3.2 - Objetos e experimentos - formas de expor e apresentar;

DANILOV, 1982, p. 249-250.

${ }^{38}$ BLACHE, 2006, p. 2.

${ }^{39}$ CITÉ, 2010.
} 
esfera de cerca de 36 m de diâmetro. “É a maior estrutura de divulgação científica do mundo", com 30 mil metros quadrados de exposição permanente e 10 mil metros quadrados de exposição temporária. Existem exposições relacionadas a empresas industriais; planetário; centro de documentação multimídia; centro de conferências; a maior sala de projeção hemisférica do mundo, a "Géode", com a “utilização maciça dos mais modernos meios audiovisuais e computacionais de comunicação" ${ }^{40}$. Com o objetivo de atrair um público diversificado, "criou em seu interior, em 1992, a Cidade das Crianças, com 3.800 metros quadrados dedicados a crianças entre 3 e 12 anos" $^{41}$.

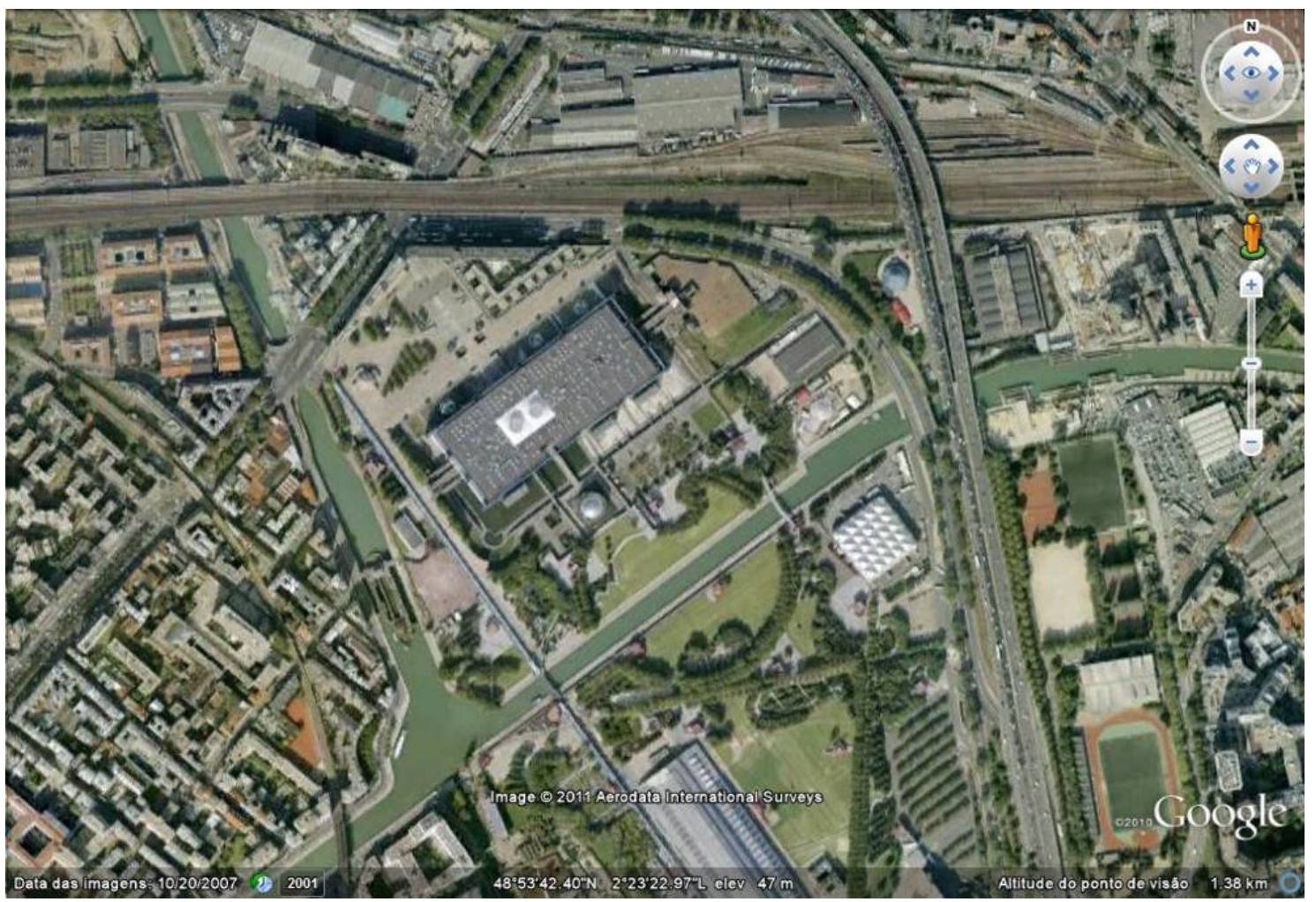

Fig. 05. Cité e o La Villette. Foto aérea. Google, 2007.

A Géode - o cinema com maior visitação na França - foi inaugurada quase um ano antes da Cité, em seis de maio de $1985^{42}$. Fainsilber dá especial atenção a ela: uma esfera lisa e brilhante, que reflete tanto o céu quanto a água do espelho d'água

\footnotetext{
${ }^{40}$ GIL, 1988, p. 82.

${ }^{41}$ MONTANER, 1995, p. 126. Tradução nossa.

${ }^{42}$ CITÉ, 2010.
} 
adjacente. Localiza-se ao lado da entrada do edifício principal. O autor justifica a escolha formal relacionando a Géode a um "acontecimento arquitetônico", uma oportunidade única de desenvolver o tema arquitetônico da esfera que anteriormente só existiu no papel ${ }^{43}$ - que discutiremos no Capítulo 7.

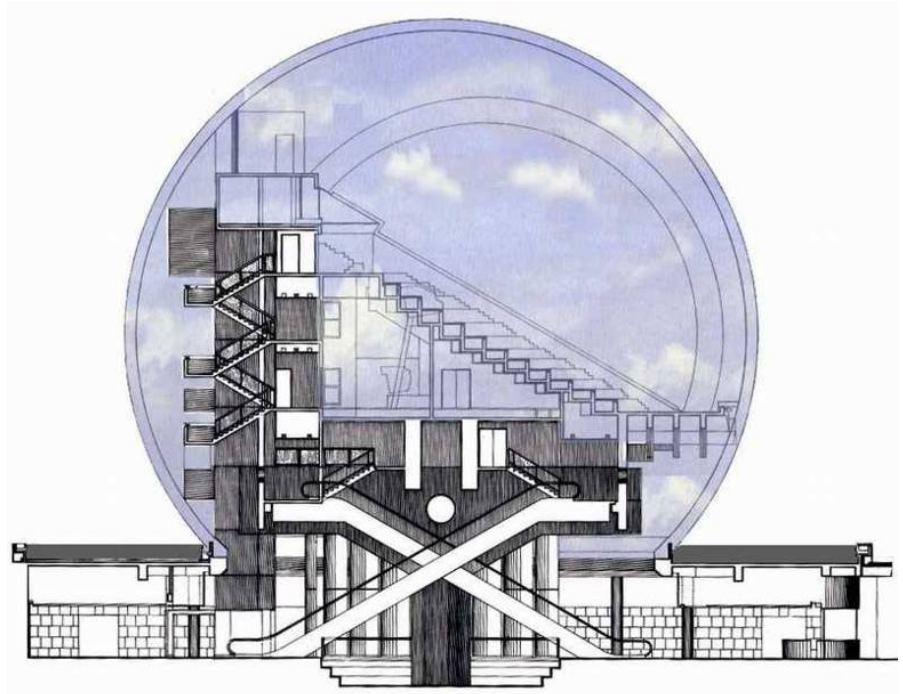

Fig. 07. Géode. Corte. Adrien Fainsilber. Homepage do arquiteto, 2010.

Como não se considerava que o matadouro tivesse relevância histórica ou arquitetônica, Fainsilber teve ampla liberdade para modificar o edifício préexistente ${ }^{44}$. Seu projeto consiste essencialmente em cavar um poço ${ }^{45}$ ao redor das fundações pré-existentes, aumentando a altura aparente do edifício e possibilitando que ele se acomode em um espelho d'água ${ }^{46}$. Segundo Ellis, ele conseguiu atingir uma coerência geral pelo seu uso de acabamentos e formas geométricas simples ${ }^{47}$.

Fainsilber pretendia incluir coletores solares na fachada sul na forma de grandes naves envidraçadas - como estufas-, que funcionariam como um sistema de condicionamento de ar. Entretanto, a idéia foi descartada em favor do sistema convencional, sendo preservada apenas como elemento arquitetural, e não na

\footnotetext{
${ }^{43}$ FAINSILBER, 2010.

${ }^{44}$ ELLIS, 1987, p. 86.

${ }^{45}$ No original, "moat”.

${ }^{46}$ No original, "shallow lake".

${ }^{47}$ ELLIS, 1987, p. 86.
} 
fachada sul, mas no foyer principal. A inclusão tardia do condicionamento de ar resultou em uma colocação meio "errática" de dutos no edifício ${ }^{48}$.

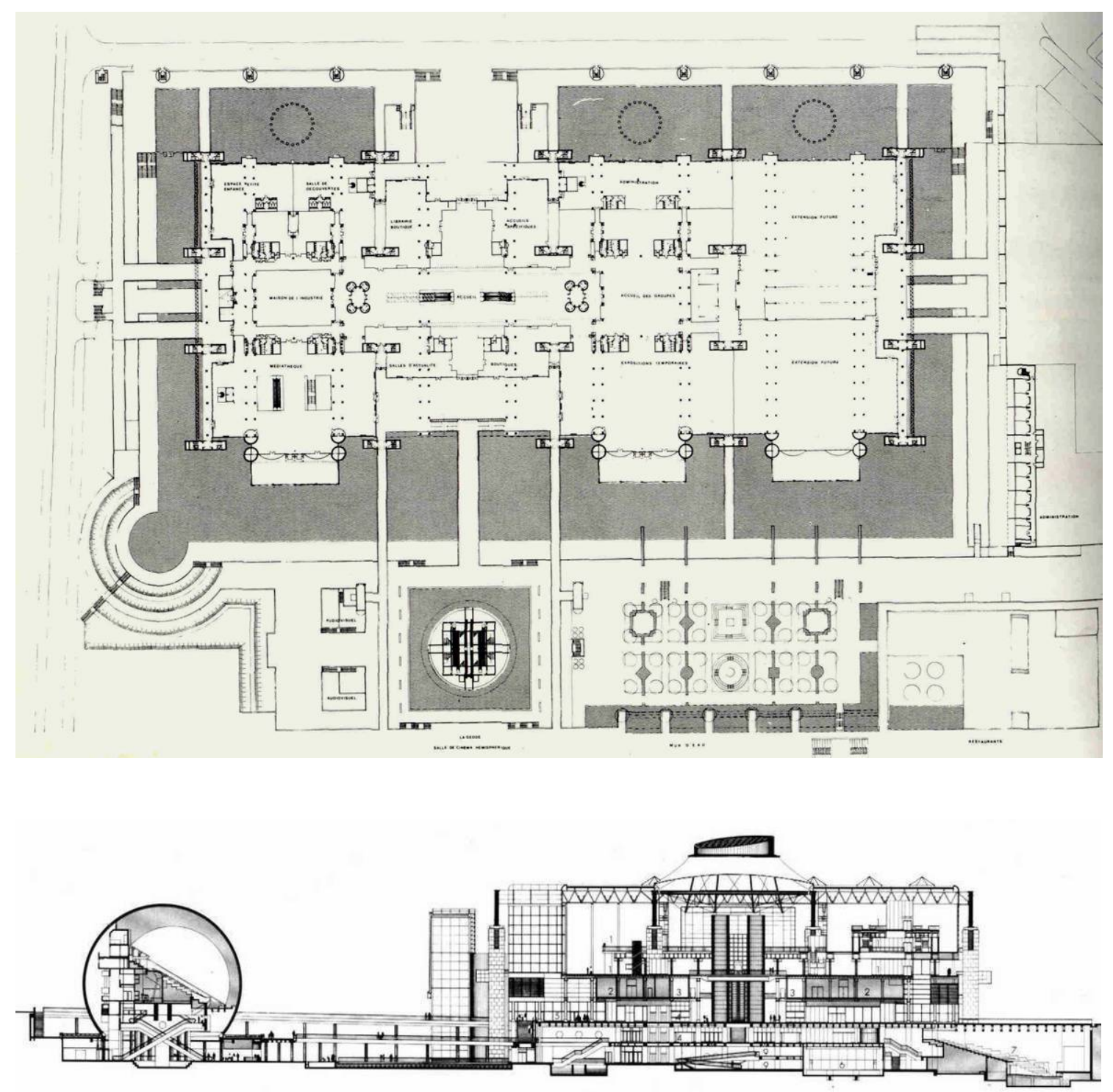

Fig. 08.

Acima - Planta térreo. The Architectural Review, v. 180, n. 1078, p. 32.

Abaixo - Corte transversal. Adrien Fainsilber. Homepage do arquiteto, 2010.

Segundo Dutton, que trabalhou com Rice no projeto das fachadas de vidro estrutural da Cité, este foi “um dos primeiros projetos a usar o vidro em sua plena capacidade estrutural" ${ }^{49}$. Cada pano de vidro é composto por 16 peças de $2 \mathrm{~m} \times 2$ $\mathrm{m}$, totalizando um quadrado de $8 \mathrm{~m}$ de lado.

\footnotetext{
${ }^{48}$ ELLIS, 1987, p. 86.

${ }^{49}$ DUTTON, 2000, p. 69.
} 
O avanço estrutural do vidro em La Villette depende de três evoluções técnicas principais que o destacam do desenho tradicional de cortinas de vidro. Primeiro, a inovação do vidro reforçado industrial, que melhora sua vida útil e resistência. Em segundo lugar, o desenvolvimento da engenharia de análise não-linear possibilitando o uso de feixes de cabos curvos pré-entrelaçados. E terceiro, o desenvolvimento de uma ferragem especial para a fixação articulada das peças de vidro que permite um funcionamento previsível do vidro, ainda que ele esteja sendo fixado a um sistema de suporte relativamente flexível ${ }^{50}$.

Os feixes de cabos têm o objetivo de absorver as forças do vento, que são as únicas que o vidro não teria como absorver por si próprio ${ }^{51}$.

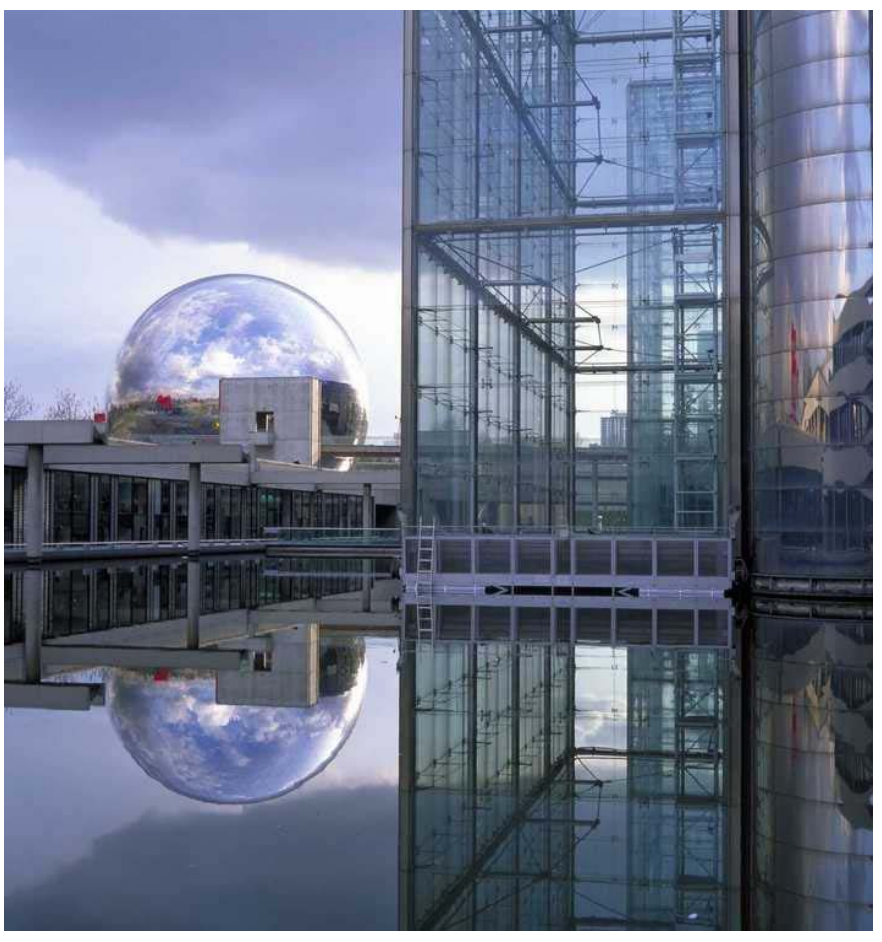

Fig. 09. Cortina de vidro em destaque, e Géode ao fundo. Adrien Fainsilber. Homepage do arquiteto, 2010.

Segundo Banham ${ }^{52}$, há um consenso geral sobre o grande sucesso da Cité e sobre o fato de ela se caracterizar como uma etapa evolutiva superior à do Centro Georges Pompidou, posição da qual ele discorda. O Pompidou teria desenho muito mais radical, como quando, por exemplo, exterioriza as circulações. A Cité seria um

\footnotetext{
${ }^{50}$ DUTTON, 2000. Tradução nossa. A ferragem citada é o chamado sistema Spider.

${ }^{51}$ Ibidem, p. 69.

${ }^{52}$ BANHAM, 1986.
} 
sucesso apenas estrutural, constituindo-se numa intervenção interna, simétrica, ortogonal e neoclássica em inspiração.

Quanto à exposição e utilização de material científico e técnico em uma disposição apropriada, pode ser mais uma consolidação do que um avanço. Visto que não foi originalmente projetado para um salão de exposição, o edifício apresenta problemas - sendo os de escala os mais óbvios [... ${ }^{53}$.

De forma geral, Banham não é favorável ao projeto. Considera-o convencional, sem grandes avanços - ele apenas parece avançado, mas não o seria conceitualmente. Seu problema de escala se dá tanto nas fachadas quanto no espaço interno: ele é grande demais, e não há nenhum recurso declarado para compensar essa excessiva monumentalidade. As exposições tendem a encolher insignificantes em relação ao espaço interior ${ }^{54}$. Essa preocupação ocorre também a um não-arquiteto. Gil apresenta a seguinte questão: “Não acontecerá que a espantosa espetacularidade dos ambientes criados na 'Cité' não desvie a atenção do visitante da observação do pormenor e da reflexão sobre o que observa $[\ldots]$ ?" $^{55}$.

Por outro lado, ainda que Banham não comente, o destaque visual dos grandes pilares aparentes nas fachadas faz com que a principal, por exemplo, seja dividida em quatro partes, diminuindo o efeito de monumentalidade.

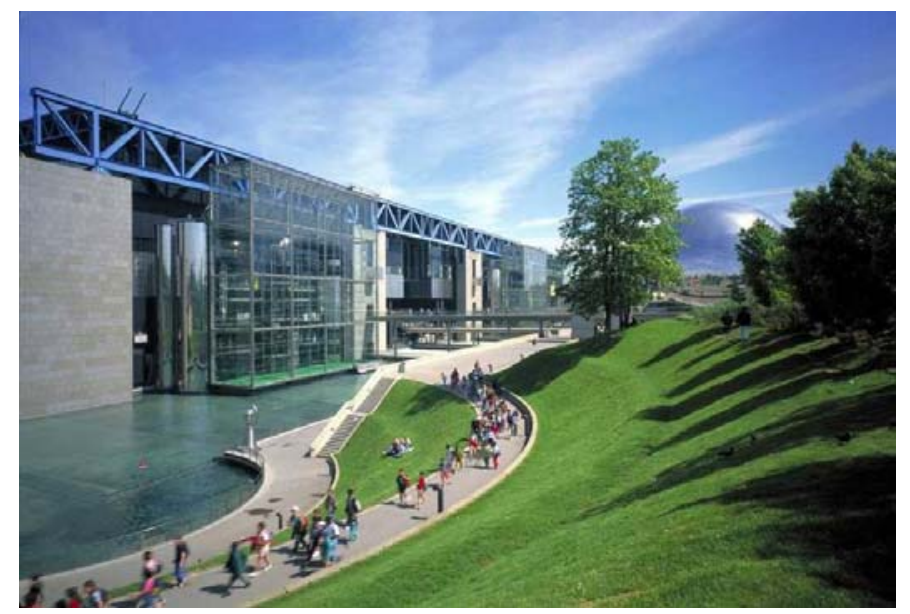

Fig. 10. Fachada sudeste, e Géode ao fundo. Adrien Fainsilber. Homepage do arquiteto, 2010.

\footnotetext{
${ }^{53}$ BANHAM, 1986, p. 32. Tradução nossa.

${ }^{54}$ Ibidem. A Cité é três vezes maior que o Pompidou.

${ }^{55}$ GIL, 1999, p. 82.
} 
As duas clarabóias mecanizadas para o controle de luz, especialmente desenhadas para o edifício, também não agradaram a Banham. “[...] a estrutura é visualmente muito similar a uma teia, e os elementos refletivos muito pequenos para combinar com a vastidão do espaço abaixo $[\ldots]{ }^{\prime 56}$. O mesmo se dá com as estruturas das "estufas".

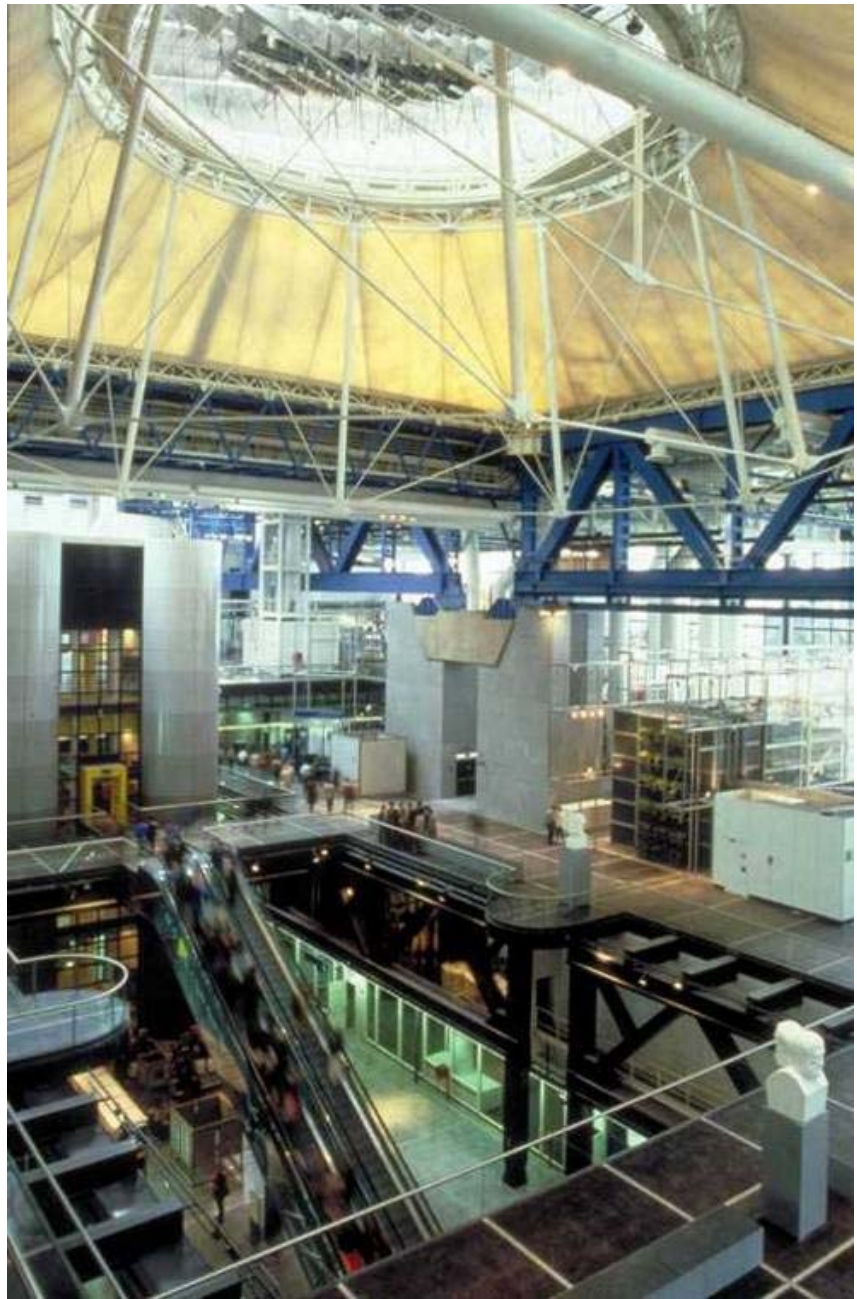

Fig. 11. Lobby e óculo. Adrien Fainsilber. Homepage do arquiteto, 2010.

Existe um pavimento intermediário de serviços - ambientais, de manutenção e de informática -, “que o público nunca verá, [e que seria] a mais instrutiva exposição de ciência e tecnologia em todo o prédio" ${ }^{57}$. Ainda que esse comentário nos remeta às estratégias de outros arquitetos, de mostrar oficinas e áreas técnicas (Renzo

\footnotetext{
${ }^{56}$ BANHAM, 1986, p. 36. Tradução nossa.

${ }^{57}$ Ibidem, p. 36. Tradução nossa.
} 
Piano no Nemo58; Álvaro Siza no Museu Iberê Camargo) - que são em muitas ocasiões interessantes - talvez Banham tenha se deixado levar por uma visão romantizada da tecnologia: será que uma sala de computadores teria realmente algo a oferecer aos visitantes?

Entretanto, há alguns elogios, como com relação ao lobby, "bem-sucedido" e excitante; e com relação aos dutos de condicionamento de ar, que estariam "entre os mais espetaculares elementos do edifício". Ou quando afirma que a solução de Fainsilber demonstra grande habilidade arquitetônica - ainda que uma habilidade convencional ${ }^{59}$.

${ }^{58}$ BUCHANAN, 2000, p. 41.

${ }^{59}$ BANHAM, 1986. 


\subsubsection{California Academy of Sciences, São Francisco, EUA}

Introdução. Origens. Contexto histórico. Localização.

A Academia de Ciências da Califórnia (California Academy of Sciences) não é um centro de ciências típico, o qual costuma concentrar suas atividades na divulgação científica e desenvolver pesquisas de estudo de público. É, ao contrário, um equipamento para "exibição, educação, conservação e pesquisa debaixo de um único teto" ${ }^{60}$, "um dos poucos institutos de ciências naturais onde a experiência do público está diretamente relacionada com a pesquisa científica desenvolvida pela própria instituição, no mesmo edifício" ${ }^{61}$. É definido por seu diretor executivo como um Museu de História Natural ${ }^{62}$, e possui uma coleção de pesquisa ${ }^{63}$.

Entretanto, a Academia tem desenvolvido há muitos anos com seus visitantes atividades interativas, salas de descoberta e programas especiais hands-on para os públicos escolares ${ }^{64}$. Sua nova sede, projetada por Renzo Piano e concluída em 2008, apresenta diversas características que a tornam interessante para nosso estudo.

Para a construção do novo edifício foi necessária a demolição de grande parte dos onze edifícios originais, construídos entre 1916 e 1976, no Parque Golden Gate, em São Francisco ${ }^{65}$. Isso pode ser justificado em vista da destruição causada em 1989 por um grande terremoto. “A restauração dos antigos edifícios do museu seria inviável não apenas economicamente, mas também arquitetonicamente [...]" 66 .

\footnotetext{
${ }^{60}$ RENZO, 2008, p. 24. Tradução nossa.

${ }^{61}$ Ibidem, p. 24. Tradução nossa.

${ }^{62}$ HARRINGTON, 2008, p. 343. HENNES, 2008, p. 349.

${ }^{63}$ HARRINGTON, 2008, p. 343.

${ }^{64}$ BURKE, 2008, p. 345-346; GASPAR, 1993, Capítulo IV - 3.2 - Objetos e experimentos - formas de expor e apresentar

${ }^{65}$ RENZO, 2008, p. 24.

${ }^{66}$ HORTA, 2009, p. 39.
} 
Abordagem ambiental

Enquanto no Centro George Pompidou, de 1977, “Piano explorou [...] a estética industrial com tubulações, escadas rolantes e sistema estrutural expostos [...] três décadas depois expõe na Academia uma nova ética arquitetônica balizada por estratégias ambientais" ${ }^{67}$, relacionadas à sustentabilidade ${ }^{68}$.

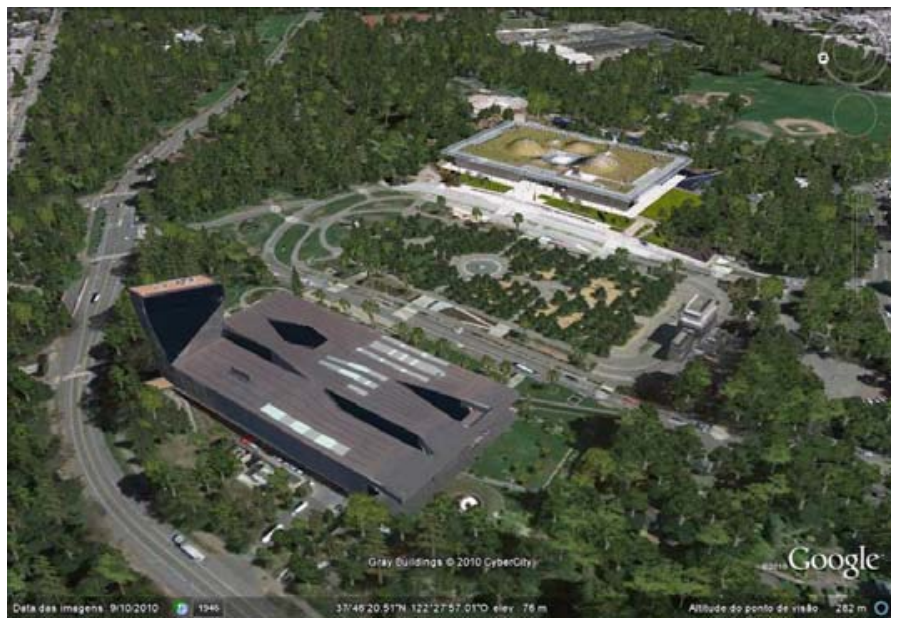

Fig. 12. Maquete eletrônica livre mostrando a implantação da Academia inserida em imenso parque. Próximo, no mesmo alinhamento, com a mesma forma e dimensão em planta, encontra-se o De Young Fine Arts Museum of San Francisco, projeto de Herzog \& de Meuron. Google, 2010.

Essas estratégias são coerentes com a missão da Academia, de "explorar, explicar e proteger o mundo natural" e com o clima de São Francisco ${ }^{69}$. Entre elas estão a eficiência energética e a geração de energia, a escolha de materiais, a adequada insolação com generosos beirais, a ventilação natural, a absorção de águas pluviais, o uso eficiente da água, a utilização de torneiras eletrônicas no banheiro cujas baterias são carregadas por microturbinas que giram com o fluxo da água ${ }^{70}$. Outras iniciativas com viés ecológico são o bicicletário, o posto de reabastecimento de veículos elétricos e a previsão de subsídios para utilização de transporte público para o staff ${ }^{71}$.

Um fator importante, também relacionado à sustentabilidade, foi a destinação dada ao grande volume de entulho gerado pelas demolições: “[...] 90\% dos escombros

\footnotetext{
${ }^{67}$ HORTA, 2009, p. 39-40.

${ }^{68}$ RENZO, 2008, p. 24.

${ }^{69}$ Ibidem, p. 24. Tradução nossa.

${ }^{70}$ Ibidem, p. 24. Tradução nossa. HORTA, 2009, p. 40 e 44.

${ }^{71}$ Ibidem, p. 25. HORTA, 2009, p. 40.
} 
foram reutilizados, 9 mil toneladas de entulho na construção de uma estrada e 12 mil toneladas de aço na estrutura do novo prédio" 72 .

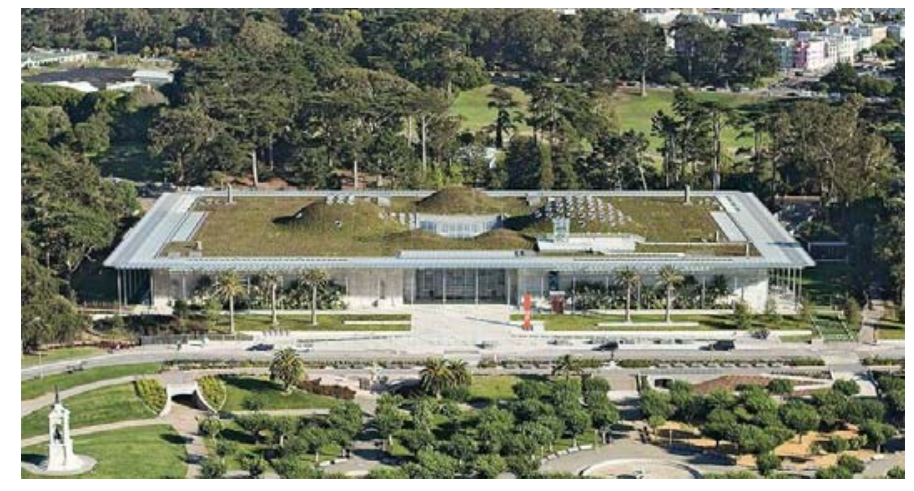

Fig. 13. Vista geral do edifício, onde pode-se observar o telhado verde e a projeção das esferas funcionais. Revista AU, 179, 2009.

A maioria dessas abordagens, entretanto, não é revolucionária e nem recente. Outras dependem dos avanços e popularização de novas tecnologias - como é o caso dos locais para reabastecimento dos veículos elétricos.

Por outro lado, uma característica bastante interessante do projeto é que Piano transformou o próprio edifício numa exposição ecológica, deixando "expostas as estratégias utilizadas como parte da expografia" ${ }^{73}$. É o caso do telhado verde, "cobertura viva" com função de isolamento térmico e absorção de águas pluviais ( $98 \%$ da chuva), com 10 mil $\mathrm{m}^{2}$ de área na qual se encontram plantadas espécies nativas que não necessitam de irrigação ${ }^{74}$. Essa cobertura "foi como que recortada e erguida $12 \mathrm{~m}$ acima do nível do terreno" ${ }^{75}$. "Todo o perímetro da cobertura foi sombreado por beirais com 60 mil células fotovoltaicas que produzem entre $5 \%$ e $10 \%$ da energia do prédio (213 mil kWh por ano)" ${ }^{76}$.

Como conseqüência dessas ações, "a Academia foi o primeiro museu a ganhar o certificado Leed Platinum do US Green Building Council, com consumo energético $35 \%$ menor do que o prescrito pelas leis da Califórnia" 77.

\footnotetext{
${ }^{72}$ HORTA, 2009, p. 44; RENZO, 2008, p. 24.

${ }^{73}$ HORTA, 2009, p. 40.

${ }^{74}$ Ibidem, p. 40; RENZO, 2008, p. 25.

${ }^{75}$ HORTA, 2009, p. 39.

${ }^{76}$ Ibidem, p. 40.

${ }^{77}$ Ibidem, p. 40-45.
} 
O edifício
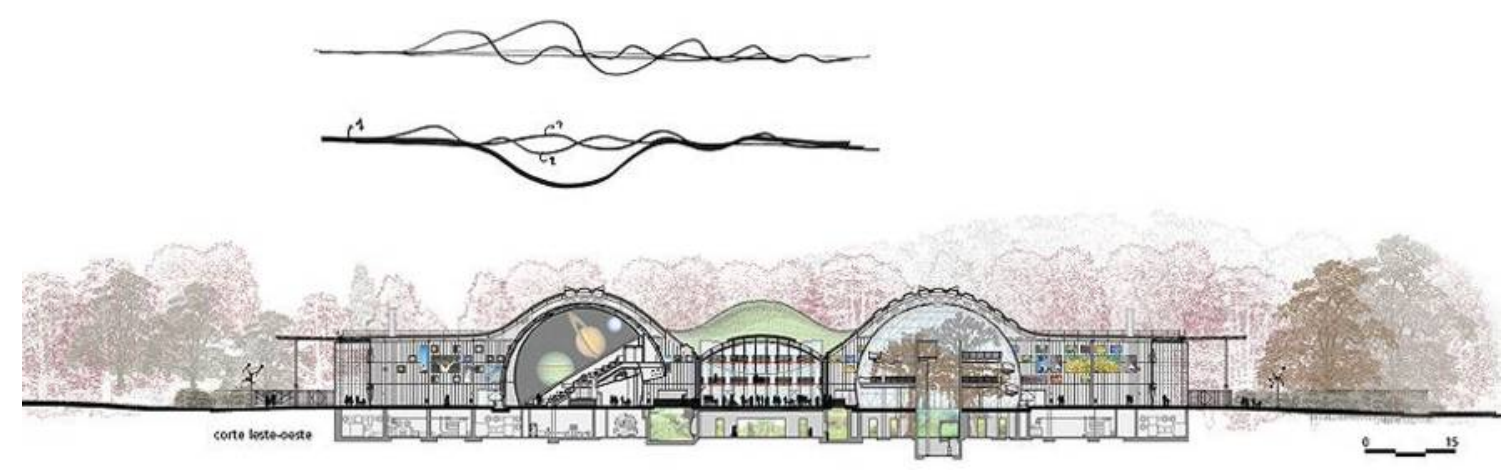

Fig. 14. Acima, croquis de Piano. Abaixo, corte. À esquerda, esfera do planetário. Ao centro, átrio. À direita, esfera dos biomas. Revista AU, 179, 2009.

A locação e a orientação do novo edifício preservam o arranjo dos edifícios originais, organizados em torno de um átrio ou praça central ${ }^{78}$, que abriga também "recepções, festas e outros eventos públicos ou privados" ${ }^{79}$. Existem dois domos de $27 \mathrm{~m}$ de diâmetro que se projetam acima da linha horizontal da cobertura: um contém o planetário e o outro os quatro ecossistemas de florestas reproduzidos (the Rainforest Dome) ${ }^{80}$. Ali se encontra uma passarela espiralada através da qual "é possível caminhar pelas copas das árvores" ${ }^{81}$. No subsolo existe um painel de acrílico que permite ver debaixo da água do ecossistema amazônico. "Junto com a entrada reconstruída do Steinhart Aquarium, esses elementos representam a Academia: Espaço, Terra e Oceano" 82.

Parece-nos que as reproduções de ecossistemas como as do Rainforest Dome se constituem na sublimação dos dioramas que se popularizaram a partir dos anos 1930, quando marcaram “o começo da afirmação da ecologia e a conseqüente imposição de uma nova temática nos museus de história natural” ${ }^{83}$.

\footnotetext{
${ }^{78}$ HORTA, 2009, p. 45; RENZO, 2008, p. 24.

${ }^{79}$ HORTA, 2009, p. 45.

${ }^{80}$ Ibidem, p. 45; RENZO, 2008, p. 24.

${ }^{81}$ HORTA, 2009, p. 45.

${ }^{82}$ Ibidem, p. 24. Tradução nossa.

${ }^{83}$ CHELINI; LOPES, 2008, p. 210.
} 


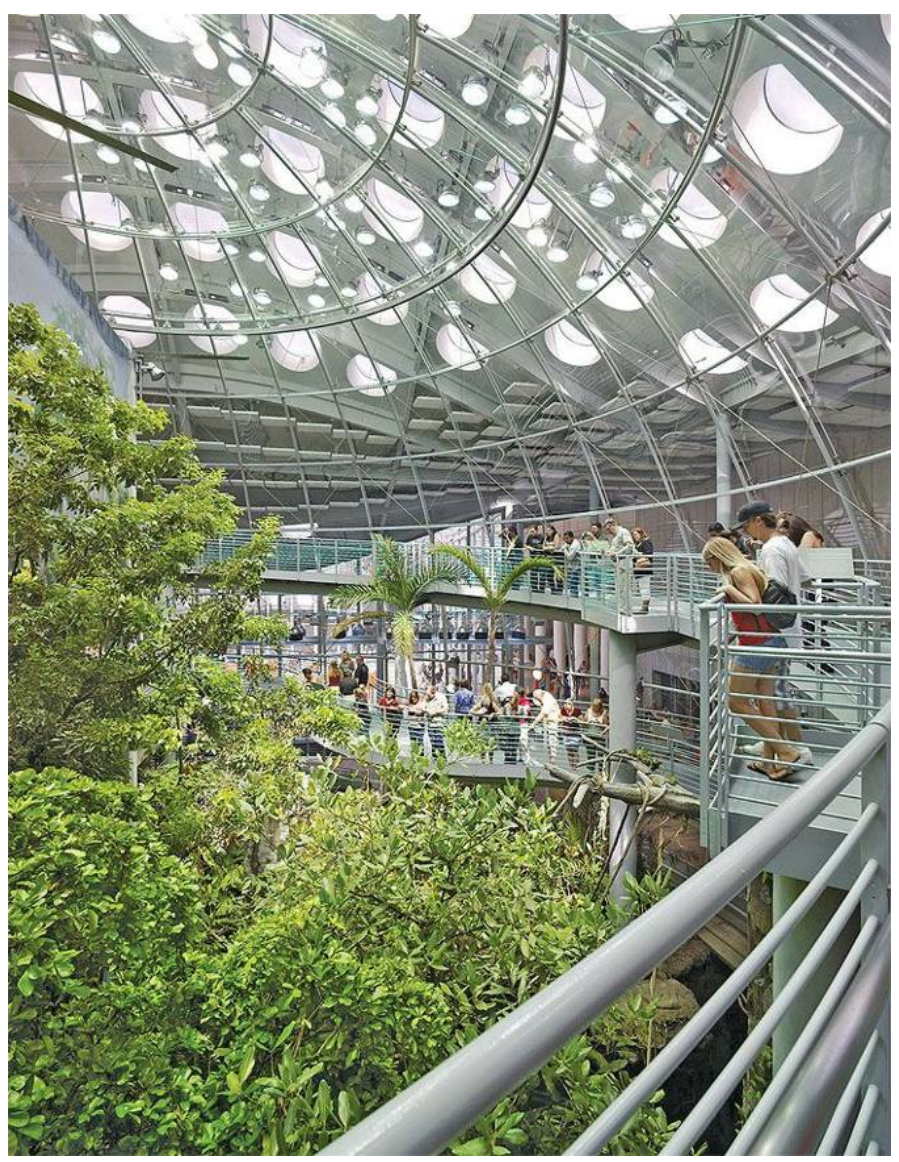

Fig. 15. Biomas. Passarelas e as copas das árvores. Revista AU, 179, 2009.

Alguns aspectos arquitetônicos devem ser ressaltados. O primeiro é o da transparência e da relação com o exterior. Piano propôs uma relação muito mais próxima com o exterior do que costumam ter os museus: “Museus são opacos, fechados. São como um reino da escuridão. Você não vê onde está. Mas aqui você está no meio de um parque lindo, então vai querer olhar para fora e saber onde está'" 84 . Além da beleza do parque - que deve ser mostrada - essa transparência e a conseqüente iluminação generosa são possíveis e apropriadas em vista do tipo de exposição, ligada à natureza. O mesmo não seria possível, na mesma medida, se o acervo fosse composto de pinturas ou documentos em papel, extremamente sensíveis à luz natural.

Outro aspecto é o da desmaterialização. Montaner relaciona o tema tanto com o museu "que mantém sua forma dentro de um contentor transparente e leve,

\footnotetext{
${ }^{84}$ HORTA, 2009, p. 45-46.
} 
quanto àquele que se escalona ou se funde no terreno" ${ }^{85}$. Na Academia encontramos as duas abordagens: o telhado verde mimetiza o edifício para o observador em "vôo de pássaro" enquanto a desmaterialização é o efeito percebido pelo pedestre, observador ao nível do solo.
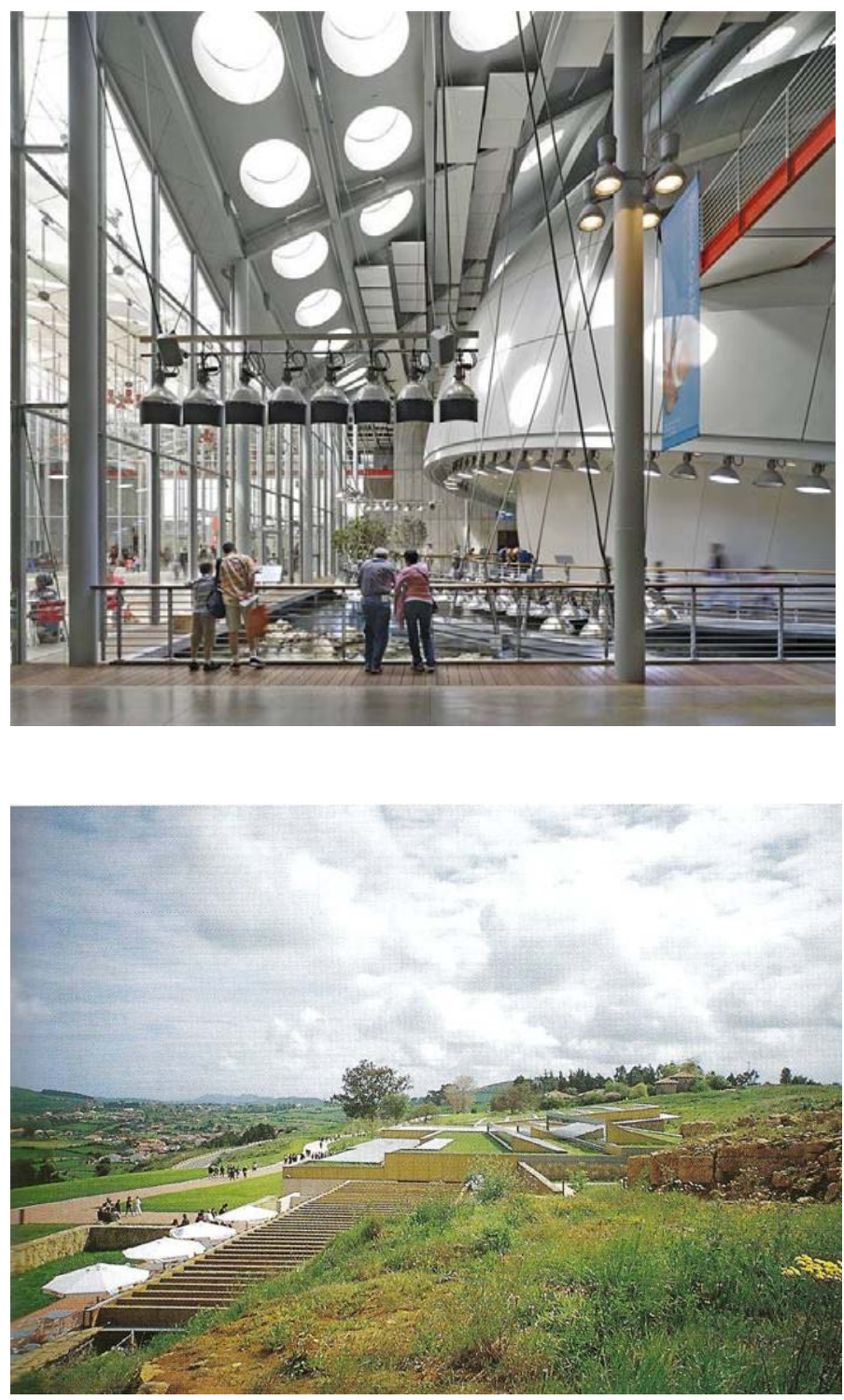

Fig. 16. Interiores com iluminação abundante. Revista AU, 179, 2009.

Fig. 17. Altamira. Desmaterialização pela fusão ao terreno. Montaner, 2003.

\section{Segundo Horta,}

a arquitetura de Piano não abriu mão de valores iluministas expressos pelo neoclassicismo, tanto em sua simetria absoluta e na repetição de colunas, ainda que de aço [...] quanto nos fragmentos de três prédios neoclássicos da

\footnotetext{
${ }^{85}$ MONTANER, 2003, p. 147.
} 
antiga academia, mantidos eretos como elemento expográfico e testemunho histórico da instituição. ${ }^{86}$

Um outro aspecto importante é a recorrência do tema da cúpula e da esfera, que será discutido mais a frente na dissertação, no capítulo 7.

${ }^{86}$ HORTA, 2009, p. 46. 


\subsubsection{Nemo / newMetropolis, Amsterdã, Holanda}

Introdução. Origem e contexto histórico.

Originalmente chamado de "newMetropolis", o Nemo é um science center localizado em Amsterdã, Holanda, com origens no Museu do Trabalho do começo do século $\mathrm{XX}$, cujo acervo consistia em máquinas e pinturas pertencentes ao seu fundador, Herman Heijenbroeck. No museu atual foram mantidas apenas algumas das pinturas $^{87}$. O edifício sede, entretanto, foi projetado por Renzo Piano a partir de 1992, com inauguração em 1997. O conjunto teve custo total de 80 milhões de florins holandeses ${ }^{88}$, o equivalente a 54 milhões de dólares.

Segundo Padilla, o Nemo seria um museu 4G ou de quarta geração (ver Capítulo 5, tópico 5.1.2), ou seja, um museu de ciência para o século XXI, onde o visitante tenha participação criativa em exibições de final aberto ${ }^{89}$. A mesma apreciação positiva não foi feita por Buchanan, que considera as exibições "caricaturas exageradas do high-tech" 90 .

Localização e inserção metropolitana

O Nemo fica no porto de Amsterdã (Oosterdok), e, em conjunto com o Maritime Museum - que fica a cerca de $600 \mathrm{~m}$ de caminhada, a sudeste -, é um grande atrativo turístico ${ }^{91}$. Seu projeto tinha a declarada intenção de favorecer a regeneração do entorno, e sua implantação teve um grande impacto sobre a malha histórica de Amsterdã ${ }^{92}$.

\footnotetext{
${ }^{87}$ BUCHANAN, 2000, p. 38.

${ }^{88}$ Ibidem, p. 45.

${ }^{89}$ PADILLA, 2001, p. 133.

${ }^{90}$ BUCHANAN, 2000, p. 45-52.

${ }^{91}$ Ibidem, p. 38.

92 Ibidem, p. 38; RENZO, 1997, p. III.
} 


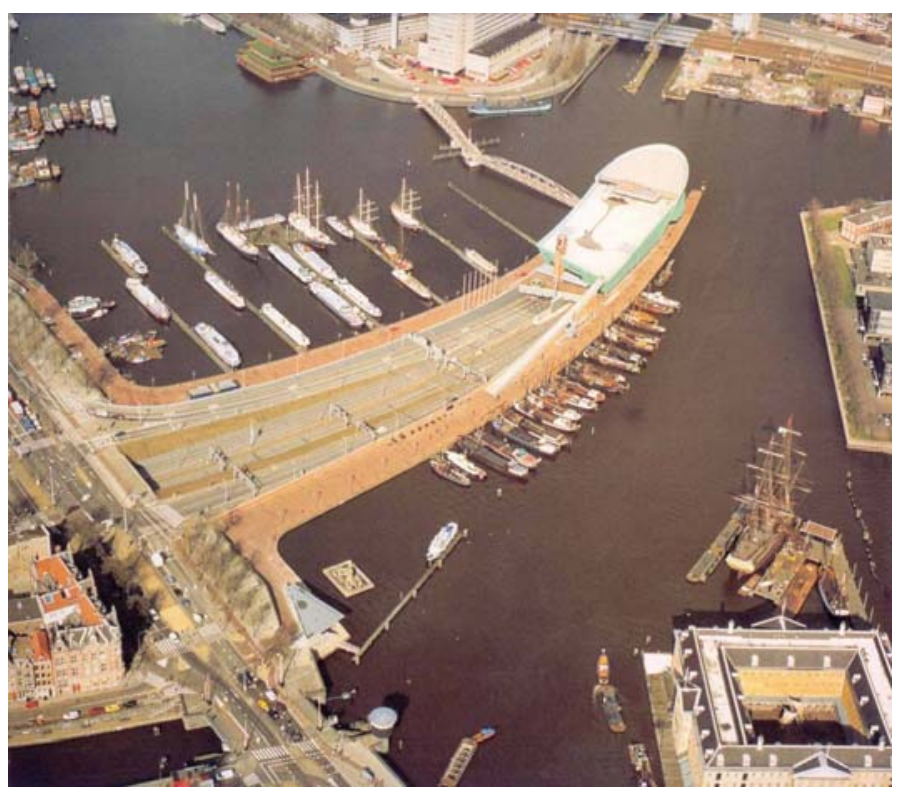

Fig. 18. Visão geral. Na parte superior central da figura, o distrito da estação de trem. Buchanan, 2000, p. 37.

A relação entre o Nemo e a cidade é muito mais complexa do que parece. O edifício dá as costas para o centro de Amsterdã e se volta para a direção do distrito em volta da estação de trem ${ }^{93}$. Segundo Piano, o edifício, mais do que pertencer à cidade, pertence às docas: “o edifício estabelece uma transição gradual da escala do centro histórico de Amsterdã para a amplidão do porto" ${ }^{94}$.

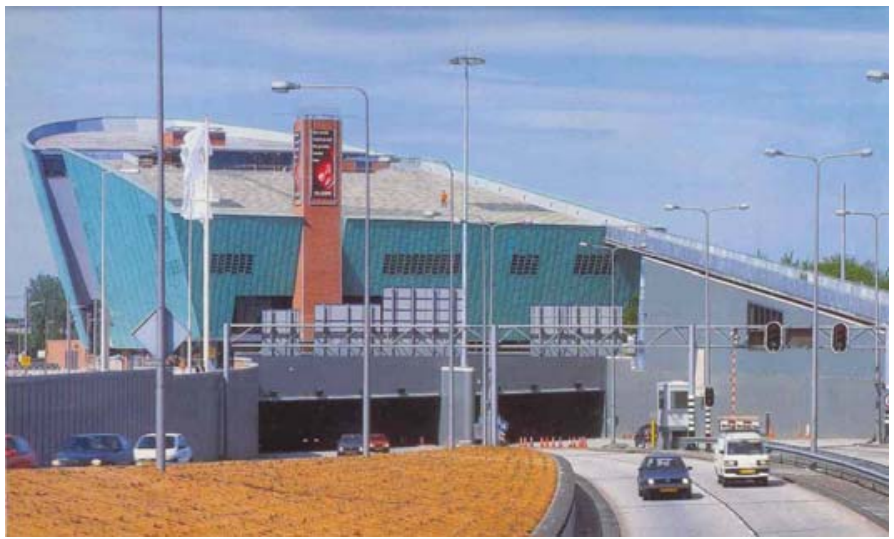

Fig. 19. Entrada do túnel, 1997. Lotus, 95, p. 21.

É relativamente difícil o acesso ao museu, pois a entrada do túnel de automóveis, que submerge na água, parece ser a entrada do edifício. Ele tem diversas entradas de pedestre: subindo a estreita rampa que dá acesso à cobertura, também inclinada, do edifício; contornando essa rampa e passando por baixo dela até o

\footnotetext{
${ }^{93}$ ROCCA, 1997, p. 12.

${ }^{94}$ RENZO, 1997, p. III. Citando Piano. Tradução nossa.
} 
acesso sobre o túnel; ou pela passarela de pedestres sobre a água. Todas são entradas pouco visíveis ${ }^{95}$. Entretanto, é possível chegar ao museu também através dos water taxis ${ }^{96}$.

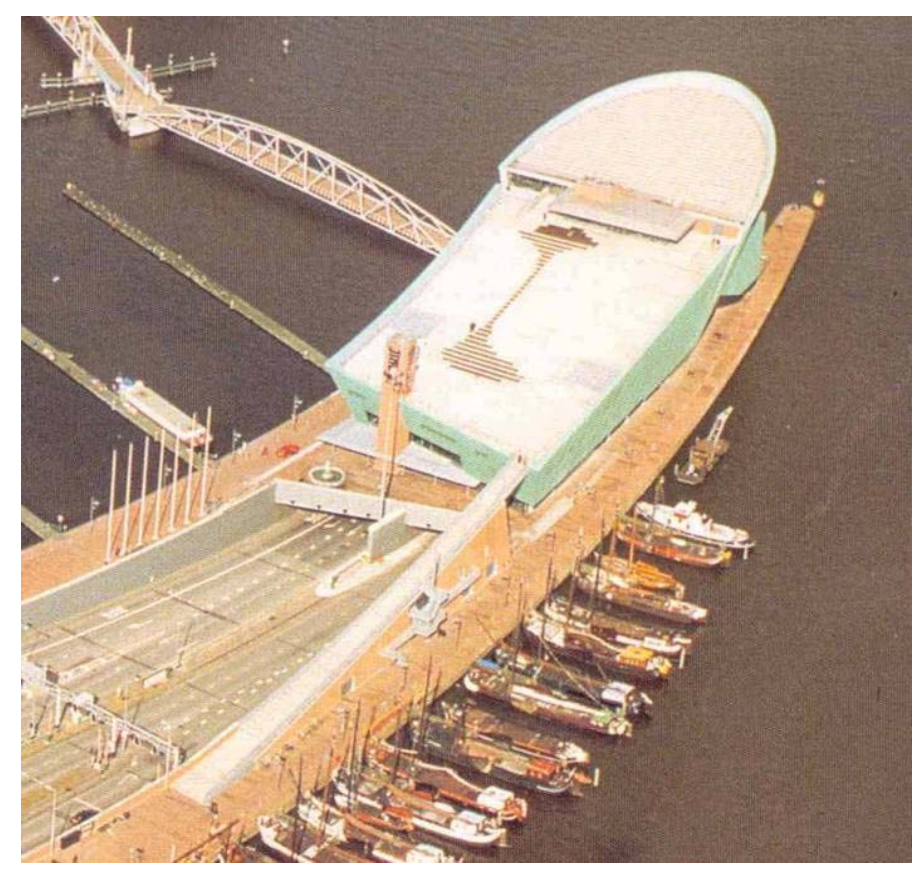

Fig. 20. Ampliação da fig. 16, onde é possível ver os acessos de pedestres: subindo a rampa até a cobertura inclinada; ou contornando-a pela direita até cruzar o vão à esquerda. Buchanan, 2000, p. 37

O edifício

Pela sua localização no porto, formando uma península, e sua forma geral, o edifício se assemelha a um navio com sua proa adentrando a água - tendo mesmo sido apelidado de Titanic ${ }^{97}$. Foi construído sobre um túnel de veículos pré-existente. Segundo Piano, o "edifício [...] não repousa, mas flutua sobre a entrada do túnel" 98.

O projeto foi elaborado como "resposta gráfica gestual ao contexto, mais do que um estudo elaborado do programa e estrutura": a rampa e a cobertura ascendentes

\footnotetext{
${ }^{95}$ ROCCA, 1997, p. 13.

${ }^{96}$ RENZO, 1997, p. III.

${ }^{97}$ BUCHANAN, 2000, p. 36.

${ }^{98}$ RENZO, 1997, p. III.
} 
formam, no desenho de seção, uma linha espelhada com a estrada descendente do túnel ${ }^{99}$.

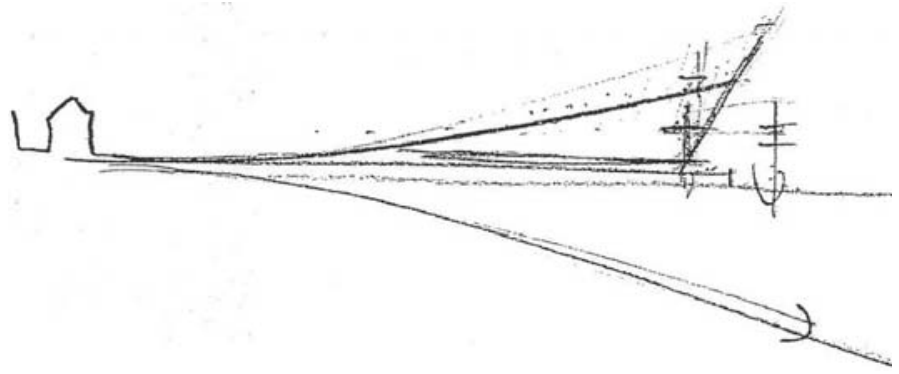

Fig. 21. Croquis de Piano, 1997. Lotus, 95, p. 9.

Segundo Buchanan, o Nemo é um marco na obra de Piano, pois "é o primeiro edifício importante no qual não há nada que possa ser convincentemente considerado $[\ldots]$ um elemento construtivo repetitivo $[\ldots]$ desenvolvido especificamente para ele e que se torne intrínseco à sua identidade" ${ }^{100}$. Ao contrário, o edifício tem uma forma unitária definida ${ }^{101}$, que claramente foi 0 elemento inicial do projeto - ainda que a seqüência espacial interna tenha grande qualidade ${ }^{102}$.

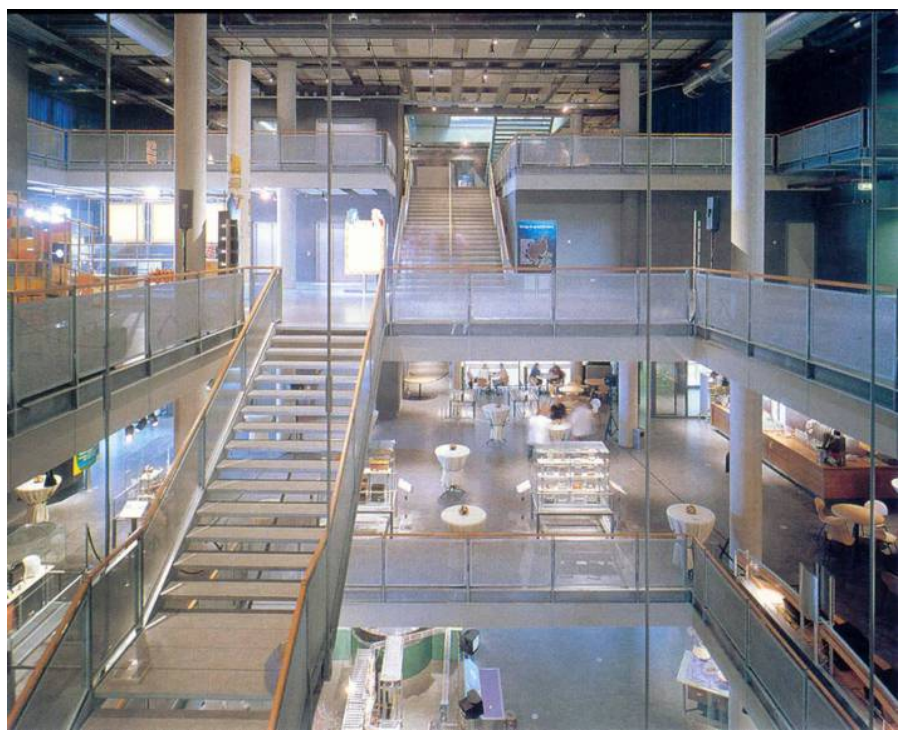

Fig. 22. Átrio. Buchanan, 2000, p. 55.

\footnotetext{
99 BUCHANAN, 2000, p. 36.

${ }^{100}$ Ibidem, p. 36. Tradução nossa.

${ }^{101}$ ROCCA, 1997, p. 13.

102 BUCHANAN, 2000, p. 36.
} 
Houve uma idéia inicial de aproveitar a totalidade das fundações do túnel. Como tinham que incluir o peso do período de construção - quando estava inundado elas não trabalham com sua capacidade total. Entretanto, somente no decorrer do processo de projeto é que foi lembrado que as fundações deveriam ser capazes de resistir na eventualidade do túnel ser novamente inundado. Em vista disso, abandonou-se a idéia. Como se vê, o Nemo utiliza a tecnologia que a Holanda domina e da qual depende: a engenharia civil relacionada com a água ${ }^{103}$. A maior parte do edifício tem estrutura de concreto, "estabilizado" por quatro torres de serviço, mas a "proa" tem estrutura de aço, com lajes metálicas suportadas por uma "gaiola periférica de aço" ${ }^{104}$.

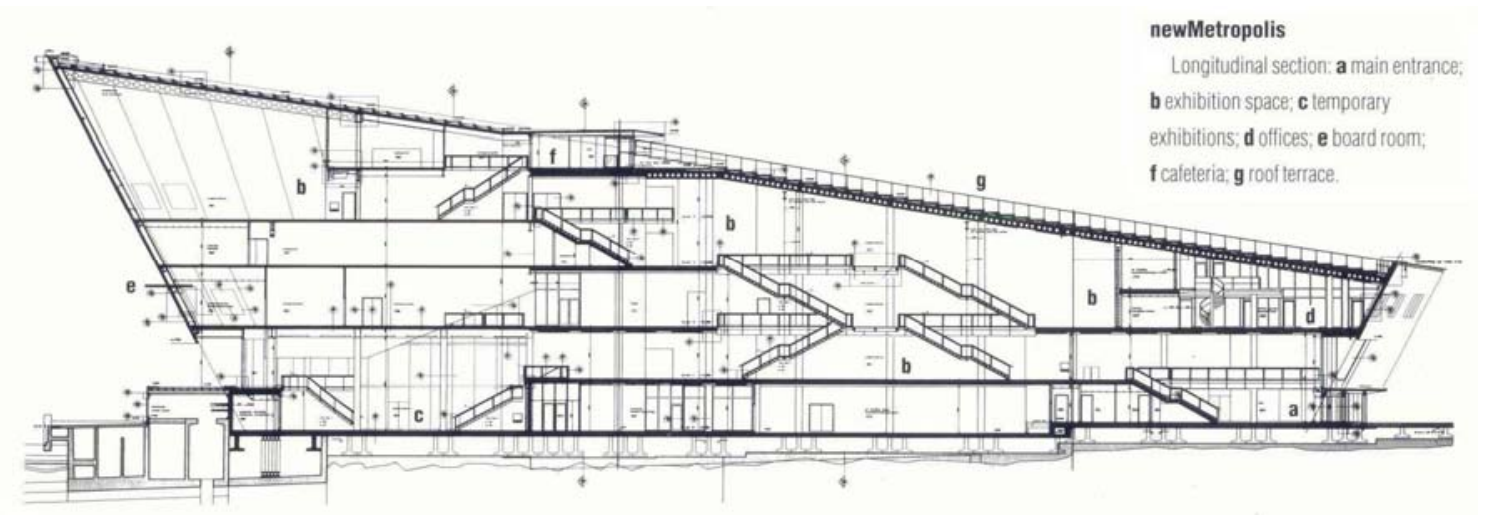

newMetropolis

1 Second tloor plan

Key

a torecourt, b pedestrian bridge, $\mathbf{c}$ housing

for tunnel flood gates d main entrance

e carreers office, f workshop, gtemporan

exhibitions, h shop $\mathbf{k}$ exhibition area.

$m$ void. $n$ offices, p loading window

q cinema/lecture theatre, $r$ thack-bor

theatre, $\mathbf{s}$ board room, $\mathbf{t}$ quayside.

u elevatot:

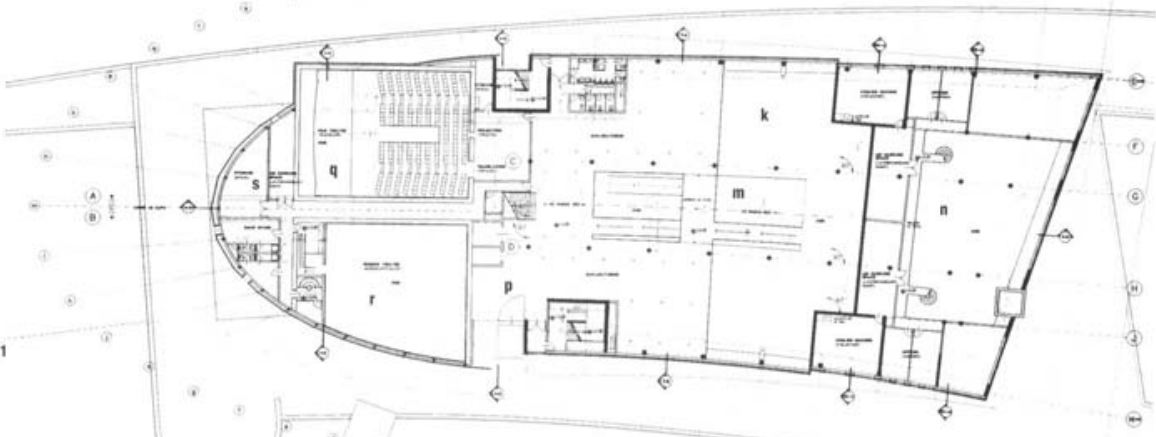

Fig. 23. Acima - Corte longitudinal. Buchanan, 2000, p. 55. Abaixo - Planta 2o Piso. Buchanan, 2000, p. 50.

\footnotetext{
103 BUCHANAN, 2000, p. 40.

${ }^{104}$ Ibidem, p. 39; ROCCA, 1997, p. 12.
} 
O orçamento apertado levou a algumas simplificações, principalmente com relação a acabamentos e detalhamentos. Todos os materiais são aparentes, com exceção das paredes, argamassadas e pintadas. A indústria local não respondeu bem às especificações, apesar das simplificações: as superfícies galvanizadas e o concreto aparente apresentam aspecto mal-acabado ${ }^{105}$.

O cliente exigiu a eliminação da seqüência de iluminação zenital. Ela teria se constituído, se executada, num "percurso com iluminação natural" que também traria a luz natural para todos os pisos de exposição. A decisão do cliente está relacionada com a opção por excluir os elementos históricos disponíveis em seu acervo e focar as exposições em displays interativos, que, na sua maioria possuíam telas melhor observadas sob luz tênue ${ }^{106}$. Sem a luz natural, entretanto, o efeito arquitetônico pretendido foi comprometido ${ }^{107}$.

Do lobby de entrada com pé-direito duplo é possível perceber imediatamente o arranjo espacial interno do edifício ${ }^{108}$, com a progressiva ampliação do espaço acontecendo ao longo da escadaria central ${ }^{109}$. Segundo Rocca, o espaço interno uniforme contrasta com a "força surrealista do exterior" 110 .

Completando a volumetria do edifício, existe um teatro flexível, com 200 lugares, que funciona também como cinema e auditório. Seu volume se projeta para fora da geometria pura da proa, criando uma descontinuidade intencional ${ }^{111}$. Em outra situação, a oficina onde se preparam as exibições pode ser observada pelo público - recurso que Piano já havia usado em projetos anteriores ${ }^{112}$.

\footnotetext{
105 BUCHANAN, 2000, p. 45.

106 Ibidem, p. 38.

${ }^{107}$ Ibidem, p. 41.

108 Ibidem, p. 41.

${ }^{109}$ ROCCA, 1997, p. 12.

${ }^{110}$ Ibidem, p. 13.

111 BUCHANAN, 2000, p. 45.

112 Ibidem, p. 41. Notadamente, The Menil Collection.
} 
A cobertura pode ser acessada pela rampa ou por um elevador, que a liga com o lobby $^{113}$. Ali há um restaurante que se abre para um terraço, com vista panorâmica para a cidade velha - provavelmente a única de Amsterdã, segundo Piano ${ }^{114}$. Isso ocorre porque a Holanda é um país de topografia plana ${ }^{115}$, constituído em grande parte por aterros ou diques. Essa vista, que contrasta com a introversão dos espaços de exibição, reconecta o Nemo com a cidade e, em dias ensolarados, fica lotada. Entretanto, a idéia de que esse espaço tão isolado, elevado e exposto pudesse se tornar um local de importante convergência da cidade é exagerada, segundo Buchanan ${ }^{116}$ e o próprio Piano. A cobertura é, de fato, um terraço, e não uma praça ${ }^{117}$. Assim, é o edifício como um todo que dialoga com a cidade, ou o porto, e não a sua cobertura ${ }^{118}$.

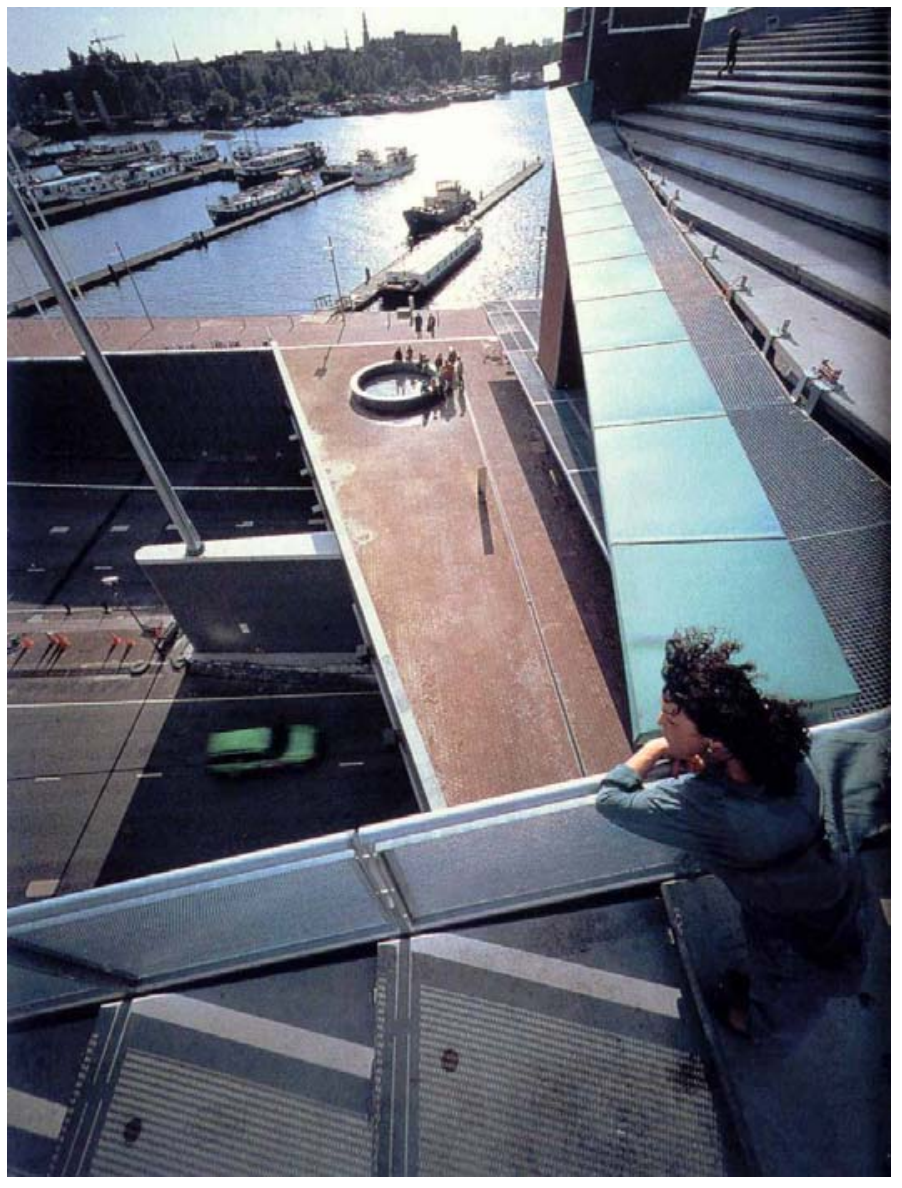

Fig. 24. Vista da cidade a partir da cobertura do edifício. Buchanan, 2000, p. 48.

\footnotetext{
113 BUCHANAN, 2000, p. 45.

${ }^{114}$ RENZO, 1997, p. III.

115 BUCHANAN, 2000, p. 39.

${ }^{116}$ Ibidem, p. 52.

${ }^{117}$ ROCCA, 1997, p. 13.

118 Ibidem, p. 13.
} 
Buchanan conclui afirmando que, de forma geral, o Nemo foi um sucesso imediato de crítica e público ${ }^{119}$.

O site da instituição divulga dados de visitação entre os anos 2000 e 2008: a freqüência tem subido ano a ano, iniciando em 2000 com menos de duzentas mil pessoas e atingindo a marca de quatrocentas mil pessoas em 2008.

${ }^{119}$ BUCHANAN, 2000, p. 52. 
6.1.4 Rose Center for Earth and Space (American Museum of Natural History), Nova Iorque, EUA

Introdução. Origens e contexto histórico.

O Rose Center for Earth and Space faz parte do American Museum of Natural History $(A M N H)$, e se localiza em Nova Iorque, EUA, tendo sido inaugurado em 2000, com custo total de 210 milhões de dólares ${ }^{120}$. O AMNH é muito mais antigo, tendo sido criado em 1869.

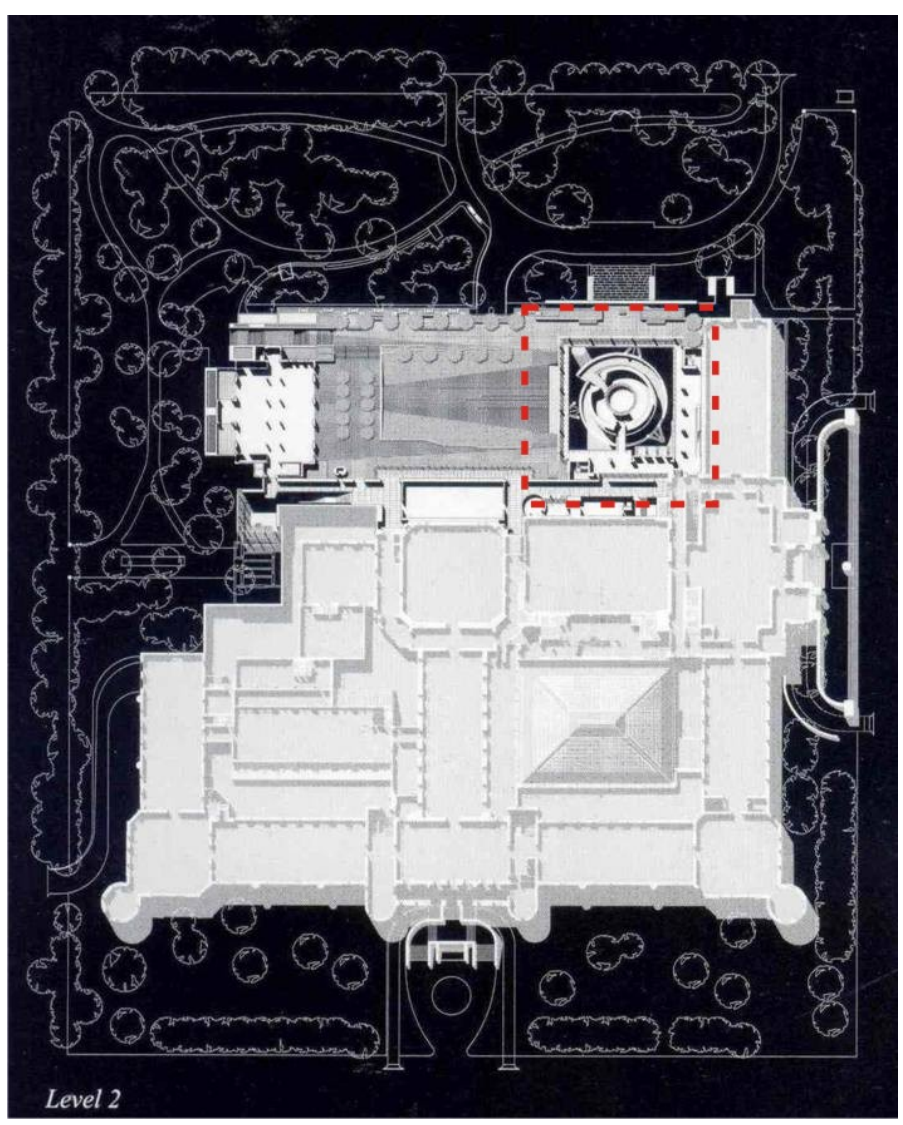

Fig. 25. Implantação do AMNH, com destaque em tracejado vermelho para o Rose Center. 2000. GA Documents, 63, p. 49.

I mplícito em seu nome está o fato de que a maior parte do AMNH é dedicada à história natural. O Rose Center é uma ala relativamente pequena do museu com atividades ligadas à astronomia e ao planeta Terra. Portanto, o conjunto não é um centro de ciências típico. No entanto, por abrigar diversas áreas do conhecimento e

\footnotetext{
${ }^{120}$ SIREFMAN, 2000, p. 42.
} 
ter no Rose Center um tema extremamente interessante do ponto de vista arquitetônico e museológico, foi incluído no nosso estudo.

Localização

$\mathrm{O} A \mathrm{MNH}$ - no qual se insere o Rose Center - ocupa um quarteirão inteiro que se constitui no Theodore Roosevelt Park, adjacente ao Central Park. O projeto do Rose Center inclui também um terraço público de cerca de $4.000 \mathrm{~m}^{2}$ de área e projeto paisagístico de Kathryn Gustafson, baseado metaforicamente num eclipse lunar. Ele faz a conexão com o Theodore Roosevelt Park (restaurado) ${ }^{121}$, e através desse, com o Central Park.

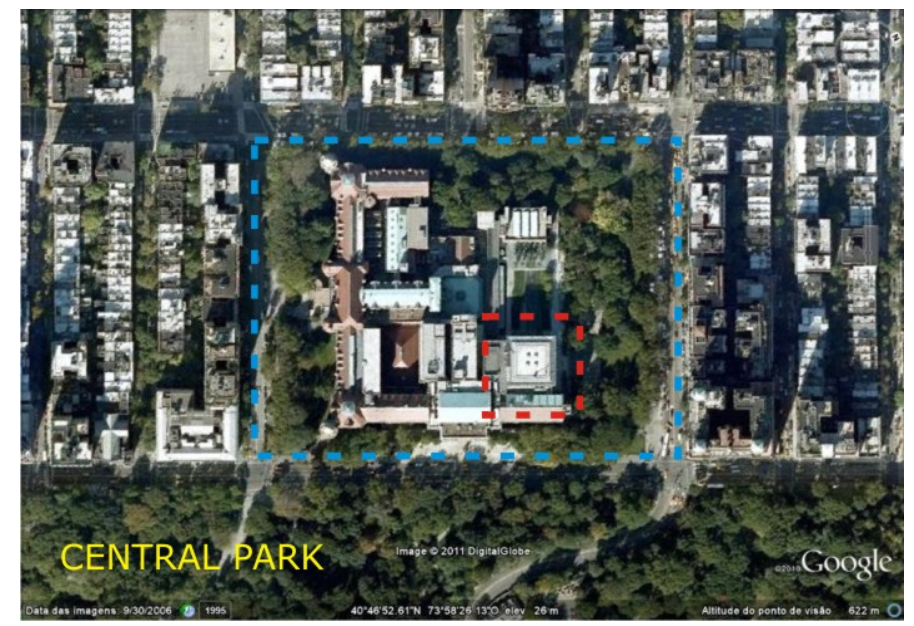

Fig. 26. Foto aérea. Theodore Roosevelt Park em tracejado azul. O conjunto edificado corresponde ao AMNH. Rose Center em tracejado vermelho. Abaixo, o Central Park. Google, 2008. I magem modificada pelo autor.

O edifício

O edifício do Rose Center é um anexo do AMNH pré-existente. O projeto arquitetônico, de autoria de Polshek Partnership Architects, foi desenvolvido entre 1994 e 1997, tendo a obra sido executada entre 1997 e $2000^{122}$. No Rose Center houve uma grande simbiose entre a arquitetura e a museologia - de autoria de

\footnotetext{
${ }^{121}$ FUTAGAWA, 2000, p. 48; LARSON, 1999, p. 105.

${ }^{122}$ FUTAGAWA, 2000, p. 48.
} 
Ralph Appelbaum Associates: “Invertendo as noções tradicionais de exposição e fazendo da arquitetura ela mesma uma exibição, o Rose Center é essencialmente um exemplo de exposição habitável" ${ }^{123}$.

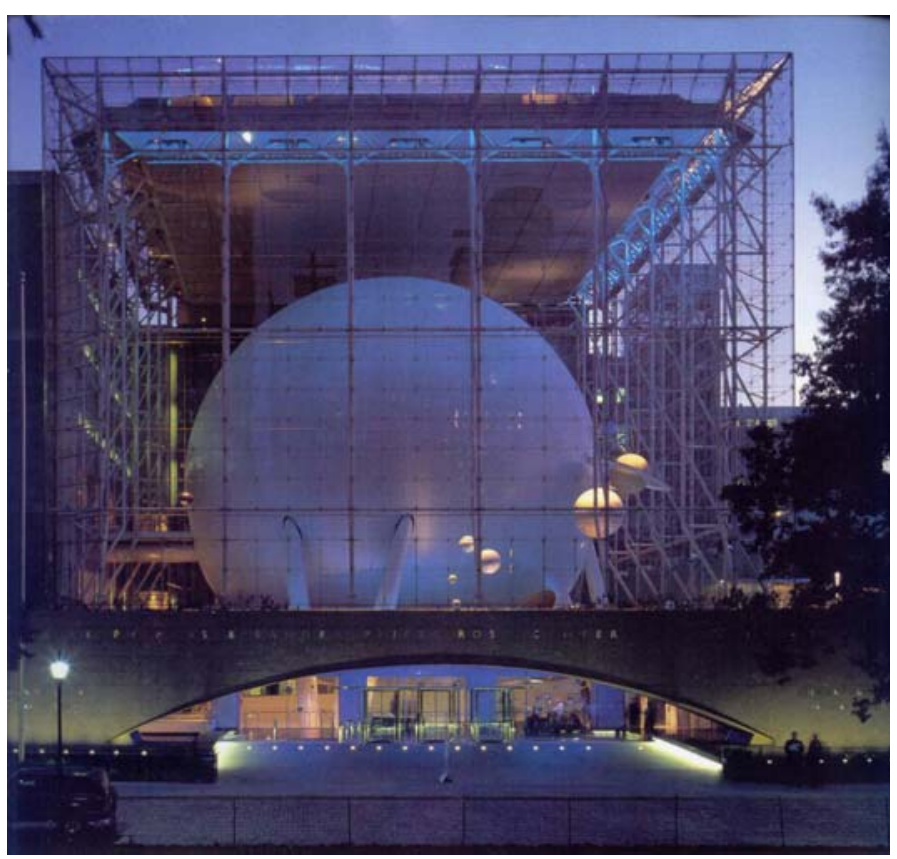

Fig. 27. Vista geral e entrada.

2000. GA Documents, 63, p. 50.

Essa relação intrínseca entre arquitetura e museologia torna-se clara na "Cosmic Pathway" (ver Capítulo 4, tópico 4.3) - um caminho helicoidal que, ao mesmo tempo em que dá acesso à esfera no interior da qual estão o Space Theater (planetário) e o Big Bang Theater (sala de apresentação com foco no surgimento do universo), é uma exposição que representa uma viagem de 13 bilhões de anos pela história do universo ${ }^{124}$.

A esfera, revestida de alumínio, tem 26,5 m de diâmetro, e está inserida no centro de um cubo de $36,5 \mathrm{~m}$ de lado, com as suas fachadas norte e oeste constituindo-se em cortinas de vidro, "as maiores [... ] nos Estados Unidos [em 2000]" ${ }^{125}$. Segundo Polshek, essa transparência objetiva tornar a arquitetura "visualmente acessível" e

\footnotetext{
123 SIREFMAN, 2000, p. 42.

124 Ibidem, p. 42; LARSON, 1999, p. 105; FUTAGAWA, 2000, p. 48.

125 SIREFMAN, 2000, p. 42; LARSON, 1999, p. 105.
} 
“tão refinada quanto possível" ${ }^{126}$. Futagawa, por outro lado a interpreta como uma declaração da "inteligibilidade dos questionamentos científicos" 127.

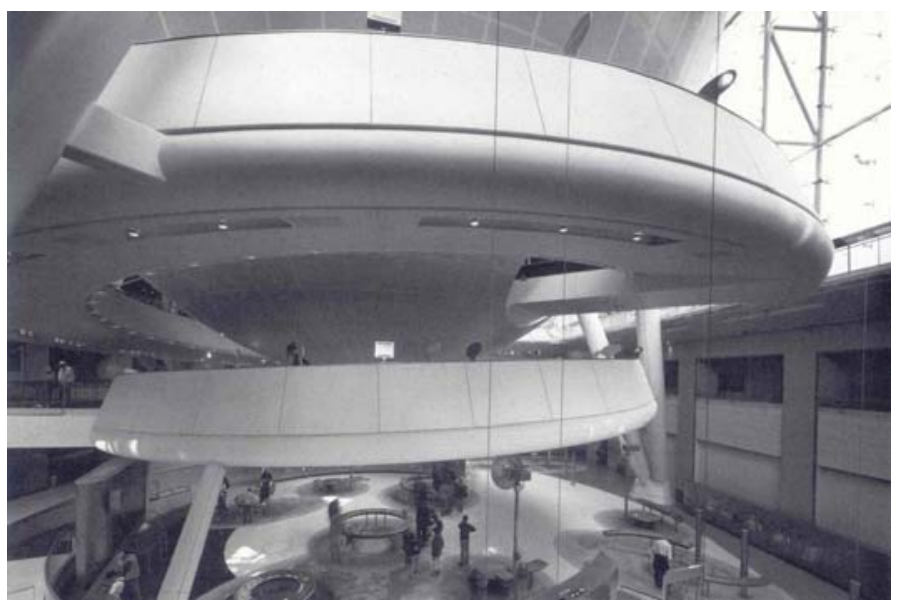

Fig. 28. Cosmic Pathway. 2000. GA Documents, 63, p. 56 .

As duas mil toneladas da esfera são suportadas por três pares de colunas inclinadas de aço ${ }^{128}$. Segundo Futagawa, a esfera é o "coração icônico e programático" do projeto. É um símbolo universal da astronomia e uma forma platônica "vibrante". “[...] a arquitetura do Rose Center cria um paradigma simples do universo natural através de abstrações formais e diálogos espaciais" ${ }^{129}$.

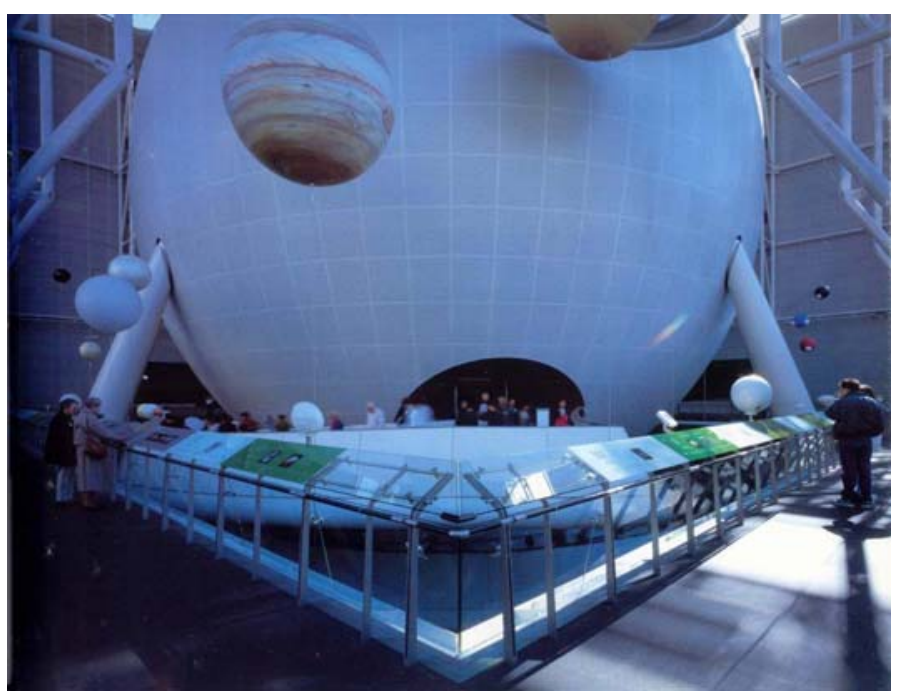

Fig. 29. Visualiza-se apenas duas colunas. 2000. GA Documents, 63, p. 56.

\footnotetext{
${ }^{126}$ LARSON, 1999, p. 105.

${ }^{127}$ FUTAGAWA, 2000, p. 48. Tradução nossa. No original, “accessibility of scientific inquiry”. ${ }^{128}$ SIREFMAN, 2000, p. 42; LARSON, 1999, p. 105.

${ }^{129}$ FUTAGAWA, 2000, p. 48. Tradução nossa.
} 
“Crítico para o conceito do projeto é a aparente independência da esfera em relação

à estrutura circundante e sua cortina de vidro transparente e a rampa helicoidal que envolve a esfera" ${ }^{130}$. Um dos sócios de Polshek, Todd Schliemann, afirma que buscaram formas de fazer a arquitetura se mover, sem sucesso ${ }^{131}$. A aparente independência e leveza da esfera se devem ao fato de apenas um par de colunas ser visto ao mesmo tempo de qualquer ponto do edifício. Por outro lado, a simetria da esfera e do cubo é quebrada pela multiplicidade de percursos, na qual se inclui também a Cosmic Pathway. ${ }^{132}$

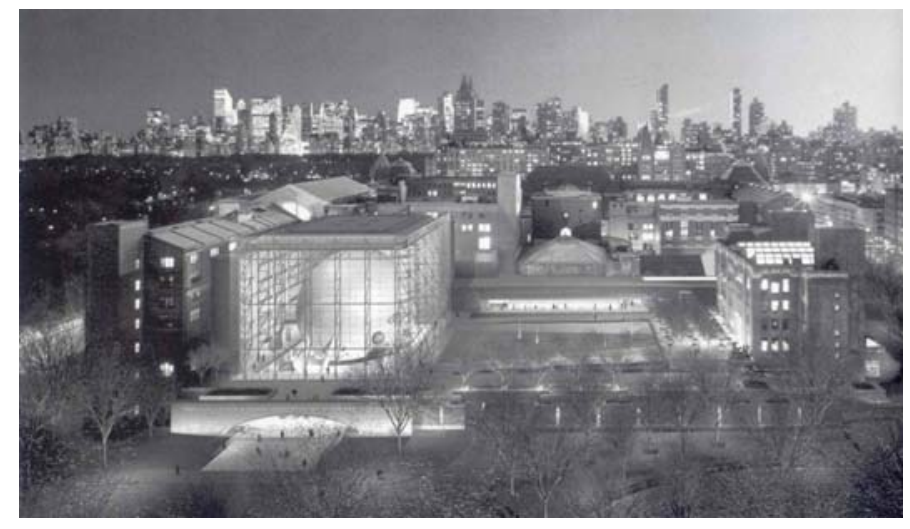

Fig. 30. Vista geral noturna. O Central Park fica à esquerda. 2000. GA Documents, 63, p. 52.

São várias as intenções conceituais declaradas do projeto: criar uma arquitetura acessível ao público e que expressasse inventivamente a missão progressista de pesquisa e educação em ciências naturais do $\mathrm{AMNH}$; criar espaços que comportassem exibições didáticas ${ }^{133}$ integradas para a promoção do entendimento público das ciências astronômicas; melhorar a inserção urbana do AMNH; e, finalmente:

Dramatizar o estudo da Terra e do espaço através da criação de uma arquitetura metafórica que atraia um número crescente de adultos e crianças para participar fisicamente e intelectualmente nos programas de educação e exibição dessa grande instituição científica ${ }^{134}$.

\footnotetext{
${ }^{130}$ FUTAGAWA, 2000, p. 48. Tradução nossa.

${ }^{131}$ LARSON, 1999, p. 105.

${ }^{132}$ FUTAGAWA, 2000, p. 48.

133 No original, "interpretive".

${ }^{134}$ FUTAGAWA, 2000, p. 48. Tradução nossa. Grifo nosso.
} 
Para atingir esses objetivos os autores buscaram criar o que chamam poeticamente de "catedral cósmica" ${ }^{135}$,

uma experiência espacial articulada que irá impressionar e inspirar variados visitantes com o entendimento das maravilhas do nosso universo e o poder da pesquisa científica da mesma forma que os espaços monumentais das catedrais medievais inspiraram os peregrinos. ${ }^{136}$

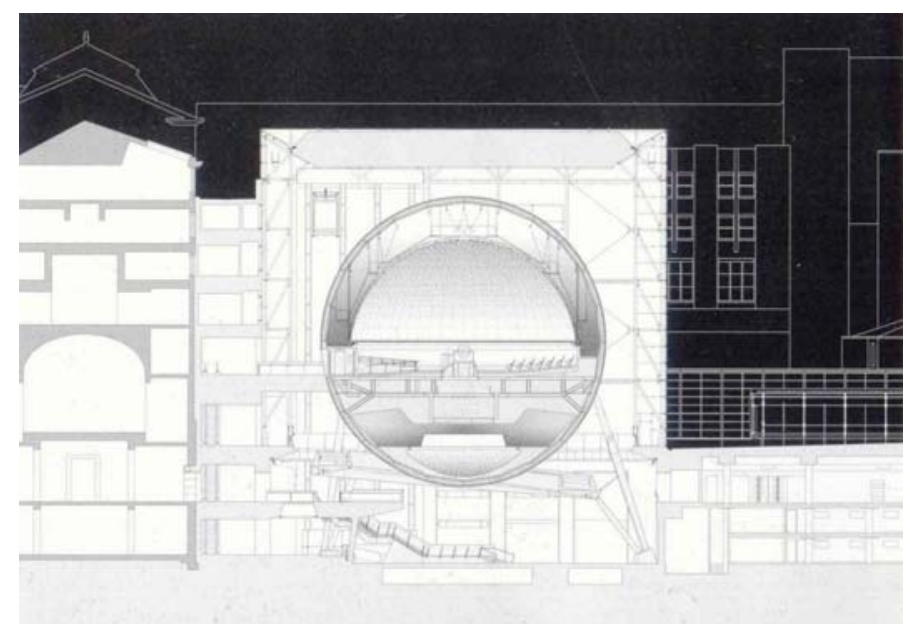

Fig. 31. Corte, onde se verifica a configuração realmente completa da esfera. 2000. GA Documents, 63, p. 52.

${ }^{135}$ FUTAGAWA, 2000, p. 48; SIREFMAN, 2000, p. 42.

${ }^{136}$ FUTAGAWA, 2000, p. 48. Tradução nossa. 
6.1.5 Outros centros de ciências relevantes: Museo Interactivo Mirador (MIM), Santiago, Chile; Exploratorium, São Francisco, EUA; Cosmocaixa Barcelona, Barcelona, Espanha; Carnegie Science Center, Pittsburgh, EUA (concurso com idéias de Tschumi)

Museo Interactivo Mirador (MIM), Santiago de Chile

O projeto do arquiteto Gonzalo Mardones Viviani foi o vencedor, em 1999, do concurso de arquitetura para a concepção do MIM. Inaugurado em março de 2000, o MIM é um museu interativo de ciências no Parque Brasil, em Santiago, Chile. Mardones afirma que o centro tem uma expressão espacial que o remete ao Chile: a Cordilheira, o Vale, o Mar do Chile ${ }^{137}$. Ele é composto por diversos edifícios. “Los edificios asumen formas primarias, las cuales son fácilmente reconocibles por niños y adultos" ${ }^{138}$. Mas o edifício mais interessante é o semi-enterrado, formado pelos taludes gramados - que nos lembra as Cavernas de Altamira (ver fig. 17, p. 157). "Se debe dejar atraer por la curiosidad y caer dentro casualmente" ${ }^{139}$.
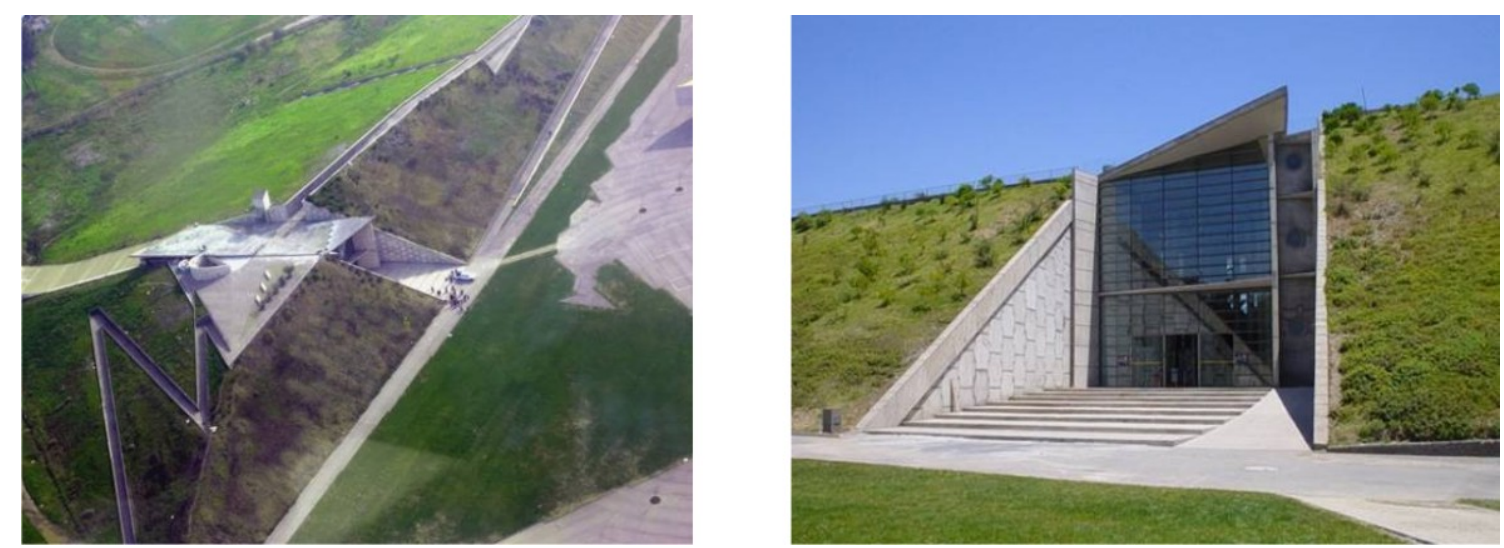

Fig. 32. À esquerda, vista geral do edifício semi-enterrado. À direita, foto da entrada. 2010. Mardones - homepage do arquiteto.

Um comentário museológico interessante do autor é que não se apresentam percursos únicos, mas variáveis.

\footnotetext{
${ }^{137}$ MARDONES, 2010.

${ }^{138}$ Ibidem.

${ }^{139}$ Ibidem.
} 
Criado em 1969, o Exploratorium é relevante pelo impacto que teve em outras instituições e pela recorrência de sua citação nos textos dos autores que abordam os centros de ciências com enfoque educacional ou de divulgação científica. Segundo Gaspar, “muitos museus já apresentavam há muito tempo materiais desse tipo [experimentos interativos], [...] mas foi o Exploratorium quem os utilizou maciçamente" ${ }^{140}$.

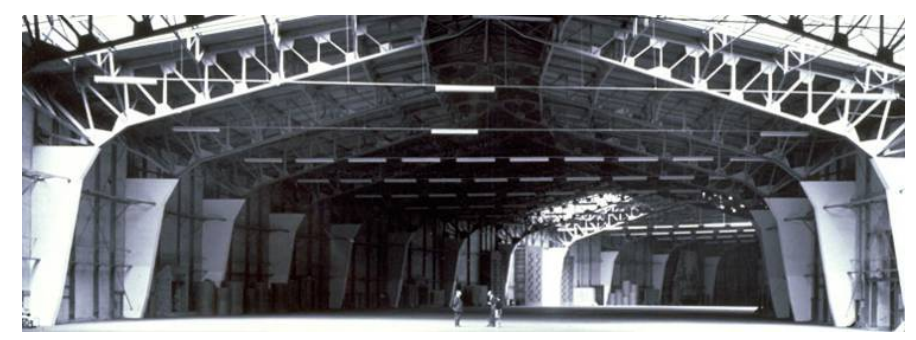

Fig. 33. Palace of Fine Arts, antes de sua ocupação pelo Exploratorium. S/ data. Homepage do Exploratorium.

O edifício do Exploratorium é o "Palace of Fine Arts", com aspecto de hangar e “originalmente projetado por Bernard Maybeck como estrutura temporária para a Panama Pacific Exhibition", de 1915. Com área total pouco inferior a 15 mil metros quadrados $^{141}$, consiste num pavilhão porticado em meia-lua, cujo espaço interior constitui um "ambiente austero - quase de laboratório" 142.

Houve iniciativas de modernização nos anos 1990, incluindo o desenvolvimento de um master plan, com consultoria de Stastny Brun Architects of Portland, para ampliar em cerca de cinco mil metros quadrados a área de exposição, através da transferência de áreas administrativas e de oficinas para outro edifício (uma antiga base do exército, chamada de Presídio). No ano de 1998 Esherich Homsey Dodge and Davis (EHDD) ganhou o concurso de idéias para aplicar o master plan. Sua proposta incluía "restauro de partes da fachada histórica, conexão do sítio atual

\footnotetext{
${ }^{140}$ GASPAR, 1993, Capítulo IV - Item 3.2 - Objetos e experimentos - formas de expor e apresentar. Ver também QUIN, 1990, p. 243.

${ }^{141}$ SAN FRANCISCO’S, 1998, p. 38; DANILOV, 1982, p. 139.

${ }^{142}$ GIL, 1988, p. 82.
} 
com o 'Presidio' através de uma passarela de pedestres, e ligação do complexo com quatro teatros experimentais" 143 .

Museo de la Ciencia (Cosmocaixa), da Fundação "La Caixa", em Barcelona, Espanha.

O Museo de la Ciencia foi criado em 1977 e aberto ao público em 1980. Segundo $\mathrm{Gil}^{144}$, é o museu espanhol que recebe o maior número de visitantes por metragem quadrada. O museu tem, conforme comentado anteriormente (no Capítulo 4, tópico 4.2), exposições e abordagens diferenciadas para os grupos de faixa etária entre zero e seis e de 6 a 10 anos. É uma instituição cujos edifícios não foram construídos especialmente para seu uso, mas reconvertidos: originalmente constituía-se num conjunto religioso que incluía igreja ${ }^{145}$. O projeto de reconversão é de 1979, da autoria dos arquitetos Jordi Garcés e Enric Sòria ${ }^{146}$, totalizando pouco mais de $4.300 \mathrm{~m}^{2}$, com execução de obras entre 1980 e $1987^{147}$
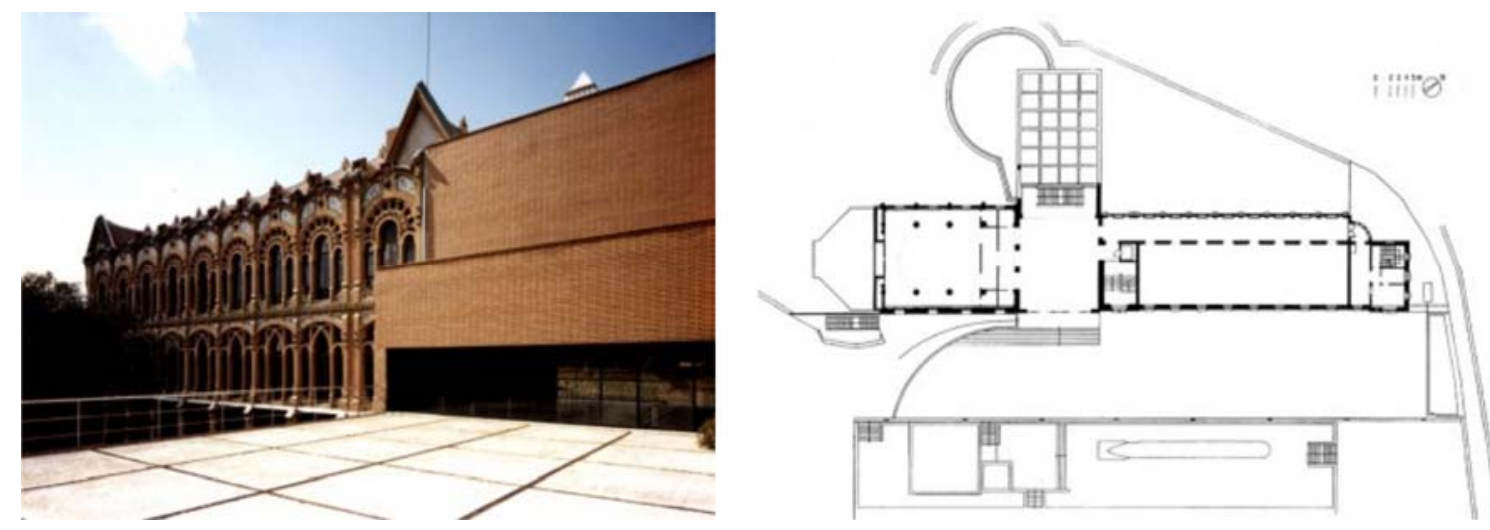

Fig. 34. Reconversão. À esq., foto. À dir., planta. 1979. J ordi Garcés, homepage do arquiteto, 2010.

\footnotetext{
143 SAN FRANCISCO'S, 1998, p. 38.

${ }^{144}$ GIL, 1988, p. 86.

145 AB'SÁBER, 1998, p. 28-30.

146 JORDI, 2010; MONTANER, 1995, p. 127.

147 JORDI, 2010.
} 
Somente em 2004, entretanto, o museu foi absorvido pela Obra Social Fundación "La Caixa" e passou a se chamar Cosmocaixa, quando sofreu significativa ampliação, de autoria dos arquitetos Robert y Esteve Terradas, que multiplicou sua área por quatro. A exposição mais interessante é uma reconstituição natural da selva amazônica brasileira, com mil metros quadrados, incluindo fauna, flora, ambiente aquático, terrestre e aéreo (copas de árvores) ${ }^{148}$.

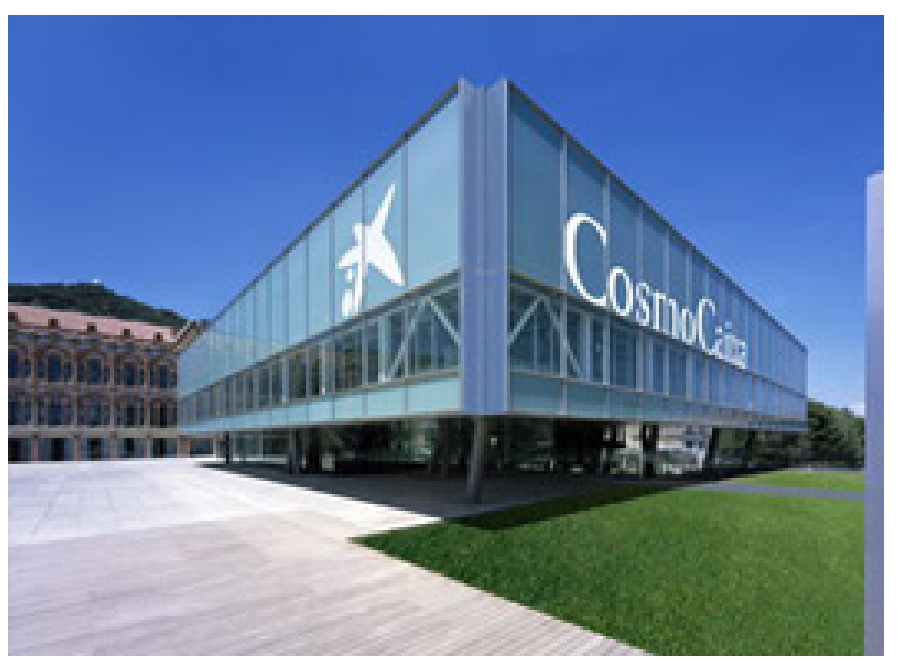

Fig. 35. Ampliação. Anos 2000. Cosmocaixa, 2010.

Carnegie Science Center, Pittsburg, EUA

O museu foi inaugurado em 1991. Entretanto, originou-se da fusão entre o Carnegie Institute, cujos Museus de História Natural e de Arte remontam a 1895, e o Buhl Planetarium and Institute of Popular Science, criado em 1939, do qual herdou o planetário ${ }^{149}$. Em 2000 houve um concurso fechado para a ampliação das instalações, com aumento de área de cerca de 15 mil metros quadrados, do qual participaram Bernard Tschumi, Jean Nouvel, Peter Eisenman, Daniel Libeskind e Ben van Berkel ${ }^{150}$. Tschumi e Eisenman foram eliminados ${ }^{151}$, mas Tschumi

\footnotetext{
${ }^{148}$ COSMOCAIXA, 2010.

${ }^{149}$ CARNEGIE, 2010.

${ }^{150}$ FIVE, 2001, p. 32.

${ }^{151}$ EISENMAN, 2001, p. 30.
} 
aproveitou para incluir o projeto em seu livro Event Cities, v. $3^{152}$. Aparentemente, o concurso acabou não levando à execução da ampliação por nenhum dos escritórios envolvidos.

Essencialmente o projeto de Tschumi para o Carnegie Science Center consistia em criar um envelope externo ${ }^{153}$ que envolvia quase totalmente o edifício, gerando um espaço intermediário ${ }^{154}$ entre essa nova casca e as fachadas existentes. Essas fachadas eram parcialmente removidas para permitir a ampliação de cerca de $6.500 \mathrm{~m}^{2} .{ }^{155}$

Os três objetivos de Tschumi eram: 1) Criar uma nova experiência espacial na qual o lado externo do edifício existente é simultaneamente o interior do novo edifício e a nova pele é ao mesmo tempo a vedação real e um suporte para projeções de realidade virtual; 2) "Definir um novo tipo de centro de ciências onde educação e experimentação, tecnologia, e inovação estão integradas - uma espécie de laboratório gigante que é acessível ao maior público possível. Para atingir esse objetivo, o projeto apresenta uma configuração simples e clara, composta por pisos extensos que possibilitam vários percursos $[\ldots]$ "; 3) "Transformar o conceito em um elemento marcante no panorama da cidade $[\ldots]$ : um envelope arredondado, de aço inoxidável polido [...]. Fortemente diferenciado do Pittsburgh Steeler's stadium, adjacente, ele não parece com nada existente na cidade" ${ }^{156}$.

Com relação a esses objetivos, alguns comentários devem ser feitos. O "envelope" provavelmente geraria uma "experiência espacial nova", interessante, e a materialidade proposta deveria destacar o edifício na paisagem, constituindo-o em um elemento marcante da cidade - difícil de dizer se positivo ou negativo. Entretanto, a afirmação de que ele propõe um "novo tipo de centro de ciência"

\footnotetext{
152 TSCHUMI, 2005.

${ }^{153}$ Ibidem, p. 117. No original, "phagocyte" e "cell”.

${ }^{154}$ Ibidem, p. 114. No original, "in-between space".

${ }^{155}$ Ibidem, p. 117.

${ }^{156}$ Ibidem, p. 117. Tradução nossa.
} 
parece-nos puro discurso, superficial, denotando pouco aprofundamento sobre o tema dos museus e centros de ciências. O que ele descreve é exatamente o modelo de centro de ciência que tem sido feito há várias décadas, sem nenhuma novidade.

London Science Museum e Victoria and Albert Museum

Parte do conteúdo da Exposição Universal de 1851 foi compor o acervo do South Kensington Museum of Industrial Arts em 1857, que posteriormente originou dois outros museus: o Victoria and Albert Museum em 1908, de belas artes, e o London Science Museum em 1909, que herdou seu acervo industrial ${ }^{157}$.

No início o London Science Museum tinha "uma proposta explícita de se remeter às últimas novidades em Ciência e Tecnologia" ${ }^{158}$. Passou, entretanto, a focar muito mais a história da ciência e da tecnologia desde os anos 1920 até o início dos anos 1990, quando então retornou a priorizar a ciência contemporânea, com, por exemplo, um programa de pequenas exposições temporárias chamado Science Box ${ }^{159}$, criado em 1993, e uma nova ala de exposições denominada Welcome Wing, aberta em $2000^{160}$.

Montaner associa o London Science Museum com três das suas oito posições tipológicas de museus. Inicialmente, com o modelo da caixa neutra ${ }^{161}$, depois com o museu-colagem, por configurar-se em “um sumário de diversos contêineres de épocas distintas" ${ }^{162}$, e finalmente com as formas de desmaterialização, à qual está

\footnotetext{
${ }^{157}$ GIL, 1988, p. 78; JACOMY, 2007, p. 18; GASPAR, 1993, Capítulo II - Museus de Ciências. Breve Relato Histórico; MONTANER, 1995, p. 125.

${ }^{158}$ MAYFIELD, 2007, p. 122.

${ }^{159}$ Ibidem, p. 122.

${ }^{160}$ Ibidem, p. 121.

${ }^{161}$ MONTANER, 2003, p. 28.

${ }^{162}$ Ibidem, p. 97.
} 
associada a sua ampliação de 2001, “com sua nova ala de descanso e exposições temporárias sobre a energia e os novos meios técnicos e científicos" ${ }^{163}$.

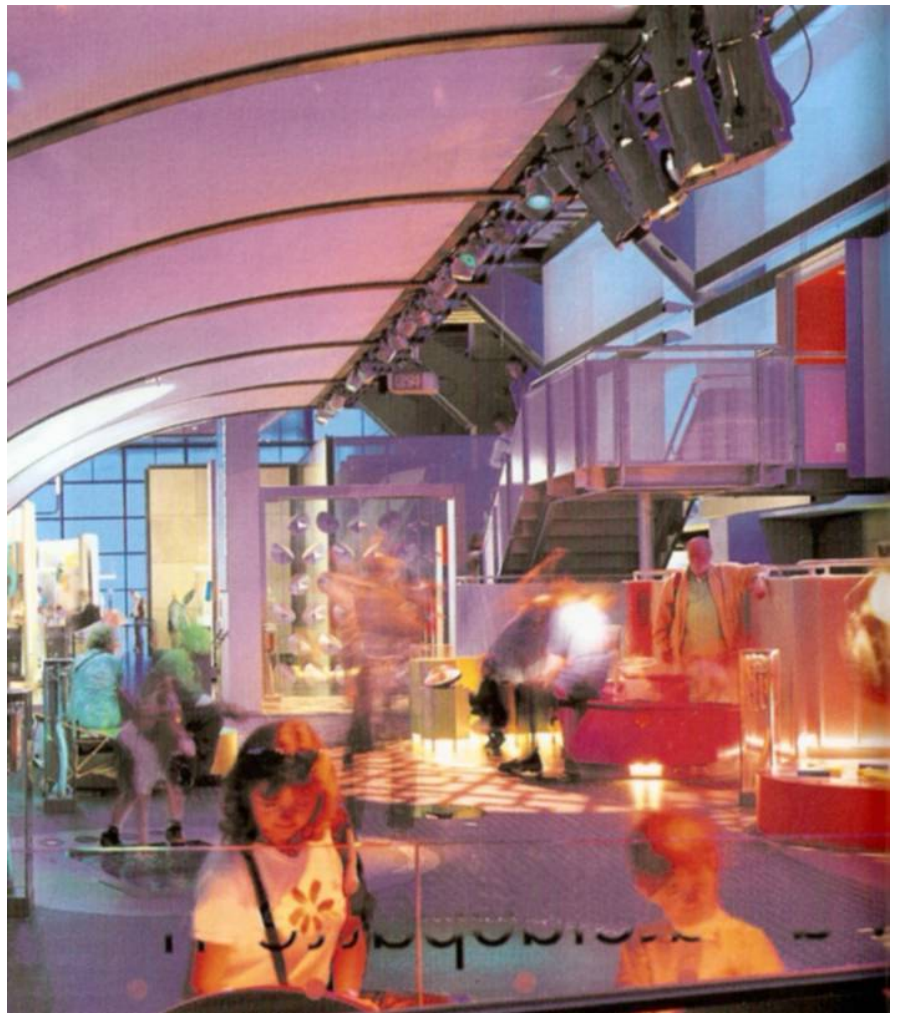

Fig. 36. Museu de Ciências de Londres. Ampliação. 2001. MONTANER, 2003, p. 146.

${ }^{163}$ MONTANER, 2003, p. 142-147. 


\subsection{Centros e museus de ciências brasileiros}

\subsubsection{Parque de Ciência e Tecnologia (USP), São Paulo, SP}

Introdução. Origens e contexto histórico.

O Parque de Ciência e Tecnologia da USP (Parque CienTec) foi criado oficialmente através de portaria do então Reitor Adolpho J osé Melfi, em dezembro de 2001.

Sua história, no que se refere ao local onde se instalou, inicia muito antes, e está fortemente ligada à Ciência brasileira ${ }^{164}$. O sítio abrigou no passado o Observatório de São Paulo, depois renomeado Instituto Astronômico e Geofísico da USP (IAG), cujas origens remontam ao ano de 1886, quando foi criada a Comissão Geográfica e Geológica de São Paulo. Ela deu inicio às observações meteorológicas regulares no Estado de São Paulo, e seu primeiro diretor foi o geógrafo norte-americano Orville Adalbert Derby. Na Comissão havia a Seção de Botânica e Meteorologia, chefiada pelo naturalista sueco Alberto Loefgren, auxiliado por F. J. C. Schneider.

Este passou a diretor do Serviço Meteorológico, criado a partir das iniciativas de Loefgren. Em 1902 Schneider foi substituído pelo engenheiro civil José Nunes Belfort de Mattos, que tinha também grande interesse em Astronomia e incluiu observações astronômicas com equipamentos próprios, pessoais, em suas atividades. Em 1907 o Serviço Meteorológico foi desmembrado da Comissão Geográfica e Geológica e subordinado à Secretaria da Agricultura, mas manteve a direção de Belfort de Mattos.

Em 1912 foi concluída a construção do Observatório de São Paulo, na Avenida Paulista, no 69, com uma cúpula astronômica giratória que consolidava a associação da Astronomia com o Serviço Meteorológico. Também o Serviço da Hora Oficial do Estado de São Paulo passou a ser responsabilidade do Observatório. Belfort de Mattos permaneceu como diretor até a sua morte, em 1926, quando foi

${ }^{164}$ MANTOVANI; MASSAMBANI, 2004a. 
substituído interinamente pelo engenheiro Eliezer Rodrigues dos Sanctos Saraiva. Em seguida, quem assumiu a direção, em 1927, foi o engenheiro geógrafo Alypio Leme de Oliveira, a figura histórica mais interessante para o nosso estudo, por sua influência na herança artística e arquitetônica do sítio.

Coube a Oliveira realizar duas importantes missões. Em primeiro lugar, reorganizou o Serviço Meteorológico, aglutinando oficialmente as atividades de observação astronômica e geofísica, passando o novo órgão a se chamar Diretoria do Serviço Meteorológico e Astronômico do Estado de São Paulo. A seguir, investigou um novo local mais adequado para a construção do novo observatório. Na Avenida Paulista as observações astronômicas eram prejudicadas pelo aumento da iluminação pública, e as geofísicas (sísmicas e eletromagnéticas) pela passagem dos bondes elétricos.

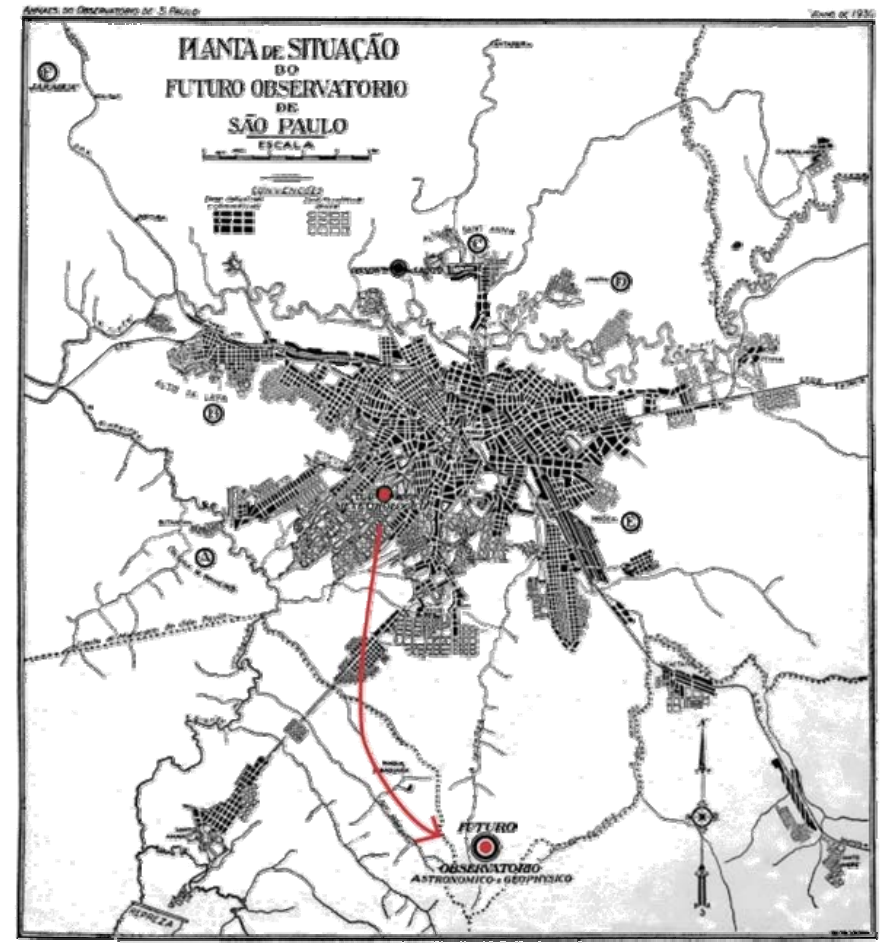

Fig. 37 - Desenho do projeto original (Oliveira, 1930), indicando o local do novo Observatório. Em vermelho, destaque do autor para a transferência da Av. Paulista para o então chamado Parque do Estado.

Em 1930, Oliveira escolheu criteriosamente o novo sítio, numa área do então denominado Parque do Estado - atualmente Parque Estadual das Fontes do 
I piranga (PEFI) ${ }^{165}$-, e concebeu o projeto arquitetônico. Acompanhou a execução dos dez edifícios originais, entre 1932 e 1941. Também em 1930, a Diretoria passou a se chamar Instituto Astronômico e Geofísico e foi anexado à Escola Politécnica. Em 1934, foi transformado em instituto complementar da recém-criada Universidade de São Paulo. Em 1946 foi incorporado definitivamente à USP como instituto anexo. Em 1955 Oliveira se aposentou, quando então assumiu a direção Abraão de Moraes, que permaneceu no cargo até sua morte em 1970.

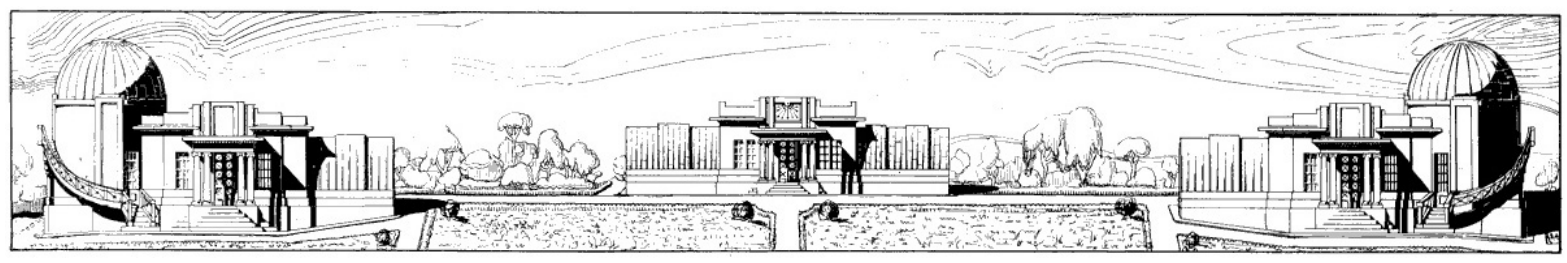

Fig. 38 - Elevação original da praça principal. Oliveira, 1930. Acervo digital do CienTec.

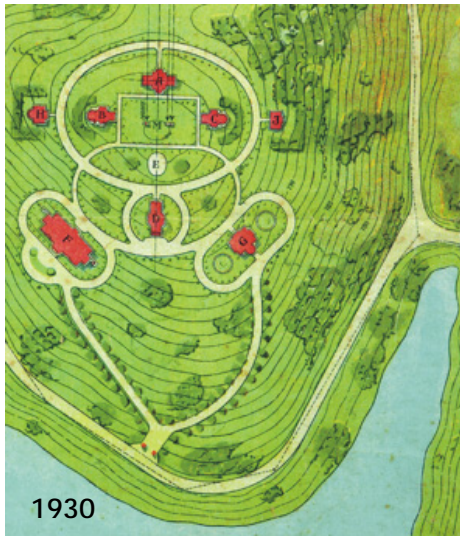

Implantação - Projeto original (Alypio Leme de Oliveira, 1930)

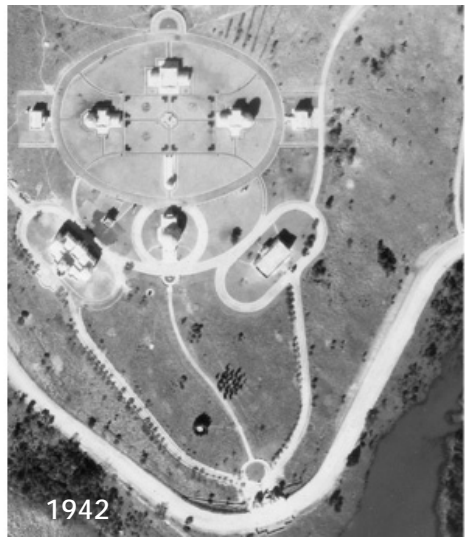

Foto aérea do conjunto concluído

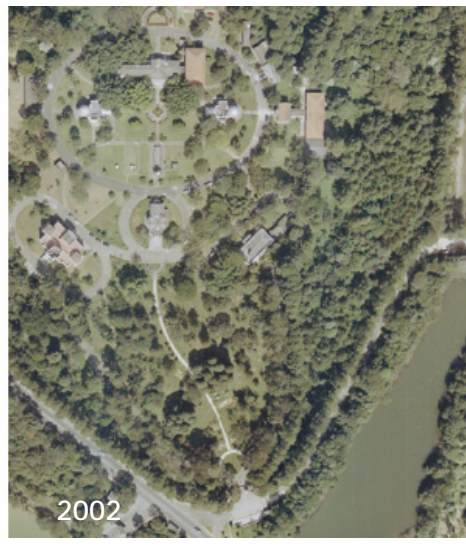

Foto aérea recente, com a inclusão de edifícios construídos ao longo da ocupação da área

Fig. 39 - Evolução da implantação, desde o projeto até os dias atuais. Acervo digital do CienTec.

Em 1972 o instituto foi transformado em unidade de ensino e pesquisa, e organizado em três departamentos: Astronomia, Geofísica e Meteorologia. Iniciouse então um lento processo de transferência dos departamentos para a Cidade Universitária Armando Salles de Oliveira, no Butantã, em São Paulo, com a construção ali de novos edifícios. Este processo foi concluído apenas 30 anos depois, em março de 2002.

\footnotetext{
165 O PEFI foi criado pelo decreto 52.281, em 12.08.1969, em substituição ao Parque da Água Funda. A área era, e ainda é, popularmente conhecida como Parque do Estado. Estão sendo feito esforços para fixar o nome oficial, principalmente em virtude da alusão às fontes do Riacho do Ipiranga.
} 
À medida que o processo ia se dando surgia uma importante questão: qual a nova destinação do sítio. Vários pontos principais foram considerados.

O primeiro deles foi o patrimônio histórico, artístico, arquitetônico, e ambiental, que resultam em um "conjunto arquitetônico extremamente homogêneo" 166, com “harmonioso convívio das construções com sua área envoltória" ${ }^{167}$. Essa harmonia se deve em parte ao "traçado regulador" que os organiza ${ }^{168}$.

Em segundo lugar, foi detectada grande carência de serviços culturais em seu entorno, na região sul de São Paulo ${ }^{169}$. Por outro lado, inseridos no mesmo PEFI estão também o Zoológico e o Jardim Botânico, importantes centros de visitação em suas áreas.

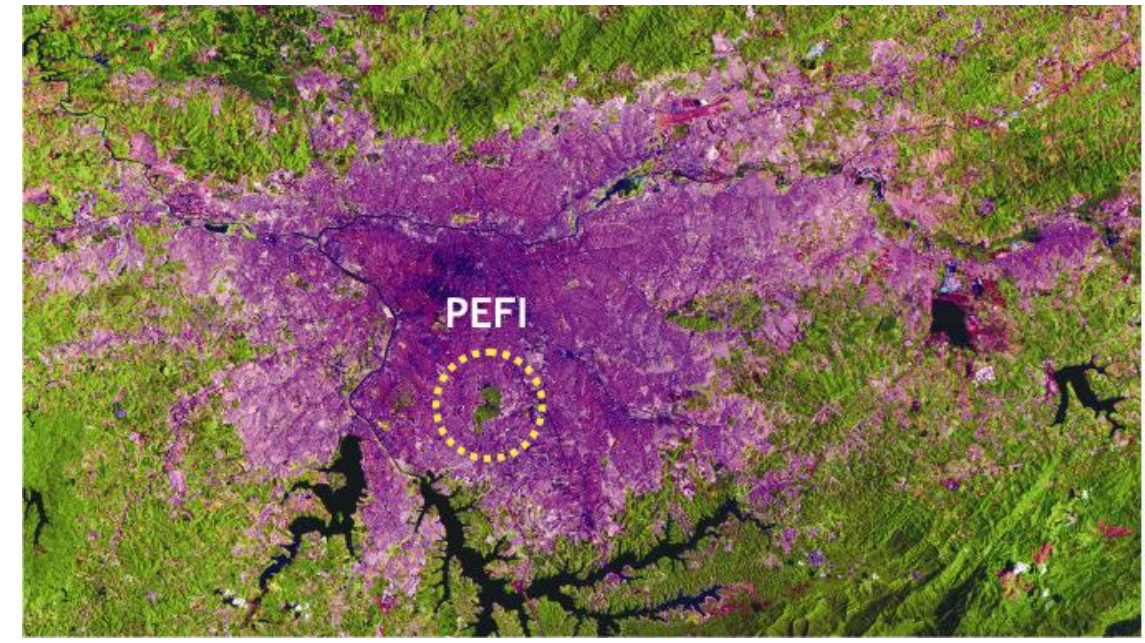

Fig. 40 - Foto de satélite. Em roxo a mancha urbana da metrópole de São Paulo. Em destaque (tracejado amarelo) o Parque Estadual das Fontes do I piranga (PEFI).

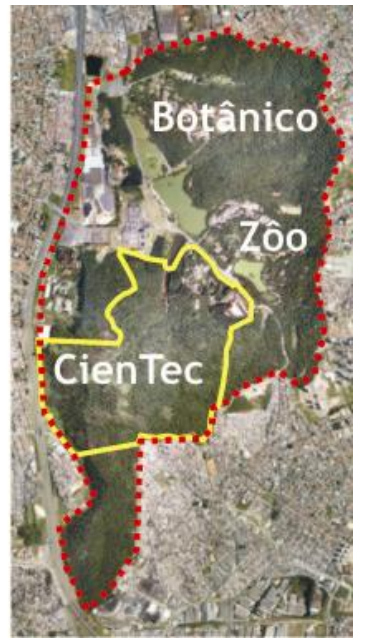

Fig. 41 - Foto aérea (1998) do PEFI. Em destaque a área do CienTec.

A partir destas considerações, optou-se por criar um Centro de Ciência e Tecnologia, que comporia no PEFI um núcleo de visitação com foco na vida animal (Zôo) e vegetal (Botânico), e nas demais ciências (o novo centro). Essas

\footnotetext{
166 TOLEDO, 1999, p. 1.

167 Ibidem, p. 1.

${ }^{168}$ Ver fig. 39, p. 182, e fig. 48, p. 191. Implantação, Projeto Original.

${ }^{169}$ MANTOVANI; MASSAMBANI, 2004a.
} 
instituições vizinhas têm influência potencial positiva, pois ao mesmo tempo em que atraem público, não competem diretamente com um centro de ciências ${ }^{170}$.

Esse centro - o Parque CienTec - foi formalmente constituído como um órgão da Pró-Reitoria de Cultura e Extensão Universitária da USP, garantindo-se assim a preservação do conjunto arquitetônico e do arranjo urbanístico do sítio. O projeto básico de restauro e reconversão para os dez edifícios foi concluído em $2003^{171}$.

Ao longo dos anos em que o IAG ocupou o sítio, desenvolveu no local prioritariamente atividades de ensino e pesquisa, e complementarmente atividades de extensão, nas áreas de Astronomia e Meteorologia ${ }^{172}$. É interessante observar que a idéia de promover atividades voltadas para o público estava presente nas intenções expressas por Oliveira em seu relatório de 1929, que justificava a escolha do novo local do Observatório:

[...] o local permitirá ao Observatório ser provido de meios para a educação

do grande público, conduzindo assim o estabelecimento a desempenhar função social tão importante como seu papel científico, o que aliás está previsto no regulamento baixado com a lei que organiza o Serviço Meteorológico ${ }^{173}$.

A criação do Parque CienTec, como conseqüência do agrupamento dos três departamentos e da estrutura administrativa do IAG na Cidade Universitária, parece-nos plenamente coerente com a sua inserção no entorno e com a história do sítio.

\footnotetext{
${ }^{170}$ ANDERSON, 1991, p. 24.

${ }^{171}$ MANTOVANI; MASSAMBANI, 2004b. Projeto de autoria dos arquitetos Paulo Bruna e Nestor Goulart Reis.

172 BICUDO; FORTI; BICUDO, 2002.

${ }^{173}$ SANTOS, 2005, p.76. Grifos nossos.
} 
Inserção Metropolitana

A localização do sítio no tecido urbano apresenta grande interesse, pois compreende cerca de um quarto do Parque Estadual das Fontes do Ipiranga (PEFI), o qual, por sua vez, representa $10 \%$ das áreas verdes do Município de São Paulo. Assim, o Parque CienTec é responsável pela preservação de 2,5\% das áreas verdes do município. Em seu entorno se encontram bairros habitacionais, como Jabaquara e Água Funda, e outros municípios, como São Bernardo e Diadema. A fronteira com Diadema, em particular, é caracterizada por habitações precárias e insalubres, com condições sanitárias inadequadas. É uma área bastante problemática, com grandes pressões de invasão e degradação da área do Parque, através do lançamento de esgoto e entulho, da construção de sub-habitações, do plantio de hortas e da realização de atividades ilegais como consumo de drogas e rituais com sacrifício de animais.

“Localizar um centro de ciências em um terreno ecologicamente frágil seria difícil de defender a menos que ele pudesse agir na preservação e proteção da área, ou incorporar a ecologia local em seus programas" 174. É o caso do Parque CienTec, cuja ação para a melhoria dessas condições é educativa, cultural e também operacional, com vigilância sistemática e contínua. As escolas públicas são atendidas gratuitamente, e há um esforço para se conseguir atingir em especial as escolas da região. Alguns eventos especiais abertos ao público em geral foram realizados ao longo dos anos, como apresentação de música erudita, música brasileira de raízes, palestras sobre temas diversos, observação na luneta, cursos de educação ambiental, etc.

${ }^{174}$ ANDERSON, 1991, p. 73. 
O conjunto original

Na época em que foram projetados (1929-1930) e construídos (1932-1941) os edifícios do Observatório, estava se dando no Brasil a mudança da técnica construtiva colonial da terra para as soluções em alvenaria de tijolos. O café introduziu os imigrantes brancos no país, e os brancos - imigrantes e nãoimigrantes - adotaram o tijolo como símbolo de modernidade ${ }^{175}$. Essa nova tecnologia só era dominada pela mão-de-obra estrangeira: mestres e pedreiros italianos, na sua quase totalidade ${ }^{176}$.

Lemos afirma reiteradamente em seu livro Alvenaria Burguesa ${ }^{177}$ o predomínio do Art Decó nessa mesma época - os anos 1930 de Getúlio Vargas. Do ponto de vista técnico, o concreto armado começou a ser "empregado sistematicamente" ${ }^{178} \mathrm{em}$ residências construídas sob influência desse estilo, mas sempre "escamoteado por revestimentos e tratamentos plásticos" ${ }^{179}$.

O concreto era conhecido no país antes disso, entretanto. Victor Dubugras empregou "o concreto armado calculado dentro de toda a sua potencialidade estrutural, ficando à vista todas as nervuras ao longo das linhas de influência de modo precursor" ${ }^{180}$ em 1906, na Estação de Estrada de Ferro de Mairinque, no que é por muitos considerada a primeira obra de arquitetura moderna brasileira. $\mathrm{O}$ concreto armado, no entanto, só viria a ser utilizado perenemente mais tarde, com o surto industrial ${ }^{181}$.

Há também exemplos de utilização no Brasil de estruturas metálicas, e chapas de cobre e ferro zincado, a partir de meados do século $X I X^{182}$.

\footnotetext{
175 LEMOS, 1989, p. 8.

176 Ibidem, p. 14, 85-86.

${ }^{177}$ Ibidem, p. 9, 13 e 201.

${ }^{178}$ Ibidem, p. 201.

${ }^{179}$ Ibidem, p. 201.

${ }^{180}$ Ibidem, p. 146-148.

${ }^{181}$ Ibidem, p. 18.

182 Ibidem, p. 34 e 50.
} 


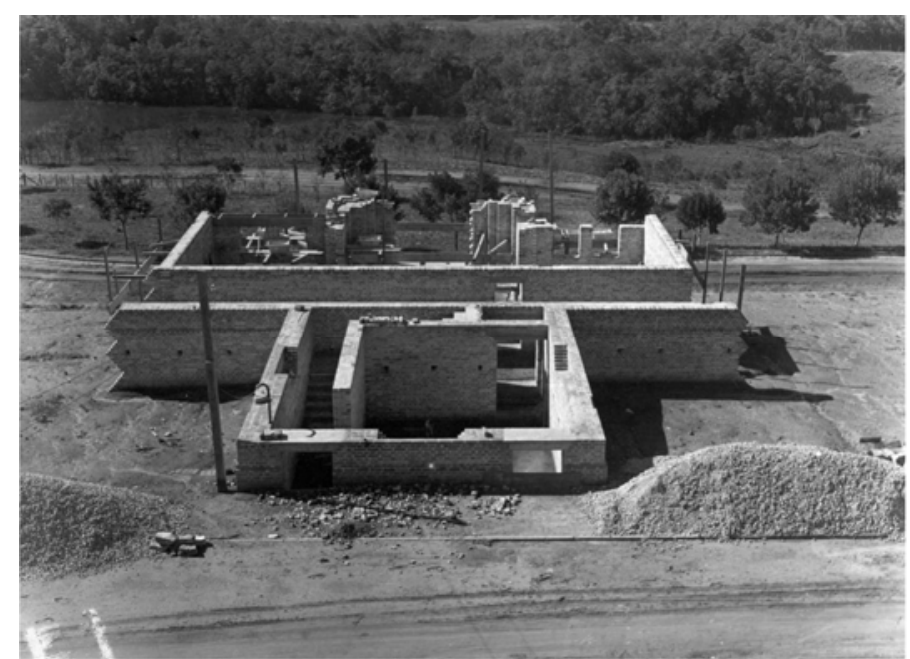

Fig. 42 - Prédio F - Administração. Foto da construção. Anos 1930. Acervo digital do CienTec.

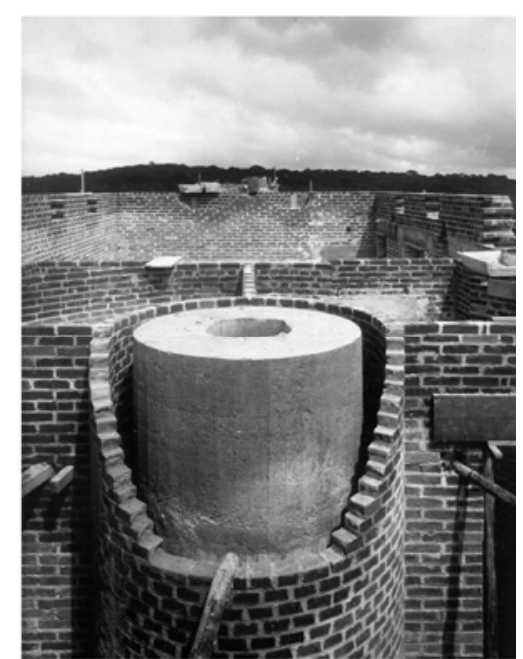

Fig. 43 - Prédio B - Pavilhão Cook. Foto da construção mostrando pilar de concreto para suporte de luneta. Anos 1930. Acervo digital do CienTec.

Do ponto de vista técnico e estilístico, os edifícios do Parque CienTec refletem, em parte, o contexto no qual foram produzidos. As fotos da época da construção, as plantas originais e as prospecções realizadas desde 2001 nos permitem chegar a algumas conclusões.

Os elementos estruturais verticais não foram pilares de concreto, nem metálicos. O sistema geral foi de alvenaria estrutural, com grossas paredes portantes - de 40 a $100 \mathrm{~cm}$, aproximadamente -, intermediadas por cintas de concreto não-armado nas mudanças de pavimento. As fundações também eram de concreto não-armado, completadas por tijolos.

Os projetos originais nos indicam a utilização de colunas de concreto para a sustentação independente das lunetas - o que responde a uma demanda funcional de evitar vibrações que interfeririam com as observações. Também as colunas dos pórticos de entrada são de concreto armado.

Nos sistemas de coberturas e vedação horizontal há três situações observadas: lajes impermeabilizadas; cúpulas (esféricas e semi-cilíndricas) com estrutura de 
madeira e revestimento metálico; e telhados escondidos atrás de platibandas, sobre forro de estuque.

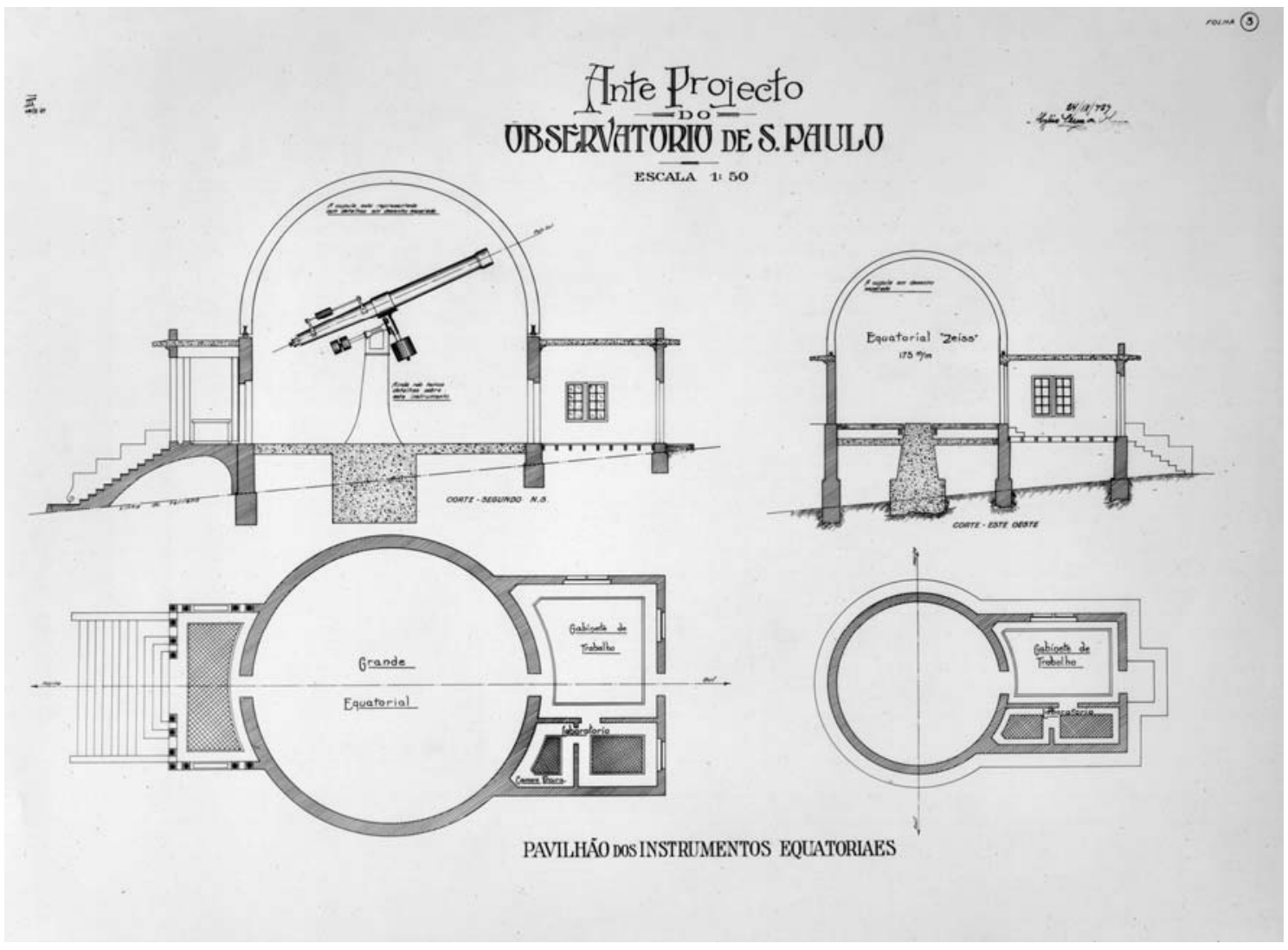

Fig. 44 - Cortes e plantas. Anteprojeto do Pavilhão do Grande Equatorial e estudo descartado (à dir.) dos pavilhões Cook e Photographico. Reparar no pilar central de concreto, para apoio independente dos equipamentos astronômicos e nas lajes de concreto. Oliveira, 1930. Acervo digital do CienTec.

Há foto histórica que mostra a utilização de viga metálica como apoio de vigas de madeira para assoalho e forro. Em outras fotos da época da construção podemos ver o processo de montagem da cúpula menor, a de $4 \mathrm{~m}$ de diâmetro. Ao todo são quatro cúpulas, sendo uma de $10 \mathrm{~m}$ de diâmetro e duas de $6 \mathrm{~m}$. Todas revestidas com chapas metálicas de zinco.

Ao que tudo indica, a mão de obra utilizada não fugiu ao padrão da época, tendo sido composta por construtores italianos ${ }^{183}$.

\footnotetext{
${ }^{183}$ Informações do Prof. Paulo Marques dos Santos, em entrevista concedida ao autor em 16/12/2010. Santos conheceu pessoalmente Oliveira e alguns dos pedreiros que construíram os edifícios e continuaram prestando serviços para a instituição após a inauguração.
} 


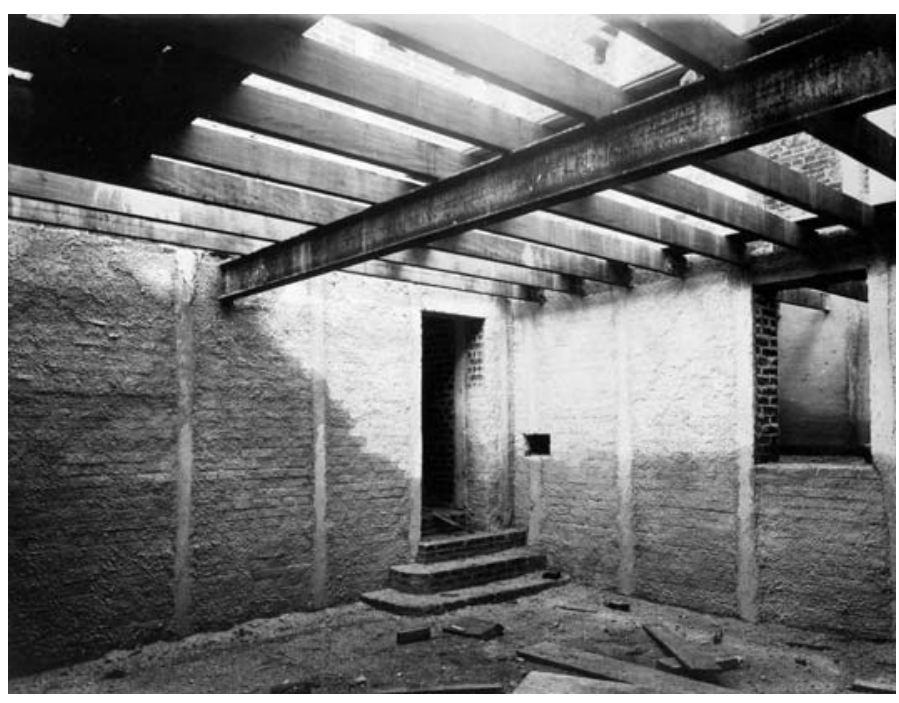

Fig. 45 - Prédio C - Pavilhão

Photographico. Foto da

construção. Anos 1930. Acervo

digital do CienTec.

Na concepção do projeto, Oliveira, aparentemente, seguiu a moda da época. Construiu sob a influência do Art Decó. Entretanto, mesclou características visuais clássicas: notadamente os pórticos com colunas encimadas por capitéis jônicos constituindo pequenas marquises que marcam as entradas da maioria dos prédios, quase sempre com pequenas escadarias para ascender ao nível do térreo - o que dificulta as soluções de acessibilidade. A mistura de estilos também não é novidade: o Ecletismo que vigorou na virada dos séculos XIX para XX utilizava sempre esse recurso.
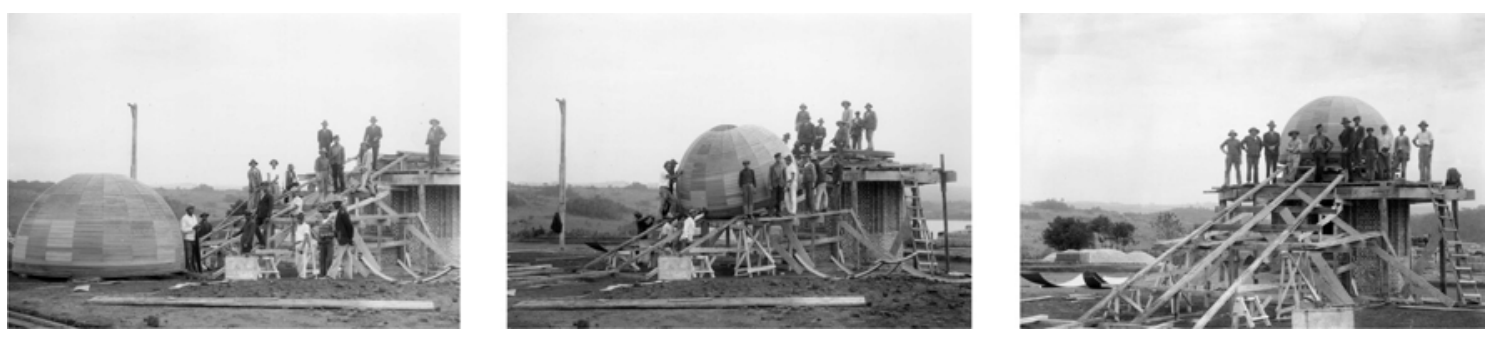

Fig. 46 - Prédio E - Celóstato. A cúpula foi construída no solo e erguida até o local. Fotos da construção. Anos 1930. Acervo digital do CienTec.

Oliveira preocupou-se em arranjar todo o conjunto através de um traçado regulador simétrico, através do qual todos os edifícios técnicos se alinhavam na direção Norte-Sul. 
O Pavilhão do Grande Equatorial ${ }^{184}$, o Celóstato $^{185}$ e o Pavilhão do Serviço Meridiano ${ }^{186}$, se localizavam no eixo central de simetria do conjunto - Norte-Sul -, sendo eles mesmos edifícios absolutamente simétricos. Os Pavilhões $\operatorname{Cook}^{187}$ e Photographico ${ }^{188}$ eram edifícios gêmeos, porém espelhados em relação ao mesmo eixo, estabelecendo a simetria apenas quando tomados em conjunto.

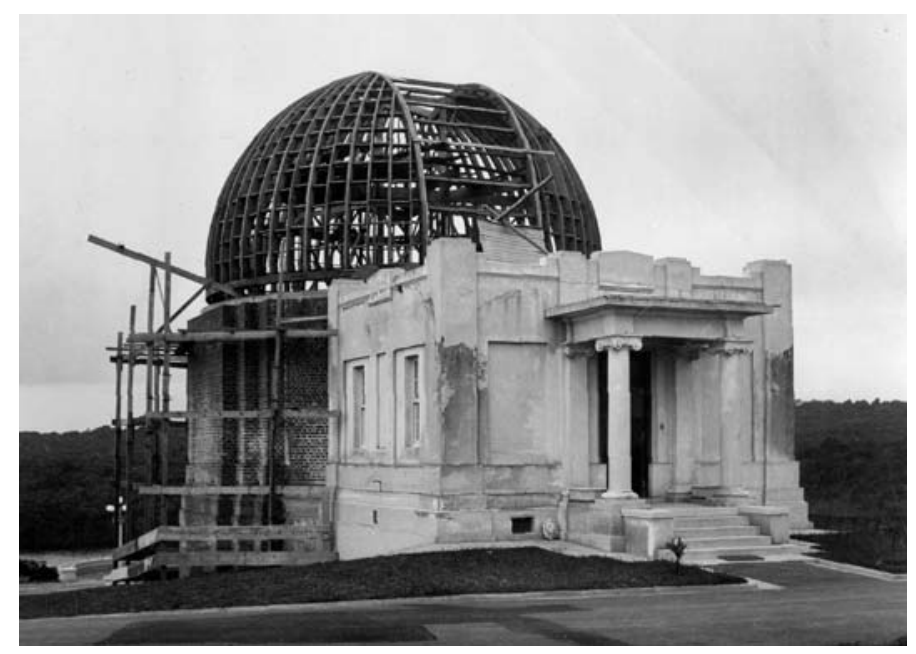

Fig. 47 - Prédio D - Pavilhão do Grande Equatorial. A cúpula, de $10 \mathrm{~m}$ de diâmetro em estrutura de madeira foi construída no local. Reparar no pórtico de entrada com colunas jônicas. Foto da construção. Anos 1930. Acervo digital do CienTec.

Tanto eles quanto o Pavilhão do Serviço Meridiano tinham cúpulas semi-cilíndricas ao centro das quais se localizavam equipamentos astronômicos de aferição que se alinhavam na direção Norte-Sul com as miras meridianas - pequenos obeliscos em formato piramidal, com uma abertura precisamente posicionada. Elas são importantes porque influenciam sobremaneira na implantação, além de terem exigido o desmatamento de uma extensa faixa para permitir a visada entre o Pavilhão das Miras e as miras mais distantes, ao Sul.

A localização do conjunto do observatório de São Paulo, fora dos limites da cidade na época, determinou a necessidade da construção de residências para a equipe: a Residência do Diretor, do Zelador e do Empregado, inseridos no traçado regulador e

\footnotetext{
${ }^{184}$ Edifício $E$ na notação original de Oliveira, 04 na numeração atual.

${ }^{185}$ Edifício $D$ na notação original, 23 na numeração atual. O celóstato do IAG nunca chegou a operar. Sua lógica de funcionamento será explicada mais adiante, quando for mencionada a Torre Einstein, de Mendelsohn.

${ }^{186}$ Edifício A / 15.

${ }^{187}$ Edifício C / 09, onde até hoje se encontra uma centenária luneta Zeiss, utilizada nos tempos do Instituto como instrumento de pesquisa, e atualmente como equipamento educacional.

${ }^{188}$ Edifício B / 08. A luneta Grubb anteriormente aqui instalada foi doada ao CDCC da USP - São Carlos, onde se encontra até os dias atuais.
} 
com linguagem formal semelhante, a menos das cúpulas que indicavam a utilização científica dos demais prédios.
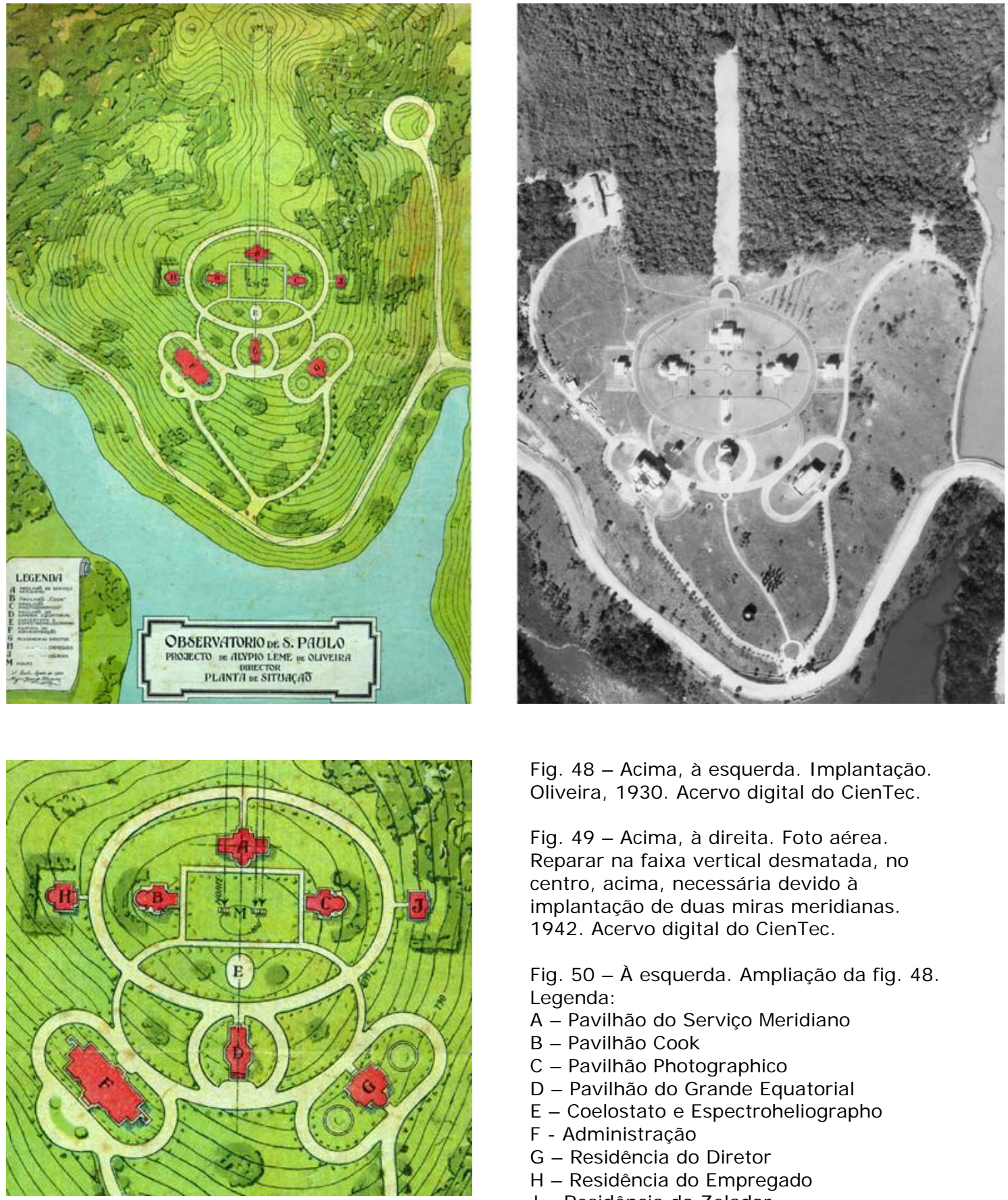

Fig. 48 - Acima, à esquerda. Implantação. Oliveira, 1930. Acervo digital do CienTec.

Fig. 49 - Acima, à direita. Foto aérea. Reparar na faixa vertical desmatada, no centro, acima, necessária devido à implantação de duas miras meridianas. 1942. Acervo digital do CienTec.

Fig. 50 - À esquerda. Ampliação da fig. 48. Legenda:

A - Pavilhão do Serviço Meridiano

B - Pavilhão Cook

C - Pavilhão Photographico

D - Pavilhão do Grande Equatorial

E - Coelostato e Espectroheliographo

F - Administração

G - Residência do Diretor

H - Residência do Empregado

J - Residência do Zelador

Há dois conjuntos da década de 1920 que são interessantes para comparação com os edifícios do CienTec: o conjunto do Observatório Nacional, no Rio de Janeiro, e a Torre Einstein, na Alemanha. 
Em 1920 Erick Mendelsohn projetou a Torre Einstein, um observatório e instituto astrofísico próximo a Potsdam. Foi o primeiro projeto do arquiteto a receber atenção, e denotava algumas das características formais típicas de sua arquitetura: "volumes compostos dinamicamente, aerodinâmicos, faixas horizontais nas paredes, janelas em banda e esquinas arredondadas" ${ }^{189}$. A cúpula abrigava um celóstato, que

refletia na vertical raios de fontes luminosas cósmicas que descem pela torre até o laboratório subterrâneo. Aí são defletidos por um espelho com um ângulo de $45^{\circ}$ e, assim, orientados para instrumentos onde se gera um espectro e se fazem medições comparadas. ${ }^{190}$
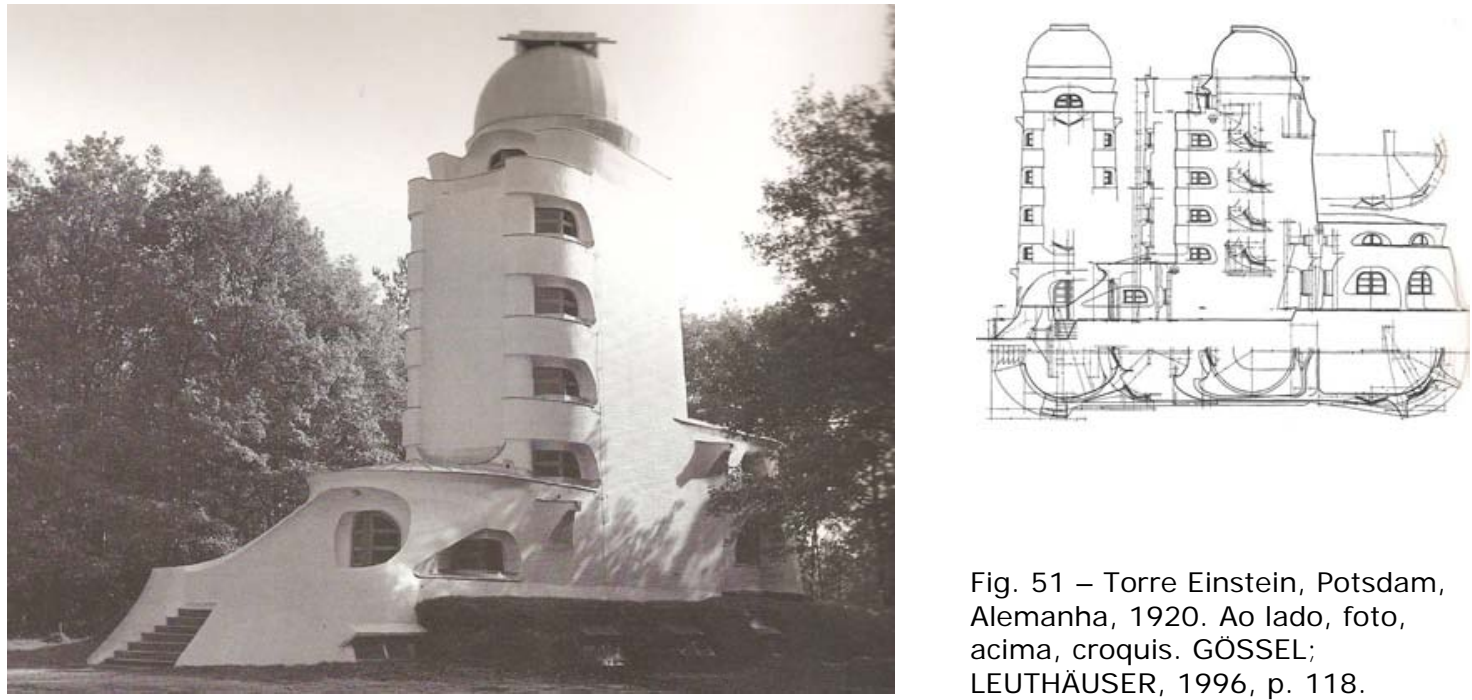

Fig. 51 - Torre Einstein, Potsdam, Alemanha, 1920. Ao lado, foto, acima, croquis. GÖSSEL; LEUTHÄUSER, 1996, p. 118.

O objetivo principal do edifício era realizar estudos para a comprovação da teoria da relatividade de Einstein. "Embora a organização interna do seu complexo laboratorial fosse determinada por requisitos científicos, Mendelsohn teve inteira liberdade no seu desenho de arquitetura da que soube tirar vantagem" ${ }^{191}$.

Segundo Jordan, "Gaudi tinha explorado todas as liberdades que o betão [concreto] armado proporcionava, mas à medida que as curvas sinuosas da Arte Nova [Art Noveau] se foram desvanecendo, essa liberdade adquiriu uma nova feição; o

\footnotetext{
189 GÖSSEL; LEUTHÄUSER, 1996, p. 409.

190 Ibidem, p. 118.

191 Ibidem, p. 122.
} 
Expressionismo" 192, no qual se encaixava o trabalho de Mendelsohn. Ele foi, inclusive, amigo de artistas do grupo expressionista Der Blaue Reiter, como Paul Klee e Wassili Kandinsky ${ }^{193}$.

É interessante, entretanto, que a torre é um edifício construído com tijolos, visto que sua moldagem completa em concreto foi abandonada por ser demasiadamente difícil e cara ${ }^{194}$ - o que nos faz lembrar a primeira residência modernista de Warchavchik, cujo telhado convencional em duas águas era escondido pela platibanda para fazer-se passar por laje plana.

A situação do Museu de Astronomia e Ciências Afins (MAST) é muito mais semelhante à do CienTec: ambos passaram a ocupar o sítio originalmente arranjado para instituições de pesquisa científica, com topografia semelhante, e apenas uma década de diferença entre a construção de cada um.

O MAST foi criado em $1985^{195}$. Seus edifícios originalmente pertenciam ao Observatório Nacional, situado no Morro de São Januário, no Rio de Janeiro. O conjunto formado por 16 edifícios e concluído em 1921 "foi tombado pelo Instituto do Patrimônio Histórico e Artístico Nacional (Iphan) em 1986 e pelo Instituto Estadual do Patrimônio Cultural (Inepac) em 1987" ${ }^{196}$. Dentre esses edifícios estão “os três pavilhões das lunetas equatoriais, exemplos típicos da Arquitetura e Engenharia para a Astronomia" ${ }^{197}$, dos quais apenas dois estão sob a guarda do MAST.

O conjunto arquitetônico do MAST é formado por edificações que testemunham algumas das transformações tecnológicas pelas quais passou a Arquitetura no século XIX, marcada pela introdução de novos materiais surgidos a partir da Revolução Industrial e que teve forte meio de expressão

\footnotetext{
192 JORDAN, 1979, p. 321.

193 GÖSSEL; LEUTHÄUSER, 1996, p. 408.

194 JORDAN, 1979, p. 321; GÖSSEL; LEUTHÄUSER, 1996, p. 122.

${ }^{195}$ MARANDINO, 2008, p. 11.

${ }^{196}$ GRANATO; BRITO; SUZUKI, 2005, p. 273.

${ }^{197}$ Ibidem, p. 273.
} 
nos exemplares ecléticos dos primeiros anos do século $X X$. [...] Suas estruturas refletem uma conjugação de tendências conciliando técnicas construtivas inovadoras, baseadas na potencialidade de materiais como o aço e o cimento, sem abandonar, no entanto, procedimentos tradicionais. Seus edifícios incorporaram toda sorte de materiais importados, inclusive componentes inteiros encomendados de fabricantes estrangeiros ${ }^{198}$.

Uma parceria com a fundação Vitae permitiu que fosse realizado um projeto piloto de restauro de um dos edifícios, incluindo a cúpula metálica móvel (com estrutura primária metálica e secundária em madeira ${ }^{199}$ ) e o instrumento científico ${ }^{200}$ : o “Pavilhão da Luneta Equatorial de $32 \mathrm{~cm}$, projeto do engenheiro Mário Rodrigues de Souza, datado de 1914" 201.

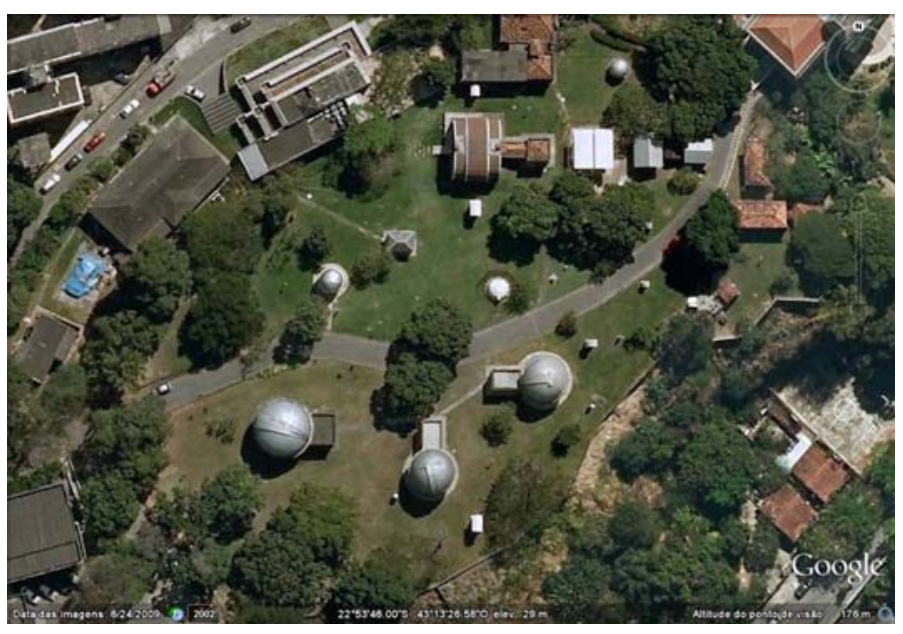

Fig. 52 - Foto aérea, permitindo entender a implantação do MAST. Google, 2009.

A implantação dos três pavilhões das lunetas, como no caso do CienTec, se alinhou à direção Norte-Sul. Segundo Granato, Brito e Suzuki, eles "formam um conjunto que se irmana em sua linguagem arquitetônica: mesma ordenação e composição dos espaços, mesmas proporções gerais, adornos externos e materiais de acabamento semelhantes" 202. Ambas as topografias eram acidentadas, constituindo-se em colinas, impelindo os autores dos projetos - tanto do

\footnotetext{
${ }^{198}$ GRANATO; BRITO; SUZUKI, 2005, p. 278.

199 Ibidem, p. 278.

${ }^{200}$ Ibidem, p. 273.

${ }^{201}$ Ibidem, p. 279.

202 Ibidem, p. 279.
} 
Observatório carioca quanto do paulista - a localizarem os edifícios nas cotas mais altas, com o objetivo de proporcionarem boas visadas para os seus instrumentos.

A planta do pavilhão do MAST se constitui em "um corpo principal [...] circular, em que ficam instalados os instrumentos, alteados do chão por um porão habitável, e um vestíbulo [...] retangular que the serve de acesso" ${ }^{203}$. Embora o estudo preliminar de Oliveira (ver fig. 44, p. 188) tivesse planta quase idêntica, no projeto definitivo ele aumentou a quantidade de ambientes, sofisticando a volumetria do edifício. Outra diferença marcante é a escada externa do edifício do CienTec, que também dinamiza seu exterior.

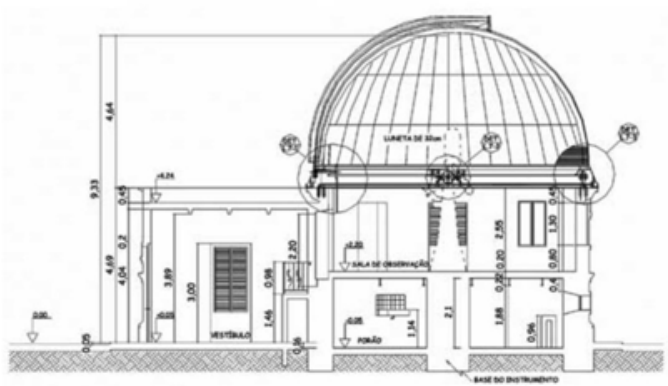

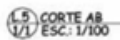

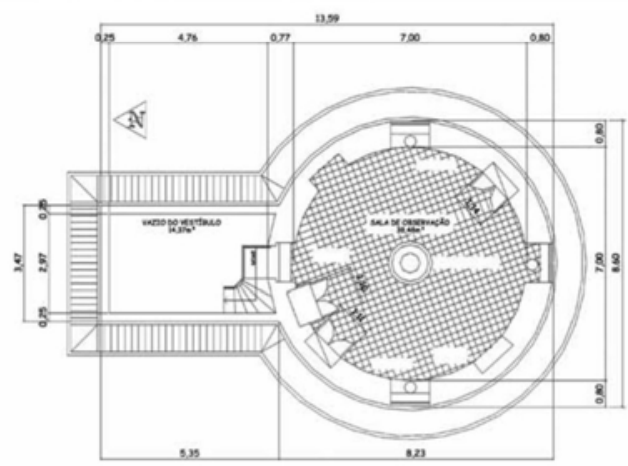

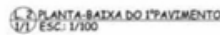

Fig. 53 - MAST. Pavilhão da Luneta Equatorial de $32 \mathrm{~cm}$. Corte e planta (levantamento as-built). GRANATO; BRITO; SUZUKI, 2005, p. 280.

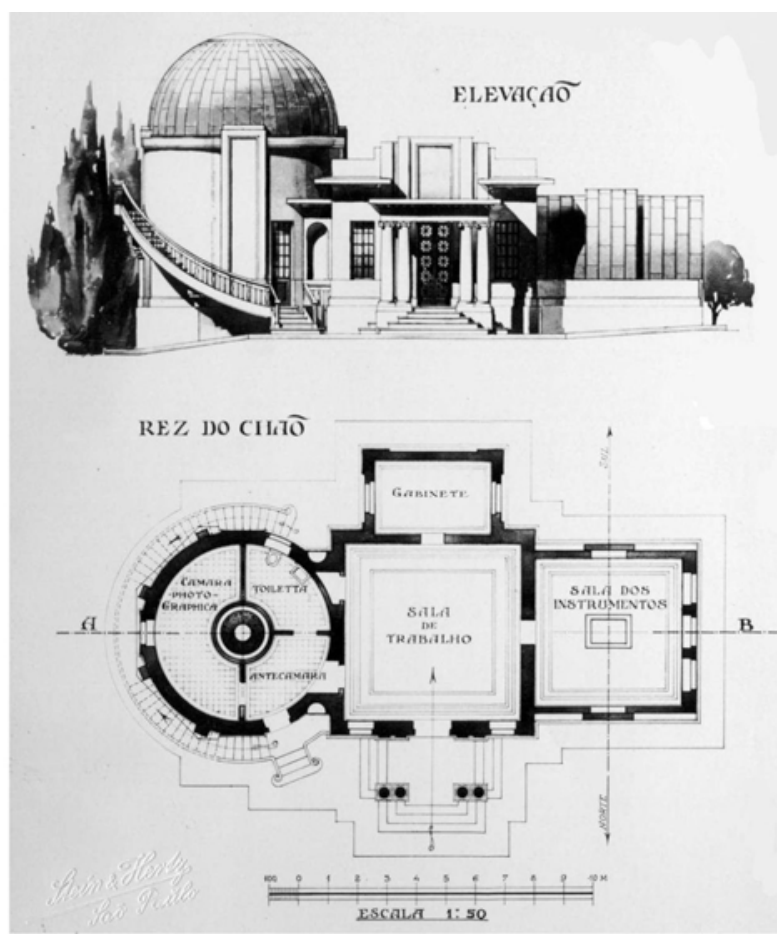

Fig. 54 - CienTec. Pavilhão Cook. Elevação e planta (projeto original). Acervo digital do CienTec.

Há grandes semelhanças com relação à estrutura. No caso do MAST “composta de muros autoportantes [...] de tijolo maciço [...] [ou] blocos de granito não aparelhados" 204 , com "fundação contínua de pedra britada e concreto" 205 e "lajes

\footnotetext{
${ }^{203}$ GRANATO; BRITO; SUZUKI, 2005, p. 279.

${ }^{204}$ Ibidem, p. 282.
} 
[...] de concreto armado com tela deployée, apoiadas em vigas metálicas em duplo 'T' e sustentadas nas paredes perimetrais" 206.

Percebe-se, pelo texto de Granato, Brito e Suzuki, o cuidado com que foi realizado o restauro do Pavilhão do $\mathrm{MAST}^{207}$. Entretanto, não sendo o foco do nosso estudo, vamos nos concentrar nas relações que podem ser feitas com a arquitetura do CienTec.

A implantação dos edifícios do MAST atendeu ao requisito funcional de alinhar os edifícios técnicos com a linha Norte-Sul, mas sua disposição parece aleatória. Obviamente não há nenhuma obrigação em utilizar um traçado regulador ou explorar, nesse traçado e nos edifícios, a simetria - um valor associado ao clássico. Essa liberdade na implantação, assim como o despojamento dos edifícios do Observatório Nacional poderia até mesmo ser considerados um avanço rumo ao modernismo. Entretanto, não é o que parece - e os detalhes existentes nos prédios do MAST simplesmente não são tão bem arranjados quanto os do CienTec.

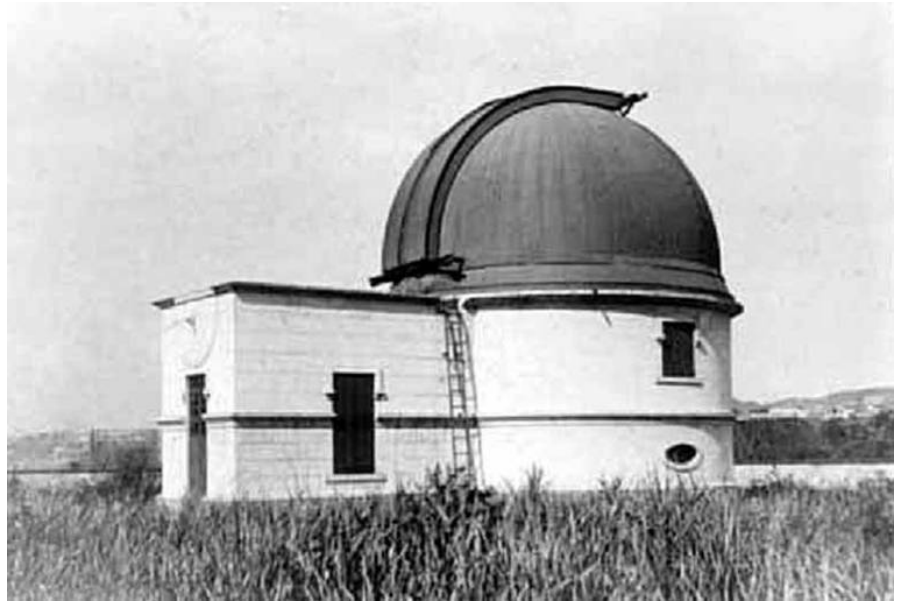

Fig. 55 - MAST. Pavilhão da Luneta Equatorial de $32 \mathrm{~cm}$ após sua construção, 1920. Acervo do MAST. GRANATO; BRITO; SUZUKI, 2005, p. 281.

Oliveira não era arquiteto, mas engenheiro e geógrafo, não havendo registro de outra incursão no ramo de projeto arquitetônico além desta, para a concretização do observatório do qual ele mesmo era o diretor. Também não estava em sintonia

\footnotetext{
${ }^{205}$ GRANATO; BRITO; SUZUKI, 2005, p. 282.

206 Ibidem, p. 282.

${ }^{207}$ Ibidem, p. 283-302.
} 
com a vanguarda arquitetônica brasileira, que já buscava afirmar no país o modernismo.

Entretanto, seus desenhos originais - nanquins e aquarelas - são muito bonitos, e o resultado obtido nos edifícios originais nos parece singular, harmonioso e refinado, além de os mesmos atenderem tecnicamente às funções para as quais foram projetados. Não encontramos edifícios com essa linguagem em outros lugares. O efeito geral do Observatório de São Paulo nos parece muito superior e mais significativo, por exemplo, do que o do Observatório Nacional - e, também, claro, na mesma proporção, muito menos audacioso ou integrado com a evolução da arquitetura mundial do que a Torre Einstein.

Uma nova instituição

Assim que foi criado o Parque CienTec, iniciou-se, com o apoio da Secretaria Estadual de Ciência e Tecnologia e da Fundação Vitae, o projeto conceitual e arquitetônico da nova instituição, incluindo o restauro e reconversão de parte dos edifícios existentes e a construção de um novo, para possibilitar exposições de maiores dimensões.

A Vitae providenciou a vinda de especialistas estrangeiros como consultores: Jorge Wagensberg, do Museo de la Ciencia, de Barcelona; Ronen Mir, do SciTech Handson Museum de Aurora, Illinois, EUA, e do Clore Garden of Science, em Israel; e David Ellis, do Boston's Museum of Science.

O Governo Estadual financiou o projeto arquitetônico, desenvolvido através do trabalho em equipe de diversos destacados arquitetos brasileiros: Giancarlo Gasperini, Roberto Aflalo Filho, José Armênio Brito Cruz, Paulo Mendes da Rocha, Siegbert Zanettini, Paulo Bruna e Nestor Goulart Reis Filho. A reconversão e o restauro dos edifícios históricos ficou a cargo dos dois últimos. 
Os edifícios cuja reconversão trará maior impacto para o CienTec são o Pavilhão do Grande Equatorial, a Residência do Empregado e o Pavilhão do Serviço Meridiano. O primeiro se transforma em planetário, o segundo em auditório, e o terceiro, em ambiente com café e loja.

Atualmente se encontra em andamento o restauro do antigo Pavilhão do Grande Equatorial (Prédio 04), que se torna um planetário digital totalmente acessível e com capacidade para 50 pessoas. As obras se iniciaram em fins de 2006 , com prazo de oito meses. Entretanto, após diversos atrasos e a necessidade de rompimento de contrato e realização de uma segunda licitação, o prazo de conclusão se estendeu para 2011.
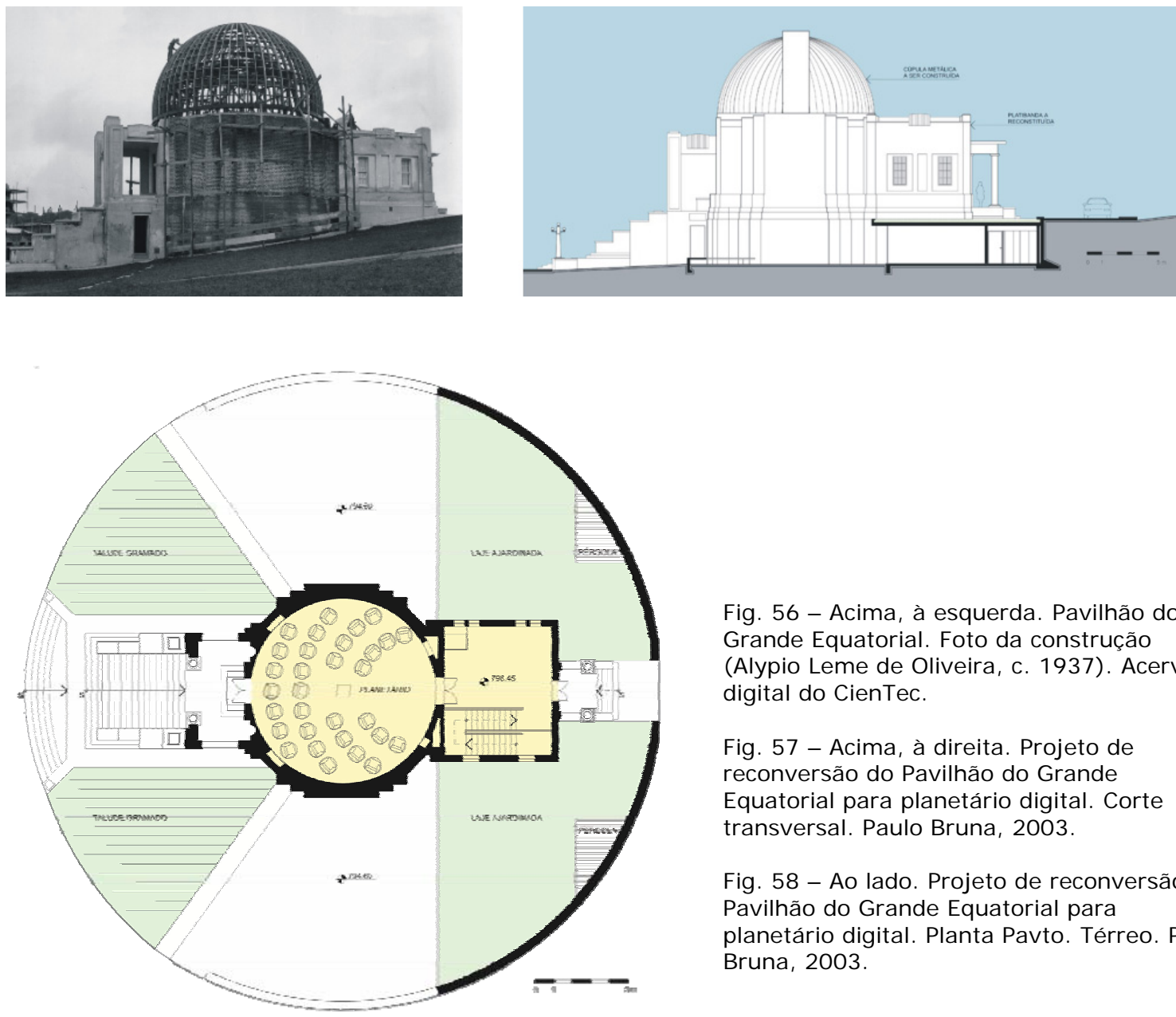

Fig. 56 - Acima, à esquerda. Pavilhão do Grande Equatorial. Foto da construção (Alypio Leme de Oliveira, c. 1937). Acervo digital do CienTec.

Fig. 57 - Acima, à direita. Projeto de reconversão do Pavilhão do Grande Equatorial para planetário digital. Corte transversal. Paulo Bruna, 2003.

Fig. 58 - Ao lado. Projeto de reconversão do Pavilhão do Grande Equatorial para planetário digital. Planta Pavto. Térreo. Paulo Bruna, 2003. 
O edifício foi usado pelo IAG como laboratório de paleomagnetismo. Posteriormente o Parque CienTec ali abrigou a exposição de Geofísica até 2005, quando sua equipe de arquitetura e engenharia iniciou prospecções no piso da sala principal circular. É relevante que o início do processo de recuperação arquitetônica se dê justamente nesse edifício, pois ele foi um dos mais desfigurados, tendo sua cobertura totalmente modificada.

O edifício é composto por dois volumes principais: um de planta circular e outro de planta retangular. Originalmente o corpo retangular apresentava laje plana com platibanda, e o circular era coberto por um domo em chapas metálicas sobre estrutura de madeira. Por volta da década de 1970, todas as platibandas foram removidas. Sobre a laje retangular se instalou um telhado de fibrocimento em duas águas. O corpo circular teve sua estrutura de madeira demolida e substituída por um telhado de seis águas em fibrocimento, com um pilar central de madeira. Além disso, outras duas adições espúrias foram realizadas: uma escada helicoidal em concreto pré-fabricado e um abrigo de materiais.

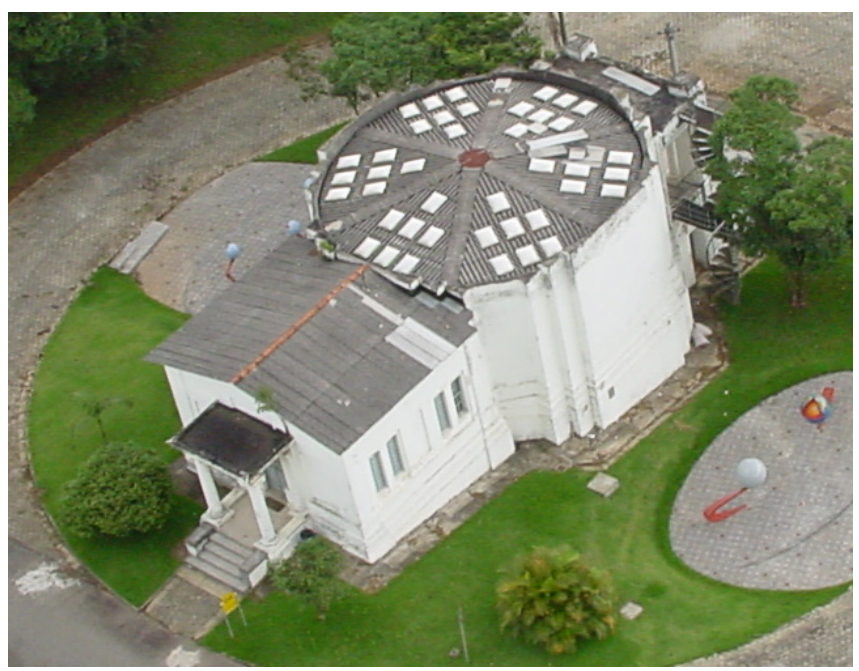

Fig. 59 - Prédio D - Pavilhão do Grande Equatoria. Foto aérea mostrando as alterações realizadas décadas antes em sua cobertura e a escada helicoidal de concreto (canto superior direito). 2004. Acervo digital do CienTec.

O projeto de restauro e reconversão indica a recomposição da parte externa do edifício de acordo com as plantas do projeto original. Entretanto, a nova destinação do espaço requereu uma intervenção importante nos ambientes internos, com adição de áreas no subsolo para acolher principalmente os serviços: foyer, 
sanitários, saleta para os equipamentos, escada e plataforma vertical para cadeirantes e pessoas com dificuldade de locomoção. O acesso ao planetário se faz por esse pavimento. O foyer poderá abrigar também pequenas exposições com temas relacionados à apresentação do Planetário.

“Com tal solução, ficam totalmente preservadas as formas externas do edifício, inclusive os terraços de acesso, com seus pisos, portas e janelas, bem como as visuais hoje possíveis" 208.

O equipamento adquirido permite não apenas o uso como planetário, mas também a projeção de outros conteúdos, tanto astronômicos como de qualquer outro tema que se adapte a projeções semi-esféricas.

\section{Novo Edifício}

Os espaços dos edifícios originais apresentam salas com razoável pé-direito (em alguns casos, próximo de $4 \mathrm{~m}$ ), mas reduzidas proporções: a maior sala do conjunto apresenta área de apenas seis $\mathrm{x}$ oito $\mathrm{m}^{2}$. Há algumas edificações nãooriginais, com salas de dimensões semelhantes ou menores, pés direitos baixos (por volta de $2,50 \mathrm{~m}$ ) e estrutura parcialmente dependente da alvenaria - o que dificulta a ampliação das salas pela demolição das paredes. Ou seja, são espaços inadequados para exposições.

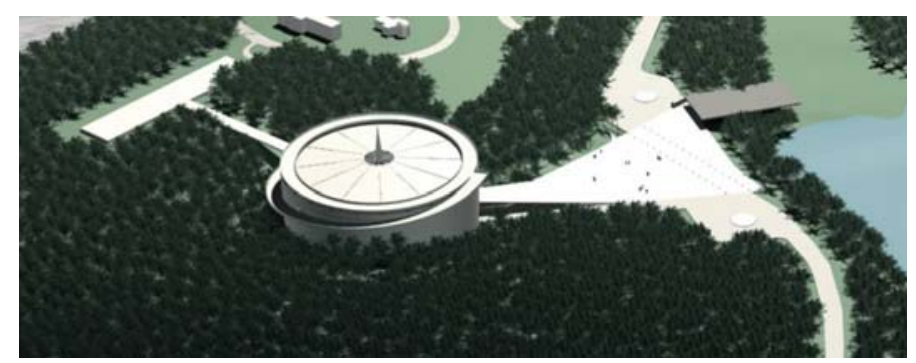

Fig. 60 - Novo edifício. Maquete eletrônica. 2003. Acervo digital do CienTec.

\footnotetext{
${ }^{208}$ MANTOVANI; MASSAMBANI, 2004b, p. 54. Textos de Nestor Goulart Reis.
} 
Em vista disso, além da reconversão e restauro dos dez edifícios originais, há a previsão de construção de um novo edifício, com dimensões espaciais que possibilitem a realização de exposições permanentes e temporárias de maior porte, seminários e congressos em auditório para 400 pessoas, cursos, etc., além de prever áreas técnicas, de guarda e manutenção de acervo. O projeto básico desse edifício também já existe, com área construída de cerca de 25 mil metros quadrados, e projeção de 10 mil metros quadrados (sendo 6,5 mil do edifício e 3,5 mil da praça de ligação com a entrada do Zoológico). Não há previsão para início de obras.

\section{Situação Atual}

Oficialmente criado em dezembro de 2001, o Parque CienTec abriu suas portas ao público pouco menos de um ano depois, em setembro de 2002, contando com algumas atividades: Exposição de Matemática (gêmea daquela existente na Estação Ciência e baseada em exposição do Cité des Sciences et de I'Industrie, Parc de la Villette, Paris, França); Alameda do Sistema Solar (conjunto de esculturas artísticas que o representam); Exposição de Geofísica (que trata de temas como vulcanismo, prospecção de minérios, terremotos, etc.); Luneta Zeiss (centenária luneta que era utilizada em pesquisa astronômica na primeira metade do século XX); Meteorologia (composta por equipamentos até hoje operacionais para realização de medições meteorológicas).

Principalmente em virtude do apoio da Fundação Vitae ${ }^{209}$, novas atividades - em sua maioria interativas - foram implementadas nos anos seguintes: Exposição de Física (Mecânica, Óptica, Acústica, Eletricidade), com equipamentos internos e ao ar livre; Exposição de Energias Alternativas; Nave Mario Schenberg e Gruta Digital 3D.

\footnotetext{
${ }^{209}$ O Parque CienTec recebeu da Vitae, no decorrer dos anos de 2005 e 2006, pouco menos de quatro milhões de reais para a implantação das atividades. A Vitae, durante quase duas décadas, apoiou a implantação e desenvolvimento de museus e centros de ciência no país (IANINI, 2007).
} 
Vitae.

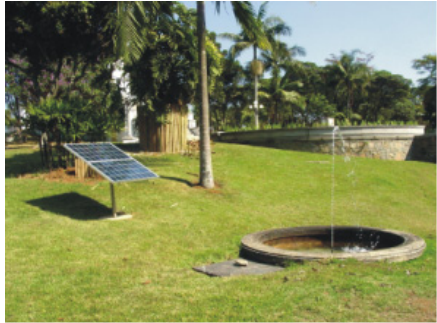

Fig. 61 - Fonte original recuperada utilizando energia solar (célula fotovoltaica). 2007. Acervo digital do CienTec.

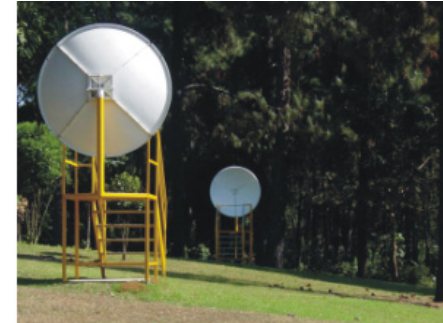

Fig. 62 - Conchas acústicas. Dois visitantes podem se comunicar, falando em tom baixo, cada um no foco de uma das conchas. 2007. Acervo digital do CienTec.

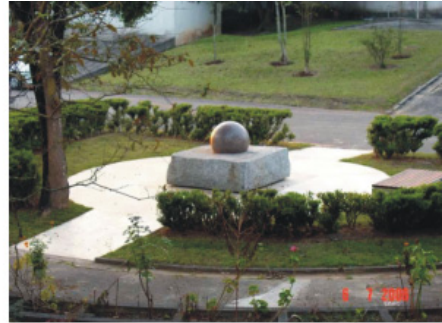

Fig. 63 - Esfera de granito. Uma esfera de $600 \mathrm{~kg}$ é facilmente movida com o auxílio de um filete d'água. 2007. Acervo digital do CienTec.

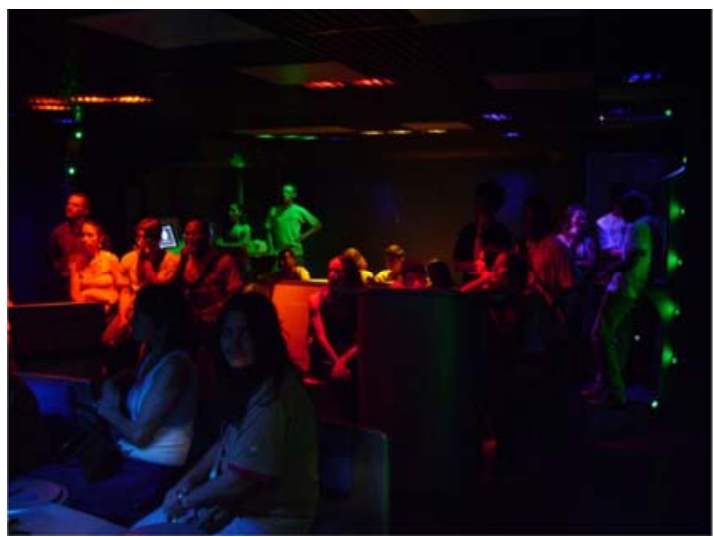

Fig. 64 - Nave Mario Schenberg. Sala de comando. 2007. Acervo digital do CienTec.

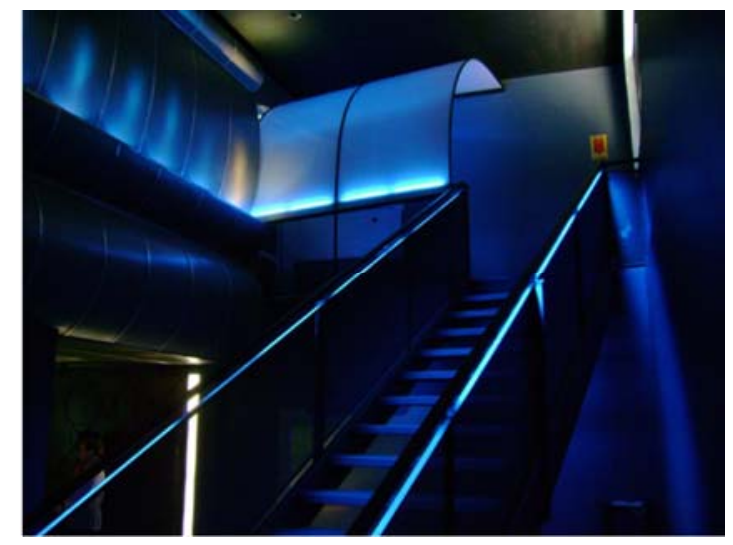

Fig. 65 - Nave Mario Schenberg. Escada de acesso. 2007. Acervo digital do CienTec.

A partir de 2006 o Parque CienTec iniciou o projeto de itinerância, no qual as atividades se dão nas próprias sedes das instituições interessadas - em sua maioria escolas -, com a presença dos educadores e monitores do CienTec munidos dos equipamentos interativos móveis.

Atualmente o público no local é de cerca de quinze mil visitantes anuais, que se complementa com cerca de quarenta mil visitantes nas atividades de itinerância. 


\subsubsection{Estação Ciência (USP), São Paulo, SP}

Introdução. Origens e contexto histórico.

Segundo Crodowaldo Pavan, presidente do Conselho Nacional de Desenvolvimento Científico e Tecnológico (CNPq) na época da implantação e inauguração da Estação Ciência, a idéia de implantar um centro de ciências tinha surgido no início da década de 1970, quando foi fundada a Academia de Ciências do Estado de São Paulo, e teve como entusiasmados defensores importantes nomes da ciência brasileira como J osé Reis ${ }^{210}$ e Sérgio Mascarenhas ${ }^{211}$.

O Brasil vivia um momento político de esperança renovada na democracia. A primeira eleição direta para cargos executivos depois da ditadura militar ocorreu em 1982 (governadores), e a mobilização para as eleições presidenciais diretas pouco tempo depois, em 1984. A pressão popular não foi suficiente, e as eleições se deram como previsto pela constituição vigente, de forma indireta. Entretanto, foi eleito o preferido do povo, Tancredo Neves, tendo J osé Sarney como vice.

Com a morte prematura de Tancredo, Sarney assumiu e se tornou o primeiro presidente civil em vinte anos, tendo cumprido seu mandato integralmente. 0 ambiente de redescoberta da liberdade de expressão era propício para novas iniciativas de divulgação cultural.

Dentro desse espírito, na década de 1980 foram criados alguns dos mais importantes museus e centros de ciência no Brasil: o Museu de Astronomia e Ciências Afins (MAST), no Rio de Janeiro, em 1985; a Estação Ciência, em São

\footnotetext{
${ }^{210}$ José Reis (1907 - 2002) - jornalista, médico, cientista e divulgador científico. Participou da fundação da Sociedade Brasileira para o Progresso da Ciência (SBPC). Foi Diretor de Redação da Folha de São Paulo por cinco anos (1962-1967). Recebeu diversos prêmios durante sua carreira.

${ }^{211}$ Sérgio Mascarenhas (n. 1928) - físico e pesquisador. Fundador do Instituto de Física e Química da USP de São Carlos e da Universidade Federal de São Carlos. Idealizador da Academia de Ciências do Estado de São Paulo. Participou de instituições como o CNPq, o Instituto de Pesquisas Energéticas e Nucleares (IPEN), a Empresa Brasileira de Pesquisa Agropecuária (EMBRAPA), e o Instituto de Estudos Avançados da USP de São Carlos, entre outras.
} 
Paulo, em 1986; e o Museu Dinâmico de Ciências da Unicamp, em 1987. Essas instituições "desempenharam papel inovador ao apresentarem exposições interativas e ao adotarem princípios pedagógicos construtivistas" 212.

A Estação Ciência, portanto, não foi a primeira dessas instituições, tendo sido aberta após o MAST. Seu projeto (não-arquitetônico) foi elaborado com a participação de um grupo de 60 pessoas do CNPq, que contaram com a colaboração de universidades, diversos órgãos governamentais e empresas: USP; UNICAMP; Universidade Estadual de São Carlos; Instituto Butantã; Funbec (Fundação Brasileira para o Desenvolvimento do Ensino de Ciências); e Ibec (Instituto Brasileiro de Cultura e Ciência); empresas privadas e estatais; entre outras.

A Estação Ciência está sob a responsabilidade da USP desde 1990. No ano de sua inauguração a nova instituição teria o objetivo de "estimular a realização científica nos jovens mediante contato com experimentos científicos" ${ }^{213}$. Passados vinte anos, sua missão foi mantida na essência: “Popularizar a ciência e a tecnologia para jovens e adultos por meio de experimentos lúdicos interativos, atividades afins e eventos, promovendo a apropriação do método científico, o conhecimento multidisciplinar e a cultura" ${ }^{214}$. É composta por exposições relacionadas às diversas áreas de conhecimentos científicos, complementadas por palestras e outras atividades de divulgação.

Entretanto, comparando-se os textos de 1987 e de 2007, verifica-se que o primeiro se referia apenas a jovens, e o segundo a "jovens e adultos". A discussão sobre o público alvo interferiu inclusive na escolha do nome da instituição, originalmente "Centro de Ciências para a Juventude" e depois "Estação Ciência", criado pelo publicitário Washington Olivetto, assim como seu logotipo. Entendeu-se que seu nome não deveria sugerir uma limitação ao tipo de público visitante, pois a atração

\footnotetext{
${ }^{212}$ MARANDINO, 2008, p. 11

${ }^{213}$ SÃO PAULO, 1987, p. 5.

${ }^{214}$ ESTAÇÃO, 2007.
} 
de um público diversificado estava presente já nas discussões iniciais para a implantação da Estação Ciência ${ }^{215}$. O texto da missão de 2007 torna claro o que já se discutia antes de 1987.

De qualquer forma, os estudantes de primeiro e segundo graus (ou ensino fundamental e médio), foram sempre considerados com particular atenção, em especial aqueles provenientes da rede oficial de ensino. É uma ênfase pertinente, visto que as escolas públicas estão, em geral, pior equipadas que as particulares, e, seus alunos são bastante carentes de formação complementar.

Nely Bacellar, primeira coordenadora da Estação Ciência, afirma que durante o planejamento inicial objetivava-se atingir um público anual de meio milhão de estudantes ${ }^{216}$.

Em 1987 a previsão da capacidade de suporte para o espaço inicial (seis módulos) era de 800 visitantes / dia. Considerando as visitas em cinco dos sete dias da semana resulta um total potencial de 200 mil visitantes por ano.

Em 1998 a visitação anual estava estável na faixa de 200 mil pessoas. Segundo Ernst Hamburger, diretor da Estação Ciência à época, “a procura excede a capacidade de atendimento" ${ }^{217}$, o que significaria que com um maior espaço a visitação também seria maior. A área ocupada em 1998 já compreendia todos os 12 módulos do galpão, totalizando pouco menos de cinco mil metros quadrados.

Em 2005 a visitação declarada foi de 393.856 pessoas, mas esse número inclui a chamada "visitação virtual" ao site da instituição, estimada em 120.000. Descontando-se esse número, temos 273.856 visitantes, ainda distante da meta projetada em $1986 \ldots$

\footnotetext{
${ }^{215}$ FEDERSONI, 1998.

${ }^{216}$ BACELLAR, 1998.

${ }^{217}$ HAMBURGER, 1998, p. 178.
} 
Localização

A Estação Ciência se situa no bairro da Lapa, em São Paulo. O prédio ocupado pela Estação Ciência (A) faz parte de um conjunto edificado ${ }^{218}$ que inclui também o prédio contíguo (B), construído em época posterior. As duas edificações pertenciam ao Fundo Social de Solidariedade do Governo Estadual quando da criação da museu. Uma foi cedida, a outra permaneceu sob a tutela do Governo, e é ocupada pela Estação Especial da Lapa:

Espaço público voltado, prioritariamente, às pessoas com deficiência $[\ldots]$, [que] oferece cursos de iniciação profissional, oficinas culturais, programas de esporte adaptado e equoterapia, que possibilitam inclusão social e melhor qualidade de vida ${ }^{219}$.

A edificação $A$, que hoje abriga a Estação Ciência e foi construída originalmente para uma indústria têxtil, quase foi destruída por um incêndio em 1936. Foi reconstruída logo depois, e utilizada com diversos fins diferentes do original ao longo dos anos. No final de 1985 o Condephaat deu início ao estudo para tombamento, o que impede demolições ou alterações sem prévia consulta ao órgão.

No espaço em que até a década de 1960 funcionava a garagem de bondes, foi concluído em 2004 o Terminal de Ônibus da Lapa (D) ${ }^{220}$, ao lado da Praça Miguel dell'Erba (F), e da Estação Lapa da CPTM (E). Em frente ao Terminal fica o Mercado da Lapa (I), construído em $1954^{221}$.

\footnotetext{
${ }^{218}$ Ver fig. 66, na próxima página.

${ }^{219}$ Portal de serviços do Governo do Estado de São Paulo.

${ }^{220}$ ARCOWEB, 2007. Projeto de 2002, do Núcleo de Arquitetura.

${ }^{221}$ SAMPAART, 2007.
} 


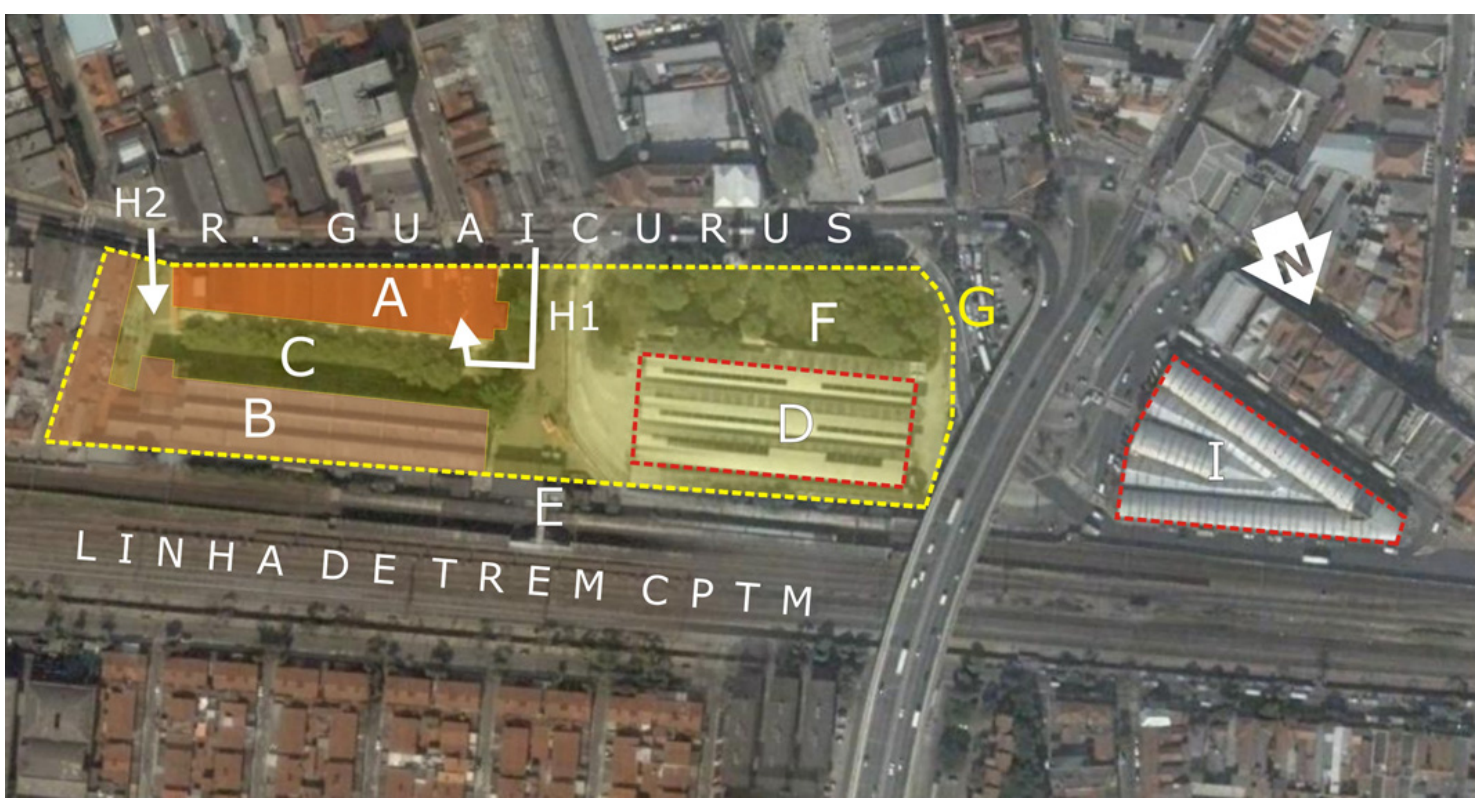

Figura 66 - I magem modificada pelo autor. Google, 2007.

\section{LEGENDA}

A - Estação Ciência

B - "Estação Especial” da Lapa

C - Antigo leito de ramal ferroviário.

D - Terminal de Ônibus da Lapa

E - Estação CPTM da Lapa

F - Praça Miguel dell'Erba
G - Área total inicialmente prevista para o projeto

H1 - Acesso à Estação Ciência

H2 - Acesso à Estação Especial da Lapa

I - Mercado da Lapa

Desde antes da construção do primeiro galpão nos anos 1930 havia duas linhas de trem, paralelas nesse trecho da Lapa, operadas pela Estrada de Ferro Sorocabana e pela São Paulo Railway. Em 1958 foi inaugurada a Estação Lapa da Sorocabana, que consolidou uma parada pré-existente ("Parada Lapa"), e que provavelmente atendia aos galpões industriais. Entre 1958 e 1971, a estação foi operada pela Sorocabana. Entre 1971 e 1994, pela FEPASA, e a partir de então pela Companhia Paulista de Transportes Metropolitanos (CPTM) ${ }^{222}$.

O edifício original e o novo projeto

Conforme comentado no parágrafo anterior, o galpão industrial original foi construído nos anos 1930, tendo de ser reconstruído pouco tempo depois em virtude do incêndio de 1936. O sistema estrutural original do edifício era composto

\footnotetext{
${ }^{222}$ ESTAÇÕES, 2007.
} 
por pilares e vigas de concreto, vedação em alvenaria de tijolos e cobertura em telhas cerâmicas apoiadas sobre estrutura de madeira. Havia vigas de concreto na periferia do edifício e transversais definindo cada um dos módulos da edificação, aproximadamente a cada $12 \mathrm{~m}$. Entre essas vigas havia tesouras de madeira obviamente com comprimento de $12 \mathrm{~m}$ - que sustentavam o telhado em sheds aproximadamente a cada $3,6 \mathrm{~m}^{223}$.

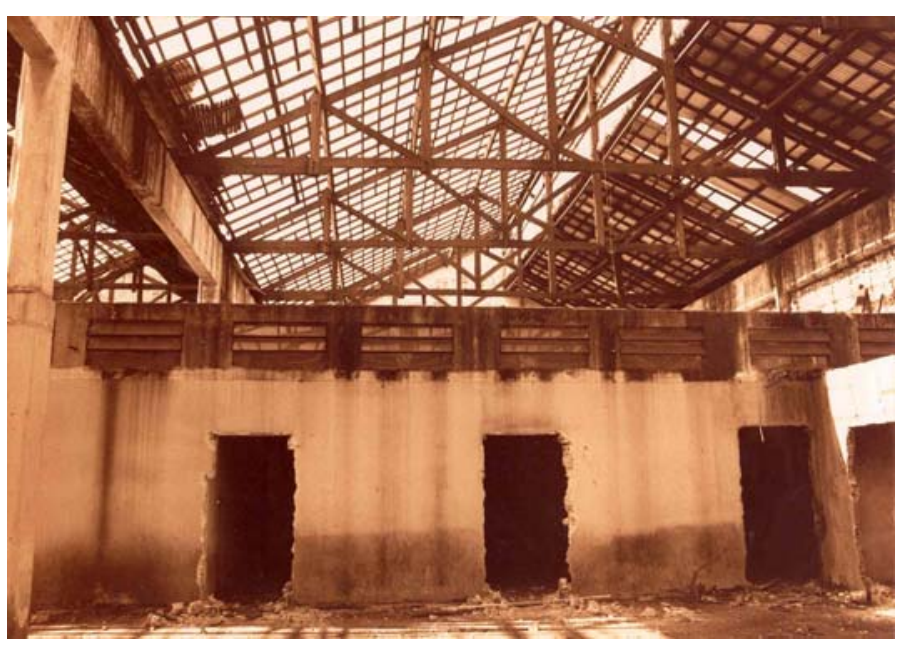

Fig. 67. Edifício antes das obras de restauro. Observa-se a estrutura de concreto e as tesouras de madeira. Acervo da Estação Ciência

Foi discutido anteriormente no capítulo (tópico 6.6.1), que, com o desenvolvimento do café a técnica construtiva da terra foi sendo substituída pela alvenaria portante de tijolos, e que o concreto armado viria a acompanhar a arquitetura industrial. $\mathrm{O}$ galpão original representa esse momento de transição do predomínio do café para o fortalecimento da indústria: utilizou estruturalmente o concreto - revestido, sem alteração na linguagem tradicional do galpão - e a estética do tijolo.

O escritório responsável pela concepção do projeto de restauro e reconversão em 1986 foi o de Marlene Yurgel, Lucio Gomes Machado e Eduardo de Jesus Rodrigues. Ele atendeu à "boa prática" no trato com o patrimônio arquitetônico. "As construções novas foram propostas e executadas com características formais e tecnologia contemporânea, de modo a enfatizar o momento em que essas

\footnotetext{
${ }^{223}$ RODRIGUES; MACHADO, 1998, p. 170.
} 
intervenções foram realizadas" ${ }^{224}$; inclusive com "cores e materiais de revestimentos para pisos e paredes diferentes dos originais" ${ }^{225}$. Os reforços na estrutura de madeira do telhado, realizados por motivos de segurança, utilizaram coloração diferente do madeiramento aposto. Foram inseridas novas tesouras entre as existentes.

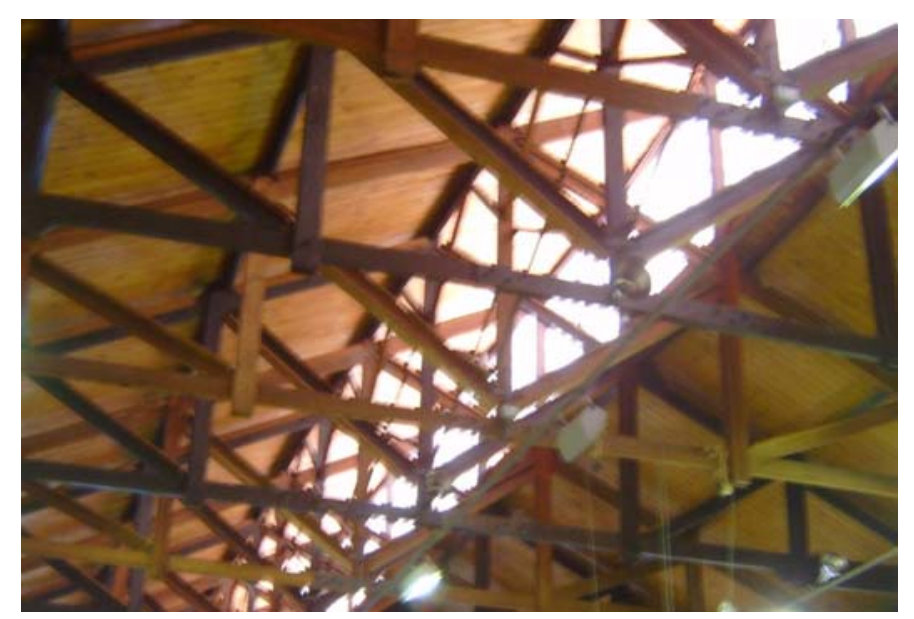

Fig. 68. As tesouras mais claras são adições visando o reforço estrutural. Foto do autor, 2007.

A estrutura original principal do edifício, em concreto, não teve que ser alterada. 0 forro de madeira, não-original, foi desenhado para impor mínima interferência no aspecto formal da estrutura, e foi uma das propostas do projeto de conforto térmico ${ }^{226}$, assim como o "isolante térmico especial entre as telhas e o forro" ${ }^{227}$, e o "sistema de ventilação forçada com tubulação aparente" 228.

Os vãos de janelas e portas foram mantidos. Quando não, foram "entaipados", mantendo-se a "a presença formal da abertura" ${ }^{229}$ e a modenatura original das fachadas.

Segundo Machado ${ }^{230}$, a idéia original era de uma ocupação espacial mais ambiciosa, composta por toda a área delimitada pelo tracejado amarelo (G),

\footnotetext{
${ }^{224}$ RODRIGUES; MACHADO, 1998, p. 173.

${ }^{225}$ Ibidem, p. 173.

${ }^{226}$ De autoria de Luis Carlos Chicherchio.

${ }^{227}$ HISTÓRIA, 1987, p. 226.

${ }^{228}$ Idem, p. 9.

${ }^{229}$ RODRIGUES; MACHADO, 1998, p. 172.

${ }^{230}$ Entrevista concedida ao autor em 16 nov. 2007.
} 
incluindo a área atualmente ocupada pelo terminal de ônibus (D) e pela Praça Miguel dell'Erba (F), sem descuidar do acesso à estação de trem (E).

Isso teria sido viável em 1986, pois o terminal de ônibus ainda não existia. Na época, foram formalmente cedidos, além da torre, seis dos doze módulos da edificação para a criação da Estação Ciência ${ }^{231}$. O módulo seguinte, de número 07, foi utilizado desde o início pela Estação, ainda que não the pertencesse oficialmente, como área administrativa e de infra-estrutura. Os módulos 07, 08 e 09 já estavam destinados ao CNPq, mas os módulos 10, 11 e 12 pertenciam à Sociedade Brasileira para o Progresso da Ciência (SBPC).

Entretanto, como já se negociava a saída da SBPC e a ocupação total do galpão pela Estação Ciência, o projeto e a execução da obra, pelo menos em sua parte estrutural, contemplavam desde o início todos os doze módulos. Entendeu-se que a execução em etapas tornaria a obra mais cara e complicada. Enquanto a cessão definitiva não acontecia, foi cuidadosamente construída uma divisória entre os módulos 09 e 10, que separava o galpão em dois blocos.

A mais significativa alteração feita ao longo dos anos na edificação antes de sua reconversão para a Estação Ciência foi a construção do mezanino que ocupa os módulos 04, 05 e 06. Apesar de sua estrutura em concreto ter sido superdimensionada, formando uma malha de pilares de aproximadamente $3,50 \mathrm{~m} x$ 4,00m ("paliteiro") o mezanino foi mantido, pois era área necessária, e, se demolido, teria que ser reconstruído de forma apropriada, onerando os cofres públicos ${ }^{232}$.

\footnotetext{
${ }^{231}$ Ver fig. 69, na próxima página.

${ }^{232}$ RODRIGUES; MACHADO, 1998. 


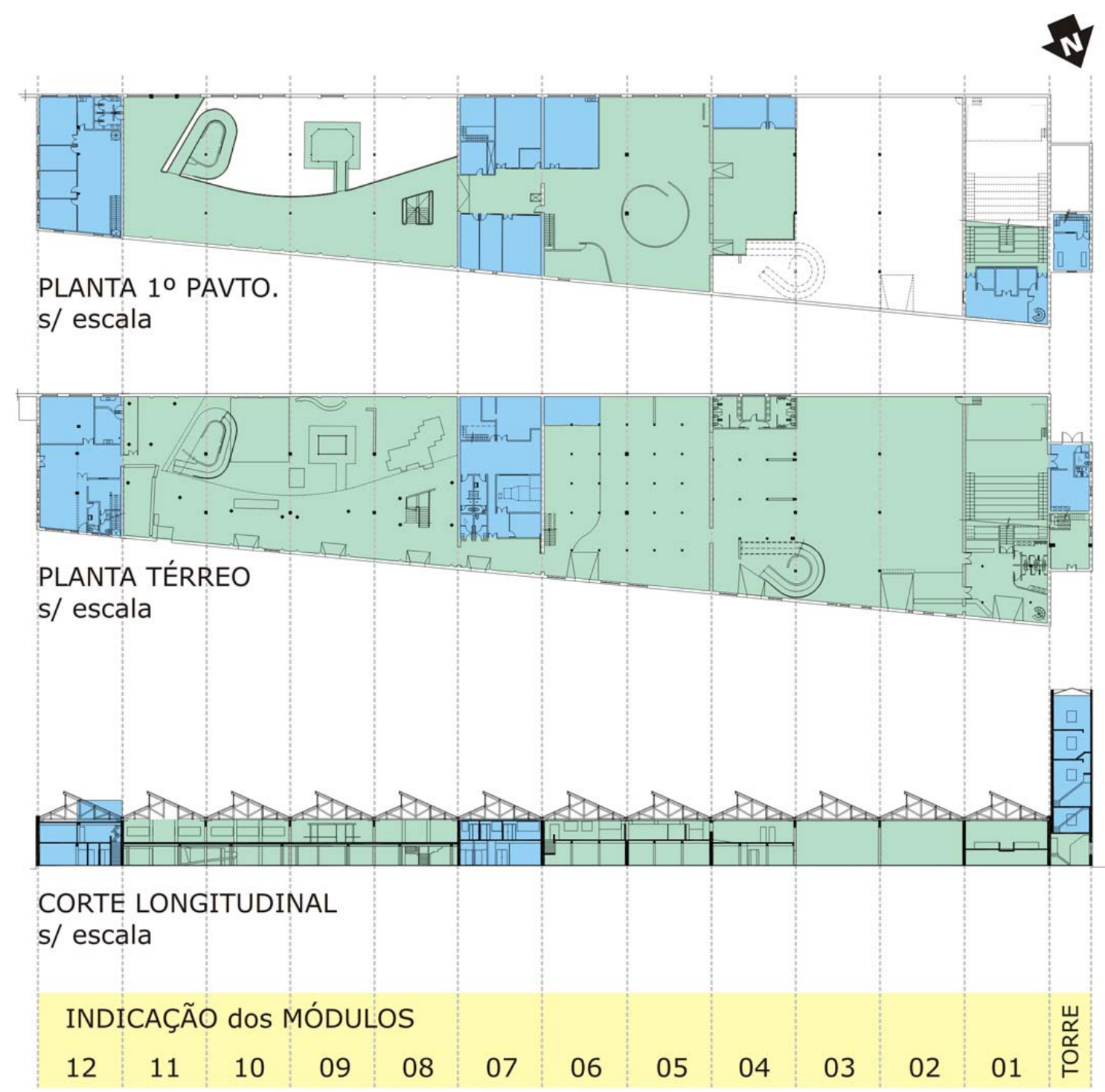

Figura 69. Áreas de exposições e/ou de acesso público em verde; áreas operacionais,

administrativas e/ou de acesso restrito em azul. Departamento de Arquitetura e Museografia da Estação Ciência da USP - levantamento "as-built". Imagem modificada pelo autor.

Após a conclusão da reconversão o edifício assumiu a seguinte configuração:

Torre - no térreo é dividida entre lanchonete pública e camarim para o auditório. Nos demais pavimentos é utilizada como depósito;

Módulo 01 - auditório e sua infra-estrutura, incluindo área administrativa no pavimento superior;

Módulos 02 e 03 - com pé direito duplo, abrigam exposições permanentes e exposições temporárias;

Módulo 04 - circulação vertical através de rampa, com área de exposições e sanitários no térreo, salas de apoio e exposições no pavimento superior; 
Módulo 05 - áreas de exposição em ambos os pavimentos;

Módulo 06 - salas de apoio, salas administrativas e salas de aula e outras atividades, em ambos os pavimentos;

Módulo 07 - salas de apoio operacional e administrativo em ambos os pavimentos;

Módulo 08, 09, 10 e 11 - novo mezanino parcial que se conforma ao longo dos quatro módulos, mantendo permeabilidade visual entre os pavimentos. Ocupado por áreas de exposição;

Módulo 12 - oficinas e áreas de vivência de funcionários no térreo, administração no primeiro pavimento, e arquitetura e museografia no mezanino.

O módulo 07 acabou se constituindo numa barreira à integração dos espaços do prédio. Apesar de não fazer parte oficialmente da área de cessão, teve de ser utilizada desde a inauguração por serviços essenciais como a cabine primária e a sala do exaustor, que ali se mantém até hoje. Ao longo dos anos têm sido feitos esforços para liberar seus espaços de forma a promover maior integração entre as duas "alas" da edificação.

Na fig. 69, a hachura verde representa áreas de exposições e/ou de acesso público, enquanto a hachura azul representa áreas operacionais, administrativas e/ou de acesso restrito. Observando-se o módulo 07, pode-se verificar claramente o quanto a circulação é "estrangulada" entre os módulos 06 e 08.

A região tem uma excelente infra-estrutura de transportes, o que é sem dúvida um ponto positivo para a instituição. Apesar disso, uma questão que se levanta é a integração da Estação Ciência com o seu entorno. O acesso não se dá pela Rua Guaicurus, mas contornando-se o edifício, pela face norte da edificação, oposta à rua. A primeira visita traz alguma dificuldade para descobrir sua entrada, e é bastante provável que muitas pessoas que por ali transitem diariamente não saibam que se trata de instituição aberta ao público, com exposições interessantes 
que podem proporcionar lazer cultural de qualidade. O pedestre da Rua Guaicurus não tem qualquer contato visual com as exposições.

Isto talvez não acontecesse no passado, quando o pórtico original por onde se dá o acesso à Estação Especial da Lapa (H2 - figura 01) indicava “Estação Ciência", e o primeiro acesso pudesse ser feito por ali. Vejamos duas fotos, a primeira de 1987 e a segunda de 2007:
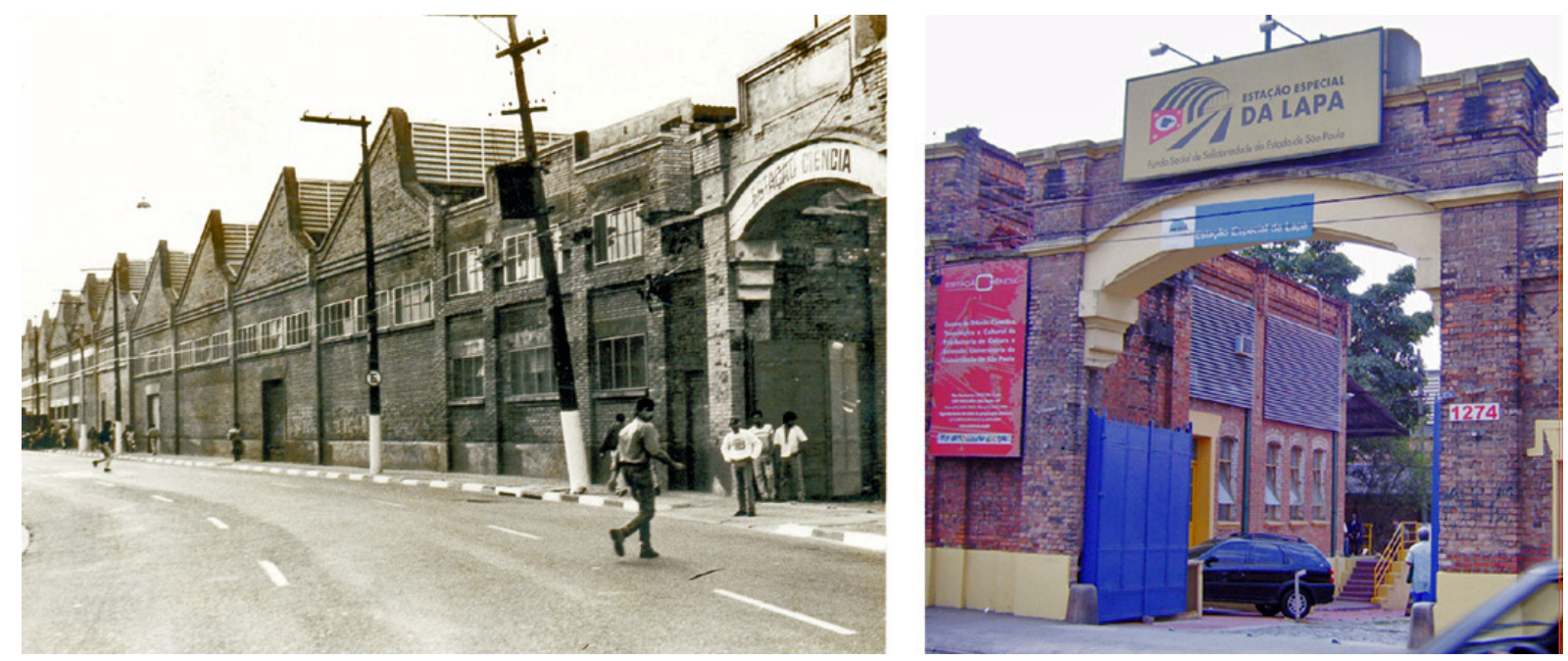

Figura 70. Esquerda - Foto de 1987 onde se pode observar o nome "Estação Ciência" no canto superior direito, indicando a possibilidade de acesso. Acervo da Estação Ciência.

Direita - No mesmo local, em 2007, observa-se apenas o indicativo do acesso da "Estação Especial da Lapa". Foto do autor.

Hoje, o acesso é induzido através do ponto $\mathrm{H}^{233}$.

Segundo Lucio Gomes Machado ${ }^{234}$, havia dois motivos principais para a escolha do acesso. Em primeiro lugar, considerou-se que aberturas para a Rua Guaicurus seriam prejudiciais para o conforto acústico da edificação. Em segundo, como a idéia original era de ocupação de área maior, constituindo o conjunto em um parque, a entrada principal do conjunto se daria pela Rua Guaicurus, mas as entradas dos edifícios com exposições internas estariam protegidas, mantendo-se na área (C) ${ }^{235}$, entre as edificações.

\footnotetext{
${ }^{233}$ Ver figura 66.

${ }^{234}$ Entrevista concedida ao autor em 16 nov. 2007.

${ }^{235}$ Ver figura 66.
} 
Consolidada a implantação atual, com ocupação apenas de um edifício, parece-nos que o conjunto se ressente de uma maior integração com a Rua Guaicurus.

Duas novas intervenções foram realizadas na Estação Ciência recentemente. Ambas utilizando como tema a plataforma, e compondo um trem para repousar sobre o ramal ferroviário interno que ali operou no passado, atendendo às instalações do galpão. Certamente, elas reforçam a idéia inexata de que ali um dia funcionou uma estação de trem - e não um mero ramal.

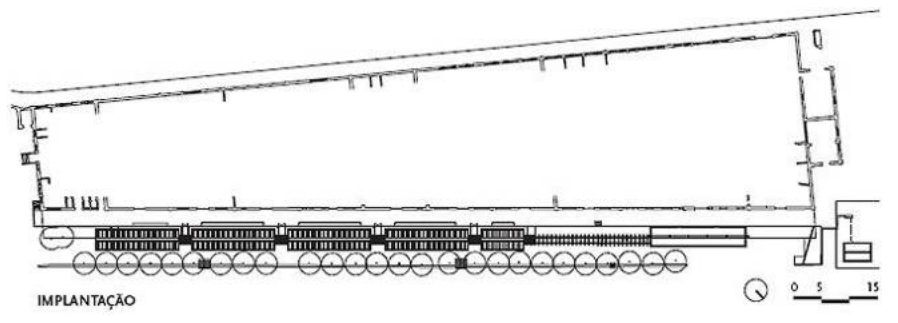

Fig. 71. Implantação da Cafeteria (à direita) e da Estação Natureza (cinco "vagões" à esquerda). Revista AU, 184, 2009.

A Cafeteria fica logo na entrada da Estação Ciência. Compõe-se de um "vagão" com $17 \mathrm{~m}$ de comprimento por $2,40 \mathrm{~m}$ de largura e pé-direito de $2,40 \mathrm{~m}$, em estrutura metálica e fechamentos vidro. O projeto, iniciado em 2004 por UNA Arquitetos, teve sua execução finalizada em 2009, após aprovação pelos órgãos ligados ao Patrimônio ${ }^{236}$.

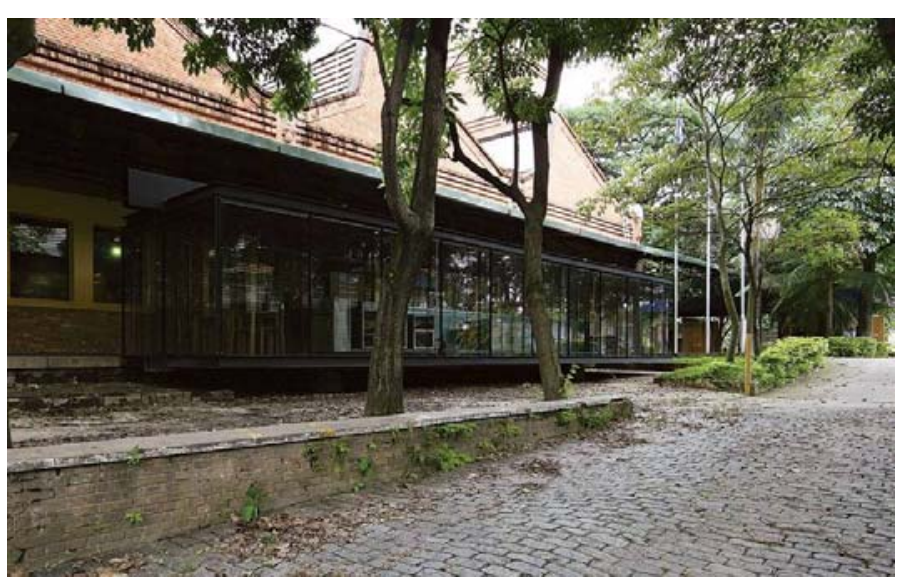

Fig. 72. Cafeteria. Revista AU, 184, 2009.

A outra intervenção é a Estação Natureza, com projeto arquitetônico e cenográfico de Brasil Arquitetura e Apiacás Arquitetos, concebido em 2006, para abrigar

${ }^{236}$ SILVA, 2009. 
exposições de seis biomas brasileiros. A idéia inicial era utilizar vagões reais ou réplicas, mas a equipe de arquitetos propôs sua substituição por "módulos que fizessem uma alusão ao trem", mais apropriados para a exposição, por não terem janelas. Essencialmente, o projeto é composto por cinco contêineres, sendo quatro deles de $15 \mathrm{~m}$ de comprimento, e o primeiro, mais próximo da cafeteria, com a metade desse comprimento, totalizando $266 \mathrm{~m}^{2}$ de área construída. Todos eles ficam alinhados sobre os trilhos. Como a Cafeteria, a Estação Natureza foi inaugurada em 2009.

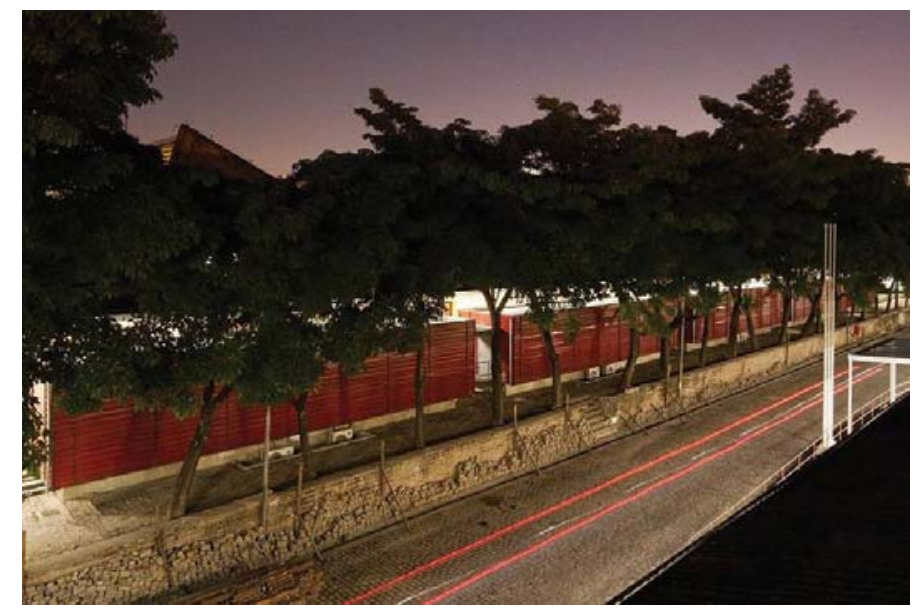

Fig. 73. Estação Natureza. Revista AU, 184, 2009.

Patrimônio arquitetônico

É importante observar que na época da criação da Estação Ciência, em 1986, não era comum no Brasil a preservação de exemplares de arquitetura industrial. O movimento em prol do tombamento, o início do estudo pelo Condephaat - que na prática garante sua preservação - e a efetiva reconversão do edifício são marcos importantes na história da preservação arquitetônica no Brasil. Corroborando esse fato, passaram-se mais doze anos até a fundação, em 1998, do Comitê Brasileiro de Preservação do Patrimônio Industrial, que é o representante brasileiro do The International Committee for the Conservation of Industrial Heritage $(\mathrm{TICClH})^{237}$.

${ }^{237}$ MEHRTENS, 2007. 
Os galpões, em 1986, estavam bastante degradados, em situação de abandono, conforme se pode observar nas fotos da época:
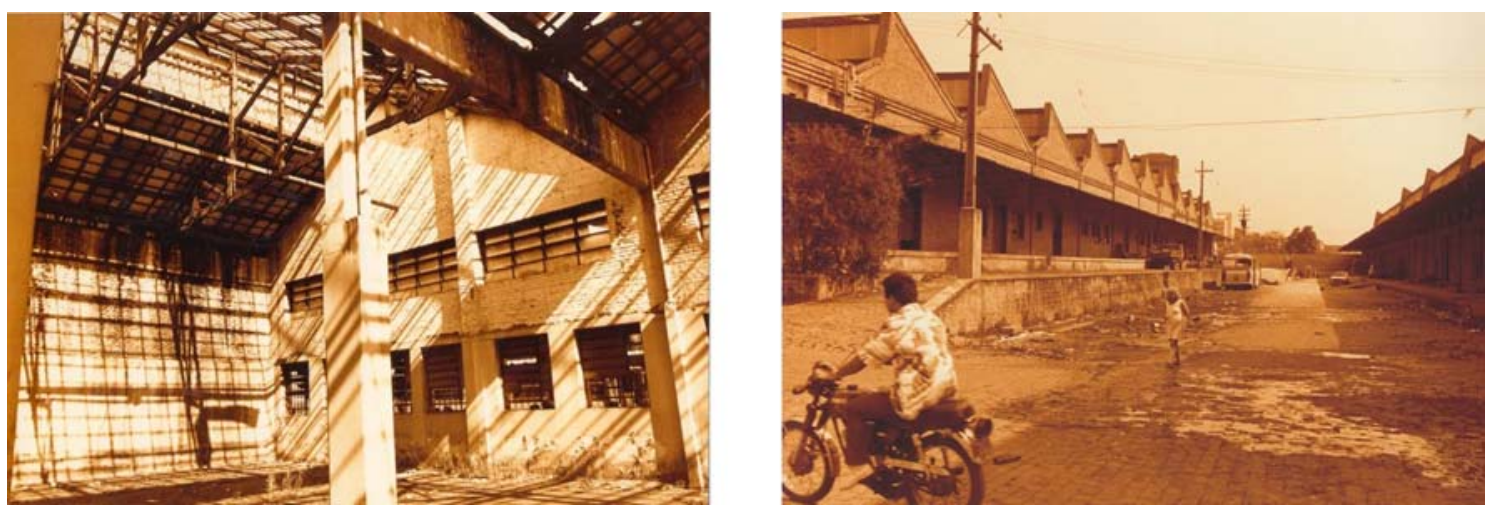

Fig. 74. Fotos imediatamente anteriores à reconversão. À esquerda, interna, 1986. À direita, externa (área "C" da fig. 66), 1987. Acervo da Estação Ciência.

O projeto da Estação Ciência, além de dar uma destinação positiva para o edifício, apresenta solução espacial dinâmica, conseqüência do jogo de circulação vertical com rampas e escadas e da forma da laje do novo mezanino.

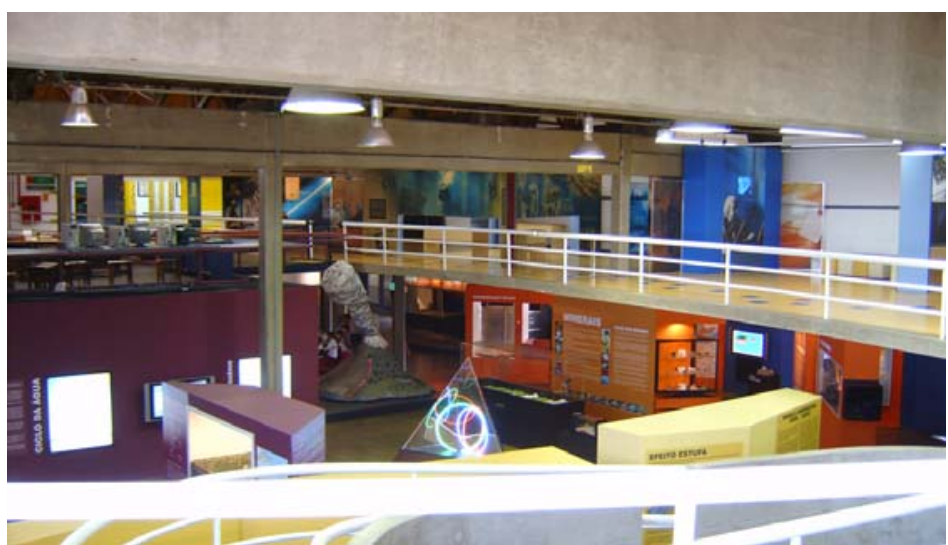

Fig. 75. Vista geral dos módulos 11, 10, 09 e 08 (ver fig. 69). 2007. Foto do autor. 


\subsubsection{Espaço Ciência, Recife, Pernambuco}

Introdução, Origens e Contexto Histórico, Localização.

O Espaço Ciência foi criado em 1994 pela Secretaria de Ciência e Tecnologia do Estado de Pernambuco, quando então funcionava num casarão alugado no Bairro das Graças. Em 1996 passou a ocupar o seu terreno atual ${ }^{238}$.

Ocupa uma área de 120 mil metros quadrados no Parque Memorial Arcoverde, circundada "por autopistas, viadutos, áreas verdes, manguezais, equipamentos culturais, recreativos e comerciais, na ligação entre Recife e Olinda" ${ }^{239}$. Segundo Pavão e Leitão, "é o maior museu a céu aberto do Brasil e um dos maiores do mundo" ${ }^{240}$, com a maioria de seus cerca de duzentos experimentos interativos ocupando áreas externas.

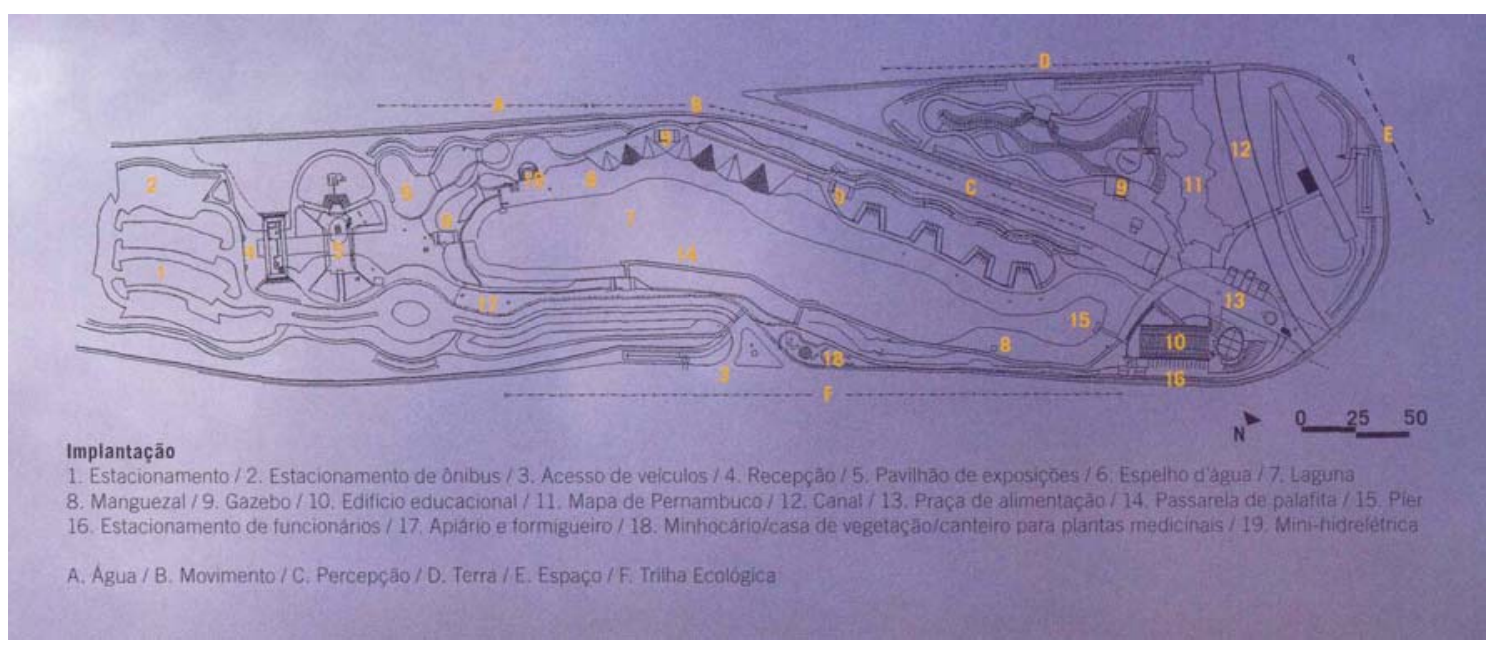

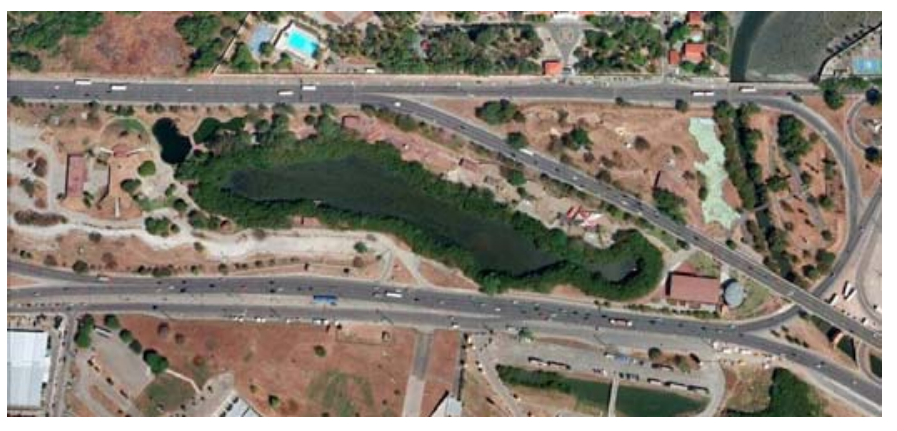

${ }^{238}$ ESPAÇO, 2011.

${ }^{239}$ MELENDEZ, 2007, p. 42.

${ }^{240}$ PAVÃO; LEITÃO, 2007, p. 42.
Fig. 76. Acima. Implantação. Revista Projeto Design, 328, 2007.

Fig. 77. Esquerda. Foto aérea. Notar o viaduto transversal que corta o Espaço Ciência à direita. Google, 2009. 
Como a Estação Ciência, em São Paulo, o Espaço Ciência também desenvolve atividades relacionadas à inclusão social, especialmente de jovens moradores do entorno, através de "projetos de inclusão digital, de linguagem teatral, de produção de jogos educativos, dentre outros" 241.

Os edifícios e o paisagismo

A implantação, iniciada em 2002 e concluída em 2004, teve de ser autorizada pelo Iphan, pelo Ibama e pela Comissão do Sítio Histórico de Olinda ${ }^{242}$. O projeto paisagístico, de autoria de Luis Vieira, tem grande relevância, não só por isso mas também porque a maior parte do programa do Espaço Ciência "se estabelece a céu aberto", como é o caso da Trilha da Descoberta - cujas atrações estão subdividas em "cinco setores temáticos: água, movimento, percepção, terra e espaço" - e da Trilha Ecológica ${ }^{243}$.

O conjunto arquitetônico atual é composto essencialmente pela recepção e pavilhão de exposições, e pelo edifício educacional.

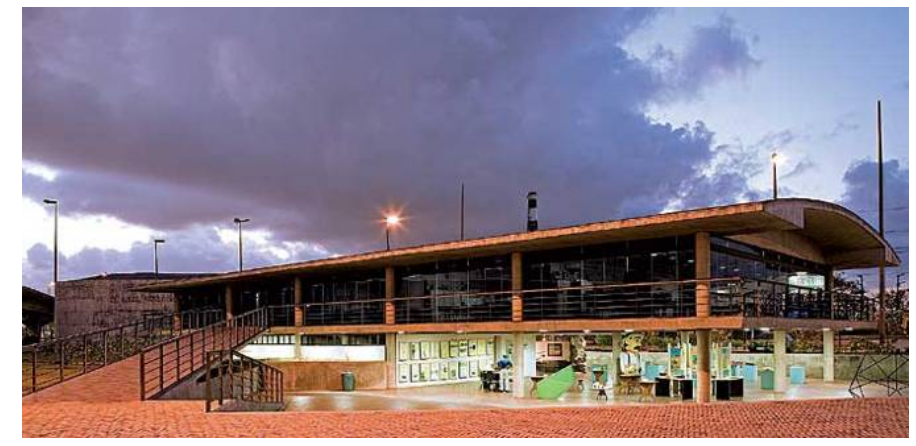

Fig. 78. Edifício educacional, com auditório ao fundo, lado esquerdo. Revista Projeto Design, 328, 2007.

O edifício do pavilhão de exposições (ver fig. 79) foi projetado em 1986 por Acácio Gil Borsoi e Marco Antonio Gil Borsoi, seu filho, para múltiplos usos. Segundo Melendez, é uma “edificação quase neutra, que tem como expressão plástica mais

\footnotetext{
${ }^{241}$ PAVÃO; LEITÃO, 2007, p. 42.

${ }^{242}$ MELENDEZ, 2007, p. 42.

${ }^{243}$ Ibidem, p. 43.
} 
visível uma colina, formada por taludes gramados que buscam dar continuidade ao verde do parque" ${ }^{244}$. No projeto atual, entretanto, de autoria de Borsoi filho e Tereza Cristina Simis, os interiores do edifício foram readequados para funcionarem como espaço de exposição permanente ${ }^{245}$.

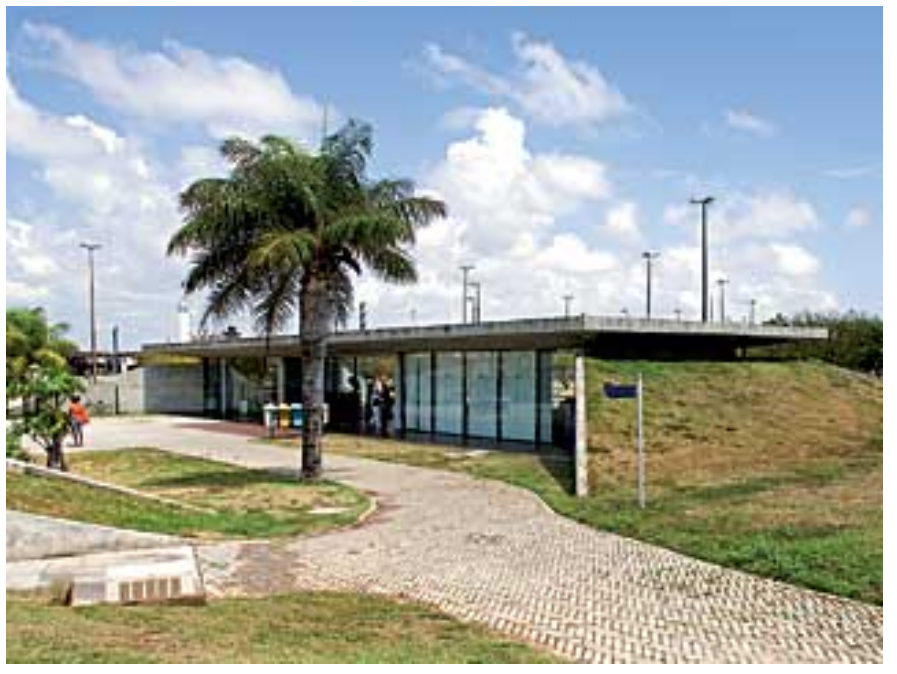

Fig. 79. Pavilhão de Exposições. Revista Projeto Design, 328, 2007.

A nova edificação é composta por um corpo elíptico que abriga o auditório e uma sala de exposição, conectada a um corpo retangular que abriga áreas de exposição, salas de aula, administração e serviços. Este "é uma composição de planta livre e estrutura aparente com pilares cilíndricos e cobertura arqueada com grandes beirais" ${ }^{246}$, na qual os autores tiveram a preocupação de não "ultrapassar o ponto mais alto da obra viária" 247.

Sua arquitetura "estabelece ligações com a obra de Acácio Gil Borsoi" e com a própria arquitetura moderna brasileira, da qual Borsoi foi um dos representantes mais significativos em Pernambuco. Borsoi filho cita explicitamente a adoção dos princípios corbusianos de "pilotis, planta livre, teto-jardim, fachada livre e aberturas contínuas" 248

\footnotetext{
${ }^{244}$ MELENDEZ, 2007, p. 44.

${ }^{245}$ Ibidem, p. 48.

${ }^{246}$ Ibidem, p. 44.

247 Ibidem, p. 43.

248 Ibidem, p. 48.
} 
6.2.4 Museu de Ciências e Tecnologia (PUCRS), Porto Alegre, RS

Introdução. Origens e contexto histórico.

Em julho de 1967 foi criado oficialmente o Museu de Ciências, como novo departamento da Pontifícia Universidade Católica do Rio Grande do Sul (PUC-RS), universidade. Foi uma iniciativa do Prof. J eter Bortoletti, que foi também seu diretor a partir daquele momento ${ }^{249}$, até 2007. O museu compôs seu quadro de funcionários inicialmente com 51 pessoas, sendo 14 docentes, dois técnicos e o restante de bolsistas, monitores e estagiários ${ }^{250}$.

Em 1973 foi elaborado projeto de prédio próprio para o Museu, pelo arquiteto Alfredo Porto Alegre, com área total de $3.630 \mathrm{~m}^{2}$, orçamento de US\$886.000,00 e desenhos técnicos de Henrique Rocha - que viria a projetar a nova sede anos depois $^{251}$. O projeto foi aprovado pelo então Reitor Ir. José Otão, mas não se concretizou "devido a outras prioridades" 252. Assim, em 1985 o Museu, com uma coleção composta por mais de cinco mil peças, ainda estava espalhado em diversos prédios da $\mathrm{PUC}^{253}$.

Em 1988 Bortoletti elaborou anteprojeto (não-arquitetônico) contendo "os assuntos e roteiros da nova exposição" ${ }^{254}$. No mesmo ano foi definida a construção de um edifício para sede do Museu, voltado diretamente para a Avenida I piranga, principal acesso do Campus da PUC, prevendo área total próxima de $11.000 \mathrm{~m}^{2}{ }^{255}$. Em 1993 "foram inaugurados o Centro de Ciências e Cultura e o novo prédio do Museu, agora denominado Museu de Ciências e Tecnologia da PUCRS (MCT)" 256, e em 1998 foi inaugurada a nova área de exposições, “com cerca de 600 experimentos

\footnotetext{
${ }^{249}$ DIVULGAÇÕES, 2006, p. 24.

250 Ibidem, p. 25.

${ }^{251}$ Ibidem, p. 26.

252 Ibidem, p. 27.

253 Ibidem, p. 27.

254 Ibidem, p. 28.

255 Ibidem, p. 28.

${ }^{256}$ Ibidem, p. 29.
} 
interativos, ocupando uma área de $12.500 \mathrm{~m}^{2} "{ }^{257}$, com significativo apoio financeiro da Fundação Vitae, de mais de seiscentos mil reais e dois milhões de dólares. A Vitae continuou apoiando o MCT nos anos seguintes, compondo, no total, a cifra de $\mathrm{R} \$ 1.974 .554,00$ e US\$2.247.328,00.

Em 2007 houve uma troca na direção do MCT, inserida em um contexto de mudanças na estrutura administrativa: o museu passou a ser gerido através de um colegiado composto de seis pessoas: o diretor (Prof. Emilio A. Jeckel Neto), o vicediretor (Prof. Roberto Reis) e os quatro coordenadores (administrativo, educacional, de exposições, e de coleções científicas) ${ }^{258}$.

Um diferencial do MCT em relação aos centros de ciências típicos é que ele apresenta grandes e importantes coleções científicas. A maioria dos espécimes não é exposta ao grande público, servindo especificamente à pesquisa. Entretanto, eventualmente são selecionados exemplares para compor exposições.

Localização

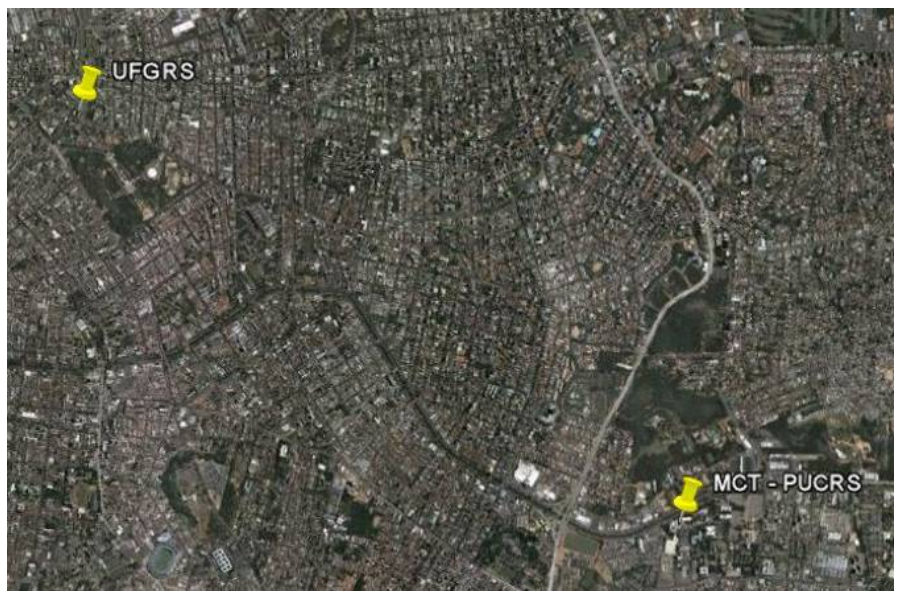

Fig. 80 - Foto aérea mostrando a situação do MCT em relação à Universidade Federal do Rio Grande do Sul, no centro de Porto Alegre. Google, 2011.

\footnotetext{
${ }^{257}$ DIVULGAÇÕES, 2006, p. 29.

${ }^{258}$ Informações de Roberto Reis. Entrevista concedida ao autor em 22/07/2009.
} 
A PUC fica a cerca de $7 \mathrm{~km}$ do centro de Porto Alegre, com excelente acessibilidade através de linhas de ônibus. Como o MCT é lindeiro à Av. Ipiranga, sua entrada é independente daquela da universidade.

O edifício

O projeto realizado da sede própria do MCT - incluindo a programação visual - é de autoria dos arquitetos Henrique Rocha e Cícero Santini, do escritório Santini \& Rocha, e foi iniciado em 1988. Rocha é funcionário da PUC desde 1985, atualmente dividindo seu tempo como assessor de arquitetura e docente da universidade e titular do próprio escritório.

Quando foi definido que a PUC construiria uma sede própria para o MCT, Rocha foi encarregado de fazer uma visita técnica de um mês a diversos museus de ciência e tecnologia do mundo para se preparar para o desenvolvimento do projeto. Os museus que mais o impressionaram e influenciaram foram o Deutsches Museum, em Munique, Alemanha, e o museu da Philips, Evoluum, em Eindhovem, Holanda (já demolido). Ambos com um grande átrio central - solução que foi utilizada no MCT com o intuito de integrar todas as áreas de exposições ${ }^{259}$.

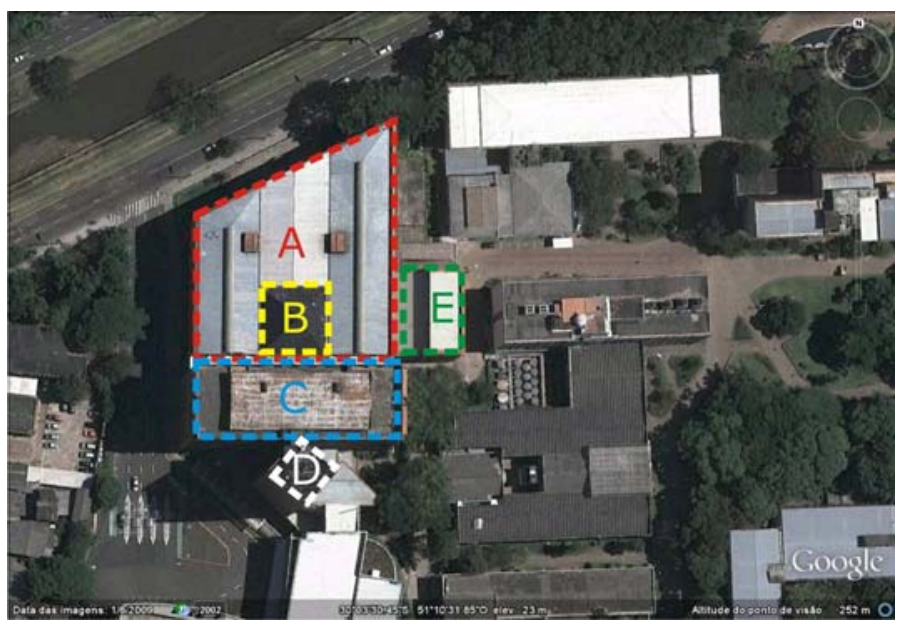

Fig. 81 - Foto aérea mostrando a implantação do MCT. I magem modificada pelo autor. Google, 2009.

LEGENDA:

A - Bloco principal.

B - Pirâmide de vidro.

C - Torre 01.

D - Torre 02.

E - Teatro.

\footnotetext{
${ }^{259}$ Informações de Henrique Rocha. Entrevista concedida ao autor em 21/07/2009.
} 
Identifica-se um conjunto edificado composto por quatro volumes. O bloco principal, ao norte, é um paralelogramo (A), em planta, que se eleva e compõem as áreas de visitação do museu. Parte desse bloco é coberto por uma pirâmide de vidro, ao centro (B). Dois outros blocos não têm relação funcional nenhuma com ele: são a torre de planta retangular, ao sul (C), e, ainda mais ao sul, uma torre um pouco mais alta e de planta quadrada, com cobertura inclinada (D). Completa o volume o bloco do teatro (E), ao leste, também de planta retangular e cobertura metade plana e metade inclinada ${ }^{260}$.

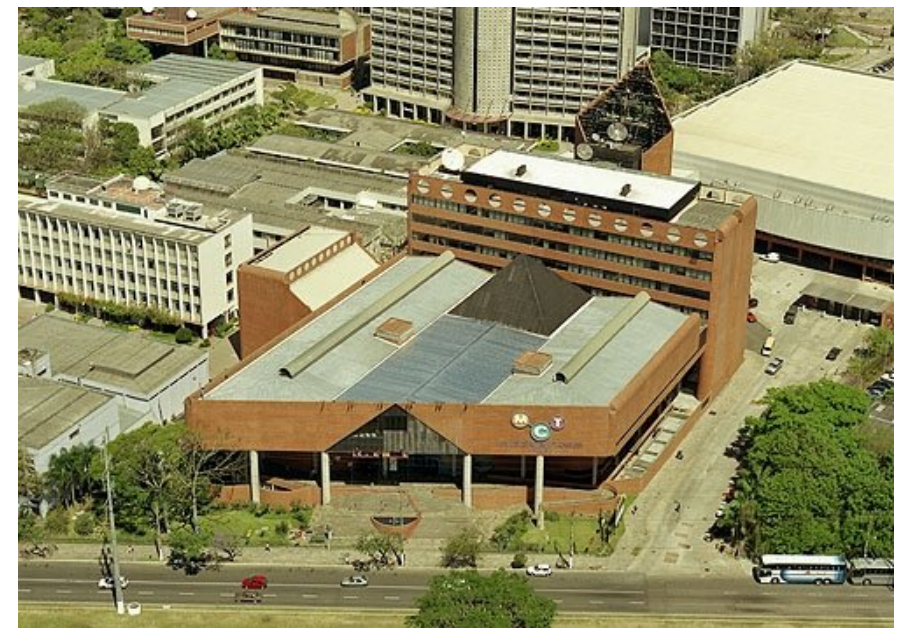

Fig. 82 - Vista geral do MCT. Santini e Rocha (homepage dos arquitetos).

O Subsolo é totalmente enterrado, enquanto o Térreo, ainda que semi-enterrado, não tem aberturas para o exterior. O Subsolo concentra as coleções (peixes, plantas, insetos, etc.), e laboratórios, enquanto o Térreo as áreas administrativas. Reis comentou que a administração e as áreas técnicas se ressentem de um maior cuidado com o projeto de seus espaços ${ }^{261}$. Não há ventilação ou iluminação natural. Rocha admite que "as áreas de laboratórios ficaram muito mal-resolvidas" 262.

O primeiro, o segundo e o terceiro pavimentos são de exposições. No primeiro pavimento se dá o acesso do visitante, se localiza a loja, a bilheteria e o saguão de entrada. Passando as catracas chega-se ao grande átrio que permeia todos os

\footnotetext{
${ }^{260}$ Ver fig. 81, na página anterior.

${ }^{261}$ Informações de Roberto Reis. Entrevista concedida ao autor em 22/07/2009.

262 Informações de Henrique Rocha. Entrevista concedida ao autor em 21/07/2009.
} 
pavimentos de exposição. O átrio concentra as exposições temporárias, enquanto na sua periferia, com pé direito simples, se encontram exposições permanentes.

De acordo com o projeto básico, a distância de laje a laje do primeiro ao segundo pavimento é de $3,70 \mathrm{~m}$, sendo $2,92 \mathrm{~m}$ livres e 0,78 de laje + vigas. Já no terceiro pavimento a cobertura é composta por um sistema em treliça metálica espacial de $1,20 \mathrm{~m}$ de espessura e 5,37m livres.

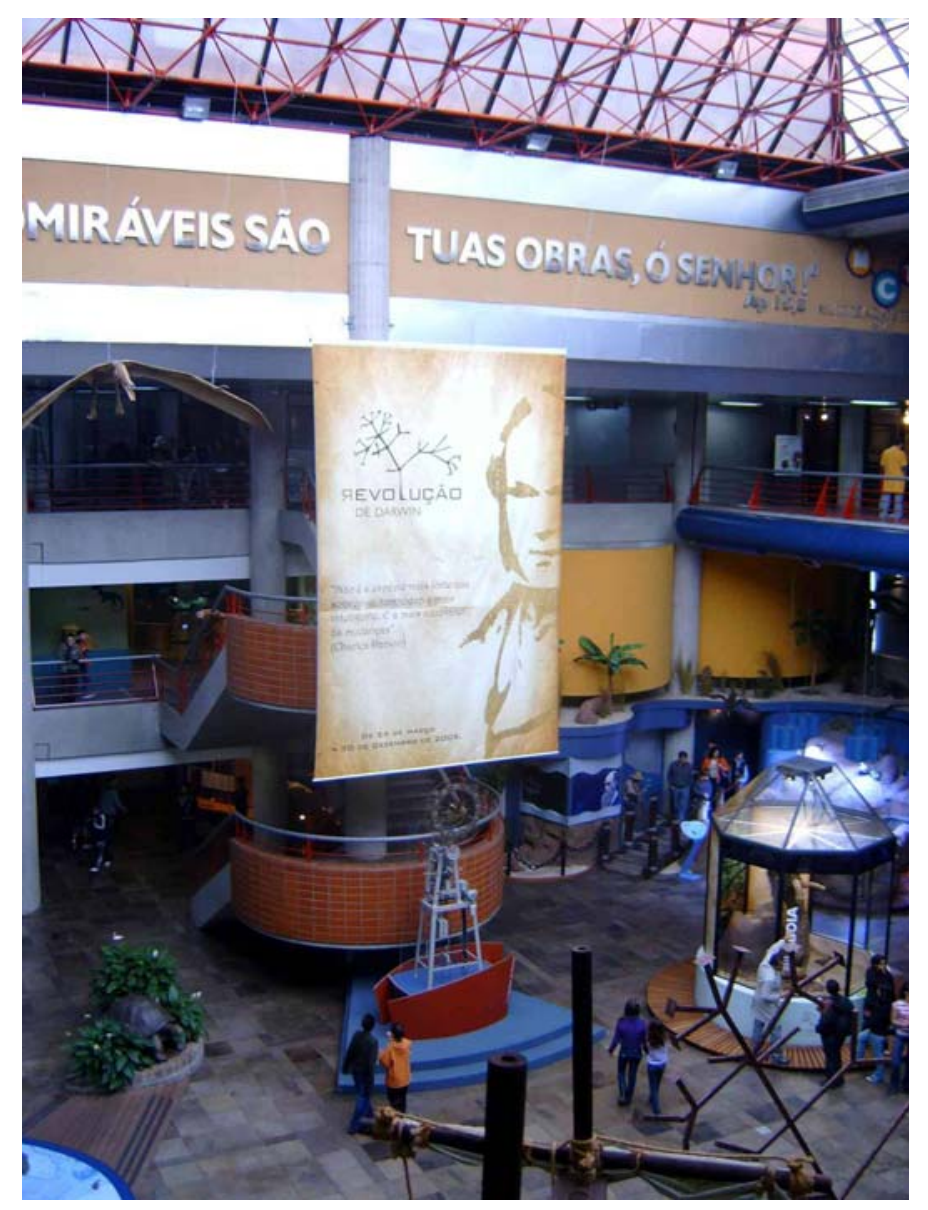

Fig. 83 - Átrio. Foto do autor, 2009.

O segundo pavimento tem projeção idêntica à do primeiro, mas área menor devido à supressão da área do átrio. A área de exposição, entretanto, é semelhante, pois no primeiro estão as áreas de acesso. As exposições são apresentadas de forma compartimentada, com luz controlada, o que permite uma maior inserção no tema.

O terceiro pavimento apresenta área maior, pois as fachadas norte e oeste, que nos pavimentos 1 e 2 se encontram recuadas, avançam até a projeção do edifício e 
existem duas áreas de mezaninos - possíveis em virtude do pé direito mais alto. Além disso, ele concentra as exposições de Física em arranjos nãocompartimentados, o que faz o visitante perceber o espaço como ainda maior - e mais barulhento. Ali se localizam duas salas de atividades especiais e um anfiteatro.

A circulação vertical entre os três pavimentos se dá por escadas rolantes e escadas convencionais. Todos apresentam sanitários públicos para ambos os sexos. Os mezaninos são acessados por escadas e rampas.

Incluído no projeto do museu está o Teatro, concebido por Rocha como um espaço a ser utilizado pelo Museu para grandes demonstrações, shows e peças com temas científicos $^{263}$. Nunca foi efetivamente utilizado dessa forma, mas essencialmente como o teatro da universidade, com entrada independente do Museu, pelo campus, onde consta o letreiro "Teatro da PUCRS". O acesso é discreto - na verdade malelaborado - tanto pela Universidade quanto pelo MCT.

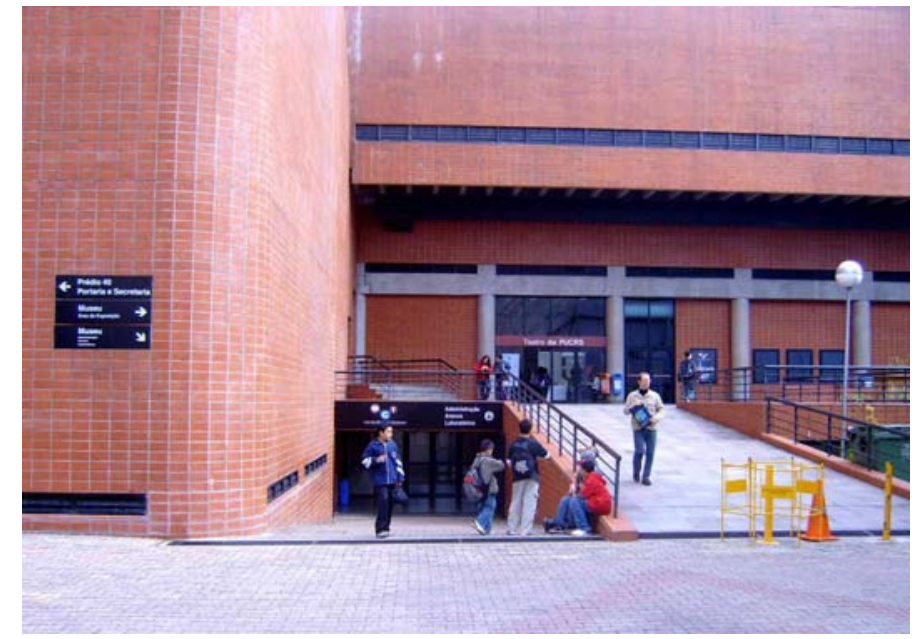

Fig. 84 - Entrada do Teatro (subindo a rampa). Foto do autor, 2009.

A estrutura geral do conjunto é composta por lajes, vigas e pilares em concreto armado. Os pilares apresentam seção circular de $70 \mathrm{~cm}$ de diâmetro compondo uma malha ortogonal de $5 \mathrm{~m} \times 10 \mathrm{~m}$. Essa malha é interrompida no átrio de $30 \mathrm{~m} \times$ $30 \mathrm{~m}$. A estrutura dos mezaninos do terceiro pavimento é de vigas metálicas I

${ }^{263}$ Informações de Henrique Rocha. Entrevista concedida ao autor em 21/07/2009. 
fixadas nos pilares de concreto. A cobertura, em telhas trapezoidais e vidro, é suportada por treliças metálicas espaciais.

O espaço interior do edifício é muito mais bem sucedido do que o exterior. Os interiores são bonitos, dinâmicos e funcionais, com espaços mais amplos e versáteis para exposições maiores; e espaços menores, mais intimistas, onde o conforto sonoro e a possibilidade de imersão são maiores. Ali se localizam diversos dioramas e exposições variadas.

Já a volumetria e a composição geral externa parecem não se harmonizar. A fachada principal, que se volta para a Av. Ipiranga, apresenta quatro colunas circulares de concreto aparente e um frontão triangular de vidro sobreposto ao pano retangular horizontal, revestido de cerâmica imitando tijolo (ver figura 79). As quinas do edifício não têm pilares. O conjunto não funciona como colunata, devido à pequena quantidade de pilares, nem tem expressão estrutural suficientemente para justificar o destaque dado aos pilares tanto pelo fundo ocre da cerâmica quanto pela sua própria esbelteza e aparente insuficiência numérica. A pirâmide de vidro, que cobre o átrio central, nos remete obviamente à do Louvre, concebida poucos anos antes. Quer apreciemos ou não a original - que estabelece um contraponto com o edifício pré-existente - a sua localização em relação ao conjunto e o impacto na composição do espaço interno são muito mais bem-sucedidos do que a do $\mathrm{MCT}$, que, adjacente em um dos lados à torre retangular, parece não conseguir encontrar seu próprio espaço. 
6.2.5 Outros centros de ciências relevantes: Sabina - Escola Parque do Conhecimento, Santo André, SP (Paulo Mendes da Rocha); Catavento Cultural, São Paulo, SP; Estação Cabo Branco, João Pessoa, PB.

Escola Parque do Conhecimento / Sabina, Santo André, SP

Sabina - Escola Parque do Conhecimento, Santo André, São Paulo, Brasil. O Sabina é uma instituição municipal de Santo André, cujo projeto arquitetônico foi concebido por Paulo Mendes da Rocha. É um museu de ciências aberto à visitação pública desde fevereiro de 2007, e que abriga também atividades científicas, artísticas e eventos diversos.

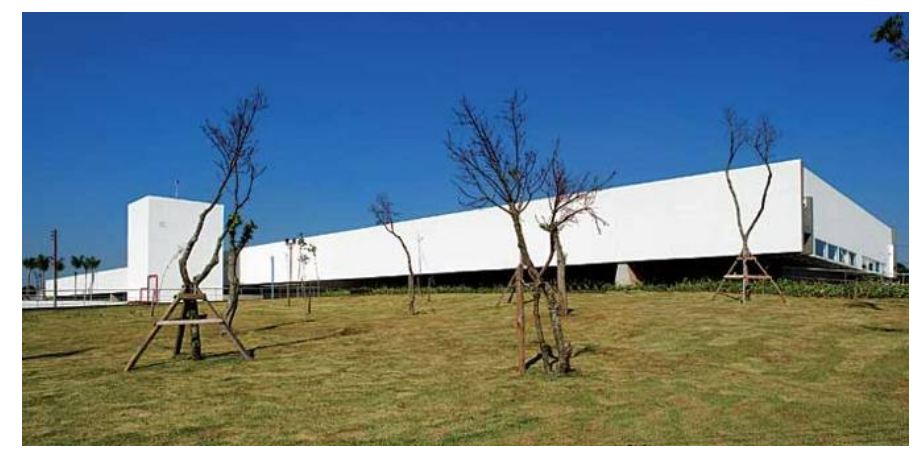

Fig. 85 - Vista geral do edifício. A torre, do lado esquerdo, tem altura muito inferior à necessária para o funcionamento de um Pêndulo de Foucault. Revista Projeto Design 330, 2007.

O edifício é um pavilhão semi-enterrado de $181 \mathrm{~m}$ de comprimento e $31 \mathrm{~m}$ de largura, com espaços amplos e dois átrios que dão permeabilidade visual às áreas internas: ali o pé direito atinge $15 \mathrm{~m}$. Há caixilhos horizontais que propiciam ventilação constante e iluminação natural indireta, mas sem abrir o edifício visualmente para o seu entorno, o Parque Central, do qual ocupa uma área de $35.000 \mathrm{~m}^{2}$. Havia a previsão de um bloco anexo para auditório, que não foi construído, e de uma torre para a instalação de um Pêndulo de Foucault, cuja redução da altura - acreditamos que na fase de execução - torna impossível instalar um pêndulo que funcione de fato. 


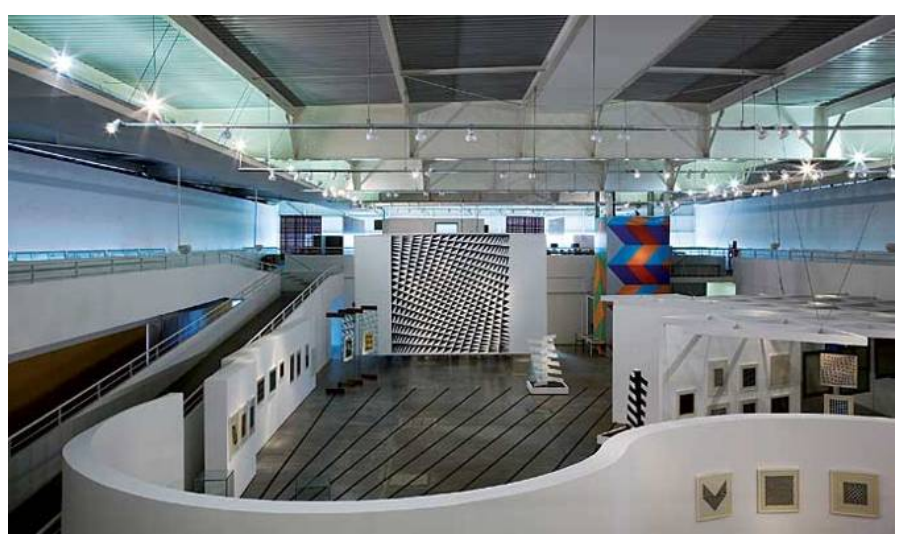

Fig. 86 - Átrio. Revista Projeto Design 330, 2007.

O acesso do pedestre ao edifício se dá através de uma rampa que leva ao pavimento inferior. "Segundo Mendes da Rocha, esse desenho do acesso toma por inspiração as cavernas pré-históricas, como a de Altamira, na Espanha" 264. Segundo Fernando Serapião, entretanto, tanto essa entrada quanto o efeito geral do edifício não fazem jus à capacidade projetual de Paulo Mendes da Rocha ${ }^{265}$.

É interessante como, também inserido numa área de parque, a California Academy of Science de Renzo Piano tem abordagem totalmente diferente, abrindo-se completamente para o exterior, até porque, segundo Piano, a beleza do parque tem que ser vista ${ }^{266}$. Ainda que o entorno da Academia seja bem mais atraente do que o do Sabina, parece-nos que o raciocínio continua válido - até porque a própria implantação da instituição em seu terreno pode trazer contribuição paisagística positiva.

Catavento Cultural e Educacional, São Paulo, SP

O Catavento Cultural e Educacional é um centro de ciências aberto pela Prefeitura de São Paulo em 2007, no Palácio das Indústrias, no Parque D. Pedro II, região central da cidade, com $4.000 \mathrm{~m}^{2}$ de área de exposição. Não houve divulgação da

\footnotetext{
${ }^{264}$ CORBIOLI, 2007.

265 Ibidem.

${ }^{266}$ Ver nesse mesmo capítulo o tópico 6.1.2.
} 
autoria do projeto arquitetônico de reconversão, e não obtivemos resposta da instituição ao procurá-la para obter maiores informações.

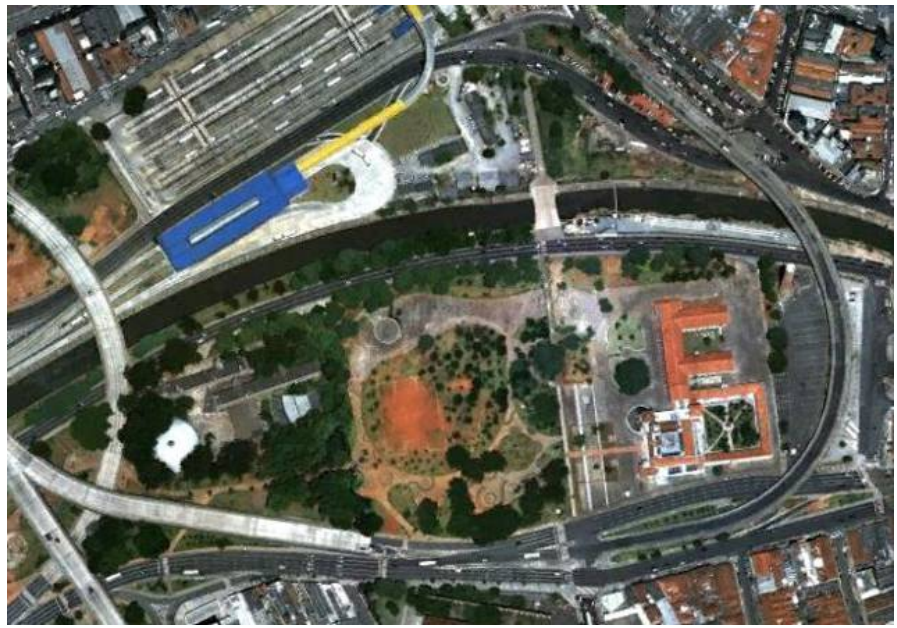

Fig. 87 - Foto aérea. Google, 2009.

Há uma massa crítica suficiente de exposições, algumas muito interessantes. A ambientação cenográfica é tecnicamente de boa qualidade. Há também, sem dúvida, exposições tendendo para a espetacularização - muita forma e pouco conteúdo.

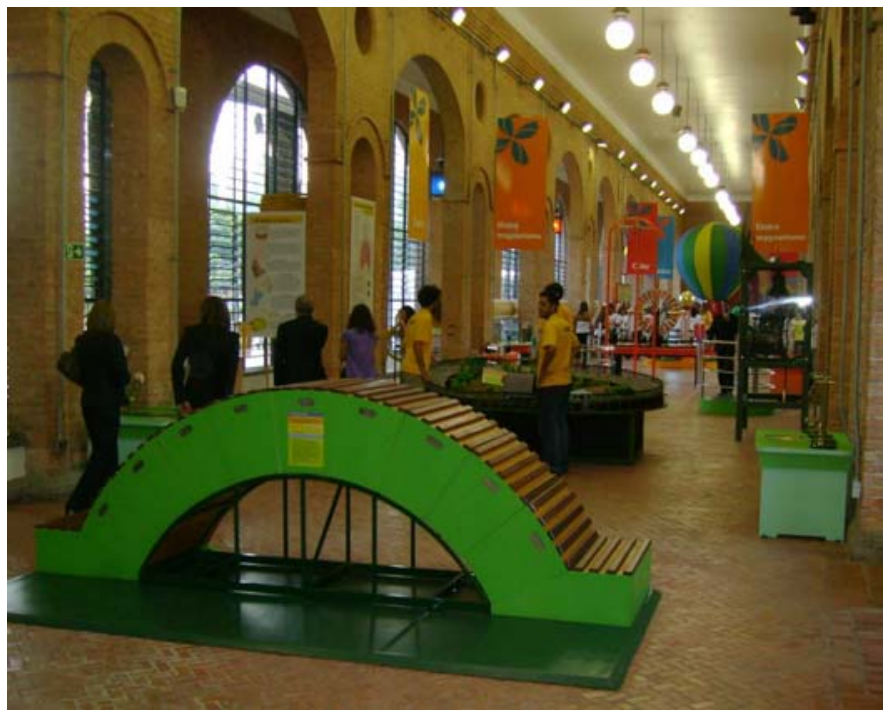

Fig. 88 - Exposição de física. Em primeiro plano, interessante modelo interativo com partes móveis que demonstra o funcionamento do arco romano. 2009. Foto do autor. 
Estação Cabo Branco, João Pessoa, Paraíba.

Inaugurado em julho de 2008, é um projeto de Oscar Niemeyer, com pouco mais de $8.500 \mathrm{~m}^{2}$ de área construída. Conta com uma exposição científica interativa na área externa - um percurso -, denominada "Museu de Ciência e Tecnologia", além de espaços para exposições científicas e artísticas, auditório para 500 pessoas, anfiteatro a céu aberto para 300 pessoas, salas para eventos e salas de aulas, distribuídos em cinco edifícios.

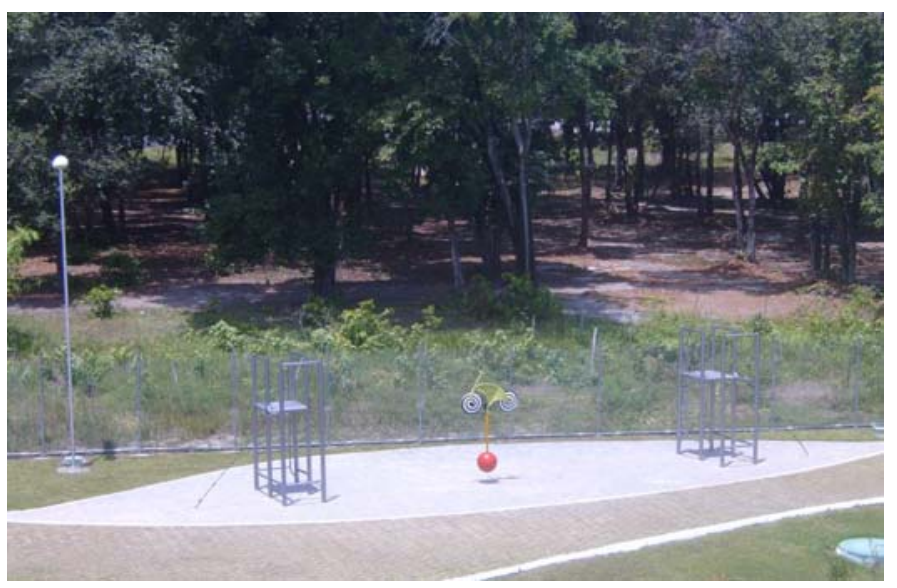

Fig. 89 - Bicicleta aérea. Exemplo de exibição interativa na área externa. Foto do autor, 2010.

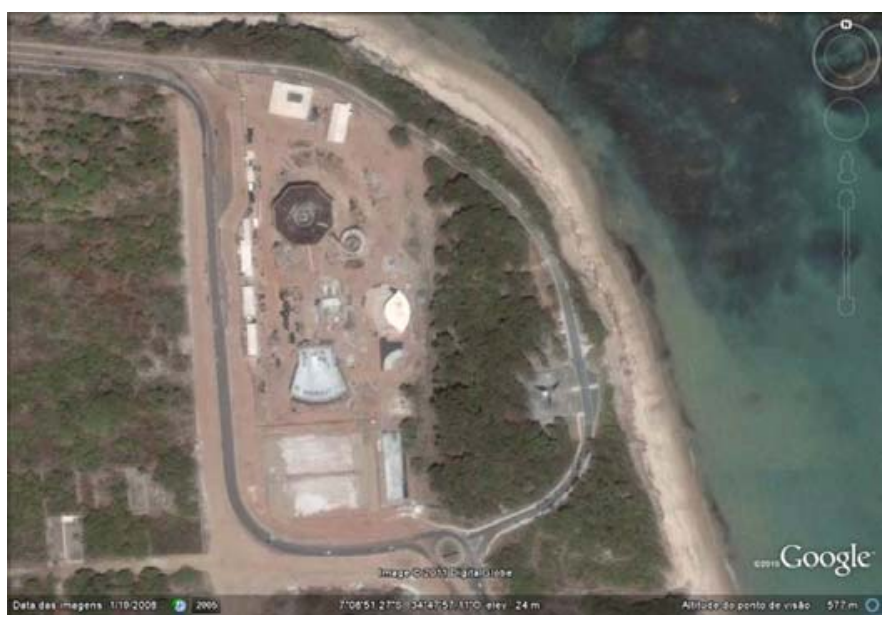

Fig. 90 - Foto aérea, antes da conclusão das obras. Google, 2008

O edifício principal apresenta tipologia formal, estrutural e de relação com o entorno muito semelhante ao MAC de Niterói. O edifício - desta vez octogonal e não circular, com "diâmetro" de 43m,- é suportado por uma estrutura cilíndrica central com 15m de diâmetro inserida num espelho d'água, com suas lajes em balanço. Os pavimentos superiores são acessados por uma rampa curva. O 
conjunto se localiza no alto de um platô, e o edifício principal apresenta uma bela vista em todas as direções tanto nos pavimentos de exposição quanto no terraço da cobertura. Parte dessa vista dá para o oceano.

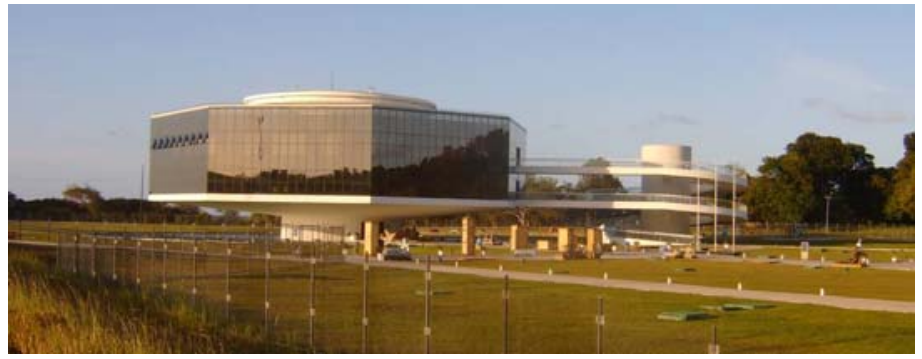

Fig. 91 - Edifício principal. Foto do autor, 2010.

Embora em Niterói Niemeyer tivesse um terreno menor, fica claro que ele optou por implantar o edifício na posição mais avançada da península. Na Estação Cabo Branco o terreno era menos proeminente, mas, novamente, recuar o edifício em relação ao mar é claramente intencional.

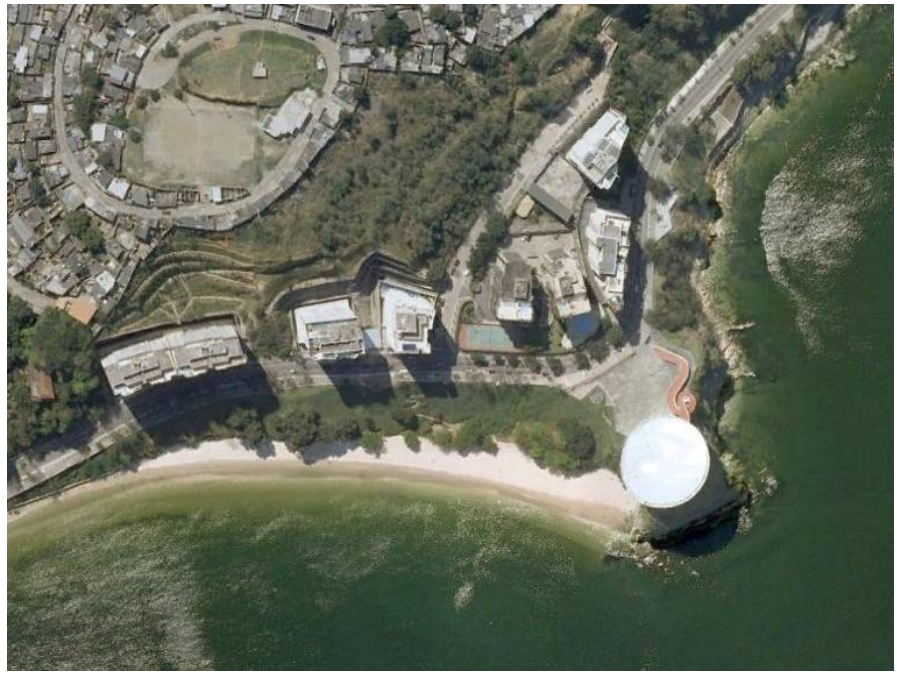

Fig. 92 - Vista aérea da implantação do MAC de Niterói, para comparação. Google, 2008.

Parece-nos que a implantação do edifício principal da Estação é menos feliz que a do MAC, e o edifício octogonal apresenta um aspecto muito pesado, em contraste com a leveza da obra de Niterói. 


\section{DISCUSSÕES}

\subsection{Comparações}

De forma geral, os centros de ciências estrangeiros estudados são maiores, mais completos e mais avançados do que os brasileiros. Recebem mais recursos - e, pelo menos no caso americano e britânico, são também menos reticentes com relação a fontes suplementares de renda - eventos, aluguel do espaço, exposições blockbusters, etc.

Os mais típicos science centers estudados são a Cité, o Nemo, o Exploratorium, a Estação Ciência, o Sabina e o Catavento. A Academia e o MCT têm a peculiaridade de serem também instituições de pesquisa, com rico acervo na área de história natural.

Várias são as abordagens comparativas possíveis. É mais ou menos equilibrado o número de museus estudados que construíram novas sedes em relação aos que adaptaram edifícios existentes. A esses edifícios existentes podem ser ou não atribuídos valores históricos: o Cosmocaixa, o CienTec, a Estação Ciência e o Catavento foram reconvertidos, enquanto a Cité apenas aproveitou a estrutura préexistente, por motivos econômicos.

Muitos deles são inseridos em parques ou em áreas verdes preservadas: no Brasil o CienTec, o Espaço Ciência, o Sabina, a Estação Cabo Branco; no exterior a Cité, em alguma medida o Rose Center (ainda que bastante central), o MIM, e a Academia.

Instituições como o CienTec e o Espaço Ciência aproveitaram essa inserção para desenvolver atividades e exposições nas áreas externas. Além disso, são caracterizados por terem diversos edifícios espalhados no parque, e não um pavilhão único. Nesse sentido, são semelhantes também ao MIM. 
Mas a abordagem da Academia, intencionalmente abrindo-se para os belos visuais do parque, é única, assim como o aspecto geral de transparência e luz natural abundante. A Academia é também a única instituição com uma abordagem ecológica explícita, que inclui o próprio edifício como exposição, ainda que os recursos utilizados não sejam necessariamente revolucionários, mas representem uma preocupação contemporânea e um gesto simbólico.

Os biomas naturais reproduzidos pela Academia e pela Cosmocaixa são muito interessantes e bem-concebidos. No caso da Cosmocaixa a selva amazônica pode ser observada em detalhes, tanto em seu aspecto terrestre quanto aquático. Em ambos os casos, nos parece que foi levada a cabo uma evolução do conceito de diorama, na qual os ambientes criados não mais simulam uma realidade, mas de fato, a reconstroem.

Explorando ainda o tema da museologia, o Rose Center é exemplar. A esfera é plenamente utilizada, sua metade superior como planetário, e sua metade inferior como uma espécie de cinema especial, que representa o Big Bang. Além disso, a exposição helicoidal do Cosmic Pathway é exemplo bem sucedido de integração entre arquitetura e museologia, assim como da relação entre forma e função. Sob o aspecto arquitetônico, o projeto tem uma imagem muito forte e a própria construção física, estrutural, da esfera, é um feito considerável e sua inserção no cubo de vidro, com a entrada em arco, muito bem resolvida.

Com sua aparência de navio, a outra instituição cuja estrutura apresenta interesse é o Nemo. Não por sua expressividade, mas pela solução técnica decorrente das circunstâncias. Ele teve que aproveitar parte das fundações do túnel sobre o qual foi construído, apresentando estrutura mista: a principal é de concreto, e a da "proa" é uma gaiola metálica.

Tanto o Nemo quanto a Academia apresentam, com suas formas características, potencial para se constituir em elementos marcantes urbanos. Entretanto, sem 
dúvida o Nemo, com sua localização central e proeminente nas docas de Amsterdã, acaba por concretizar esse potencial muito mais do que a Academia, inserida num cenário mais bucólico. Outro fato arquitetônico a se destacar no Nemo é sua cobertura acessível aos pedestres, uma espécie de praça de onde se tem uma vista panorâmica de Amsterdã. É interessante que na Academia, do mesmo Piano, a cobertura também é um elemento fundamental do conjunto: o grande plano vegetal no qual brotam os topos das esferas como pequenas colinas é que dá força à sua forma geral, que, de outro modo, seria um simples paralelepípedo com generosos beirais.

Tanto o MIM quanto o edifício original do Espaço Ciência apresentam um aspecto de desmaterialização como as Cavernas de Altamira, ao se fundirem com os taludes gramados que os envolvem. De forma geral, o conjunto do MIM apresenta espaços interiores, arranjos formais e elementos arquitetônicos muito bem resolvidos.

Algumas das instituições estudadas tinham implícito ou explícito em sua criação a intenção de dinamizar o entorno: a Cité, o Nemo, o Catavento. Outros tiveram impacto urbano diferente, como a Estação Ciência, que passou a atrair jovens carentes que já circulavam pela região, sendo absorvidos por programas de inclusão social da instituição. Ela talvez seja, com exceção do Rose Center, o museu estudado na dissertação mais centralmente localizado na cidade, o que implica numa grande facilidade de acesso para os visitantes - mas também na grande dificuldade de ampliação, como comentado no Capítulo 5, tópico 5.4, e refletido nos projetos da Cafeteria e da Estação Natureza.

O maior centro de ciência brasileiro é o MCT da PUC de Porto Alegre. O edifício, como no caso dos mais recentes do Espaço Ciência, foi construído especificamente para sua função. Apresenta interiores de exposição bastante interessantes, mas espaços exteriores bem pior sucedidos. O ponto forte é a grande variedade e qualidade das exposições - em parte possibilitada pela diversidade dos espaços 
arquitetônicos - e a boa infra-instrutora de manutenção, que faz com que o museu tenha um aspecto profissional e competente. Condição semelhante tem o Catavento, com uma massa crítica de boas exposições interativas - ainda que as tecnológicas tendam mais para a espetacularização -, e a quantidade de recursos financeiros e humanos investida, que, sem dúvida, também contribuem para a sua qualidade. Entretanto, a solidez do MCT - ligado à PUCRS - já foi comprovada pelo tempo. Quanto ao Catavento, é dependente de vontades políticas que podem variar com o vento...

Alguns comentários pontuais devem ser feitos. A escolha do Exploratorium se deu em virtude da influência que teve em todo o mundo com sua ênfase absoluta em experimentos interativos, além de nos remeter mais uma vez à história das feiras mundiais, por ocupar um pavilhão construído especialmente para uma delas, a de 1915. O Carnegie Science Center foi incluído apenas como desculpa para discutir alguns conceitos apresentados no projeto por Tschumi : o espaço intermediário entre o novo e o velho, a idéia do edifício como elemento marcante (derivada de Lynch) e o conceito ingênuo de um centro de ciências revolucionário - que era, na verdade, já tradicional.

Os maiores destaques do Sabina e da Estação Cabo Branco são os nomes de seus arquitetos: qualquer projeto de Paulo Mendes da Rocha e Oscar Niemeyer desperta interesse. Em particular, a Estação de Niemeyer apresenta relevância por ser uma nova interpretação da tipologia formal criada por ele mesmo no MAC de Niterói. Outro fato curioso é a aparente influência do nome criado por Washington Olivetto - Estação -, que vai se tornando sinônimo de centro de ciências no Brasil... 


\subsection{A esfera: um tema recorrente}

Conforme observado no Capítulo 6, tópico 6.1.1, Fainsilber desejou com a Géode concretizar uma tipologia formal que só existira antes como idéia: a esfera. Mas formas intermediárias existiram há muitos séculos: as cúpulas, semi-esféricas como - Panteão romano ou ogivais como as cúpulas góticas ou a própria cúpula de Brunelleschi em Santa Maria del Fiore.

“Vasari foi o primeiro a observar que cúpula de Santa Maria del Fiore não devia ser relacionada apenas ao espaço da catedral e respectivos volumes, mas ao espaço de toda a cidade, ou seja, a um horizonte circular $[\ldots]^{\prime \prime}{ }^{1}$. A idéia pode ser expandida para qualquer cúpula. Sob o aspecto simbólico, para qualquer cúpula mesmo; sob o aspecto visual, desde que haja horizonte livre e a cúpula seja vista de diversos locais, e preferencialmente à distância. A cúpula apresenta, portanto, “um simbolismo cósmico e religioso" 2, e "é justamente a representação do espaço em sua totalidade" 3 .

A "idéia da arquitetura como mostra de tecnologia avançada" está presente, no gótico, na cúpula de Brunelleschi, e muitos séculos depois na cúpula geodésica de Buckminster Fuller ${ }^{4}$.

Mas foi com Etienne-Louis Boullée, sob o lluminismo, que nasceu a idéia de construir a esfera arquitetônica. Ele projetou um monumento fúnebre - o Cenotáfio - em homenagem a Isaac Newton, que se constituía simplesmente numa esfera, pois só esse volume "parecia um meio adequado de expressar o Todo em termos arquitetônicos" ${ }^{5}$. Numa das versões do projeto seriam feitos finos canais na esfera

\footnotetext{
${ }^{1}$ ARGAN, 2005, p. 95.

${ }^{2}$ Ibidem, p. 95.

${ }^{3}$ Ibidem, p. 96.

${ }^{4}$ Ibidem, p. 99.

${ }^{5}$ GÖSSEL; LEUTHÄUSER, 1996, p. 11.
} 
que permitiriam a entrada de luz durante o dia, compondo um "céu estrelado" algo como um planetário ${ }^{6}$. O projeto nunca chegou a ser executado.

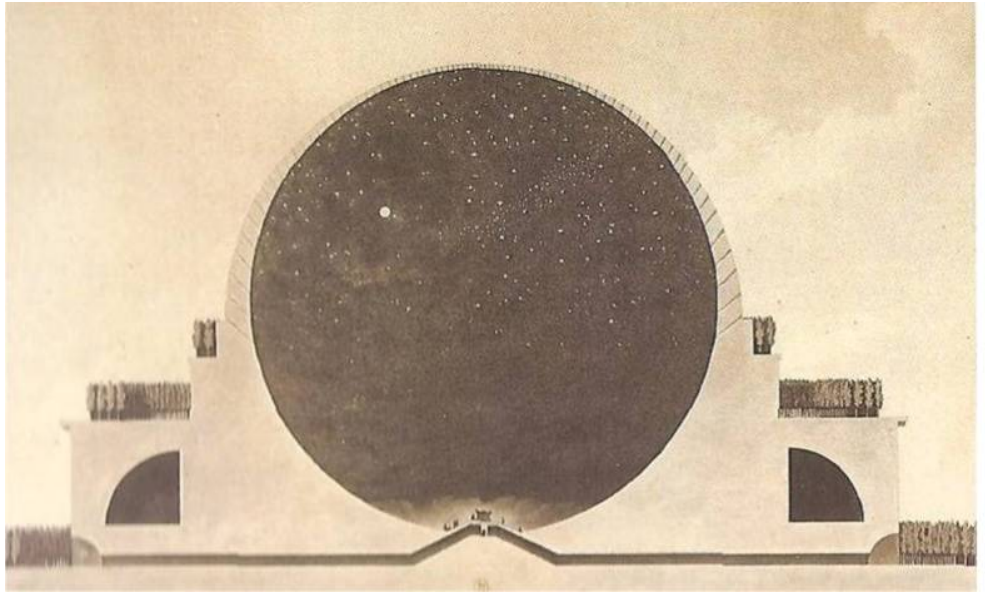

Fig. 92 - Cenotáfio de Boullée. Projeto. Corte. GÖSSEL; LEUTHÄUSER, 1996, p. 13.

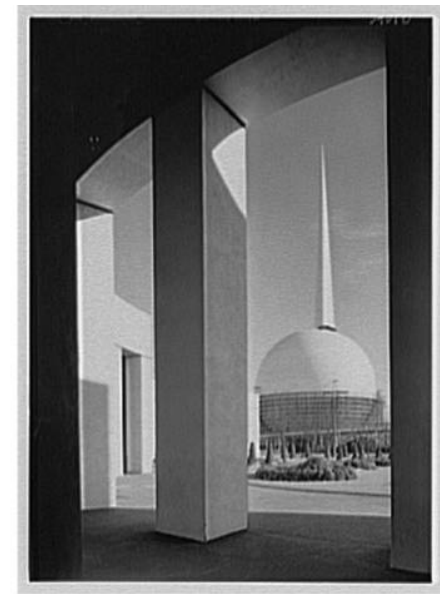

Fig. 93 - Feira mundial de 1939, em Nova Iorque. Ao fundo, a Perisphere. Wikipedia, 2010.

Na mesma feira mundial de 1939, em Nova Iorque, na qual o Brasil foi representado pelo pavilhão projetado por Oscar Niemeyer e Lúcio Costa, foi construído por Wallace K. Harrison o "Perisphere" 7, uma esfera de $55 \mathrm{~m}$ de diâmetro que abrigava um diorama chamado "Democracity", representando uma cidade ideal futurística. Ao sair da esfera, descia-se por uma rampa espiral de 290 $\mathrm{m}$ de comprimento ${ }^{8}$.

Em outra feira mundial, a de 1967, em Montreal, o pavilhão norte-americano era uma esfera incompleta geodésica - a Biosphere - com autoria de Buckminster Fuller $^{9}$. A estrutura foi mantida e transformada posteriormente em museu.

Depois de Fainsilber ter concebido o seu projeto, mas antes de vê-lo concluído, o complexo Disney inaugurou o Epcot Center, incluindo um edifício que é na verdade a primeira esfera arquitetônica completa permanente, a chamada Spaceship Earth, em 1982. Foi baseada nas estruturas de Fuller. Em nosso entendimento, ela não

\footnotetext{
${ }^{6}$ GÖSSEL; LEUTHÄUSER, 1996, p. 13.

${ }^{7}$ FUTAGAWA, 2000, p. 48.

${ }^{8}$ WIKIPEDIA, 2010.

${ }^{9}$ A VIEW, 2010.
} 
deve ser menosprezada apenas por ter sido criada para um parque de diversões sem dúvida associado à espetacularização.

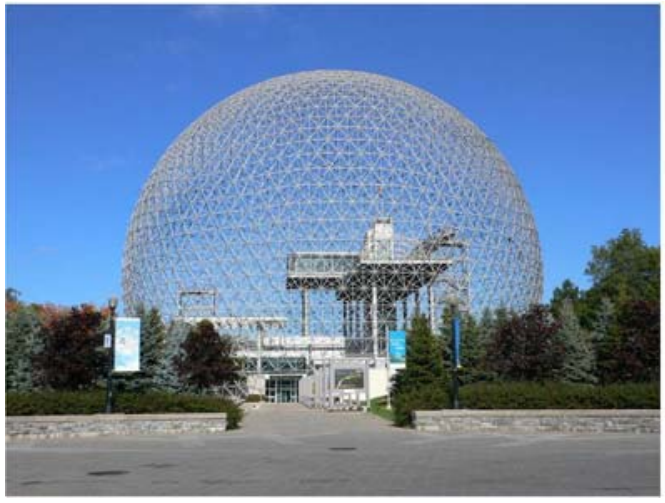

Fig. 94 - Biosphere. Construída para a Feira Mundial de 1967, em Montreal, Canadá. A estrutura foi mantida e transformada em museu da água em 1964. Foto atual, Wikimedia Commons.

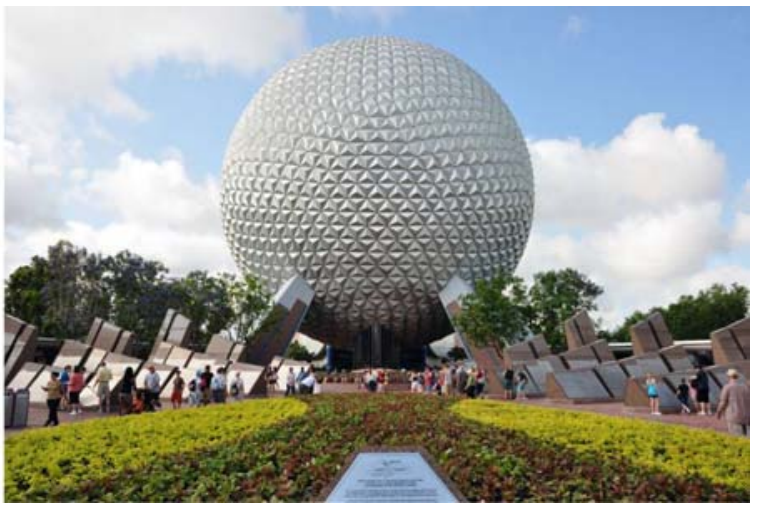

Fig. 95 - Spaceship Earth, Epcot Center, Orlando, EUA. Foto atual, Wikimedia Commons.

Se compararmos a Géode (ver fig. 07, p. 146) com o Rose Center, (ver figs. 27, 29 e 31, a partir da p. 169) veremos que este último é, como a Spaceship Earth, uma esfera completa, enquanto a Géode é achatada na base.

Ainda que as esferas sejam mais raras, as cúpulas semi-esféricas estão presentes na grande maioria dos centros de ciências do mundo. Além do significado simbólico e da força expressiva de sua volumetria, a semi-esfera responde perfeitamente a uma função: a projeção da abóbada celeste dos planetários, ou ainda as projeções dos dome theaters - cinemas esféricos -, como é caso da Géode. Esta é uma situação específica em que, de fato, a forma segue a função, quase inexoravelmente.

Seria possível, por exemplo, Polshek ter escondido a esfera do Rose Center do observador externo - bastaria não fazer o fechamento em vidro, mas em metal, madeira ou alvenaria. Poderia também escondê-la do visitante interno: construiria lajes que nela encostassem, rearranjaria os espaços interiores. Entretanto, isso não faria o menor sentido, depois do esforço técnico para conseguir construí-la com 
aquela forma específica, com a simbologia que lhe acompanha - que é a mesma da cúpula, e do círculo.

No caso dos planetários, tanto a função como a simbologia é perfeita, considerando, conforme se disse acima, que a cúpula (e, por conseqüência, a esfera) é "a representação do espaço em sua totalidade" ${ }^{10}$.

Polshek casa o céu religioso da cúpula das catedrais com o céu físico da astronomia quando afirma que gostaria que o Rose Center fosse uma "catedral cósmica" ${ }^{11}$.

\footnotetext{
${ }^{10}$ ARGAN, 2005, p. 96.

${ }^{11}$ SIREFMAN, 2000, p. 42.
} 


\section{CONCLUSÕES}

Apesar de iniciarmos a dissertação procurando diferenciar nosso tema - os centros de ciências e tecnologia - ao longo do desenvolvimento da pesquisa e da análise das instituições, vimos que, como afirmam vários autores (ver Capítulo 1), essas diferenças vêm se reduzindo ao longo do tempo.

Os museus científicos parecem tender a abranger cada vez mais temas, muitas vezes multidisciplinares ${ }^{1}$. Segundo Wagensberg, a prioridade do museu é a realidade, "é o fenômeno, e para entendê-lo se usa física, matemática, química" 2.

Padilla sugere um centro de ciências com tema na sociedade local e sua cultura, em torno das relações entre ciência e tecnologia, arte, e entre o histórico e o contemporâneo: "escolher linhas e enfoques temáticos que permitam experiências integradas e aprendizagens que se reforcem entre si [...] será a característica inicial de um novo tipo de centro de ciências" ${ }^{3}$.

A California Academy of Science por exemplo, além de sua coleção de história natural, incluiu planetário e biomas em sua nova sede, de 2008. O American Museum of Natural History, na constituição do Rose Center, desenvolveu temas relacionados com a Astronomia e com o estudo de nosso Planeta.

A postura da instituição priorizando o visitante e seus conhecimentos prévios, suas particularidades, é uma tendência contemporânea que deve permanecer ${ }^{4}$ - e concomitantemente a isso, é possível dizer que dificilmente um museu elitista sobreviverá. Assim, o desafio que se coloca é atingir o equilíbrio entre uma postura que consiga atingir um público diversificado sem perder de vista os valores e a consistência de seus conteúdos.

\footnotetext{
${ }^{1}$ SCHAUBLE; BARTLETT, 1997, p. 786-787.

${ }^{2}$ WAGENSBERG, 2003, p. 17.

${ }^{3}$ PADILLA, 2001, p. 134.

${ }^{4}$ RODARI; MERZAGORA, 2007, p. 2; VAN PRAET, 2005, p. 351.
} 
Se, por um lado, instrumentos de inclusão e participação social como o engajamento do público em questões científicas, debates e fóruns, em ambiente real ou virtual parecem ter vindo para ficar, o mesmo acontece com as exposições espetaculares, os financiamentos das instituições através do aluguel de seu espaço e por vezes de sua imagem - com o perigo da perda de independência curatorial. Quando o lazer e a entretenimento estão associados à educação ${ }^{5}$ é importante ter o cuidado de evitar que eles sejam vazios de significado e alienantes.

Quando o tema são as novas tecnologias e o virtual, equilíbrio parece ser a palavra chave. A informática, a internet, todos os demais avanços tecnológicos vieram para ficar. Cabe a nós utilizarmos essas ferramentas de forma adequada em nossas instituições, jamais como fins em si mesmas, mas como instrumentos de participação e apoio para o fenômeno perene, antigo, da comunicação. “Um dos desafios impostos aos museus é o desenvolvimento de estratégias de comunicação que, ao mesmo tempo, mantenha o entusiasmo pela instituição para o visitante real e promova uma aproximação dos grupos tradicionalmente excluídos" ${ }^{6}$.

As exposições contemporâneas serão mais bem sucedidas se utilizarem diversos suportes $^{7}$, incluindo objetos reais e/ou originais ${ }^{8}$. Para que um museu de ciências promova uma formação completa, que represente uma autêntica cultura científica e técnica, ele deve incluir em suas exposições as perspectivas históricas, didáticas, e de divulgação, incluindo o objeto original, quando possível, com a riqueza que sua fruição proporciona ${ }^{9}$.

Se considerarmos a importância essencial do espaço interior na arquitetura, conforme entendido por Zevi e diversos outros autores (ver Capítulo 5, tópico 5.3), fica clara a relevância de se estudar, num trabalho como esse, a museologia, as

\footnotetext{
${ }^{5}$ CRESTANA, 2001, p. 627.

${ }^{6}$ VALENTE; CAZELLI; ALVES, 2005, p. 196-197.

${ }^{7}$ CHELINI; LOPES, 2008; VAN PRAET; DAVALLON; JACOBI, 2005; CURY, 2005.

${ }^{8}$ WAGENSBERG, 2005a, p. 1; MENEZES, 2007.

${ }^{9}$ GIL, 1988, p. 83 e 87; RODARI; MERZAGORA, 2007, p. 2.
} 
posturas educacionais, a eficácia da interatividade, as características gerais das instituições, suas necessidades programáticas, pois elas ajudam a definir esse espaço.

A relação entre a arquitetura e a exposição poderá se dar em maior ou menor grau. Apesar das ressalvas contidas no Capítulo 4, tópico 4.3, sobre os perigos do excessivo comprometimento entre uma exposição e um espaço arquitetônico especialmente construído para ela, o belíssimo resultado obtido no conjunto do Rose Center (ver Capítulo 6, tópico 6.1.4) nos convence de que vale a pena correr o risco.

Cada vez mais a implantação de museus tem sido utilizada como estratégia de requalificação urbana, conforme citado no Capitulo 2, tópico 2.1.7. Essas ações muitas vezes são bem-sucedidas, como nos casos do Centro Georges Pompidou, do Guggenhein de Bilbao, da Cité e do Nemo. Coincidência ou não, em todos esses casos os edifícios tinham suficiente imagibilidade para se constituírem em elementos marcantes, marcos urbanos (ver Capítulo 5, tópico 5.3), muitos deles se encaixando perfeitamente na posição tipológica do "organismo extraordinário" de Montaner (ver Capítulo 5, tópico 5.2). Segundo Zevi, os edifícios ajudam a compor, em qualquer situação, o espaço urbanístico.

Embora haja diversas posições sobre a relação entre forma e função na arquitetura (ver Capítulo 5, tópico 5.3), o que nos chamou a atenção no desenvolvimento da dissertação foi a quase inevitável aparição de cúpulas semi-esféricas e esferas nos centros e museus de ciências. A cúpula responde diretamente aos planetários e aos cinemas esféricos. A esfera representa, sem dúvida, um desejo formal, tecnológico e, possivelmente, simbólico.

A maior parte das instituições estudadas - notadamente aquelas fora do Brasil não foram pessoalmente visitadas, e, portanto, para sua análise nos baseamos em representações, desenhos, imagens e textos. Essa é uma questão muito forte em 
Zevi, segundo o qual, em arquitetura, a representação nunca é suficiente, pois o espaço - sua essência - é impossível de ser representado (ver Capítulo 5, tópico 5.3). Seguindo essa linha de raciocínio, nossa interpretação seria, necessariamente, imprecisa.

Entretanto, como visto no Capítulo 3, tópico 3.1, a tecnologia de realidade virtual está evoluindo. Parece-nos bastante razoável imaginar que, dentro em breve, será possível ter uma experiência "quase-arquitetônica" com esse tipo de recurso, no qual não só as imagens, sons e, possivelmente, cheiros, sejam produzidos, mas também as relações de escala entre o observador e a obra se mantenham.

Ainda muito longe dessa qualidade, mas representando um passo interessante, é a plataforma Google Earth, disponível gratuitamente na internet, na qual todo o Planeta, com sua topografia, é representado por fotos aéreas, nas quais se inserem imagens e informações diversas, assim como maquetes eletrônicas de muitos dos edifícios. Todas as instituições estrangeiras estudadas tinham maquetes incluídas nessa plataforma. Em especial a da California Academy of Science nos pareceu muito bem elaborada, motivo pelo qual a incluímos como exemplo no Capítulo 6 , tópico 6.1.2.

Ao finalizar nossa pesquisa concluímos que todos os assuntos estudados foram importantes para compor um panorama geral dos centros e museus de ciência e tecnologia, e que esse objetivo foi alcançado.

O estudo dos diversos museus levou em conta a maioria dos temas pesquisados, tendo permitido levantar diversas questões institucionais, educacionais, sociais e arquitetônicas.

Entendemos que o presente trabalho poderá se constituir em relevante referência para o aprofundamento dos estudos subseqüentes sobre centros e museus de ciência e tecnologia. 


\section{REFERÊNCIAS}

AB'SÁBER, Aziz N. Espaços complementares de educação. In: CRESTANA, Silvério; CASTRO, Miriam G; PEREIRA, Gilson R. de M. (orgs). Centros e museus de ciência: visões e experiências: subsídios para um programa nacional de popularização da ciência. São Paulo, Saraiva, 1998. p. 26-31.

ADELMAN, L.; DIERKING, L. D.; ADAMS, M. Phase II: Summative Evaluation Final Report, Years $3 \& 4$, Girls at the Center, The Franklin Science Museum \& Girls Scouts of the U.S.A., relatório técnico, Annapolis, Md.: Institute for Learning Innovation, 2000.

ALLARD, Michel; LANDRY, Anik. O estado da arte da pesquisa sobre educação museal no Canadá. In: MARANDINO, M; ALMEIDA, A. M., VALENTE, M. E. A. Museu: lugar do público. 1. ed. Rio de Janeiro: FAPESP / Editora Fiocruz, 2009, p. 15-26.

ALMEIDA, Adriana Mortara. O contexto do visitante na experiência museal: semelhanças e diferenças entre museus de ciência e de arte. História, Ciências, Saúde - Manguinhos, Rio de Janeiro, v. 12, p. 31-53, 2005, Suplemento.

ALMEIDA, Carla; MASSARANI, Luisa (orgs.). Centros e Museus de Ciências do Brasil 2009. Rio de Janeiro, ABCMC: UFRJ, FCC, Casa da Ciência: FIOCRUZ, Museu da Vida, 2009, 232p.

ANDERSON, Peter. Before the Blueprint: Science Center Buildings. Washington, ASTC, 1991. 93p.

ANDRADE, Ana Maria Ribeiro de. Controvérsia política e complexidade tecnológica vão ao museu. In: VALENTE, Maria Esther Alvarez (org.). Museus de Ciência e 
Tecnologia: interpretações e ações dirigidas ao público. Rio de Janeiro: Editora Museu de Astronomia e Ciências Afins, 2007, p. 77-84.

ARGAN, Giulio Carlo. Sobre a Tipologia em Arquitetura (1963). In: NESBITT, Kate (org.). Uma Nova Agenda para a Arquitetura. São Paulo, Cosac Naify, 2006, p. 267-273.

ARGAN, Giulio Carlo. O significado da cúpula. In: História da arte como história da cidade. 5a ed. São Paulo, Martins Fontes, 2005, p. 95-103.

BACELLAR, Nely R. R. Estação Ciência: um novo espaço para a divulgação científica. In: CRESTANA, Silvério; CASTRO, Miriam G; PEREIRA, Gilson R. de M. (orgs). Centros e museus de ciência: visões e experiências: subsídios para um programa nacional de popularização da ciência. São Paulo, Saraiva, 1998, p. 144147.

BALDACCI, Alain. Parques temáticos e de entretenimento. In: CRESTANA, Silverio et al (org.). Curso para Treinamento em Centros e Museus de Ciência: Educação para a ciência. São Paulo: Editora Livraria da Física, 2001, p. 333-335.

BALMORI, Diana. Landscape Vs. Architecture. Landscape Architecture, v. 79, n. 1, p. 36-37, Jan. 1989.

BANHAM, Reyner. 'Luxe, calme et technicité'. The Architectural Review, v. 180, n. 1078, p. 31-39, Dec. 1986.

BARBOSA, Cátia Rodrigues. Museu de Ciência, a Estética e a Arte: relações com o ensino de ciências. In: CRESTANA, Silverio et al (org.). Curso para Treinamento em Centros e Museus de Ciência: Educação para a ciência. São Paulo: Editora Livraria da Física, 2001, p. 167-173. 
BARROS, H. G. de P. L. de. Quatro Cantos de Origem. Perspicillum, Museu de Astronomia e Ciências Afins, v. 6, n. 1, nov. 1992.

BELL, Larry. Engaging the Public in Technology Policy. A New Role for Science Museums. Science Communication, v. 29, n. 3, p. 386-398, mar. 2008.

BELLONI, Maria Luiza. A formação na sociedade do espetáculo: gênese e atualidade do conceito. Revista Brasileira de Educação, n. 22, p. 121-136, jan./fev./mar./abr. 2003.

BELTRÃO, Fátima. Estação Ciência: Próxima parada. A Construção, n. o 2039, p. 68, mar. 1987 (revista semanal, ano XL).

BENJ AMIN, Walter. A obra de arte na era da sua reprodutibilidade técnica. 1936. In: Magia e Técnica, Arte e Política (xérox). Edição, local, editora e data desconhecidas, p. 165-196.

BICUDO, Denise C.; FORTI, Maria C.; BICUDO, Carlos E. de M. (orgs.). Parque Estadual das Fontes do I piranga (PEFI): unidade de conservação que resiste à urbanização de São Paulo. São Paulo, Editora Secretaria do Meio Ambiente do Estado de São Paulo, 2002, 351p.

BITTENCOURT, José Neves. Por uma crítica iluminista da informação pura. In: SEMINÁRIO INTERNACIONAL “MUSEUS, CIÊNCIA E TECNOLOGIA”, 2006, Rio de Janeiro. Livro... BITTENCOURT, J osé Neves; BENCHETRIT, Sarah Fassa; GRANATO, Marcus (orgs.). Rio de Janeiro: Museu Histórico Nacional, 2007, p. 15-29.

BITTENCOURT, José Neves et al. Introdução. In: SEMINÁRIO INTERNACIONAL “MUSEUS, CIÊNCIA E TECNOLOGIA”, 2006, Rio de Janeiro. Livro... BITTENCOURT, J osé Neves; BENCHETRIT, Sarah Fassa; GRANATO, Marcus (orgs.). Rio de Janeiro: Museu Histórico Nacional, 2007, p. 11-14. 
BLACHE, Bernard. Comentários ( $A$ interação: objetos de ciência e tecnologia e o público). In: VALENTE, Maria Esther Alvarez (org.). Museus de Ciência e Tecnologia: interpretações e ações dirigidas ao público. Rio de Janeiro: Editora Museu de Astronomia e Ciências Afins, 2007, p. 117-119.

BLACHE, Bernard. Museus de ciência: espaços para experimentar e compreender o cotidiano. 2006. Entrevista concedida a Fernanda / Museu da Vida / Fiocruz. Disponível em: <http://www.museudavida.fiocruz.br/cgi/cgilua.exe/sys/start.htm?from $\% 5$ Finfo\% 5 Findex $=21 \&$ infoid $=851 \&$ sid $=201>$ Acesso em: 18 jul. 2010.

BLACHE, Bernard. Representative for Science and Technology. Disponível em: $<$ http://new.cimuset. net/index2.php?option=content\&task=view\&id=1\&pop=1\&pag e $=0>$. Acesso em 16 jun. 2010.

BRAGANÇA GIL, F.; LOURENÇO M. C. Que cultura para o século XXI? O papel essencial dos museus de ciência e técnica. CD Red-POP, 1999.

BREIER, Ana Cláudia Bôer; CABRAL, Cláudia Piantá Costa. Museu Infantil: Estudo de Caso sobre a Interatividade no Ambiente Museal. In: SEMINÁRIO INTERNACIONAL - MUSEOGRAFIA E ARQUITETURA DE MUSEUS, 2005, Rio de Janeiro. Anais... Rio de Janeiro: UFRJ , 2005, 1 CD-Rom.

BRUNO, Maria Christina Oliveira. Princípios gerais de museologia e comunicação museológica. In: CRESTANA, Silverio et al (org.). Curso para Treinamento em Centros e Museus de Ciência: Educação para a ciência. São Paulo: Editora Livraria da Física, 2001, p. 267-269.

BUCHANAN, Peter. New Metropolis. In: Renzo Piano Building Workshop. Vol. 4. London, Phaidon Press Limited, 2000, p. 36-55. 
BUEno, W. C. da C. Jornalismo Científico. Ciência e Cultura, v. 37, n. 9, p. 14201427, set. 1985 .

BURKE, Meg. It's Not Just About the Building. Curator, v. 51, n. 4, p. 345-347, Oct. 2008.

CAMERON, Fiona. Contentiousness and shifting knowledge paradigms: The roles of history and science museums in contemporary societies. Museum Management and Curatorship, v. 20, n. 3, p. 213-233, 2005.

CANAS, Adriano Tomitão. Arquitetura para Museus. São Paulo, 2004, 129p. Dissertação (Mestrado). Faculdade de Arquitetura e Urbanismo, Universidade de São Paulo.

CAZELLI, Sibele. O Perfil das Escolas e das Famílias que Promovem o Acesso dos Jovens aos $\quad$ Museus. $2006 . \quad$ Disponível em <http://www.casaruibarbosa.gov.br/dados/DOC/palestras/memo_info/mi_2006/FC RB_Memorialnformacao_SibeleCazelli.pdf>. Acesso em: 16 jul. 2010.

CHAGAS, Mário. Museus de Ciência: assim é se lhe parece. In: SEMINÁRIOS “O FORMAL E O NÃO-FORMAL NA DI MENSÃO EDUCATIVA DO MUSEU", 2001/2002, Rio de Janeiro. Livro... Rio de Janeiro: Museu da Vida: Museu de Astronomia e Ciências Afins (MAST), 2002, p. 46-59.

CHAGAS, Mário de Souza. Comentários (Museus, ciência, tecnologia e sociedade). In: VALENTE, Maria Esther Alvarez (org.). Museus de Ciência e Tecnologia: interpretações e ações dirigidas ao público. Rio de Janeiro, Editora Museu de Astronomia e Ciências Afins, 2007, p. 29-30. 
CHAGAS, Mario de Souza; STORINO, Claudia M. P. Os museus são bons para pensar, sentir e agir. MUSAS - Revista Brasileira de Museus e Museologia, Rio de Janeiro, n. 3, p. 6-8, 2007.

CHAMBERS, Marlene. Beyond 'Aha!': Motivating Museum Visitors. In: Association of Science - Technology Centers - ASTC. What Research Says about Learning in Science Museums. Washington, ASTC, 1990, p. 10-12.

CHELINI, Maria-Júlia Estefânia; LOPES, Sônia Godoy Bueno de Carvalho. Exposições em museus de ciências: reflexões e critérios para análise. Anais do Museu Paulista, São Paulo, N. Sér. v.16, n.2, p. 205-238, jul./dez. 2008.

CHESEBROUGH, David E. The Ongoing ASTC "New Models" Discussion. The Informal Learning Review, n. 75, p. 16-18, 2005.

CHESEBROUGH, David E. New Models: The Search for an Improved Approach to Science Centers and Museums. The Informal Learning Review, v.1, n. 74, p. 813, 2005. Disponível em: <http://www.informallearning.com/archive/Chesebrough74. htm>. Acesso em: 16 jul. 2010.

CIMUSET - International Commitee of Museums of Science and Technology, 2010 (homepage). Representative for Science and Technology. Disponível em: <http://www.cimuset.net/>. Acesso em: 16 jun. 2010.

COLQUHOUN, Alan. Tipologia e Metodologia de Projeto (1967). In: NESBITT, Kate (org.). Uma Nova Agenda para a Arquitetura. São Paulo, Cosac Naify, 2006, p. 273-283.

CROWE, Norman. Studies in Typology. Journal of Architectural Education (J AE), v. 38, n. 1, p. 10-13, Autumn, 1984.

CONTIER, Djana; MARANDINO, Martha. The Science, Technology, and Society-STS Movement in some Brazilian Science Museums. In: CONGRESSO MUNDIAL DE 
CENTROS DE CIÊNCIA, 5, 2008, Toronto, Ontário, Canadá. Disponível em < http://www.geenf.fe.usp.br/publica.php>. Acesso em: 4 nov. 2009.

CORBIOLI, Nanci. Construção aflora no parque como uma grande rocha suspensa. Revista Projeto Design, n. 330, ago. 2007. Versão digital resumida. Disponível em <www.arcoweb.com.br>. Acesso em: 22 jul. 2010.

COSTA, Lúcio. Arquitetura. 3ạ ed. Rio de Janeiro, José Olympio Ltda., 2005, 160p.

CURY, Marília Xavier. Exposição: concepção, montagem e avaliação. $1^{\mathfrak{a}}$ ed. São Paulo, Annablume, 2005, 162p.

CURY, Marília Xavier. Estudo sobre Centros e Museus de Ciências : subsídios para uma política de apoio. In: SEMINÁRIOS “O FORMAL E O NÃO-FORMAL NA DIMENSÃO EDUCATIVA DO MUSEU", 2001/2002, Rio de Janeiro. Livro... Rio de Janeiro: Museu da Vida: Museu de Astronomia e Ciências Afins (MAST), 2002, p. 60-69.

CURY, Marília Xavier. Estudo sobre centros e museus de ciências: subsídios para uma política de apoio. São Paulo, VITAE, 2000, 197p. (Relatório).

CRESTANA, Silvério. Subsídios para projetos de centros e museus de ciência. In: Curso para Treinamento em Centros e Museus de Ciência: Educação para a ciência. São Paulo: Editora Livraria da Física, 2001, p. 623-630.

DANILOV, Victor J. Science and Technology Centers. Massachusetts, The MIT Press, 1982, 355p.

DAVEY, Peter. Paris 200. Architectural Review, v. 186, n. 1.110, p. 27-29, Aug. 1989. 
DAVIES, Stuart. Plano Diretor. São Paulo, EDUSP, Fundação Vitae, 2001, 60p., 1v. Série Museologia: roteiros práticos.

DEPARTMENT for Culture, Media and Sport. Centres for Social Change: Museums, Galleries and Archives for All. London, DCMS, 2000.

DEMANT, David. O jogo da internet. In: VALENTE, Maria Esther Alvarez (org.). Museus de Ciência e Tecnologia: interpretações e ações dirigidas ao público. Rio de Janeiro: Editora Museu de Astronomia e Ciências Afins, 2007, p. 131-144.

DIERKING, Lynn D. Centros de Ciências: recursos valiosos para a Aprendizagem Familiar. In: MARANDINO, M; ALMEIDA, A. M., VALENTE, M. E. A. Museu: lugar do público. 1. ed. Rio de Janeiro: FAPESP / Editora Fiocruz, 2009, p. 77-94.

DIVULGAÇÕES do Museu de Ciências e Tecnologia. Programa de Estágios para Profissionais de Museus e Centros de Ciências VITAE - MCT-PUCRS. Porto Alegre, EDIPUCRS, n. 5, 2006, 277p.

DUCONSEILLE, Pierre. A impossibilidade da presença do objeto original e sua necessária substituição por artefatos. In: VALENTE, Maria Esther Alvarez (org.). Museus de Ciência e Tecnologia: interpretações e ações dirigidas ao público. Rio de Janeiro: Editora Museu de Astronomia e Ciências Afins, 2007, p. 61-68.

DURANT, John. Desafio no MIT: divulgar ciência para adultos. Após 2005. Entrevista concedida a Luisa Massarani / Museu da Vida / FioCruz. Disponível em <http://www. museudavida. fiocruz.br/cgi/cgilua. exe/sys/start. htm?infoid=1202\&sid $=201>$. Acesso em: 17 jul. 2008.

DUTTON, Hugh. An Integral Approach to Structure and Architecture. Perspecta, v. 31, p. 60-69, 2000. 
EISENMAN, Peter. O Pós-Funcionalismo. In: NESBITT, Kate (org.). Uma Nova Agenda para a Arquitetura. São Paulo, Cosac Naify, 2006, p. 97-101.

EISENMAN and Tschumi quit Carnegie Science Center competition. Architectural Record, p. 30., Mar. 2001.

ELLIS, Charlotte. Unused Abattoir Becomes a Bristling Science Museum. Architecture, v. 76, n. 9, p. 85-89, Sep. 1987.

FABIANO JUNIOR, Antonio Aparecido. Relações entre cidade e museus contemporâneos: Bilbao e Porto Alegre. Revista Risco, São Carlos, n. 9, p. 154167, 2009.

FALCÃO, Douglas. Instrumentos científicos em museus - em busca de uma pedagogia de exibição. In: VALENTE, Maria Esther Alvarez (org.). Museus de Ciência e Tecnologia: interpretações e ações dirigidas ao público. Rio de Janeiro: Editora Museu de Astronomia e Ciências Afins, 2007, p. 125-130.

FAYARD, P. La sorpresa da Copérnico: el conocimento gira alredor del público. Alambique - didáctica de las Ciencias Experimentales, n. 21, ano VI, p. 9-16, jul. 1999.

FEDERSONI JUNIOR, Pedro A. Parada Butantã: uma reflexão sobre a vida. In: CRESTANA, Silvério; CASTRO, Miriam G; PEREIRA, Gilson R. de M. (orgs). Centros e museus de ciência: visões e experiências: subsídios para um programa nacional de popularização da ciência. São Paulo, Saraiva, 1998, p. 148-159.

FEHER, E. Science Centers as Research Laboratories. In: Association of Science Technology Centers - ASTC. What Research Says about Learning in Science Museums. Washington, ASTC, 1990, p. 26-28. 
FIVE compete for science center. Architectural Record, p. 32, Feb. 2001.

FLEMING, David. Blockbuster Exhibitions - Why? ICOM conference, Seoul, 6 $\begin{array}{llll}\text { October } & 2004 . & \text { Disponível em }\end{array}$ <http://intercom. museum/conferences/2004/fleming2.html>. Acesso em: 16 jul. 2010.

FRAMPTON, Kenneth. Rappel a l'ordre: argumentos em favor da tectônica. In: NESBITT, Kate (org.). Uma Nova Agenda para a Arquitetura. São Paulo, Cosac Naify, 2006, p. 557-569.

FRIDMAN, Luis Carlos. Imagens e subversões. História, Ciências, Saúde Manguinhos, Rio de Janeiro, v.5, n.2, out. 1998. Disponível em <http://www.scielo.br/scielo.php?script=sci_arttext\&pid=S0104-

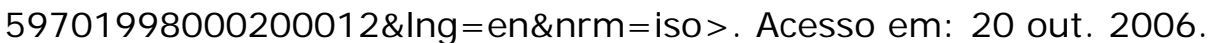

FUTAGAWA, Yukio. Polshek Partnership. Rose Center for Earth and Space, American Museum of Natural History. GA Document, n. 63, p. 48-57, Nov. 2000.

GARCIAS, Jean Claude. Les Folies Tschumi a La Villette. Domus, n. 703, p. 158161, 1989.

GARNETT, Robin (coord.). The Impact of Science Centers / Museums on their Surrounding Communities: Summary Report, 2001. Disponível em: <http://www.astc.org/resource/case/Impact_Study02.pdf>. Acesso em: 16 jul. 2010.

GASPAR, Alberto. Museus e Centros de Ciências: Conceituação e Proposta de um Referencial Teórico. S. Paulo, 1993, 173p. Tese (Doutorado, na área de Didática). Faculdade de Educação, Universidade de São Paulo. 
GIL, Fernando Bragança. Museus de ciência - preparação do futuro, memória do passado. Fundação Calouste Gulbenkian, 1988. Disponível em: <http://hdl.handle.net/123456789/124>. Acesso em: 10 ago. 2007.

GOLDENBERG, José. Museus de Ciências. In: CRESTANA, Silvério; CASTRO, Miriam G; PEREIRA, Gilson R. de M. (orgs.). Centros e museus de ciência: visões e experiências: subsídios para um programa nacional de popularização da ciência. São Paulo, Saraiva, 1998, p. 32-35.

GOROVITZ, Matheus. Considerações sobre a arquitetura de museus e suas tipologias. In: SEMINÁRIO INTERNACIONAL - MUSEOGRAFIA E ARQUITETURA DE MUSEUS, 2005, Rio de Janeiro. Anais... Rio de Janeiro, UFRJ, 2005, 1 CD-Rom.

GÖSSEL, Peter; LEUTHÄUSER, Gabriele. Arquitectura no Século XX. Colônia, Benedikt Taschen, 1996, 432p.

GOUVÊA, Guaracira. A revista Ciência Hoje das Crianças e práticas de leituras do público infantil. In: MASSARANI, Luisa (org.). O pequeno cientista amador: a divulgação científica e o público infantil. Rio de Janeiro: Vieira \& Lent: UFRJ, Casa da Ciência: FIOCRUZ, 2005, p. 47-57.

GOUVEIA, Inês; DOBEDEI, Vera. Memórias das pessoas, de coisas e de computadores: museus e seus acervos no ciberespaço. MUSAS - Revista Brasileira de Museus e Museologia, Rio de Janeiro, n. 3, p. 93-100, 2007.

GRANATO, Marcus; BRITO, Jusselma D. de; SUZUKI, Cristiane. Restauração do pavilhão, cúpula metálica e luneta equatorial de $32 \mathrm{~cm}$ - Conjunto Arquitetônico do Museu de Astronomia e Ciências Afins (MAST). Anais do Museu Paulista, São Paulo, v. 13, n. 1, p. 273-311, jan./jun. 2005.

GUARNIERI, W. R. C. Estação Ciência - um projeto comprometido com a vida: o projeto museológico. São Paulo, 1986, 17p., xérox. 
GUISASOLA, J.; MORENTIN, M.; ZUZA, K. School visits to science museums and learning sciences: a complex relationship. Physics Education, n. 40, p. 544-549, 2005.

HAMBURGER, Ernst W. Divulgação científica. In: CRESTANA, Silvério; CASTRO, Miriam G; PEREIRA, Gilson R. de M. (orgs.). Centros e museus de ciência: visões e experiências: subsídios para um programa nacional de popularização da ciência. São Paulo, Saraiva, 1998. p. 174-181.

HAMBURGER, Ernst W. A popularização da ciência no Brasil. In: CRESTANA, Silverio et al (org.). Curso para Treinamento em Centros e Museus de Ciência: Educação para a ciência. São Paulo: Editora Livraria da Física, 2001, p. 113-141.

HAMBURGER, Ernst W.; MATOS, Cauê (Orgs.). O desafio de ensinar ciências no século XXI. São Paulo: EDUSP, Estação Ciência, CNPq, 2000, 349 p.

HARRINGTON, Gregory C. A Letter from the Executive Director of the California Academy of Sciences. Curator, v. 51, n. 4, p. 343-344, 384A, 384B, 384C, Oct. 2008.

HEIN, George E. O dilema da Educação científica: como ensinar quando os visitantes apenas querem aprender. In: MARANDINO, M; ALMEIDA, A. M., VAlente, M. E. A. Museu: lugar do público. 1. ed. Rio de Janeiro, FAPESP / Editora Fiocruz, 2009, p. 63-76.

HENNES, Tom. The Open Museum. Curator, v. 51, n. 4, p. 349-354, Oct. 2008.

HENSLEY, John R. The Excluded Muses and Social Responsibility in Science Centers. Bulletin of Science Technology Society, v. 11, n. 2, p. 78-82, 1991. 
HISTÓRIA preservada, a serviço da Ciência. Design \& Interiores, n. 03, p. 226230, ago. 1987 (Suplemento encartado na Revista Projeto 102).

HORTA, Maurício. A natureza do século 21. Revista AU, n. 179, fev. 2009, p. 3647.

HOUAISS, Antônio. Fruição. In: Dicionário eletrônico Houaiss da Língua Portuguesa. Objetiva, 2001a, 1 CD-Rom (versão 1.0).

HOUAISS, Antônio. Transponder. In: Dicionário eletrônico Houaiss da Língua Portuguesa. Objetiva, 2001b, 1 CD-Rom (versão 1.0). HOWARTH, Charles H.; MEDRANO, Maeryta A. Architecture and Exhibits: A survey of infraestructure. Washington, ASTC, 1997. 55p.

IANINI, Ana Maria Navas et al. Pesquisa em Divulgação Científica: um Levantamento de Referenciais Teóricos Nacionais. In: ENCONTRO NACIONAL DE PESQUISA EM EDUCAÇÃO EM CIÊNCIA (ENPEC), no VI, 2007, Florianópolis. Disponível em: <http://www.geenf.fe.usp.br/conteudo/arquivo/divulgacaocientificaenpec2007.pdf> . Acesso em: 5 jul. 2010.

ICOM - International Council of Museums. Estatutes, 2007. Disponível em: <http://icom.museum/statutes.html>. Acesso em: 16 jun. 2010.

ICOM - International Council of Museums, 2010. Development of the Museum Definition according to ICOM Statutes (2007-1946). Disponível em: <http://icom.museum/hist_def_eng.html>. Acesso em: 04 ago. 2010. 
JACOMY, Bruno. Introdução. Instrumentos, máquinas e aparatos interativos de ciência e tecnologia exibidos nos museus. In: VALENTE, Maria Esther Alvarez (org.). Museus de Ciência e Tecnologia: interpretações e ações dirigidas ao público. Rio de Janeiro, Editora Museu de Astronomia e Ciências Afins, 2007, p. 15-24.

JENSEN, N. Children's Perceptions of Their Museum Environments: a Contextual Perspective. Chidren's Environments, v. 11, n. 4, p. 300-324, 1994.

J ONES, Peter Blundell. La Villette. Architectural Review, v. 186, n. 1.110, p. 5459, Aug. 1989.

JORDAN, Furneaux R. História da Arquitectura no Ocidente. Editorial Verbo, 1979, 349p.

JURY, Louise. It's a hit - but should the Science Museum showcase props from a Hollywood movie? 2003. Disponível em: <http://www.independent.co.uk/news/uk/this-britain/its-a-hit--but-should-thescience-museum-showcase-props-from-a-hollywood-movie-580119.html>. Acesso em: 16 jul. 2010.

KNOBEL, Marcelo; MURRIELLO, Sandra. A utilização de vídeos e jogos eletrônicos em uma exposição interativa: a experiência da NanoAventura. In: MASSARANI, Luisa (editora). Ciência e criança: a divulgação científica para o público infantojuvenil. Rio de Janeiro: Museu da Vida / Casa de Oswaldo Cruz / Fiocruz, 2008, p. 78-84.

KOSTER, Emlyn. The Relevant Museum: A Reflection on Sustainability. Museum News, May/June 2006, p. 67-70 \& 85-90. Disponível em <http://www.aamus.org/pubs/mn/MN_MJ 06_RelevantMuseum.cfm>. Acesso em: 16 jul. 2010. 
LAMBLA, Annie. The Exploratorium's Invisible Dynamics Project: Environmental Research as Artistic Process. Leonardo, v. 39, n. 4, p. 383-385, 2006.

LANNA, Ana L. D. (org.). Meio Ambiente: Patrimônio Cultural da USP. São Paulo, Editora da Universidade de São Paulo, 2003, 208p.

LARSON, Soren. A Design Crossing Time and Space: New York City's New Planetarium. Architectural Record, v. 187, n. 5, p. 105, may 1999.

LE GOFF, Jacques. Memória. In: GIL, Fernando (Ed.). Enciclopédia Einaudi Vol. 1: Memória-história. Direção de Ruggiero Romano. Porto, Imprensa Nacional - Casa da Moeda, 1997, p. 11-50.

LEMOS, Carlos A. C. Alvenaria Burguesa. 2aㅡ ed., São Paulo, Nobel, 1989, 162p.

LÉVY, Pierre. Cibercultura. São Paulo, Ed. 34, 2005.

LEWENSTEIN, B. V. Models of public communication of science and technology. Version 16, June 2003. Disponível em: <http://communityrisks.cornell. edu/BackgroundMaterials/Lewenstein2003.pdf> Acessado em: novembro $2005 . \quad$ Disponível em: <http://www.dgdc.unam.mx/Assets/pdfs/sem_feb04.pdf>. Acesso em 04 ago. 2010.

LYNCH, Kevin. A imagem da cidade. Lisboa, Edições 70, 1996, 208p.

LOPES, Maria Margaret. Por que História nos Museus e Centros de Ciências? In: MARANDINO, M; ALMEIDA, A. M., VALENTE, M. E. A. Museu: lugar do público. 1. ed. Rio de Janeiro: FAPESP / Editora Fiocruz, 2009, p. 199-210.

LOPES, Thelma. Ciência em Cena: Discutindo Ciência por meio do Teatro. In: Avaliação e estudos de públicos no Museu da Vida. Rio de Janeiro: Museu da Vida, 2003, p. 76-89. Disponível em: 
<http://www.museudavida.fiocruz.br/media/Cadernos-do-Museu-da-Vida2003. pdf>. Acesso em: 16 jul. 2010.

LORIERS, Marie-Christine. Tschumi's La Villette: a park of follies. Progressive Architecture, v. 64, n. 5, p. 26-27, 1983.

LOUREIRO, José Mauro Matheus. Museus de ciência, divulgação científica e hegemonia. Ciência da Informação, Brasília, v. 32, n. 1, p. 88-95, jan./abr. 2003

LUKE, J., DIERKING, L. Families Exploring Science Together Preliminary Evaluation Findings, Year One, The New Jersey State Aquarium, The Academy of Natural Sciences, The Franklin Science Museum \& The Philadelphia Zoo, Philadelphia, PA, relatório técnico, Annapolis, Md., Institute for Learning Innovation, 2000.

MACEDO, E. Currículo e competência. In: LOPES, A. C.; MACEDO, E. (orgs.). Disciplinas e integração curricular: histórias e políticas. Rio de Janeiro, DPA Editora, 2002, p. 115-143.

MANTOVANI, Marta S. M; MASSAMBANI, Oswaldo. Ciência e Tecnologia no Parque. São Paulo, EDUSP, 2004a, 136p.

MANTOVANI, Marta S. M; MASSAMBANI, Oswaldo. Parque CienTec - Parque de Ciência e Tecnologia da USP: Restauração do conjunto arquitetônico de importância histórica para abrigar atividades de difusão da ciência e da tecnologia. São Paulo, EDUSP, 2004b, 104p.

MARANDINO et al. A Educação Não Formal e a Divulgação Científica: o que pensa quem faz? In: IV ENCONTRO NACIONAL DE PESQUISA EM ENSINO DE CIÊNCIAS ENPEC, 2004, Bauru. Atas do IV Encontro Nacional de Pesquisa em Ensino de 
<http://paje.fe.usp.br/estrutura/geenf/public.htm\#art>. Acesso em: 24 jul. 2010.

MARANDINO, M. A Pesquisa Educacional e a Produção de Saberes nos Museus de Ciências. História, Ciência e Saúde - Manguinhos, Rio de Janeiro, v. 12, p. 161$181,2005$.

MARANDINO, M. (org.). Educação em Museus: a mediação em foco. 1. ed. São Paulo: Geenf / FEUSP, 2008, v. 1. 48 p.

MARQUES, Gil da Costa; NUNES, Cesar A. A. Ensino a distância - o uso da internet como apoio. In: CRESTANA, Silverio et al (org.). Curso para Treinamento em Centros e Museus de Ciência: Educação para a ciência. São Paulo, Editora Livraria da Física, 2001, p. 223-235.

MASCARENHAS, Sergio. A Ciência para tirar mistérios. In: CRESTANA, Silvério; CASTRO, Miriam G; PEREIRA, Gilson R. de M. (orgs.). Centros e museus de ciência: visões e experiências: subsídios para um programa nacional de popularização da ciência. São Paulo, Saraiva, 1998, p. 14-19.

MASON, Timothy. Gestão Museológica: Desafios e Práticas. São Paulo, EDUSP, Fundação Vitae, 2004. 96p., 7v. Série Museologia: roteiros práticos.

MASSAMBANI, Oswaldo; MANTOVANI, Marta S. M. Parque de Ciências da Terra e do Universo: um Centro de Ciências para São Paulo no Parque Estadual das Fontes do I piranga. In: HAMBURGER, Ernst W. (org. / coord.) Educação para a Ciência Curso para Treinamento em Centros e Museus de Ciência. São Paulo, SP. Editor J osé Roberto Marinho, Ed. Livraria da Física, 2001, 680p.

MASSARANI, Luisa. A Divulgação Científica no Rio de Janeiro: algumas reflexões sobre a década de 20. Rio de Janeiro, 1998. Dissertação (Mestrado). Escola de Comunicação, UFRJ . 
MASSARANI, Luisa. Divulgação científica: considerações sobre o presente momento. Revista Comciência, n. 100, 2008. Comemorativa. Disponível em < http: //www.comciencia. br/comciencia/handler. php?section $=8 \&$ edicao $=37 \& i d=440>$ . Acesso em: 18 jul. 2010.

MASSARANI, Luisa. Apresentação. In: MASSARANI, Luisa (org.). o pequeno cientista amador: a divulgação científica e o público infantil. Rio de Janeiro: Vieira \& Lent: UFRJ , Casa da Ciência: FIOCRUZ, 2005, p. 7-8.

MATSUKUMA, Marcos; LEITE, Ivo Ojeda. Divulgação científica da Estação Ciência pela Internet. In: CRESTANA, Silvério et al (org.). Curso para Treinamento em Centros e Museus de Ciência: Educação para a ciência. São Paulo: Editora Livraria da Física, 2001, p. 475-478.

MAURÍCIO, Luiz Alberto. Centros de Ciências: origens e desenvolvimento: Uma reflexão sobre o seu papel e possibilidades dentro do contexto educacional. São Paulo, 1992. 146p. Dissertação (Mestrado). Instituto de Física, Universidade de São Paulo.

MAYFIELD, Heather. Como o Museu de Ciências de Londres trabalha com os cientistas para destacar a pesquisa contemporânea, as pessoas que a fazem e os problemas que a cercam. In: VALENTE, Maria Esther Alvarez (org.). Museus de Ciência e Tecnologia: interpretações e ações dirigidas ao público. Rio de Janeiro: Editora Museu de Astronomia e Ciências Afins, 2007, p. 121-124.

MCMANUS, Paulette M. Uma palavra em seu ouvido... O que você quer dizer quando fala, ou pensa a respeito de Educação (formal e informal), Aprendizagem e Interação. In: MARANDINO, M; ALMEIDA, A. M., VALENTE, M. E. A. Museu: lugar do público. 1. ed. Rio de Janeiro: FAPESP / Editora Fiocruz, 2009, p. 47-62. 
MCNAMARA, P. A. Trying It Out. In: Association of Science - Technology Centers ASTC. What Research Says about Learning in Science Museums. Washington, ASTC, 1990, p. 13-15.

MELENDEZ, Fernando. Edifícios de inspiração moderna ocupam parque. Revista Projeto Design, n. 328, p. 42-49, jun. 2007.

MENEZES, Ulpiano T. Bezerra de. Os museus na era do virtual. In: SEMINÁRIO INTERNACIONAL "MUSEUS, CIÊNCIA E TECNOLOGIA", 2006, Rio de Janeiro. Livro... BITTENCOURT, José Neves; BENCHETRIT, Sarah Fassa; GRANATO, Marcus (orgs.). Rio de Janeiro: Museu Histórico Nacional, 2007, p. 49-70.

MEHRTENS et al. Demolição de galpões industriais na Mooca: descaso e impunidade. Minha Cidade, São Paulo, ano 08, n. 88, nov. 2007. Disponível em: <http://www.vitruvius.com.br/minhacidade/mc196/mc196.asp>. Acesso em: 16 dez. 2007.

MONTANER, J osep M. Arquitetura e Crítica. Barcelona, Gustavo Gili, 2007, 160p.

MONTANER, Josep M. Museus para o Século XXI. Barcelona, Gustavo Gili, 2003, $162 p$.

MONTANER, Josep M. Depois do Movimento Moderno. Arquitetura da Segunda Metade do Século XX. Barcelona, Gustavo Gili, 2001a, 272p.

MONTANER, Josep M. Tipo e estrutura. Eclosão e crise do conceito de tipologia arquitetônica. In: A modernidade superada. Arquitetura, arte e pensamento do século XX. Barcelona, Gustavo Gili, 2001b, p. 107-129.

MONTANER, Josep M. Museos para el nuevo siglo. Barcelona, Gustavo Gili, 1995, $192 p$. 
MORAIS, João Francisco Regis de. Filosofia da Ciência e da Tecnologia. Introdução Metodológica e Crítica. 9ạ ed., Campinas, Papirus, 2009, 181p.

MOREIRA, Fernando J oão de Matos. Uma reflexão sobre o conceito de público nos museus locais. MUSAS - Revista Brasileira de Museus e Museologia, Rio de Janeiro, n. 3, p. 101-108, 2007.

MORRIS, Chris. Importing 'hands-on' science into schools: the Light Works van programme. Physics Education, n. 25, p. 263-266, 1990.

MORRIS, Ellen K. Architectural Type and the Institutional Programme. J ournal of Architectural Education (J AE), v. 35, n. 2, p. 17-25, Winter, 1982.

MORRIS, Ellen K. Teaching History Typologically. Journal of Architectural Education (J AE), v. 34, n. 1, p. 27-28, Autumn, 1980.

MOTTA, Renata Vieira. Museu e cidade: o impasse dos MACs. São Paulo, 2009. 300p. Tese (Doutorado, na área de História e Fundamentos da Arquitetura e do Urbanismo). Faculdade de Arquitetura e Urbanismo, Universidade de São Paulo.

MUSEUMS and Galleries Comission. Planejamento de Exposições. São Paulo, EDUSP, Fundação Vitae, 2001a., 34p., 2v. Série Museologia: roteiros práticos.

MUSEUMS and Galleries Comission. Educação em Museus. São Paulo, EDUSP, Fundação Vitae, 2001b. 28p. 3 v. Série Museologia: roteiros práticos.

NAVAS, Ana Maria; CONTIER, Djana; MARANDINO, Martha. Controvérsia Científica, Comunicação Pública da Ciência e Museus no Bojo do Movimento CTS. Ciência \& Ensino, v. 1, número especial, nov. 2007.

NESBITT, Kate (org.). Uma Nova Agenda para a Arquitetura. São Paulo, Cosac Naify, 2006, 664p. 
OECHSLIN, Werner. Premises for the Resumption of the Discussion of Typology. Assemblage, n. 1, pp. 36-53, Oct., 1986.

OPPENhEIMER, F. The Exploratorium and other ways of teaching Physics. Physics Today, set. 1975, p. 9-13.

OSBORNE, Harold. Estética e Teoria da Arte. Uma introdução histórica. São Paulo, Editora Cultrix, s/ data (edição inglesa original 1968), 283p.

PADILLA, Jorge. Conceptos de museos y centros interactivos. In: CRESTANA, Silverio et al (org.). Curso para Treinamento em Centros e Museus de Ciência: Educação para a ciência. São Paulo: Editora Livraria da Física, 2001, p. 113-141.

PANESE, Francesco. O significado de expor objetos científicos em museus. In: VALENTE, Maria Esther Alvarez (org.). Museus de Ciência e Tecnologia: interpretações e ações dirigidas ao público. Rio de Janeiro, Editora Museu de Astronomia e Ciências Afins, 2007, p. 31-40.

PAVAN, Crodowaldo. Criando Oportunidades. In: CRESTANA, Silvério; CASTRO, Miriam G; PEREIRA, Gilson R. de M. (orgs.). Centros e museus de ciência: visões e experiências: subsídios para um programa nacional de popularização da ciência. São Paulo, Saraiva, 1998, p. 138-143.

PAVÃO, Antonio Carlos; LEITÃO, Angela. Hands-on? Minds-on? Hearts-on? Socialon? Explainers-on! In: MASSARANI, Luisa; MERZAGORA, Matteo; RODARI, Paola (orgs.). Diálogos \& ciência: mediação em museus e centros de Ciência. Rio de Janeiro: Museu da Vida / Casa de Oswaldo Cruz / Fiocruz, 2007, 92p. 
PEREIRA, Sonia Gomes. A historiografia da arquitetura brasileira no século XIX e oS conceitos de estilo e tipologia. Estudos I bero-Americanos. V. XXXI, n. 2, p. 143154, dez. 2005.

PEVSNER, Nikolaus. Os pioneiros do desenho moderno. De William Morris a Walter Gropius. 2ª ed., São Paulo, Martins Fontes, 1995, 242p.

POMIAN, Krzysztof. Colecção. In: GIL, Fernando (Ed.). Enciclopédia Einaudi Vol. 1: Memória-história. Direção de Ruggiero Romano. Porto, Imprensa Nacional Casa da Moeda, 1997, p. 51-86.

PRANZETTI, Dirce Maria Freitas; COSTA, Maria Cecília Toloza CAde Oliveira e. Populações excluídas. In: CRESTANA, Silvério et al (org.). Curso para Treinamento em Centros e Museus de Ciência: Educação para a ciência. São Paulo, Editora Livraria da Física, 2001, p. 185-187.

QUIN, M. What is hands-on Science, and where can I find it? Physics Education, n. 25, p. 243-246, 1990.

RAW, Isaias. Ensino de ciências e ensino experimental. In: CRESTANA, Silvério; CASTRO, Miriam G; PEREIRA, Gilson R. de M. (orgs.). Centros e museus de ciência: visões e experiências: subsídios para um programa nacional de popularização da ciência. São Paulo, Saraiva, 1998, p. 74-79.

RENZO Piano Building Workshop. California Academy of Sciences. San Francisco, California, USA 2008. A + U, v. 463, n. 09:04, p. 20-47, Jul. 2008.

RENZO Piano Building Workshop. New Metropolis. Amsterdam, The Netherlands. Architectural Design, n. 67, p. II-V, Nov./Dec. 1997. 
RICHARDS, Anthony. Teatro, mediadores, Cientistas Punk e visitas-guiadas: os altos e baixos da interpretação ao vivo no Science Museum de Londres. In: WORKSHOP SUL-AMERICANO \& ESCOLA DE MEDIAÇÃO EM MUSEUS E CENTROS CIÊNCIA, 2008, Rio de Janeiro. Livro... MASSARANI, Luisa; ALMEIDA, Carla (editores). Rio de Janeiro: Museu da Vida / Casa de Oswaldo Cruz / Fiocruz, 2008, p. $133-142$.

ROCCA, Alessandro. Urban Surrealism: A Green Box in the Bay of Amsterdam. Lotus I nternational, v. 95, p. 6-21, 1997.

RODARI, Paola; MERZAGORA, Matteo. The role of science centres and museums in the dialogue between science and society. Journal of Science Communication, v. 6, n. $2,2007$.

RODRIGUES, Eduardo; MACHADO, Lúcio G. Arquitetura, Centros de Ciência e Preservação de Patrimônios Históricos. In: CRESTANA, Silvério; CASTRO, Miriam G; PEREIRA, Gilson R. de M. (orgs). Centros e museus de ciência: visões e experiências: subsídios para um programa nacional de popularização da ciência. São Paulo, Saraiva, 1998, p. 168-173.

SAAD, Fuad Daher. Centros de ciências: as atuais vitrinas do mundo da difusão científica. In: CRESTANA, Silvério; CASTRO, Miriam G; PEREIRA, Gilson R. de M. (orgs). Centros e museus de ciência: visões e experiências: subsídios para um programa nacional de popularização da ciência. São Paulo, Saraiva, 1998, p. 20-25.

SANDELL, Richard. Social inclusion, the museum and the dynamics of sectoral change. Museum and Society, v. 1, n. 1, p. 45-62, 2003.

SAN FRANCISCO'S Science Project: Renovating the Exploratorium. Architectural Record, v. 186, n. 7, p. 38, jul. 1998. 
SANTO, Marcelo et al. Práticas de Propriedade Intelectual na Red-Pop. In: Avaliação e estudos de públicos no Museu da Vida. Rio de Janeiro: Museu da Vida, 2003, p. 90-100. Disponível em: <http://www.museudavida.fiocruz.br/media/Cadernos-do-Museu-da-Vida2003.pdf>. Acesso em: 16 jul. 2010.

SANTOS, Paulo M. Instituto Astronômico e Geofísico da USP: Memória sobre sua Formação e Evolução. São Paulo, EDUSP, 2005, 184p.

SÃO PAULO ganha novo espaço para a ciência. Agenda CNPq, n. 049, p. 5-7, jan./fev. 1987 (informativo do CNPq, ano VIII).

SAYEGH, Simone. Estação Natureza São Paulo. Brasil Arquitetura e Apiacás Arquitetos. Revista AU, n. 184, p. 36-41, jul. 2009.

SCHAUBLE, L.; BARTLETT, C. Constructing a science gallery for children and families: the role of research in an innovative design process. Science Education, n. 81, p. 781-793, 1997.

SCHEINER, Tereza Cristina. Políticas e diretrizes da Museologia e do patrimônio na atualidade. In: SEMINÁRIO INTERNACIONAL "MUSEUS, CIÊNCIA E TECNOLOGIA", 2006, Rio de Janeiro. Livro... BITTENCOURT, José Neves; BENCHETRIT, Sarah Fassa; GRANATO, Marcus (orgs.). Rio de Janeiro, Museu Histórico Nacional, 2007. p. 31-48.

SCHWANTES, Lavínia. Educação e Lazer: a produtividade do Museu de Ciência e Tecnologia da PUCRS. Porto Alegre, 2002, 162p. Dissertação (Mestrado). Faculdade de Educação, Universidade Federal do Rio Grande do Sul.

SERAPIÃO, Fernando. O lugar da arquitetura no agitado caldeirão cultural pernambucano. Projetos em Recife e Olinda mostram vitalidade. Revista Projeto Design, n. 328, p. 40-41, jun. 2007. 
SERREL, B. Introduction. In: What Research Says about Learning in Science Museums. Washington, ASTC, 1990, p. ii-iv.

SILVA, Vânia. Cafeteria da Estação Ciência. UNA Arquitetos. São Paulo, SP. Revista AU, n. 184, p. 42-47, jul. 2009.

SILVER, H. Reconceptualizing social disadvantage: Three paradigms of social exclusion. In: G. Rodgers, C. Gore and J. B. Figueiredo, (eds) Social Exclusion: Rhetoric, Reality, Responses. Geneva, International Institute for Labour Studies, 1995.

SIQUEIRA, Denise da Costa Oliveira. Televisão e divulgação científica. Revista Comciência, n. 100, 2008. Comemorativa. Disponível em <http: //www. comciencia. br/comciencia/ handler. php?section $=8 \&$ edicao $=37 \& i d=444$ >. Acesso em: 18 jul. 2010.

SIREFMAN, Susanna. Polshek-Designed Planetarium Opens. Architecture, v. 89, n. 3, p. 42, mar. 2000.

SMITH, J. K. Methods of Measuring Learning. In: Association of Science Technology Centers - ASTC. What Research Says about Learning in Science Museums. Washington, ASTC, 1990, p. 16-18.

SOARES, Pedro Paulo. Comentários (A museografia / expografia nos domínios da ciência). In: VALENTE, Maria Esther Alvarez (org.). Museus de Ciência e Tecnologia: interpretações e ações dirigidas ao público. Rio de Janeiro, Editora Museu de Astronomia e Ciências Afins, 2007, p. 59-60.

SOUZA, Daniel Maurício Viana de. Museus de ciência, divulgação científica e informação: reflexões acerca de ideologia e memória. Perspectivas em Ciência da I nformação, v. 14, n. 2, p. 155-168, maio/ago. 2009 
SPALTER, Anne Morgan et al. Interaction in an IVR Museum of Color: Constructivism Meets Virtual Reality. Leonardo, v. 35, n. 1, p. 87-90, 2002.

STOCKLMAYER, Susan M. Interactive Exhibits: What are Visitors Really Doing? In: SEMINÁRIO INTERNACIONAL “IMPLANTAÇÃO DE CENTROS E MUSEUS DE CIÊNCIA", Rio de Janeiro, 1999. Disponível em <http://www.casadaciencia.ufrj.br/Publicacoes/Artigos/Seminario/Index.htm>. Acesso em: 7 abr. 2009.

STUDART, Denise Coelho. O público de famílias em Museus de Ciências. In: MARANDINO, M; ALMEIDA, A. M., VALENTE, M. E. A. Museu: lugar do público. 1aㅗ ed. Rio de Janeiro: FAPESP / Editora Fiocruz, 2009, p. 95-120.

STUDART, Denise Coelho. Aparatos interativos e o público infantil em museus: características e abordagens. In: MASSARANI, Luisa (org.). O pequeno cientista amador: a divulgação científica e o público infantil. Rio de Janeiro: Vieira \& Lent: UFRJ, Casa da Ciência, FIOCRUZ, 2005, p. 65-76.

STUDART, Denise C. Famílias, Exposições Interativas, E Ambientes Motivadores Em Museus: O Que Dizem As Pesquisas? In: Avaliação e estudos de públicos no Museu da Vida. Rio de Janeiro: Museu da Vida, 2003, p. 33-42. Disponível em: <http://www.museudavida.fiocruz.br/media/Cadernos-do-Museu-da-Vida2003.pdf>. Acesso em: 16 jul. 2010.

THE COUNCIL for Museums, Archives and Libraries. Segurança de Museus. São Paulo, EDUSP, Fundação Vitae, 2003, 60p. 4 v. Série Museologia: roteiros práticos.

THE COUNCIL for Museums, Archives and Libraries. Acessibilidade. São Paulo, EDUSP, Fundação Vitae, 2005, 120p., 8v. Série Museologia: roteiros práticos. 
TOLEDO, Benedito L. Uma Reflexão sobre o Patrimônio Histórico Cultural do IAG no Parque Estadual das Fontes do Ipiranga - PEFI. In: A USP no PEFI - Subsídios para o estudo de sua utilização pós-mudança do IAG para a CUASO, 1999, Vol. I.

TOSTES, Vera Lúcia Bottrel. Museus, ciência e tecnologia: Um encontro necessário e permanente. In: SEMINÁRIO INTERNACIONAL "MUSEUS, CIÊNCIA E TECNOLOGIA", 2006, Rio de Janeiro. Livro... BITTENCOURT, José Neves; BENCHETRIT, Sarah Fassa; GRANATO, Marcus (orgs.). Rio de Janeiro: Museu Histórico Nacional, 2007, p. 7-10.

TOY, M. Renzo Piano Building Workshop, NewMetropolis, Amsterdam, The Netherlands. Architectural Design, v. 67, n. 11/12, p. II-V, nov./dec. 1997.

TSCHUMI, Bernard. Event-Cities. Cambridge / London, The MIT Press, 2000, v. 2.

TSCHUMI, Bernard. Event-Cities. Concept vs Context vs Content. Cambridge / London, The MIT Press, 2005, v. 3.

VALENTE, Luciano. A ciência sexy da TV. Revista Comciência, n. 100, 2008. $\begin{array}{llll}\text { Comemorativa. } & \text { Disponível < }\end{array}$ http: //www. comciencia. br/comciencia/handler. php? section=8\&edicao $=37 \& i d=448>$ Acesso em: 18 jul. 2010.

VALENTE, Maria Esther Alvarez. ICOM / CIMUSET. In: Museus de Ciência e Tecnologia: interpretações e ações dirigidas ao público. Rio de Janeiro: Editora Museu de Astronomia e Ciências Afins, 2007, p. 149-151 (Apêndice).

VALENTE, M. E.; CAZELLI, S.; ALVES, F. Museus, ciência e educação: novos desafios. História, Ciências, Saúde - Manguinhos, Rio de Janeiro, v. 12, p. 183203, 2005. Suplemento. 
VAN PRAET, M.; DAVALLON, J.; JACOBI, D. Três olhares de além-mar: o museu como espaço de divulgação da ciência. Entrevistas concedidas a Luciana Sepúlveda Koptcke e Luisa Massarani. História, Ciências, Saúde - Manguinhos, v. 12 (suplemento), p. 349-64, 2005.

VIDLER, Anthony. Toward a Theory of the Architectural Program. October, v. 106, p. 59-74, Fall, 2003.

VIDLER, Anthony. A terceira tipologia. In: NESBITT, Kate (org.). Uma Nova Agenda para a Arquitetura. São Paulo, Cosac Naify, 2006, p. 285-289.

WAGENSBERG, Jorge. Museu pra criança ver (e sentir, tocar, ouvir, cheirar e conversar). In: MASSARANI, Luisa (editora). Ciência e criança: a divulgação científica para o público infanto-juvenil. Rio de Janeiro: Museu da Vida / Casa de Oswaldo Cruz / Fiocruz, 2008, p. 66-71.

WAGENSBERG, Jorge. O Museu "Total”, uma Ferramenta para a Mudança Social. In: CONGRESSO MUNDIAL DE CENTROS DE CIÊNCIA, 4, 2005a, Rio de Janeiro. Disponível em http://www.fiocruz.br/museudavida_novo/4scwc/Texto\%20Provocativo\%20\%20J orge\%20Wagensberg.pdf>. Acesso em: 18 jul. 2010.

WAGENSBERG, Jorge. Museu de ciência: arena de ciências. 2005b. Entrevista concedida a Cecília Cavalcanti / Espaço Ciência Viva. Disponível em <http://www.cienciaviva.org.br/arquivo/entrevistas/pages/ent004.htm>. Acesso em: 28 jun. 2010.

WAGENSBERG, Jorge. Museus devem divulgar ciência com emoção. Entrevista concedida a Germana Barata. Ciência e Cultura, São Paulo, v. 55, n. 2, p. 16-17, abr. / jun. 2003. 
WALKER, A. C. (ed.). Britain Divided: The growth of social exclusion in the 1980s and 1990s. London, Child Poverty Action Group, 1997.

WAISMAN, Marina. Tipología. In:

El Interior de la Historia. Historiografía Arquitectónica para uso de Latinoamericanos. Bogotá, Escala, 1990, p. 74-86.

WELLINGTON, Jerry. Formal and informal learning in science: the role of the interactive science centres. Physics Education, n. 25, p. 247-252, 1990.

WITSCHEY, Walter et al. Museums in Transition: Emerging Technologies as Tools for Free-Choice Learning. Gyroscope, Inc., 2006.

ZEVI, Bruno. Saber ver a arquitetura. 3a ed. São Paulo, Martins Fontes, 1992, $276 p$

\section{HOMEPAGES}

AMERICAN Museum of Natural History: <http://www.amnh.org/about/>. Acesso em: 4 abr. 2010

ARCOWEB: <http://www.arcoweb.com.br/arquitetura/arquitetura480.asp>. Acesso em: 14 dez. 2007.

A VIEW on cities: <http://www.aviewoncities.com/montreal/biosphere.htm>. Acesso em: 4 dez. 2010.

CARNEGIE

Science

Center:

<www.carnegiesciencecenter.org/default.aspx?pageld=165>. Acesso em: 25 out. 2010

CITÉ des Sciences et l'Industrie: <universcience.fr>. Acesso em: 04 abr. 2010. 
COSMOCAIXA Barcelona:

<http://obrasocial.lacaixa.es/nuestroscentros/cosmocaixabarcelona/elmuseo_es.ht ml>. Acesso em: 04 dez. 2010.

ESPAÇO Ciência: <http://www.espacociencia.pe.gov.br>. Acesso em: 17 fev. 2011.

ESTAÇÃO Ciência: <http://www.eciencia.usp.br/>. Acesso em: 15 nov. 2007.

ESTAÇÕES Ferroviárias do Brasil: <http://www.estacoesferroviarias.com.br/l/lapasor.htm>. Acesso em: 14 dez. 2007.

GONZALO Mardones Viviani - Homepage do arquiteto. <http://www.gonzalomardonesv.cl/v4/gal2.php?tipo=52>. Acesso em: 17 nov. 2010.

GOVERNO do Estado de São Paulo - Portal de serviços: <http://www.cidadao.sp.gov.br/servicos_final.php?cod_servico=1387>. Acesso em: 14 dez. 2007.

ICOM - International Council of Museums: <http://icom. museum/>. Acesso em: 16 jun. 2010.

JORDI Garcés - Homepage do arquiteto:

<http://www.jordigarces.com/obra.php?id=81\#>. Acesso em: 22 nov. 2010.

NÚCLEO José Reis (ECA-USP): <http://www.eca.usp.br/nucleos/njr/biogr.htm>. Acesso em: 03 dez. 2007.

PALAIS de la Découverte: <http://www.palais-decouverte.fr/index. php?id=339>. Acesso em 17 fev. 2011.

SAMPAART: <http://www.sampa.art.br/cidade/mercadolapa/>. Acesso em: 14 dez. 2007. 
WIKIPEDIA: <http://en.wikipedia.org/wiki/Trylon_and_Perisphere>. Acesso em: 15 dez. 2010. 